Universidade de Aveiro

Ano 2016
Departamento de Línguas e Culturas (DLC)

Departamento de Ciências da Comunicação (DCC)
Kleber José dos Santos
O "clownear" enquanto experiência lúdico-criativa potencializadora da vida na velhice

The "clownear" as a recreational and creative experience potentiator of life in old age

El "clownear" como experiencia lúdico-creativa potenciadora de la vida en la vejez 


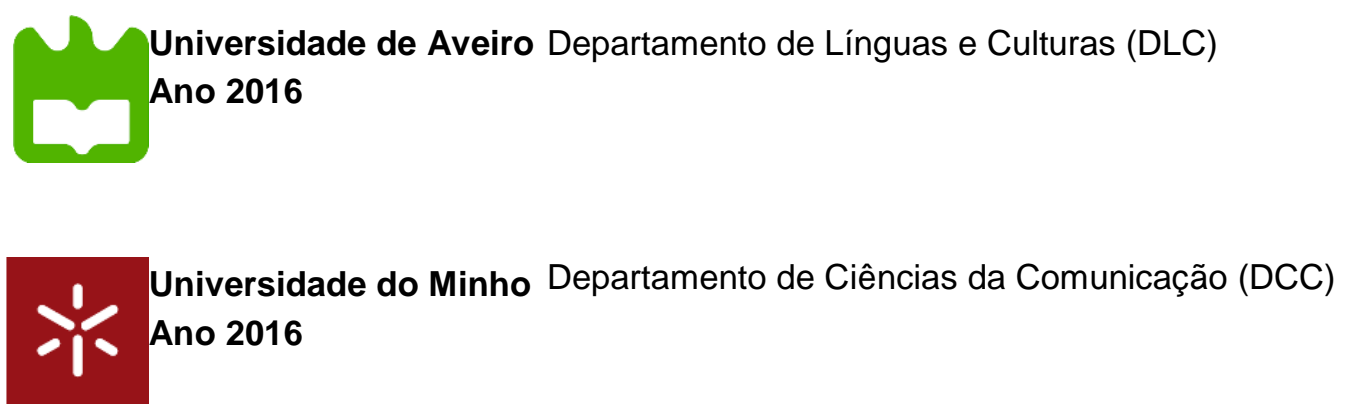

Kleber O "clownear" enquanto experiência lúdico-criativa
potencializadora da vida na velhice José dos Santos

Tese apresentada à Universidade de Aveiro para cumprimento dos requisitos necessários à obtenção do grau de Doutor em Estudos Culturais, realizada sob a orientação científica da Doutora Gillian Grace Owen Moreira, Professora Auxiliar da Universidade de Aveiro (UA) e coorientação do Doutor José Clerton de Oliveira Martins, Professor Titular da Universidade de Fortaleza (UNIFOR), Brasil.

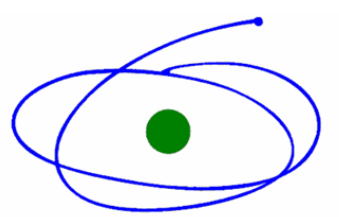

C A P E S 
Dedico este trabalho à minha avó Josepha Anna dos Santos (in memorian)

Pudera eu, mais uma vez, sentir aquelas mãos

facetadas de brandura e amabilidade.

Minha memória guarda felizes momentos.

Kleber Santos 


\section{O júri}

Presidente

Vogais

Prof. Doutora Maria Jesus Monteagudo Sanches

Professora Contratada, Universidade de Deusto, Espanha

Prof. Doutora Jenny Gil Sousa

Equiparada a Assistente do $2^{\circ}$ Triênio, Instituto Politécnico de Leiria

Prof. Doutora Emília Rodrigues Araújo

Professora Auxiliar, Instituto de Ciências Sociais, Universidade do Minho

Prof. Doutor José Clerton de Oliveira Martins

Professor Titular, Universidade de Fortaleza, Brasil (coorientador)

Prof. Doutora Maria da Piedade Moreira Brandão

Professora Adjunta, Universidade de Aveiro

Prof. Doutora Maria Manuel Rocha Teixeira Baptista

Professora Auxiliar com Agregação, Universidade de Aveiro

Prof. Doutora Gillian Grace Owen Moreira

Professora Auxiliar, Universidade de Aveiro (orientadora) 


\section{Agradecimentos}

Um especial agradecimento a minha família, pelas orações, pelo desvelo e por todos os esforços prestados, com particular atenção minha mãe Vicentina Santos e minha tia Irene Tolentino, meus dois "anjos da guarda".

Um agradecimento ao meu amigo Caio Di Palma, pela amizade, pelo companheirismo, pela ajuda, pelos estímulos nas alturas de desânimo e pela partilha de bons momentos. A Biblioteca Almeida Garrett, nos jardins do Palácio de Cristal, foi a nossa segunda casa.

Agradeço à direção do Centro de Convívio para Idosos do Bonfim (CCIB), pela abertura, pela acolhida, pela confiança e pelo apoio facultado para a realização da minha pesquisa empírica.

Minha sincera gratidão às participantes do programa Humor e Bem-estar na Velhice, que prestaram uma contribuição fundamental para a realização da minha pesquisa. A todas o meu muito obrigado, pela disponibilidade, pela cooperação e pelo carinho.

Expresso a minha gratidão aos professores Dra. Gillian Grace Owen Moreira e Dr. José Clerton de Oliveira Martins, pela orientação deste estudo. Obrigado pela disponibilidade, pelas sugestões, pelas críticas, pelas palavras de incentivo, pela confiança e pela amizade.

Agradeço à Coordenação de Aperfeiçoamento de Pessoal de Nível Superior CAPES, pela concessão da bolsa de estudos a mim concedida para a realização desta investigação. 


\section{Palavras-chave}

Resumo
Velhice, idoso, ócio, bem-estar, clown.
Se a velhice for percebida como mais uma etapa do desenvolvimento humano, que pode ser bem aproveitada, vivida com autonomia, com independência e de forma bem criativa, os indivíduos sentir-se-ão incentivados a percorrer novos caminhos e a buscar novos horizontes, novos objetivos, novos desafios, novos interesses e novas experiências que viessem conferir sentido à sua existência. A velhice passou a significar hoje o momento propício para a busca de conhecimento, para a busca de lazer como fonte de prazer, para a criação de novos hábitos, novas habilidades, hobbies e práticas de múltiplas atividades físicas e culturais, enquanto vivências autorrealizadoras e autoconscientizadoras. Mais a mais, a participação em atividades de caráter recreativo, esportivo, social e cultural é de fundamental relevância para a adaptabilidade e manutenção do bem-estar psicofísico e social do indivíduo, haja vista que estas atividades são determinantes para se garantir a satisfação, o otimismo e o entusiasmo nos anos futuros, contrariando todo o senso de exclusão e de inatividade. O que não pode acontecer é o indivíduo carregar consigo o fardo de uma vida atrelada à ausência de sentido.

Aquilo que se procurou constituir como o cerne desta investigação verificar de que forma um processo de criação do clown aplicado com idosos pode possibilitar bem-estar e vida com qualidade - fundamentou-se na efetivação do programa interventivo intitulado Humor e Bem-estar na Velhice, onde pesquisa e ação foram reunidas a partir da integração de processos de planejamento, ação, observação e reflexão. O nosso desafio consistiu em possibilitarmos aos sujeitos implicados na pesquisa um espaço de inclusão, de motivação, de criação, de diversão, de conhecimento, de reflexão e de humanização, como também um espaço/tempo de retomada e recriação de valores essenciais e preditivos para uma velhice bem-sucedida, como a liberdade, a autonomia, a autoaceitação, a autoestima, o autoconhecimento, a autoexpressão e a autorrealização, onde os componentes psicofísicos, sociais e culturais abrangem todos os domínios de satisfação plena e de realização pessoal. Valores estes considerados critérios inquestionáveis para se garantir um grau elevado de disposição emocional, uma individualidade saudável e uma vida social equilibrada, tanto no âmbito pessoal quanto no comunitário, e que apontam para uma forte relação com o ócio e com as reivindicações urgentes e próprias da velhice: longevidade, saúde, eficácia cognitiva, competência social, bem-estar e satisfação com a vida. 
Key-words

Abstract
Old age, old man, idleness, well-being, clown.

If old age is perceived as another stage of human development, which can be well used to advantage, lived with autonomy, independence and in a very creative manner, the individuals will feel themselves encouraged to go new ways and to seek new horizons, new goals, new challenges, new interests and new experiences to give meaning to their existence. Nowadays, old age means the right time to the search for knowledge, for leisure as a source of pleasure, for the creation of new habits, new skills, hobbies and practices of multiple physical and cultural activities, while self-fulfilling and selfconsciousness experiences. Furthermore, the participation in recreational, sporting, social and cultural activities has a fundamental importance for the adaptability and maintenance of individual's psychophysical and social wellbeing, in view that these activities are crucial to ensure the satisfaction, the optimism and the enthusiasm in the coming years, contradicting all sense of exclusion and inactivity. What cannot happen is the individual carries away with him the burden of a life linked to the absence of meaning.

What it was tried to establish as the core of this research - verify how the process of creating the clown applied to elderly may allow well-being and life quality - was based on the realization of the interventional program entitled Humour and Well-being in the Old Age, where research and action were gathered from the integration of planning, action, observation and reflection processes. Our challenge was to enable the subjects involved in the research a space of inclusion, motivation, creation, entertainment, knowledge, reflection and humanization, as well as a space/time of recovery and recreation of core and predictive values for a successful old age, such as the freedom, the autonomy, the self-acceptance, the self-esteem, the self-knowledge, the selfexpression and the self-fulfillment, where the psychophysical, social and cultural components cover all areas of full satisfaction and personal fulfillment. These values are considered unquestionable criteria to ensure a high degree of emotional disposition, a healthy individuality and a balanced social life, both personal and in community, and that point to a strong relationship with the idleness and urgent and own demands from the old age: longevity, health, cognitive efficiency, social competence, well-being and life satisfaction. 
Palabras-clave

Resumen
Vejez, adulto mayor, ocio, bienestar, clown. 


\section{ÍNDICE}

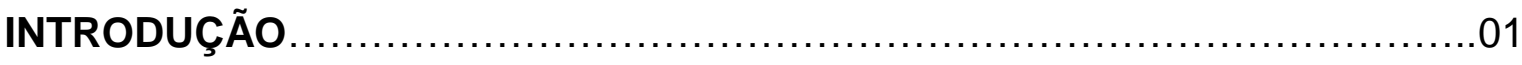

\section{PARTE 1 - ENQUADRAMENTO TEÓRICO}

Capítulo I - Aspectos do envelhecimento e da velhice: seus atributos e suas múltiplas implicações

1.1- O imperativo demográfico: um fenômeno social do séc. $\mathrm{XXI} \ldots \ldots \ldots \ldots \ldots \ldots \ldots . . \ldots 9$

1.2- Envelhecimento ativo: a prevenção enquanto aspecto essencial..............17

1.3- Envelhecimento bem-sucedido: predição de uma vida saudável...............20

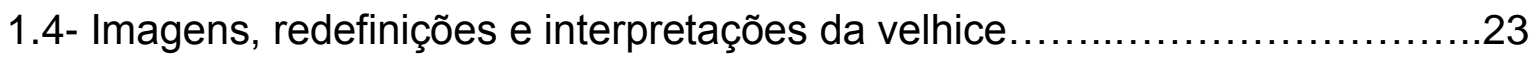

1.5- Idadismo: a construção de uma imagem positiva como aspecto vital..........26

1.6- Velhice: uma representação social associada à reforma.........................30

1.7- O tempo da reforma: um tempo para se viver o ócio.............................36

\section{Capítulo II - O ócio como constituinte da vida}

2.1- Incorporando valores: o ócio para além do senso comum.....................39

2.2- A revalorização do ócio: o resgatar de valores enriquecedores...................41

2.3- Tempo livre: um solo fértil para a expressão do ócio............................45

2.4- O conceito de ócio a partir de uma visão humanista.............................49

2.5- Elementos essenciais para a compreensão do ócio humanista..................52

2.6- A expressão do ócio enquanto vivência grupal e compartilhada.................56

2.7- Ócio lúdico: a diversão como função regenerativa e compensatória..............69

2.8- A ação lúdica: o jogo como atividade necessária à manutenção da vida......61

\section{Capítulo III - Buscando uma aproximação com a linguagem do clown}

3.1- O clown: um sucessor da tipologia da máscara cômica.........................67

3.2- A comicidade e o riso: elementos essenciais da manifestação do clown......70

3.3- O clown: uma caricatura pessoal, única e intransferível..........................75 
3.4- O nariz vermelho: primeiro elemento de composição do clown................77

3.5- Procedimentos e técnicas utilizadas na criação e performance do clown.....79

3.6- O estado de inter-relação: uma ressonância entre corpos.....................82

3.7- O "estado de clown": uma segunda natureza do ator......................84

\section{PARTE 2 - FUNDAMENTAÇÃO E PERCURSO METODOLÓGICO}

\section{Capítulo IV - O projeto investigativo}

4.1- Questões de estudo................................................. 89

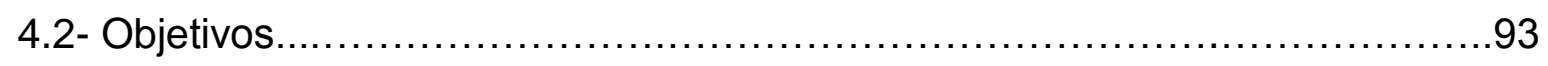

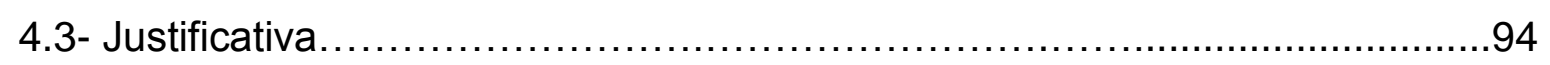

4.4- Domínio de investigação: Estudos Culturais................................ 95

4.5- O método da pesquisa-ação como estratégia de pesquisa....................103

4.6- Técnicas para coleta de dados.......................................... 103

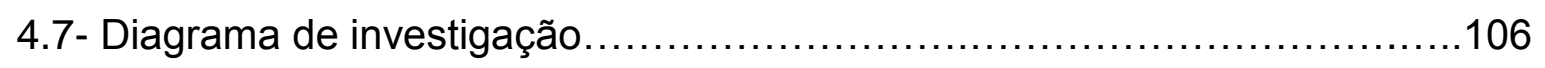

\section{Capítulo V - Corpus empírico}

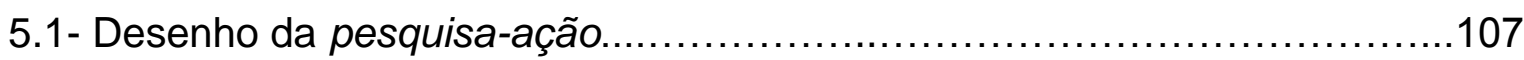

5.2- O programa Humor e Bem-estar na velhice............................108

5.3- Humor e bem-estar: conceitos chave na concepção de saúde................109

5.4- O Centro de Convívio para Idosos do Bonfim (CCIB)......................116

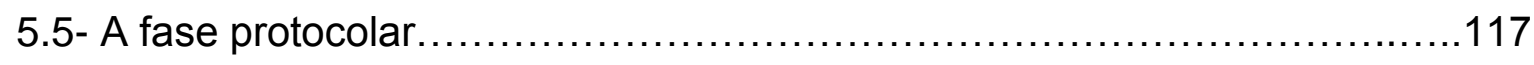

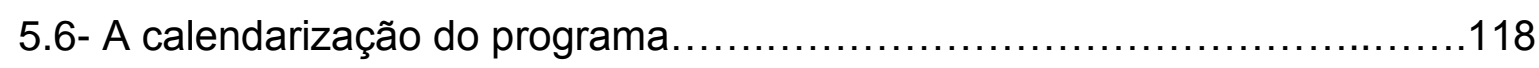

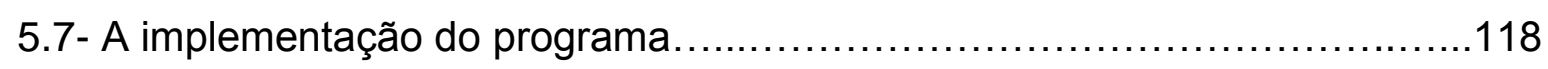

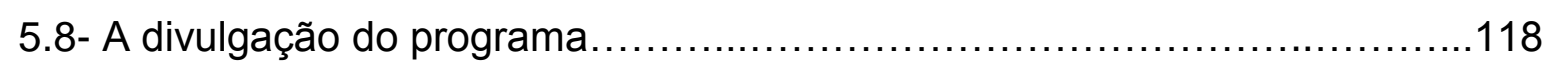

5.9- A inscrição dos interessados........................................120

5.10- Estratégia operacional: princípios estruturais........................120

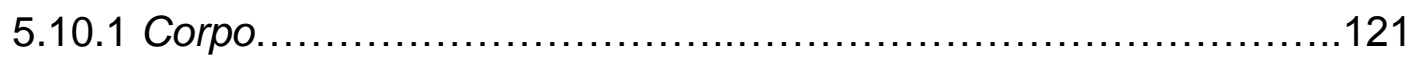

5.10 .2 Expressão corporal.......................................... 121

5.10 .3 Jogos tradicionais............................................ 122

5.10 .4 Jogos teatrais................................................. 122

5.10 .5 Exercícios clássicos de clown...................................125 
5.11- O "Sistema de atividades".

5.12- Buscando uma relação de compreensão.

\section{Capítulo VI - O grupo representativo}

6.1- A entrevista como técnica complementar da pesquisa-ação...................139

6.2- Perfil dos participantes do programa Humor e Bem-estar na Velhice.........142

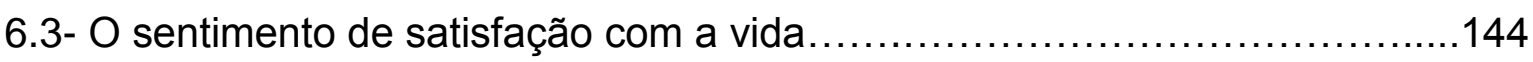

6.4- As ocupações diárias: instrumentais e recreativas..............................158

6.5- A representatividade do clown..............................................166

\section{Capítulo VII - Ocorrência da pesquisa-ação}

7.1- O Processo de Criação do Clown..................................................171

7.2- A linguagem do clown como instrumental para humorizar a vida.............173

7.3- "Jogando a bengala": da quietude para a ação................................176

7.3.1 As atividades de Corpo.................................................178

7.3.2 As atividades de Expressão corporal.................................190

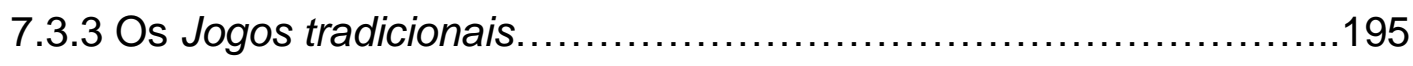

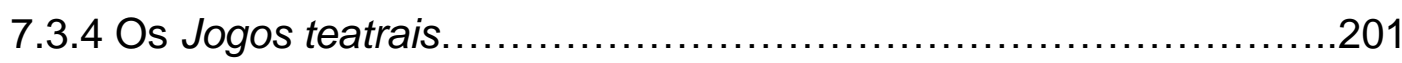

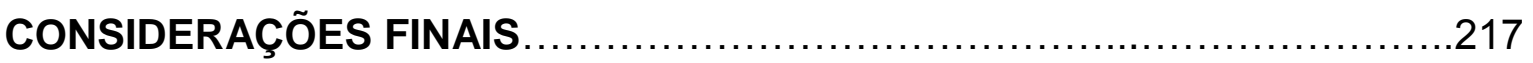

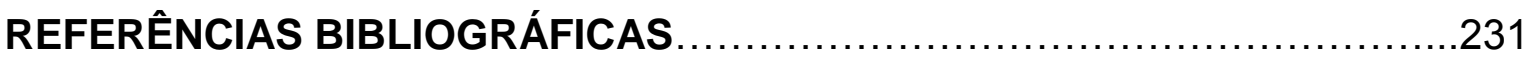

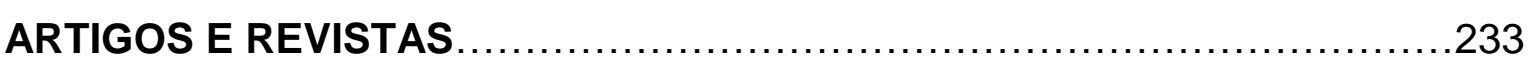

ANEXO 1: Cartaz de divulgação do programa....................................237

ANEXO 2: Termo de Consentimento Livre e Esclarecido - TCLE..................239

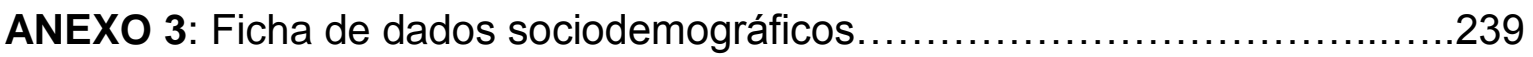

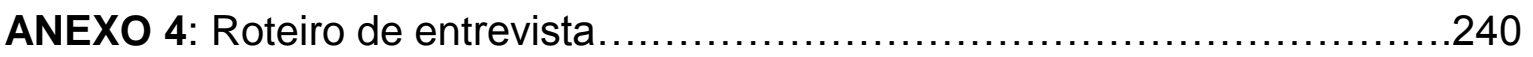




\section{ÍNDICE DE FIGURAS}

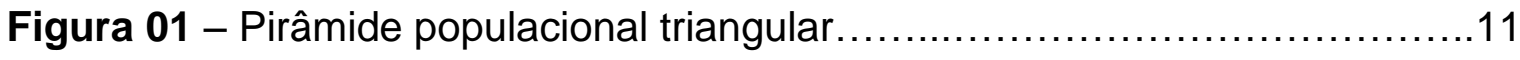

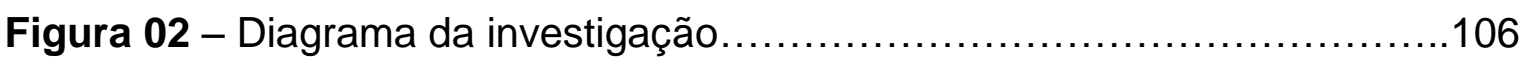

Figura 03 - Plano de ação............................................. 107 


\section{ÍNDICE DE QUADROS}

Quadro 5.1 - Calendarização global.......................................118

Quadro 5.2 - Conteúdo programático..................................120

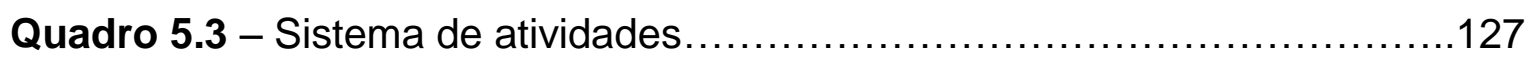

Quadro 6.4 - Caracterização do grupo...................................... 143

Quadro 6.5 - Satisfação com a vida na velhice............................145

Quadro 6.6 - Atividades domiciliares....................................... 163

Quadro 6.7 - Atividades recreativas..................................... 165

Quadro 7.8 - Quadro de frequência....................................173

Quadro 7.9 - Definição de clown......................................... 175 


\section{ÍNDICE DE TABELAS}

Tabela 01 - Países com mais de 10 milhões de habitantes (em 2002) e com maior proporção de pessoas acima de 60 anos.....................................12

Tabela 02 - Número absoluto de pessoas (em milhões) acima de 60 anos em países com população total perto ou acima de 100 milhões (em 2002) 


\section{ÍNDICE DE IMAGENS}

Imagem 01 - Auto de Natal Circense...................................... 03

Imagem 02 - Palhaço Torresmo........................................ 77

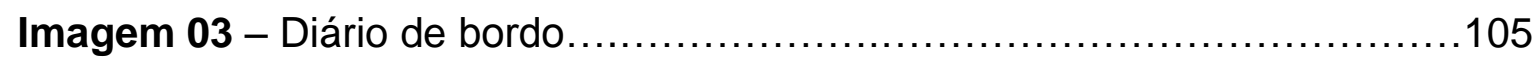

Imagem 04 - Cartaz de divulgação do programa............................119

Imagem 05 - Massagem facial....................................... 181

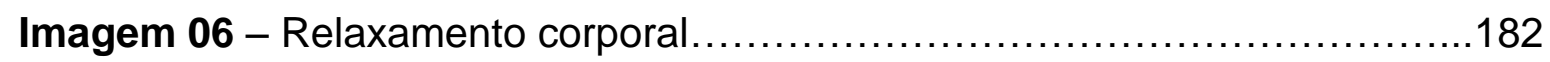

Imagem 07 - Exercício de integração postural.............................186

Imagem 08 - Aquecimento da articulação do pescoço.........................188

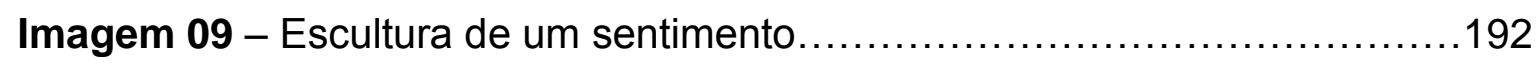

Imagem 10 - Relação com objetos ...................................... 193

Imagem 11 - Expressão de sentimentos...................................194

Imagem 12 - Jogo do "inventar estórias" ................................196

Imagem 13 - Jogo das palmas ........................................ 198

Imagem 14 - Jogo teatral ..................................................

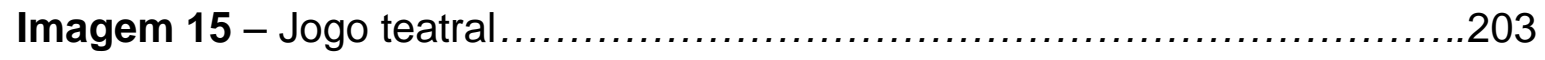

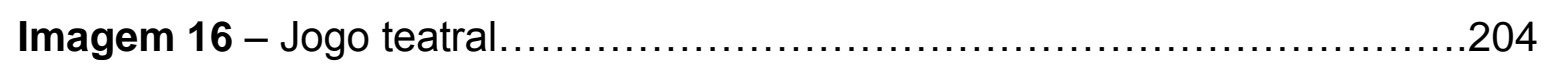

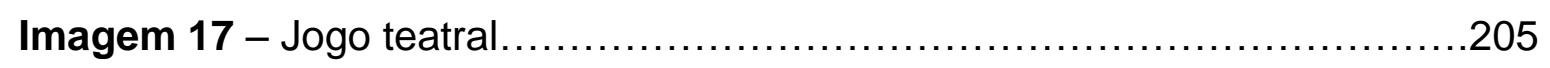

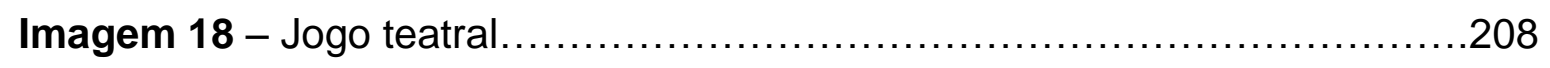

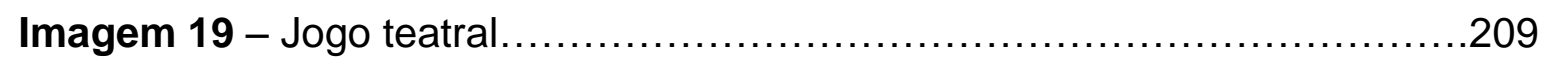

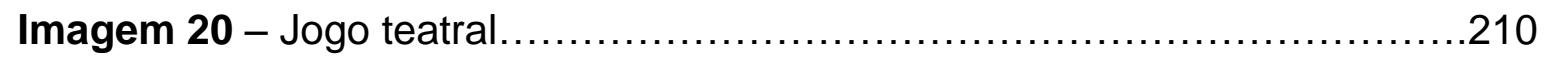

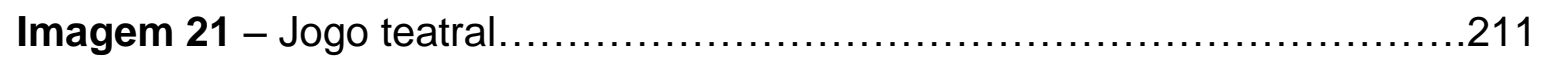

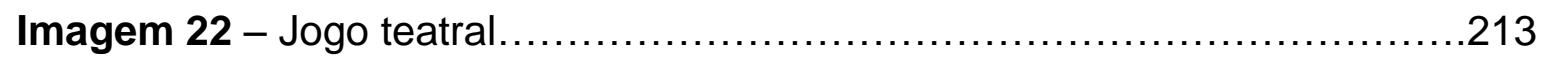

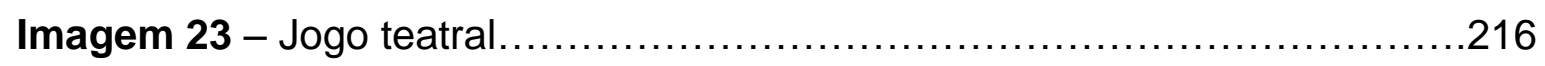




\section{LISTA DE SIGLAS}
AVD Atividades de Vida Diária
BEP Bem-Estar Psicológico
BES Bem-Estar Subjetivo
CCCS Centre for Contemporary Cultural Studies
CCIB Centro de Convívio para Idosos do Bonfim
CFP Conselho Federal de Psicologia
CNDI Conselho Nacional dos Direitos do Idoso
EC Estudos Culturais
INE Instituto Nacional de Estatística
Opas Organização Pan-Americana da Saúde
OMS Organização Mundial da Saúde
ONU Organização das Nações Unidas
TCLE Termo de Consentimento Livre e Esclarecido
WLRA World Leisure and Recreation Association 


\title{
INTRODUÇÃO
}

Reinauguração

\author{
Nossa idade - velho ou moço - pouco importa. \\ Importa é nos sentirmos vivos \\ e alvoroçados mais uma vez, e revestidos de beleza, a \\ exata beleza que vem dos gestos espontâneos \\ e do profundo instinto de subsistir \\ enquanto as coisas em redor se derretem e somem \\ como nuvens errantes no universo estável.
}

Carlos Drummond de Andrade

Neste século XXI, tendo em conta o aumento da esperança média de vida, a velhice, enquanto categoria identitária, passou a ser vista como mais uma etapa do desenvolvimento humano e como um acontecimento positivo para todas as sociedades e para os próprios indivíduos. Se envelhecer, até então, era sinônimo de decadência física e invalidez, onde imperavam a inatividade, a solidão e o isolamento afetivo, hoje o envelhecimento ganhou outros atributos, tais como: bem-sucedido e ativo. Termos que, segundo Côrte (2009, p. 56), "incluem a atividade, o ócio e a questão da continuidade e da vivência no próprio ambiente social. Termos que nos permite entender essa etapa da vida, a da velhice, de uma maneira diversa e singular". A fase da velhice passou a ser percebida hoje como o momento propício para a busca de conhecimento, para a busca de lazer como fonte de prazer, para a criação de novos hábitos, novos hobbies, novas habilidades e práticas de múltiplas atividades, enquanto vivências autorrealizadoras, autoconscientizadoras e autotransformadoras. Tal expectativa vem ganhando ênfase em todas as áreas das ciências e em todas as sociedades, a partir do momento em que a possibilidade de se envelhecer bem e com qualidade de vida se tornou uma realidade para todos.

De acordo com Manuel Cuenca (2009, p. 243), na contemporaneidade, quando vivemos o fenômeno da longevidade, refletir sobre velhice e qualidade de vida é, de certo modo, "refletir sobre uma população que deve encontrar uma forma de realização no ócio, ou, em todo caso, sobre um tempo que é socialmente considerado como tempo de ócio". Segundo o referido autor, na fase da velhice, se comparada às outras fases da vida, o ócio irá adquirir uma 
importância ainda maior, visto que vivenciar experiências verdadeiramente satisfatórias e em maior profundidade pode ajudar o indivíduo a perceber a vida como algo positivo de finalidade e sentido, a enfrentar com mais otimismo a sua nova situação social, a assumir outras atitudes perante a vida e a exercer o papel de protagonista da sua própria existência.

Diferentemente do entendimento geral atribuído ao termo, Cuenca (2009) compreende o ócio como ocupação desejosa, prazerosa, gratificante, de livre escolha e realizada sem nenhuma obrigatoriedade. Ócio é toda e qualquer ocupação relacionada com o mundo da subjetividade, da criatividade, da emotividade, da contemplação, do conhecimento e da reflexão. Segundo o autor, falar de ócio é falar de sentido de vida, de valores essenciais, de uma experiência integral, necessária e enriquecedora da natureza humana, pautada no sentimento de liberdade, de satisfação e de felicidade. Falar de ócio é falar de desenvolvimento psicofísico e enriquecimento intelectual, cultural e espiritual. Falar de ócio é falar também de autoexpressão, de autoconhecimento, de autorrealização, de autoestima, de saúde, bem-estar e qualidade de vida.

Como em qualquer outra fase da vida, na velhice também é fundamental que $\mathrm{o}$ indivíduo busque ocupações, atividades e experiências que confiram sentido à sua existência, com o intuito de aumentar a sua capacidade de viver bem e feliz. O que não pode acontecer é o indivíduo carregar consigo o fardo de uma vida atrelada à ausência de sentido, à inatividade e à solidão (Cuenca, 2009). De acordo com Fonseca (2004), nesta fase da vida as novas possibilidades de comunicação, de ampliação cultural, de participação grupal e de lazer deverão ser colocadas em primeiro plano e ganhar um papel de relevo no cotidiano do indivíduo. As atividades de caráter social, político, cultural, esportivo, recreativo e voluntariado serão de fundamental relevância para a sua adaptabilidade, além de determinantes para se garantir a satisfação, o otimismo e o entusiasmo nos anos futuros, contrariando todo o sentido de exclusão e inatividade.

Enquanto encenador eu tive a oportunidade de agregar ao elenco do espetáculo Auto de Natal Circence um grupo de aproximadamente 30 (trinta) idosos, todos eles integrantes da atividade "Coral de Seresta Viva Voz", oferecida pelo Conservatório Estadual de Música Pe. José Maria Xavier, de São João del Rei, Minas Gerais/ Brasil. 
No decorrer do processo de montagem os idosos foram levados a acompanhar de perto o trabalho dos atores, como também a ornamentar suas próprias indumentárias, aplicando bordados, fitas, rendas, fuxicos, botões, pedras e flores, dando a elas a representação figurada da Folia dos Santos Reis e Congada, cujas manifestações trazem no seu bojo uma grande riqueza visual e estética. Enquanto parte integrante do espetáculo os idosos, além de conduzirem - Cortejo Festivo, intervinham nas cenas como representantes do povo, dialogando com os atores/clowns e entoando cânticos folclóricos e natalinos, formando um coro glamoroso de vozes. Esta experiência me levou a perceber o quanto o fazer teatral contribuiu para o bem-estar e para a autoestima daqueles idosos.

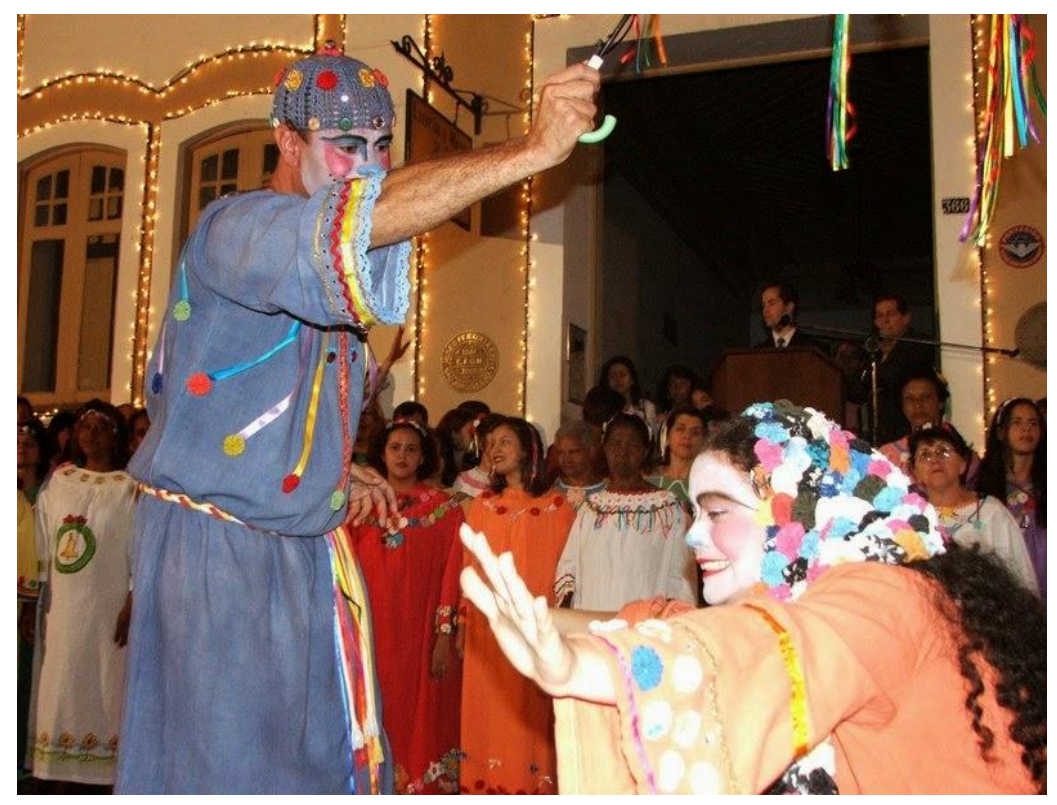

Imagem 01: Auto de Natal Circense

A partir do vivenciado e do referencial teórico levantamos as seguintes questões de investigação: A aplicação de um Processo de Criação do Clown num contexto social atribuído à velhice pode possibilitar bem-estar e potencializar a vida? As atividades que atravessam este processo podem ser percebidas como possibilidades de experiências de ócio?

Estas duas questões deram origem à seguinte hipótese: o desafio de testarmos um Processo de Criação do Clown com idosos pode resultar na construção de uma nova consciência que busque quebrar com os tabus e mitos 
erigidos sobre a velhice, a fim de superarmos as imagens negativas, discriminatórias e preconceituosas que ainda são construídas socialmente acerca da pessoa idosa.

O nosso desafio consiste em criarmos um espaço de inclusão, de motivação, de criação, de diversão, de conhecimento, de reflexão e de humanização, como também um espaço/tempo de retomada e recriação de valores considerados essenciais e preditivos para uma velhice bem-sucedida, como a liberdade, a autonomia, a autoaceitação, a autoestima, o autoconhecimento, a autoexpressão e a autorrealização. Valores estes, considerados critérios inquestionáveis para se garantir um grau elevado de disposição emocional, uma individualidade saudável e uma vida social equilibrada, tanto no âmbito pessoal quanto no comunitário, e que apontam para uma forte relação com o ócio e com as reivindicações urgentes e próprias da velhice.

De acordo com Burnier (2001) e Ferracini (2003), todo processo de criação do clown é atravessado por atividades diversas, constituídas por procedimentos específicos de relação com a alteridade. Este processo vai implicar um estado de abertura, de liberdade, de generosidade e de vulnerabilidade, extremamente necessários para se atingir a pureza, a ingenuidade, a fragilidade, a espontaneidade e a alegria de um clown, como também o confronto entre a "máscara" que esconde a pessoa do sujeito e a essência do seu próprio ser. Segundo os referidos autores, um clown não se representa, ele "é", não se trata de um personagem, mas da exposição da excentricidade do próprio sujeito, ou seja, do seu lado tolo e ridículo de ser tão bem camuflado. O clown é pessoal, único e intransferível. O termo pessoal vai evocar no sujeito o exercício da exposição da sua própria singularidade: refere-se à exposição e dilatação dos seus aspectos ingênuos, puros e humanos; refere-se à criação de uma lógica própria, de maneiras peculiares de agir, pensar e sentir; refere-se à busca da compreensão do seu modo pessoal e específico de jogo e de relação, da produção de si, do [re] inventar-se. Neste processo o que o sujeito experimenta é o emergir de outras formas de ser, estar e fazer até antes não acessadas, além da sensação de que tudo lhe é permitido.

E é com base nesta premissa que situamos a presente tese - $O$ "clownear" enquanto experiência lúdico-criativa potencializadora da vida na velhice - 
desenvolvida no domínio dos Estudos Culturais, e que teve como objetivo: verificar de que forma um Processo de Criação do Clown aplicado com idosos pode possibilitar bem-estar e vida com qualidade.

De acordo com Baptista (2009), a história dos Estudos Culturais, desde a sua gênese, apresenta-se menos como uma disciplina e mais como um domínio intelectual interdisciplinar, onde diferentes disciplinas se interseccionam, sugerindo múltiplas possibilidades de cruzamento. Trata-se de um campo de estudo intrinsecamente paradoxal, que se fundamenta na contestação dos limites socialmente construídos nas mais diversas realidades humanas, buscando solucionar um conjunto de questões sócio/culturais através do uso de paradigmas teóricos, metodológicos e estilísticos de causas diversas, propondo a interdisciplinaridade.

Nesta tese, de reflexão interdisciplinar, predominantemente qualitativa e de caráter artístico/social, a pesquisa empírica configurou-se a partir da aplicação do método da pesquisa-ação, que deu forma e sustentação ao programa interventivo intitulado Humor e Bem-estar na Velhice, implementado e efetivado no Centro de Convívio para Idosos do Bonfim (CClB), na cidade do Porto, em Portugal. A escolha desta metodologia deu-se em função da sua orientação prática e flexibilidade, onde pesquisa e ação foram reunidas a partir da integração de processos de Planejamento, Ação, Observação e Reflexão. O âmbito favorável da pesquisa-ação deu-se também por duas razões: primeira, de o investigador ter podido realizar uma ação com princípios e práticas participativas, transformadoras e dialógicas, criando um nexo entre a investigação e a realidade social dos agentes implicados na pesquisa; e segunda, de os agentes terem podido desempenhar um papel ativo na realidade dos contextos observados e dizer algo acerca das suas experiências.

A primeira parte desta tese foi estruturada em 03 (três) capítulos, consagrados ao Enquadramento Teórico, que deram suporte à pesquisa e inseriram o objeto de estudo dentro de um quadro conceitual já existente. No capítulo I - Aspectos do Envelhecimento e da Velhice: seus atributos e suas múltiplas implicações - apresentamos um breve panorama sobre o fenômeno do envelhecimento demográfico global; uma visão dos paradigmas que apontam para um envelhecimento saudável e com qualidade; um entendimento dos conceitos que remetem para as diversas imagens, definições e interpretações 
acerca da velhice; e uma compreensão do processo de transição-adaptação decorrente da passagem para a reforma. No capítulo II - O ócio como constituinte da vida - apresentamos os saberes sobre o significado de ócio produzidos no nível do senso comum; um entendimento sobre o conceito de "tempo livre" enquanto solo fértil para a expressão do ócio; e uma visão compreensível do real significado de ócio (da sua importância, do seu sentido, dos seus valores e dos seus benefícios), a partir da concepção de Ócio Humanista. No capítulo III - Buscando uma aproximação com a linguagem do clown - apresentamos um breve estudo sobre a arte do clown, para o entendimento de uma proposta que utilizou a sua linguagem como um dos elementos centrais de investigação: sua origem; sua manifestação; sua comicidade; sua composição; sua máscara; seu treinamento.

A segunda parte constituiu-se de 04 (quatro) capítulos e está especificamente orientada para o objetivo desta tese. No capítulo IV - O projeto investigativo - apresentamos os pressupostos que fundamentam este estudo e o seu equacionamento metodológico. No capítulo V - Corpus empírico apresentamos a planificação da pesquisa-ação em sua dimensão mais ampla.

No capítulo VI - O grupo representativo - apresentamos o perfil dos agentes implicados na pesquisa e discutimos questões concernentes a eles e à problemática investigada. No capítulo VII - Ocorrência da pesquisa-ação apresentamos a descrição das atividades desenvolvidas no decorrer do programa Humor e Bem-estar na Velhice, como também a inferência e os efeitos resultantes destas atividades, segundo os quais nos foi possível chegar a uma conclusão.

Acreditamos que este estudo é de fundamental relevância para as instâncias produtoras de políticas de envelhecimento, que precisam se preparar para as transformações que começam a ter lugar num cenário de envelhecimento presente e futuro, e que deverão se adequar à essa nova realidade. De acordo com o Conselho Federal de Psicologia do Brasil (CFP) (2009, p.10), face ao fenômeno do envelhecimento demográfico global, "interagir saberes e desenvolver competências para trabalhar de modo interdisciplinar são requisitos mínimos para que os trabalhos produzidos pelas diversas profissões ofereçam respostas eficazes para uma vida digna para os idosos neste futuro próximo". 
PARTE 1

ENQUADRAMENTO

TEÓRICO 


\section{CAPÍTULO I}

\section{ASPECTOS DO ENVELHECIMENTO E DA VELHICE: SEUS ATRIBUTOS E SUAS MÚLTIPLAS IMPLICAÇÕES}

\section{1- O imperativo demográfico: um fenômeno social do séc. $X X I$}

Neste século XXI, com o alcance da longevidade da população, a velhice passou a ser vista como mais uma etapa do desenvolvimento humano e interpretada como um acontecimento positivo para todas as sociedades e para os próprios indivíduos. Todavia, se o envelhecimento da população global representa um triunfo para a humanidade, já que corresponde a uma redução da desigualdade verificada na morbidade e nas taxas de mortalidade, a constatação de uma crescente população de idosos nas próximas décadas não deixa de impor grandes desafios aos governantes, às organizações e à sociedade civil, implicando a responsabilização, a participação e o engajamento de todos. Nesta perspectiva, torna-se urgente buscarmos estratégias para superarmos este novo desafio, pois atrelada à esta conquista existem ainda aspectos que precisam ser desvendados e desmistificados, com o propósito de possibilitarmos a esta população que está envelhecendo uma ótima qualidade de vida, não só do ponto de vista biofisiológico, mas também social e cultural, que são aspectos inteiramente responsáveis pelo bem-estar e pela integralidade do ser humano. De acordo com a Organização Mundial da Saúde (OMS), "em um mundo cada vez mais interligado, a omissão para lidar, de um modo sensato e em qualquer parte do mundo, com o imperativo demográfico e as mudanças rápidas nos padrões de doenças, terá consequências políticas e socioeconômicas em todos os lugares" (Opas, 2005, p. 45).

Do ponto de vista histórico, o aumento da esperança média de vida e o envelhecimento demográfico são fenômenos novos que surgiram nos países desenvolvidos a partir da segunda metade do século XX. Trata-se de uma realidade nova na história das populações e as projeções indicam, com certeza, que a tendência para o envelhecimento da população global é cada vez mais acentuada. As causas da longevidade da população estão associadas aos 
substanciais progressos da ciência e da medicina atingidos no século $\mathrm{XX}$, tanto na área da prevenção como também na área de tratamentos de doenças crônicas, "estabelecendo parâmetros cada vez mais definidos do desenvolvimento humano e conquistando descobertas que se concretizam em tecnologias de tratamento reconhecidamente eficazes e precisas"1 (Minayo \& Coimbra Junior, 2002, p. 20). Além disso, outros aspectos também podem ser considerados, como a acentuada queda da taxa de natalidade, de fertilidade ${ }^{2}$ e os melhores cuidados em relação à saúde, o que resulta na diminuição da proporção de jovens e no aumento da proporção de indivíduos com idade acima de 60 anos, idade esta, padronizada pela Organização das Nações Unidas (ONU) para descrever pessoas mais velhas. Segundo a OMS:

(...) qualquer que seja a idade definida dentro de contextos diferentes, é importante ressaltar que a idade cronológica não é um marcador preciso para as mudanças que acompanham o envelhecimento. Existem variações significativas relacionadas ao estado de saúde, participação e níveis de independência entre pessoas mais velhas que possuem a mesma idade. Aqueles escolhidos por nós para tomar decisões precisam considerar essas variações ao planejarem políticas e programas para suas populações "mais velhas". Fazer vigorar políticas sociais abrangentes baseadas somente na idade cronológica pode ser discriminatório e contraproducente para o bem-estar na velhice. (Opas, 2005, p. 6)

De acordo com a OMS, a notável transição demográfica que se está gerando fará com que, pelos meados do século XXI, as porcentagens da população mundial correspondentes a velhos e jovens sejam praticamente iguais. $\mathrm{Na}$ figura 01 podemos observar que à medida que a proporção de crianças e jovens diminui e a proporção de pessoas acima de 60 anos aumenta a pirâmide populacional triangular de 2005 é substituída por uma disposição muito mais

\footnotetext{
1 É interessante notar que a maioria dos medicamentos mais modernos, por meio dos quais a indústria farmacêutica mais lucra, estão voltados para o 'envelhecimento com qualidade de vida' ou para manter o mito da imortalidade ou da eterna juventude, com base em pesquisas farmacológicas e genéticas de ponta (Minayo \& Coimbra Junior, 2002, p. 20).

2 Estima-se que, até 2025, 120 países terão alcançado taxas de fertilidade total abaixo do nível de reposição (média de fertilidade de 2,1 crianças por mulher). Isso representa um aumento substancial se comparado a dados de 1975, quando apenas 22 países possuíam uma taxa de fertilidade total menor ou igual ao nível de reposição. O número atual é de 70 países (Opas, 2005, p. 9).
} 
cilíndrica em 2050. A diminuição de crianças e jovens e o aumento de idosos corresponde ao que os demógrafos denominam de duplo envelhecimento, tanto na base quanto no topo da pirâmide. $O$ envelhecimento na base da pirâmide acontece quando a porcentagem de jovens começa a decrescer e, em contrapartida, esta mesma base fica substancialmente reduzida quando a porcentagem de idosos no topo começa a crescer, provocando, deste modo, um alargamento na parte superior da pirâmide.

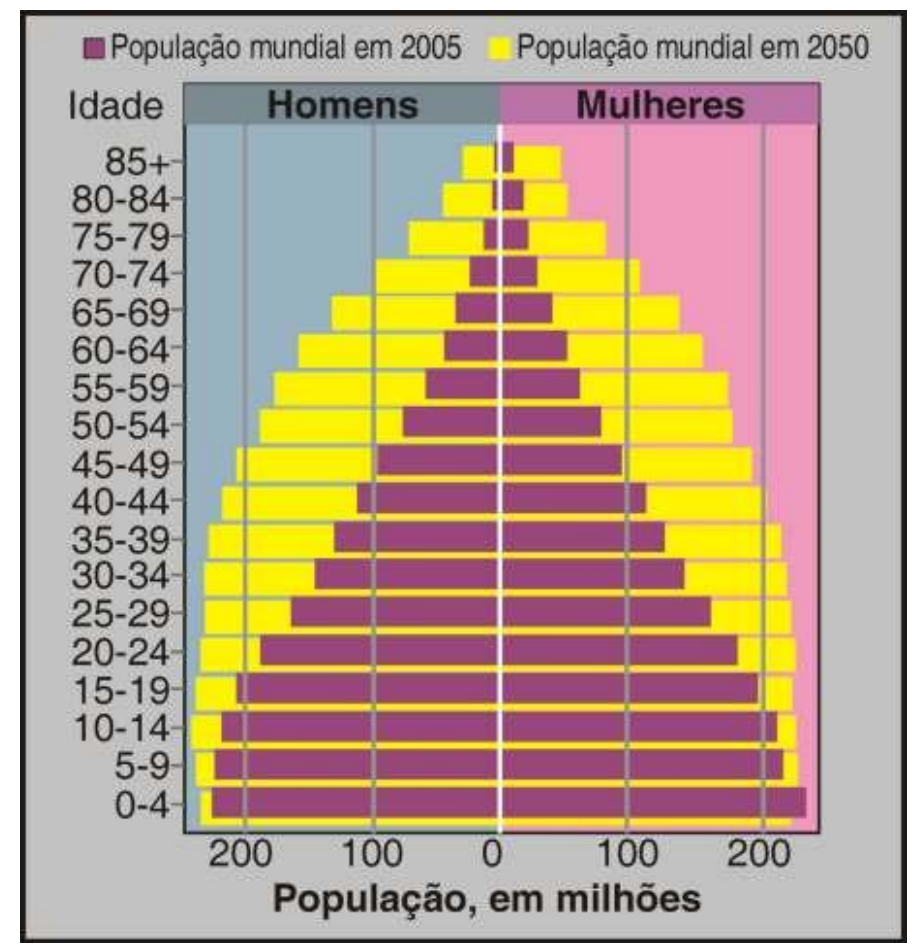

Figura 01: Pirâmide populacional triangular Fonte: Nações Unidas, 2005.

Em alguns países desenvolvidos, como também nos de economias em transição, o número de idosos já supera o de crianças, e as taxas de natalidade caíram muito abaixo do nível de reposição. A ONU alerta que em 2050 a população com mais de 60 anos de idade atingirá a média de $22 \%$ (vinte e dois por cento) da população global, chegando a um número de aproximadamente 02 (dois) bilhões de idosos, sendo $80 \%$ (oitenta por cento) nos países em desenvolvimento. Nota-se, também, que a faixa etária dos 80 anos de idade, se comparada às demais faixas etárias, é o segmento da população que mais crescerá nos próximos anos, nomeadamente a de gênero feminino. 
A análise do envelhecimento da população global é feita sobre a perspectiva de dois grandes grupos. Um destes grupos é constituído pelos países desenvolvidos e o outro pelos países que iniciaram o fenômeno da transição demográfica mais tarde, ou seja, os países em desenvolvimento. Na maioria dos países desenvolvidos o envelhecimento da população se deu num processo progressivo, acompanhado de crescimento sócioeconômico regular durante muitas décadas, já nos países ainda em desenvolvimento o processo de envelhecimento está sendo reduzido a duas ou três décadas, isto é, enquanto sociedades desenvolvidas enriqueceram antes de envelhecerem, em termos sócioeconômicos, os países ainda em desenvolvimento, ao contrário, estão envelhecendo sem terem atingido uma "economia ideal", além de não possuírem uma política mais abrangente voltada para a velhice.

Segundo a ONU (2003), o aumento da longevidade sempre esteve associado a sociedades mais desenvolvidas. Conforme a tabela 01 , as estatísticas indicam que $90 \%$ dos países com população acima de 10 milhões e maior proporção de habitantes idosos está situado na Europa, e até 2025 esta população irá compor aproximadamente $1 / 3$ de países como o Japão, Itália e Alemanha.

\begin{tabular}{|c|c|c|c|}
\hline \multicolumn{4}{|c|}{$\begin{array}{l}\text { Tabela 01: Países com mais de } 10 \text { milhões de habitantes (em 2002) } \\
\text { e com maior proporção de pessoas acima de } 60 \text { anos }\end{array}$} \\
\hline \multicolumn{2}{|c|}{2002} & \multicolumn{2}{|c|}{2025} \\
\hline Itália & $24,5 \%$ & Japão & $35,1 \%$ \\
\hline Japão & $24,3 \%$ & Itália & $34,0 \%$ \\
\hline Alemanha & $24,0 \%$ & Alemanha & $33,2 \%$ \\
\hline Grécia & $23,9 \%$ & Grécia & $31,6 \%$ \\
\hline Bélgica & $22,3 \%$ & Espanha & $31,4 \%$ \\
\hline Espanha & $22,1 \%$ & Bélgica & $31,2 \%$ \\
\hline Portugal & $21,1 \%$ & Reino Unido & $29,4 \%$ \\
\hline Reino Unido & $20,8 \%$ & Países Baixos & $29,4 \%$ \\
\hline Ucrânia & $20,7 \%$ & França & $28,7 \%$ \\
\hline França & $20,5 \%$ & Canadá & $27,9 \%$ \\
\hline
\end{tabular}

Fonte: Nações Unidas, 2001. 
De acordo com a ONU, o envelhecimento da população passará a ser uma questão de importância ainda maior nos países menos desenvolvidos, que envelhecerão muito rapidamente na primeira metade do século XXI. Um fator significante das diferenças demográficas dever-se-á ao fato de estes paises registrarem um acentuado envelhecimento da população nas zonas rurais ${ }^{3}$, ao contrário dos países desenvolvidos, onde grande parte da população envelhecida estará vivendo nas zonas urbanas.

$\mathrm{Na}$ tabela 02, a seguir, podemos observar que até 2025 cerca de $70 \%$ da população de idosos no mundo estará vivendo nos países em desenvolvimento 4 , o que corresponde a um número de aproximadamente 840 milhões de idosos, sendo mais da metade desta população habitante na Ásia.

\begin{tabular}{|c|c|c|c|}
\hline \multicolumn{4}{|c|}{$\begin{array}{l}\text { Tabela 02: Número absoluto de pessoas (em milhões) acima de } 60 \text { anos } \\
\text { de idade em países com população total perto ou acima de } 100 \text { milhões (em } \\
\text { 2002) }\end{array}$} \\
\hline \multicolumn{2}{|l|}{2002} & \multicolumn{2}{|l|}{2025} \\
\hline China & 134,2 & China & 287,5 \\
\hline Índia & 81,0 & Índia & 168,5 \\
\hline Estados Unidos da América & 46,9 & Estados Unidos da América & 86,1 \\
\hline Federação Russa & 26,2 & Indonésia & 35,0 \\
\hline Indonésia & 17,1 & Brasil & 33,4 \\
\hline Brasil & 14,1 & Federação Russa & 32,7 \\
\hline Paquistão & 8,6 & Paquistão & 18,3 \\
\hline México & 7,3 & Bangladesh & 17,7 \\
\hline Bangladesh & 7,2 & México & 17,6 \\
\hline Nigéria & 5,7 & Nigéria & 11,4 \\
\hline
\end{tabular}

Fonte: Nações Unidas, 2001.

\footnotetext{
3 Em muitos países em desenvolvimento e países de economia em transição registra-se acentuado envelhecimento da população das zonas rurais, devido à partida de jovens e adultos. É possível que os idosos tenham que permanecer nas zonas rurais sem contar com o tradicional apoio da família e, inclusive, sem adequados recursos financeiros. As políticas e programas de segurança alimentar e de produção agrícola devem considerar as conseqüências do envelhecimento nas zonas rurais. As mulheres idosas nas zonas rurais são particularmente vulneráveis do ponto de vista econômico, especialmente quando sua função se limita a prática de tarefas não remuneradas e sua própria sobrevivência depende do apoio vindo de outros (ONU, 2003).

4 O rápido envelhecimento nos países em desenvolvimento é acompanhado por mudanças dramáticas nas estruturas e nos papéis da família, assim como nos padrões de trabalho e na migração. A urbanização, a migração de jovens para cidades à procura de trabalho, famílias menores, e mais mulheres tornando-se força de trabalho formal significam que menos pessoas estão disponíveis para cuidar de pessoas mais velhas quando necessário (Opas, 2005, p. 12).
} 
Ao discursar na II Assembléia Mundial sobre o Envelhecimento - realizada em 2002 pela Organização das Nações Unidas (ONU), em Madrid/ Espanha - o então Secretário-geral da ONU, Sr. Kofl Annan, apontou que o mundo passará por alterações demográficas sem precedentes. Segundo o Secretário-geral, tratase de um fenômeno excepcional e com decorrências para cada sociedade, cada instituição e cada pessoa, convertendo-se em tema dominante neste século XXI. O envelhecimento da população já não é apenas um problema do primeiro mundo, é um fenômeno global que suscita problemas comuns, que devem ser solucionados diferentemente de cultura para cultura, já que o processo de envelhecimento acontece de forma distinta, não só de indivíduo para indivíduo e de geração para geração, mas também de sociedade para sociedade. $O$ preocupante é que todos os níveis da sociedade podem ser afetados pelo fenômeno do envelhecimento, que tende a provocar um impacto nas relações sociais, na solidariedade familiar, na equidade entre as gerações e nos estilos de vida, além de exigir importantes ajustamentos econômicos e sociais na maioria dos países. Face a essa realidade, torna-se necessário planejamentos inovadores e políticas mais abrangentes, tanto nos países desenvolvidos como nos países ainda em desenvolvimento. É preciso incentivarmos e apoiarmos as iniciativas interdisciplinares e intersetoriais, sobretudo as políticas voltadas para os países em desenvolvimento, que se defrontam com índices rápidos e sem precedentes da população que está envelhecendo, centradas em equipes pluridisciplinares e em recursos humanos devidamente capacitados, com uma componente de recuperação do envelhecimento global e de acompanhamento, por meio de cuidados contínuos e de longa duração, acessíveis e sensíveis às necessidades mais frequentes de uma população que está envelhecendo. Mediante o Conselho Federal de Psicologia do Brasil (CFP) (2009, p. 10), "interagir saberes e desenvolver competências para trabalhar de modo interdisciplinar são requisitos mínimos para que os trabalhos produzidos pelas diversas profissões ofereçam respostas eficazes para uma vida digna para os idosos neste futuro próximo". 0 fenômeno do envelhecimento demográfico tem desencadeado aberturas temáticas para reflexões sobre o processo de envelhecimento e a necessidade de formulação de planos de ação que possam garantir um envelhecimento saudável e ativo à população, além da segurança e da participação dos mais velhos, com especial atenção aos que apresentam algum tipo de doença, que são fisicamente 
incapacitados ou que vivem com alguma necessidade especial. Preocupada com esta nova realidade a OMS traz à luz as seguintes questões:

Como podemos ajudar pessoas a permanecerem independentes e ativas à medida que envelhecem? Como podemos encorajar a promoção da saúde e as políticas de prevenção, especialmente aquelas direcionadas aos mais velhos? Já que as pessoas estão vivendo por mais tempo, como a qualidade de vida na Terceira Idade pode ser melhorada? Um grande número de pessoas na Terceira Idade causará a falência de nossos sistemas de saúde e de previdência social? Como podemos equilibrar o papel da família e do Estado em termos de assistência àqueles que necessitam de cuidados à medida que envelhecem? Como podemos reconhecer e apoiar o papel importante que as pessoas mais velhas desempenham no cuidado aos outros? (Opas, 2005, p. 7).

Encontrar respostas válidas para estas questões são de fundamental importância para as instâncias produtoras de políticas ou programas de envelhecimento, que precisam se preparar para as transformações que começam a ter lugar num cenário de envelhecimento presente e futuro. Tais políticas deverão ser fundamentadas nos direitos, nas necessidades, nas preferências e habilidades dos mais velhos; deverão reconhecer a perspectiva de curso de vida ${ }^{5}$ como fator relevante para a maneira como o indivíduo envelhece; reconhecer a necessidade de incentivar a solidariedade entre gerações; reconhecer a necessidade de conscientizar as famílias e indivíduos sobre a importância de se levar uma vida equilibrada e saudável e dos cuidados pessoais para consigo próprio. A Opas (2005, p. 18) alerta que "as famílias e os indivíduos precisam se planejar e se preparar para a velhice, e precisam se esforçar pessoalmente para adotar uma postura de práticas saudáveis em todas as fases da vida".

O Plano de Ação Internacional sobre o Envelhecimento/2002, adotado pelos representantes dos governos na II Assembleia Mundial sobre 0 Envelhecimento, exige mudanças de atitudes, de práticas e de políticas em todos os setores e níveis, com o intuito de consolidar as inúmeras possibilidades que

\footnotetext{
5 A noção de curso de vida (ou life-span) refere-se às maneiras como a sociedade atribui significados sociais e pessoais à passagem do tempo biográfico, permitindo a construção social de personalidades e trajetórias de vida, com base numa sequência de transições demarcadas socialmente e diferenciadas por idade (Neri, 1995, p. 30).
} 
oferece o envelhecimento neste século XXI. O objetivo maior deste plano de ação consiste em garantir que a população mundial possa envelhecer com segurança e dignidade, que os idosos possam continuar ativos em suas respectivas sociedades, sem discriminação e em condições de igualdade, como cidadãos com plenos direitos.

Dos vários temas centrais definidos pelo Plano de Ação Internacional sobre o Envelhecimento/2002 podemos destacar: (i) plena realização de todos os direitos humanos e liberdades fundamentais de todos os idosos; (ii) envelhecimento em condições de segurança, o que implica reafirmar o objetivo da eliminação da pobreza na velhice com base os Princípios das Nações Unidas em favor dos idosos; (iii) capacitação de idosos para que participem plena e eficazmente na vida econômica, política e social de suas sociedades, inclusive com trabalho remunerado ou voluntário; (iv) as oportunidades de desenvolvimento, realização pessoal e bem-estar do indivíduo em todo curso de sua vida, inclusive numa idade avançada, por exemplo, mediante a possibilidade de acesso à aprendizagem durante toda a vida e a participação na comunidade, ao tempo que se reconhece que os idosos não constituem um grupo homogêneo; (v) garantia dos direitos econômicos, sociais e culturais dos idosos assim como de seus direitos civis e políticos, e a eliminação de todas as formas de violência e discriminação contra idosos; (vi) compromisso de reafirmar a igualdade dos sexos para as pessoas idosas, entre outras coisas mediante a eliminação da discriminação por motivos de sexo; (vii) reconhecimento da importância decisiva que tem as famílias para o desenvolvimento social e a interdependência, a solidariedade e a reciprocidade entre as gerações; assistência à saúde, apoio e proteção social dos idosos, inclusive os cuidados com a saúde preventiva e de reabilitação; (viii) promoção de associação entre governo, em todos os seus níveis, sociedade civil, setor privado e os próprios idosos no processo de transformar o Plano de Ação em medidas práticas; (ix) utilização das pesquisas e dos conhecimentos científicos e aproveitamento do potencial da tecnologia para considerar, entre outras coisas, as consequências individuais, sociais e sanitárias do envelhecimento, particularmente nos países em desenvolvimento; $(x)$ reconhecimento da situação dos idosos pertencentes a populações indígenas, suas circunstâncias singulares e a necessidade de encontrar meios de terem voz ativa nas decisões que diretamente lhes dizem respeito (ONU, 2003, pp. 30-31). 


\section{2- Envelhecimento ativo: a prevenção enquanto aspecto essencial}

De acordo com a OMS, as sociedades vêm se deparando com uma população cada vez mais envelhecida, cuja expectativa média de vida tende a crescer ainda mais nas próximas décadas. O processo de envelhecimento e suas múltiplas implicações, seja no plano individual, social, cultural ou econômico, vem ganhado espaço no campo da investigação. É notável a mudança de uma abordagem historicamente centralizada nos aspectos genético-biológicos para uma perspectiva que reconhece a velhice como um setor socialmente importante e em crescimento. Tais expectativas ganharam ênfase em todas as áreas das ciências e para a sociedade, a partir do momento em que o envelhecimento populacional e as possibilidades de envelhecer bem e com saúde se tornaram uma realidade para muitos países. O envelhecimento ganhou hoje outros atributos, tais como: saudável, produtivo e ativo. Termos que, segundo Côrte (2009, p. 56), "incluem a atividade, o ócio e a questão da continuidade e da vivência no próprio ambiente social. Termos que nos permitem entender essa etapa da vida, a velhice, de uma maneira diversa e singular".

A II Assembleia Mundial das Nações Unidas sobre Envelhecimento/2002 introduziu no seu plano de ação o conceito de envelhecimento ativo, cujo termo, adotado pela OMS no final dos anos 90 , compreende o "processo de otimização das oportunidades de saúde, participação e segurança, com o objetivo de melhorar a qualidade de vida à medida que as pessoas ficam mais velhas" 6 (Opas, 2005, p. 13). Este paradigma surge como um programa de intervenção na sociedade, nos domínios sociais, econômicos, culturais, cívicos e espirituais, voltado para a melhoria da condição de vida dos idosos e para os problemas decorrentes do aumento da longevidade. Segundo Silva (2009, p. 63), "o envelhecimento ativo assenta, na sua perspectiva, sobre as provas de ação e de vitalidade que caracterizam tradicionalmente o imaginário da juventude e agora se transportam para a velhice", colocando a questão de pensarmos o envelhecimento humano ao longo da vida e a concepção de saúde como

\footnotetext{
${ }^{6}$ Para a OMS, qualidade de vida é a percepção que o indivíduo tem de sua posição na vida dentro do contexto de sua cultura e do sistema de valores de onde vive, e em relação a seus objetivos, expectativas, padrões e preocupações. É um conceito muito amplo que incorpora de uma maneira complexa a saúde física de uma pessoa, seu estado psicológico, seu nível de dependência, suas relações sociais, suas crenças e sua relação com características proeminentes no ambiente (Opas, 2005, p. 14).
} 
sinônimo de bem-estar, onde os componentes mental, social e cultural são tão importantes quanto o físico, numa atitude mais preventiva, mesmo antes do nascimento, visto que é menos dispendioso prevenir a doença do que tratá-la. Groisman ${ }^{7}$ (2002 como citado em Prado \& Sayde 2006, pp. 499-500) aponta que:

\begin{abstract}
A prevenção parece ser a saída encontrada pela gerontologia, para escapar ao binômio saúde/doença. Com o discurso da "prevenção" todos os sujeitos são passíveis de intervenção, independente do seu estado de saúde ou inserção na "normalidade". Pela urgência da prevenção não importa também quando começa a velhice, pois a prevenção deve começar muito antes dessa.
\end{abstract}

Como bem aponta o referido autor, precaver-se é assumir uma atitude mais saudável no decorrer da vida. Um indivíduo com hábitos saudáveis pode desfrutar de uma maior quantidade e melhor qualidade de vida, como também pode ser capaz de cuidar de si próprio à medida que vai envelhecendo.

A noção de envelhecimento ativo refere-se à possibilidade de envelhecer bem e com saúde; à possibilidade de uma vida longa e com experiências positivas; ao direito à proteção, segurança e cuidados adequados; à manutenção da autonomia e da independência ${ }^{8}$; à participação contínua nas questões sociais, culturais, econômicas, espirituais e civis. $O$ desafio consiste em aproveitarmos da melhor forma possível o enorme potencial que cada um conserva até o final da vida. Algumas destas abordagens são amplas e abarcam todas as faixas etárias, enquanto outras, são mais direcionadas para aqueles indivíduos que se aproximam da velhice e/ou os próprios idosos. A meta da OMS é assegurar para o maior número de pessoas a obtenção de uma melhor qualidade de vida e pelo maior tempo possível (Opas, 2005).

O conceito de envelhecimento ativo, conforme a OMS, depende também de uma variedade de outros fatores determinantes, como também da interação

\footnotetext{
7 Groisman, D. (2002) A velhice, entre o normal e o patológico. Hist Cienc Saude Manguinhos; 9 : (1) 61-78.

8 A Organização Pan-Americana de Saúde define "autonomia" como sendo a habilidade de controlar, lidar e tomar decisões pessoais sobre como se deve viver diariamente, de acordo com suas próprias regras e preferências; e "independência" entendida como a habilidade de executar funções relacionadas à vida diária, isto é, a capacidade de viver independentemente na comunidade com alguma ou nenhuma ajuda de outros (Opas, 2005, p. 14).
} 
entre eles. Estes fatores, determinantes da saúde e do bem-estar, são: determinantes transversais/cultura e gênero ${ }^{9}$; determinantes relacionados aos sistemas de saúde e serviço social ${ }^{10}$; determinantes comportamentais ${ }^{11}$; determinantes relacionados a aspectos pessoais ${ }^{12}$; determinantes relacionados ao ambiente físico ${ }^{13}$; determinantes relacionados ao ambiente social ${ }^{14} \mathrm{e}$ determinantes econômicos ${ }^{15}$. Todos estes fatores atuam no processo de envelhecimento ativo e se aplicam a todos os indivíduos, independente da idade, durante o seu curso de vida. A compreensão das evidências acerca destes fatores deve nos ajudar na idealização e elaboração de políticas e programas que obtenham êxito (Opas, 2005).

Por outro lado, a qualidade de vida do idoso não está relacionada somente à sua adaptação às novas condições de vida, mas também à maneira como as novas gerações poderão oferecer o apoio e os cuidados necessários, haja vista que o processo de envelhecimento ocorre dentro de um contexto sócio/cultural que envolve também outras pessoas, como a família, os amigos, os colegas de trabalho, os vizinhos, etc. Reposicionar o idoso neste conjunto de relações intergeracionais constitui um desafio que as sociedades devem enfrentar. Para tanto, é necessário promover políticas que viabilizem a solidariedade entre as gerações e o apoio mútuo como elemento chave do desenvolvimento, com a finalidade de incitar a harmonia social. "Esta é a razão pela qual interdependência e solidariedade entre gerações são princípios relevantes para o envelhecimento ativo" (Opas, 2005, p. 13). A solidariedade entre gerações é de fundamental importância para a construção de uma sociedade para todas as idades, principalmente no âmbito da família e da comunidade, cujos vínculos intergeracionais são valiosos na manutenção das relações e em ambos os sentidos, tendo em vista a contribuição dos idosos, tanto do ponto de vista

\footnotetext{
${ }^{9} \mathrm{~A}$ cultura, que abrange todas as pessoas e populações, modela nossa forma de envelhecer, pois influencia todos os outros fatores determinantes do envelhecimento ativo. O gênero é uma "lente" através da qual considera-se a adequação de várias opções políticas e o efeito destas sobre 0 bem-estar de homens e mulheres (Opas, 2005, p. 20).

10 Promoção da saúde e prevenção de doenças; serviços curativos; assistência a longo prazo e serviços de saúde mental (Opas, 2005).

11 Tabagismo; atividade física; alimentação saudável; saúde oral; álcool; medicamentos; latrogenia e adesão (Opas, 2005)

12 Biologia e genética; fatores psicológicos (Opas, 2005).

${ }^{13}$ Moradia segura; quedas; água limpa, ar puro e alimentos seguros (Opas, 2005).

${ }^{14}$ Apoio social; violência e maus tratos contra idoso; educação e alfabetização (Opas, 2005).

${ }^{15}$ Renda; proteção social; trabalho (Opas, 2005).
} 
financeiro como na educação e no cuidado dos netos, ou outros membros da família. Segundo o Secretário-geral das Nações Unidas, Sr. Kofl Annan: "Se criarmos redes de apoio e ambientes propícios, poderemos conseguir que a sociedade em geral se interesse por estreitar a solidariedade entre grupos de gerações e combater o abuso, a violência, a falta de respeito e a discriminação de que são vítimas os idosos" (ONU, 2003, p. 14).

\section{3- Envelhecimento bem-sucedido: predição de uma vida saudável}

Prolongar a juventude, envelhecer com qualidade de vida pessoal e social e poder desfrutar de uma velhice saudável, têm sido preocupações constantes do ser humano. Na sociedade ocidental a busca pelo significado de envelhecimento bem-sucedido deu início no final da primeira metade do século XX, em 1944, ano em que o American Social Science Research Council estabeleceu o Committee on Social Adjustment to Old Age. Além de começarem a discussão acerca da definição do conceito de envelhecimento bem-sucedido, o trabalho efetivado por este comitê resultou no desenvolvimento de instrumentos de medidas que correlacionaram o bem-estar psicológico (BEP) e o bem-estar subjetivo (BES) às estratégias de enfrentamento, autonomia e geratividade (Teixeira \& Neri, 2008).

Segundo Fonseca (2004), a subjetividade do conceito de envelhecimento bem-sucedido está relacionada à individualidade e às diferenças sócio-culturais de cada indivíduo, e apesar do seu uso generalizado na literatura gerontológica o seu conceito pode trazer alguma surpresa "dado associarmos geralmente o sucesso a representações que nada tem a ver com o que se espera habitualmente do processo de envelhecimento, o qual faz frequentemente apelo às noções de perda, declínio e aproximação da morte" (Fonseca, 2004, p. 195).

Ter um envelhecimento bem-sucedido, mediante Neri (1995), vai depender da manutenção da integridade física e mental de cada indivíduo até os últimos anos de vida, como também da capacidade de adaptação às perdas. Vai depender também das oportunidades quanto a usufruir de condições adequadas de saúde, educação, trabalho e habitação durante o seu curso de vida, além de um conjunto de outros fatores, como por exemplo: de ordem econômica (essencial à promoção da saúde e à educação); adoção de providências reais (no 
sentido de potencializar o desenvolvimento e a adaptação do indivíduo, por meio de uma educação contínua e da realização de adaptações sociais); estímulo à flexibilidade pessoal e social concernente às questões do envelhecimento. Estes fatores são essenciais à determinação da capacidade de manter papéis familiares, rede de relações informais, capacidades de autorregulação da personalidade e determinação do nível de motivação pessoal para a busca de conhecimentos e para o cultivo das relações sociais. Conforme a referida autora, todos estes fatores e determinantes são fundamentais e preditivos para um envelhecimento com qualidade, ou seja, são cruciais à determinação da saúde, da longevidade, da satisfação com a vida, do bem-estar psicológico, da saúde física, da eficácia cognitiva, da competência social, da atividade e da produtividade. Segundo C. Paúl ${ }^{16}$ (1996 como citado em Fonseca 2004, p. 200),

Quando se coloca a questão da velhice bem ou mal sucedida estamos a definir padrões de adaptação do idoso às suas atuais capacidades de funcionamento, no seu contexto de vida, implicando com isso quer critérios externos, sociais, relativos ao que se espera do idoso em cada cultura, quer critérios internos, numa perspectiva individual, o sentir e a vontade subjetiva. Estes critérios podem não coincidir e acontecer que uma pessoa seja considerada inadaptada quando se sente satisfeita, e inversamente, tornando difícil definir critérios para uma velhice bem-sucedida.

Embora existam diferentes definições operacionais ressaltando a capacidade funcional, outros indicadores também são considerados relevantes para um envelhecimento bem-sucedido, como por exemplo: a preservação de hábitos de vida saudáveis; a ausência de incapacidade; alta capacidade funcional/ independência e adaptação positiva; domínio/crescimento e participação social ativa; as condições biofísicas (como força e resistência); e estilo de vida. Teixeira e Neri (2008, p. 83) cita outros fatores tão importantes quanto estes, como o "nível educacional elevado, prática de atividade física regular, senso de auto-eficácia, participação social e ausência de doenças crônicas". Mais a mais, mediante Neri (1995), se observarmos cuidadosamente o que sucedeu com aqueles indivíduos

${ }^{16}$ Paul, C. (1996). Psicologia dos idosos. O envelhecimento em meios urbanos. Braga: Sistemas Humanos e Organizacionais. 
cujo envelhecimento apresentou características positivas e satisfatórias, poderemos estabelecer uma série de condicionantes essenciais para um envelhecimento bem-sucedido. A respeito disso Fernández Ballesteros ${ }^{17}$ (2002 como citado em Fonseca 2004, p. 199) vai fazer o seguinte comentário:

Como tudo na ciência, se trata de uma questão de probabilidade: se praticam uma gama de estilos de vida e formas de comportamento (uma dieta saudável, exercício físico e mental, atividades agradáveis, alta motivação, sentido de alta eficácia, etc.); e se, ademais, existem condições sociais favoráveis (proteção social, serviços sociais e sanitários, etc.), então, provavelmente, se envelhecerá otimamente. Mas convém ressaltar que se, apesar da prática da vida saudável, ativa e plena, a enfermidade e a dependência aparecem, em todo caso, após um determinado estilo de vida, é necessário alcançar o desenvolvimento pessoal e o bem-estar durante o máximo tempo possível, o que já constitui um objetivo em si mesmo.

No seu conjunto, todas as teorias acerca do envelhecimento bem-sucedido veem os idosos como pró-ativos, integrados socialmente, participativos em atividades socioeconômicas e culturais, com objetivos bem definidos, servindo-se de recursos úteis para a sua adaptação, para a manutenção da sua saúde física/mental e do seu bem-estar pessoal/social. Seus objetivos são direcionados para o desenvolvimento da autonomia, da auto-estima, para se atingir uma estabilidade emocional, para a vida familiar e para o cultivo das relações de amizade. Verifica-se também que as abordagens acerca do envelhecimento bemsucedido são construídas a partir de critérios como a ausência de patologias e incapacidades, adequado desempenho físico e cognitivo, manutenção do controle primário e envolvimento na vida. Ter uma velhice saudável vai depender também das escolhas que o indivíduo faz e da adoção de estratégias adequadas para lidar com as perdas e os desafios. Ou seja, não existe um caminho único de evolução para uma velhice saudável, o processo vai decorrer de forma diferenciada de pessoa para pessoa, podendo diferentes indivíduos percorrer diferentes percursos e utilizar de diferentes estratégias, o que não implica alcançar o mesmo êxito e satisfação plena com a vida (Fonseca, 2004).

17 Fernández-Ballesteros, R. (2002). Presentación. In R. Fernández-Ballesteros (dir.), Vivir con vitalidad, Vol I - Envejecer bien. Qué es y cómo lograrlo. Madrid: Ediciones Pirâmide. 
Envelhecer de forma saudável e, mais ainda, de forma consciente, implica numa reparação interior, implica em rever valores, rever projetos de vida e potencializar o futuro. Essa revisão, segundo Grunewald (2006, p. 37), "implica no investir em auto-conhecimento, exercitar desapegos, transcender, ir além de si mesmo, percebendo-se como um ser-de-relações com o mundo onde se insere, tendo a possibilidade de construir o seu novo modo de estar-no-mundo".

\section{4- Imagens, redefinições e interpretações da velhice}

O temor à velhice e a preocupação com a prolongação da vida e da juventude fez com que o homem, ao longo de toda a sua história e em todos os lugares e culturas, construísse, a partir de vários questionamentos acerca do desenvolvimento humano, uma propagação de termos e conceitos que remetem para diversas imagens, redefinições e interpretações sobre o envelhecimento e a velhice. $\mathrm{Na}$ literatura especializada encontramos várias definições conceituais sobre estes fenômenos, elaboradas numa mesma abordagem ou segundo abordagens teóricas distintas. Há casos, por exemplo, em que os termos envelhecimento e velhice são utilizados pelos mesmos autores como sinônimos ou com significados distintos, dificultando, por assim dizer, uma melhor delimitação ou definição de uma teorização mais consensual dos seus conceitos. Todavia, não podemos confundir envelhecimento com velhice: o envelhecimento é comum a todas as idades, é um fato da vida e um processo que traduz uma realidade do percurso evolutivo e natural do desenvolvimento humano, que reporta às mudanças biológicas sofridas ao longo dos anos e que envolve fatores fisiológicos, sociais, culturais e psicológicos; já a velhice (última fase do ciclo vital), será um efeito da idade na saúde e reportará aos decréscimos ou decadência das capacidades físicas e mentais, a partir da relação que se estabelece entre os diferentes aspectos biológicos, psicológicos, sociais e culturais, cujo processo de transformação do organismo implicará na diminuição progressiva da probabilidade de sobrevivência.

De acordo com Schneider e Irigaray (2008, p. 586), hoje em dia os especialistas no estudo acerca do envelhecimento e da velhice fazem referência a três grupos de pessoas mais velhas: 
Os idosos jovens, os idosos velhos e os idosos mais velhos. 0 termo idosos jovens geralmente se refere a pessoas de 65 a 74 anos, que costumam estar ativas, cheias de vida e vigorosas. Os idosos velhos, de 75 a 84 anos, e os idosos mais velhos, de 85 anos ou mais, são aqueles que têm maior tendência para a fraqueza e para a enfermidade, e podem ter dificuldade para desempenhar algumas atividades da vida diária.

Em nenhuma outra fase da vida é atribuída tantas variações e alternâncias conceituais como nessa última fase, como também a proliferação de expressões e termos utilizados para se referir à velhice, como por exemplo: pessoas de idade, terceira idade, quarta idade, melhor idade, sênior, adulto maduro, maturidade, idade maior, idade madura, idoso, velho, etc. Ainda que estas categorizações sejam bastante usuais, cada vez mais os estudos têm mostrado que o processo de envelhecimento é uma experiência heterogênea, vivida de forma individual. Conforme Neri e Freire ${ }^{18}$ (2000 como citado em Schneider \& Irigaray 2008, p. 588), o uso de tantos termos e expressões para se referir à velhice tem por objetivo "soar bem, mascarando o preconceito e negando a realidade. Se não houvesse preconceito, não seria necessário disfarçar nada por meio de palavras".

Historicamente a idade cronológica, cujo conceito é multidimensional, sempre constituiu um importante elemento de diferenciação entre os indivíduos, contudo, ela já não pode mais ser considerada como um marcador para as transformações que acompanham o processo de envelhecimento, muito menos como um fator determinante da velhice, visto que as divisões cronológicas nem sempre correspondem às etapas do processo de envelhecimento, tornando-se apenas uma forma padronizada de contagem de anos vividos. De acordo com Nogueira (2005, p. 87), "com base na idade, categorizam-se as pessoas e é possível encaixá-las em uma determinada etapa do ciclo vital que se define com base em expectativas de características biológicas, psicológicas e sociais".

A idade e o processo de envelhecimento possuem outras dimensões e significados que excedem as dimensões da idade cronológica, como exemplo podemos citar as condições físicas, funcionais, mentais e de saúde, o que equivale afirmar que podemos perceber diferentes idades biológicas, sociais e psicológicas em sujeitos com a mesma idade cronológica. As idades biológicas,

${ }^{18}$ Neri, A. L., \& Freire, S. A. (Orgs.). (2000). E por falar em boa velhice. Campinas: Papirus. 
sociais e psicológicas, segundo Schneider e Irigaray (2008, p.592), "são relevantes e importantes para a compreensão do processo de envelhecimento, mas não para a sua determinação, pois a velhice é apenas uma fase da vida, como todas as outras, e não existem marcadores do seu começo e do seu fim". A idade biológica é geralmente definida pelas alterações corpóreas e mentais que sobrevêm no decorrer de toda a existência humana, já a idade social, esta é definida pela aquisição de hábitos e status social, determinando papéis sociais ou expectativas relacionadas aos indivíduos de uma mesma idade, grupo social e cultura. Conforme os referidos autores, "um indivíduo pode ser mais velho ou mais jovem dependendo de como ele se comporta dentro de uma classificação esperada para sua idade em uma sociedade ou cultura particular" (Schneider \& Irigaray, 2008, p. 590). Este comportamento envolve características como hábitos, linguagem, tipos de vestimenta, posição de liderança, etc. Quanto à idade psicológica, esta é definida como sendo um conjunto de "habilidades adaptativas dos indivíduos para se adequarem às exigências do meio" (Schneider \& Irigaray, 2008, p. 591), cujas características (atenção, aprendizagem, memória, orientação, concentração, inteligência, controle emocional), em maior ou menor grau, irão discernir os adultos "jovens psicologicamente" dos "velhos psicologicamente".

Em parte, a caracterização do indivíduo como velho é dada quando ele começa a ter lapsos de memória, dificuldade de aprendizado e falhas de atenção, orientação e concentração, comparativamente com suas capacidades cognitivas anteriores. Sabe-se que mesmo durante o processo de envelhecimento normal, algumas capacidades cognitivas como a rapidez de aprendizagem e a memória diminuem naturalmente com a idade. No entanto, estas perdas podem ser compensadas por ganhos em sabedoria, conhecimento e experiência. (Schneider \& Irigaray, 2008, p. 591)

O significado de velhice, segundo Resende e Neri (2009, p. 769), geralmente é construído "a partir da percepção pessoal, por intermédio dos valores e experiências, crenças e atitudes que cada um internaliza e também a partir da história interacional do indivíduo com eventos contextuais de natureza reforçadora, avaliativa e diretiva". Mais do que um conceito genético-biológico, a velhice é uma construção social que irá adquirir significados diferentes 
relacionados ao gênero, à história pessoal e ao contexto histórico-cultural de cada indivíduo. Deste modo, a velhice deixa de ser interpretada apenas como uma fase voltada para os decréscimos biológicos, passando a ter diferentes construções, de acordo com as perspectivas dos papéis sociais das pessoas, com as relações de poder e de gênero e com os conflitos que fazem parte da vida, podendo encaminhar situações de readaptação, criação de valores e/ou exclusão. Já as representações sociais construídas sobre a velhice, e que tradicionalmente a associam à reforma (tema que será abordado numa próxima etapa), estas irão variar de acordo com o contexto histórico, econômico, político, geográfico e cultural de cada indivíduo, que relacionados, são fundamentais na categorização de um indivíduo como sendo velho ou não.

\section{5- Idadismo: a construção de uma imagem positiva como aspecto vital}

Ainda que nas últimas décadas se tenha realizado um significativo investimento científico neste domínio, o ato de envelhecer ainda adquire uma conotação negativa, ou seja, no contexto atual a sociedade ainda apresenta dificuldades em lidar com o envelhecimento dos seus cidadãos. Embora alguns estudos apontem uma visão mais otimista em relação à velhice, ainda é perceptível a discriminação e o preconceito etário ou idadismo, que relacionado a alguns estigmas podem reforçar sentimentos de inadequação e baixa-estima no idoso, condicionando-o a situações de isolamento e exclusão, levando-o a não viver a sua velhice de forma plena, expressiva e prazerosa. Como bem aponta Guimarães ${ }^{19}$ (1997 como citado em Minayo \& Coimbra Junior 2002, p. 16), "nos dicionários emocionais da população, velhice é sinônimo de decadência, de decrepitude e de perda de dignidade". O notável é que as sociedades que mais exclusivamente têm destacado a possibilidade de um envelhecimento positivo e com sucesso são as mesmas onde se encontra, ainda, bastante arraigada, uma visão estereotipada da pessoa idosa, configurada no idadismo (discriminação por idade) e na "tendência generalizada para considerar os velhos como um grupo social homogêneo, redutível à sua idade cronológica, cuja representação é por

${ }^{19}$ Guimarães, R. M. (1997). Ciência, tempo e vida. Arquivos de Geriatria e Gerontologia, 1 (1):7-9. 
sua vez claramente negativa" (Fonseca, 2004, p. 196). Segundo Ricardo Moragas (2004), como todo "ismo" (por exemplo, racismo), o idadismo implica numa exclusão do outro, que muitas vezes começa em casa, entre os membros da família, na forma como se dá o tratamento aos mais velhos, principalmente por parte dos mais jovens. Segundo Ferreira (2015, p. 29),

O conceito de idadismo, com origem na psicologia americana dos anos 70, refere-se a atitudes e comportamentos discriminatórios com base na idade. As manifestações de caráter idadista podem ser direcionadas a diferentes grupos etários, mas são as pessoas mais velhas que são mais frequentemente alvo de atitudes e comportamentos negativos. A experiência de discriminação aumenta à medida que a idade vai avançando.

O preconceito etário institui a primeira etapa da discriminação por idade, e muitas vezes têm início a partir da idade convencional para a reforma, ou seja, a partir dos 65 anos. Atingida esta idade o indivíduo passa a ser avaliado como menos produtivo, menos seguro, menos estável, incapaz, inadequado, conservador, mais propenso a acidentes e portador de dificuldades e limitações. Muitos trabalhadores de mais idade, segundo Neri (1995), são descartados do mercado de trabalho por se tornarem, segundo alguns, arcaicos em relação aos avanços e às mudanças tecnológicas, educacionais e econômicas, com a justificativa de que já não são capazes de enfrentar os desafios exigidos. Alda Britto da Motta aponta que é como se os indivíduos "estivessem numa dimensão não produtiva e terminal da natureza - resíduos da natureza, objetos de necessário descarte. Não se reproduzem mais, não produzem trabalho e bens materiais (ou não se permite que produzam, segundo os cânones do capitalismo) (Minayo \& Coimbra Junior, 2002, p. 38)". Conforme os referidos autores (2002, p. 16), "a visão depreciativa dos mais velhos tem sido, através dos tempos modernos, alimentada profundamente pela ideologia 'produtivista' que sustentou a sociedade capitalista industrial". No contexto atual a categoria dominante para classificar os idosos é referenciá-los à ausência do trabalho e colocá-los no lugar de "não produtivos". Se o indivíduo não pode mais produzir como supostamente deveria, pouco serve para a sua comunidade, menos ainda para o país. Nos seus 
estudos, Vicente Faleiros (2009, p. 64) comenta que "na gerontologia o envelhecimento e a velhice não se resumem a um estereótipo e nem podem ser reduzidos a um estigma, mesmo num contexto construído socialmente para o lugar do improdutivo".

Por outro lado, estamos inseridos numa sociedade onde os ícones de referência se identificam com a juventude, onde os diversos meios de comunicação supervalorizam e associam a imagem do jovem à saúde, à força, à habilidade de ser produtivo ou reprodutivo, como também à beleza, ao poder econômico, ao status e a tantos outros "valores controversos" que no decorrer da vida vão desaparecendo. Já a velhice, esta é evidenciada pela sociedade de forma contrária aos padrões estéticos reforçados pelos meios de comunicação. De acordo com Nogueira (2005), a velhice é muitas vezes vista como um defeito que precisa ser reparado ou disfarçado pelas diversas técnicas que asseguram o rejuvenescimento ${ }^{20}$. A juventude, como tudo indica, transforma-se em um ideal desejável, onde a aparência de um corpo jovem, belo, perfeito, saudável e resistente ao envelhecimento passa a assumir um papel importante na construção da identidade, além de uma condição fundamental para que o indivíduo se sinta inserido e valorizado socialmente.

São corpos construídos diante das inúmeras possibilidades de transformação estéticas permitidas pela ciência, tecnologia e arte, modificados na sua aparência na busca de um lugar social ou de uma inserção cultural. Parece não haver limites para a intervenção tecnológica no nível corporal, e a concepção de corpo natural dá lugar a uma concepção de corpo como projeto. Um corpo dotado de plasticidade, modelado e transformado e que pode ser compreendido não só como um ideal a ser perseguido, mas como um bem a ser adquirido e conquistado pelas pessoas. (Nogueira, 2005, p. 94)

Para além dos padrões estéticos, outra ideia bastante generalizada é a de que a velhice, mediante Fonseca (2004, p. 106), "corresponderia a uma espécie

20 É comum a recorrência generalizada de mecanismos de combate e resistência ao envelhecimento e de mecanismos que visam desnaturalizar o processo de envelhecimento, apoiados pela intensa oferta de recursos e práticas que adiam ou negam os efeitos do envelhecimento. A experiência de envelhecimento tende a ser vista como uma opção individual, um estilo de vida, frente a um leque variado de produtos e serviços, e não mais como uma vivência inevitável do passar dos anos (Nogueira, 2005, p. 94). 
de 'segunda infância', com tudo o que isso traduz em termos de infantilização, dependência e diminuição da responsabilidade individual dos idosos, conduzindo a uma inevitável redução do seu estatuto social".

Todo esse panorama negativo faz com que a vivência do processo de envelhecimento, que deveria ser natural, aconteça de maneira estigmatizada, se tornando uma ameaça para a autoestima e o bem-estar do idoso, fazendo com que ele se sinta fraco, sem perspectivas, sem poder, sem vontade ou entusiasmo para seguir com a vida, levando-o a desistir dos seus objetivos e a recolher-se no passado, e a não encontrar, a partir daí, significado ou sentido para a sua existência. Dominados por conceitos negativos os idosos se veem rodeados por um ambiente hostil e ameaçador, desconfiam de tudo, se acham incapazes e incompetentes, perdem o seu sentido de utilidade, o seu espaço, o seu prestígio, se sentem escravos da vontade dos outros, sentem que qualquer esforço é inútil e que nada vale apena, além de demonstrarem comportamentos de frustração, resentimento e desamparo (Paz, 2011). Estas são as razões que levam muitos idosos a se isolar, a levar uma vida anti-social e a elaborar uma personalidade solitária, afastada da realidade. Todavia, o idoso, como qualquer outra pessoa, é sociável por natureza, e o seu isolamento pode originar deficiências na sua qualidade de vida, como por exemplo, deficiências na alimentação, nos hábitos higiênicos e na personalidade psicossocial.

De acordo com a OMS (ONU, 2003), é de responsabilidade nossa, dos governos e de outros agentes importantes, em particular das organizações nãogovernamentais e famílias ${ }^{21}$, por intermédio de reflexões, opiniões e pesquisas, contribuirmos para o fim do idadismo e para a superação dos preconceitos erigidos acerca da velhice, que podem desenvolver-se em ritmos, épocas e direções distintas. É de responsabilidade nossa oferecermos o apoio necessário à saúde e à promoção do bem-estar dos idosos, como também propiciarmos a eles ambientes favoráveis e permitirmos que eles exerçam 0 seu direito de participação plena numa vida social, cultural, política e econômica. É necessário a construção de uma nova consciência, "que busque quebrar mitos e tabus, destruir

${ }^{21}$ A cooperação na família constitui o tipo mais importante de cooperação social, seja na família de origem, de destino ou em ambas. A cooperação familiar se manifesta numa diversidade de funções: Atendimento das necessidades primárias, como alimentação, vestuário, moradia; educação social e transmissão dos valores familiares e culturais do grupo; ajuda econômica a qualquer momento, segundo a necessidade do sujeito; apoio emocional do nascimento até a morte (Moragas, 2004, pp. 12-13). 
estereótipos, e que crie novas formas de viver, redefinindo modelos econômicos, atacando pré-conceitos, mostrando que o Ser que amadurece pode ser tão transformador e criativo quanto qualquer outro" (Grunewald, 2006, p. 37). Como bem aponta Fonseca (2004, p. 109), cabe a nós olharmos para um idoso exatamente como pessoa, "com direitos e obrigações, com alegrias e angústias, com desejos e frustrações, enfim, exatamente como uma criança, um jovem ou um adulto, ou seja, como uma pessoa que vive a sua condição de vida à semelhança de qualquer outra".

Cada vez mais as pessoas se recusam a admitir que irão envelhecer um dia, evitando, o mais possível, confrontar-se com a ideia do envelhecimento, cultivando sentimentos de "gerontofobia". De acordo com Viktor Frankl22 (2002 como citado em Gomes et al. 2006, p. 10), ao invés de demonstrarem atitudes de discriminação e preconceito em relação aos idosos, os mais jovens deveriam invejá-los, pois eles têm muito mais do que oportunidades e possibilidades futuras, "eles têm realidades no passado - as potencialidades que efetivaram, os sentidos que realizaram, os valores que viveram - e nada nem ninguém pode remover jamais seu patrimônio do passado".

\section{6- Velhice: uma representação social associada à reforma}

Nas sociedades ocidentais as fases da vida têm sido cada vez mais padronizadas e institucionalizadas pelo Estado. De acordo com Grunewald (2006, p. 36), do ponto de vista sociológico os indivíduos transitam em três tempos distintos: o primeiro tempo seria o da infância, adolescência e juventude, voltado para a formação, que é quando "o indivíduo adquire habilidades para produzir na sociedade, expande seus espaços, aprende a tornar-se independente"; o segundo tempo, a idade adulta, que está associada à procriação, à inserção no mercado de trabalho e à produção, momento em que o indivíduo "está no auge de suas habilidades, vivendo em sua sociedade o momento mais reforçador; ele solidifica espaços disponíveis, conquista outros e chega ao máximo de seu potencial"; já o terceiro tempo, o da velhice, é o tempo de não produção, "onde ocorre o

22 Frankl, V. E. (2002). Em Busca de Sentido. Petrópolis, RJ: Editora Vozes. 
decréscimo do seu vigor físico e das atividades que são decorrentes deste vigor", é o momento da reforma, quando seu espaço profissional se extingue e sua morte social é decretada ${ }^{23}$, o que não é verdade.

No que concerne à reforma, é algo que vai surgir associada à idade e que compõe hoje um aspecto estrutural do curso da vida humana nas sociedades industrializadas, constituindo-se num acontecimento que se traduz pelo afastamento da atividade profissional que vinha sendo executada regularmente durante anos e pelo direito a um rendimento econômico proveniente do sistema de pensões. Conforme Fonseca (2004, p. 360), o afastamento profissional pode ser pensado como "um acontecimento de vida que origina um processo de 'transição-adaptação' no âmbito do qual se forja um resultado adaptativo mais ou menos satisfatório" e que vai envolver mudanças em variados aspectos da vida, além de instituir períodos particularmente sensíveis ao surgimento de alterações no funcionamento psicológico dos indivíduos, com inevitáveis implicações ao nível do respectivo bem-estar psicológico e social. Silva $(2009$, p. 67) reforça que a reforma é um momento de "ruptura nas trajetórias dos sujeitos que, para permanecerem em atividade, precisam reinventar interesses e novas formas de ocupação".

Muitos indivíduos desejam se ver livres da obrigação de trabalhar para usufruírem do seu tempo de reforma, como também aspiram por um tempo de vida prolongado, totalmente livre e em boas condições de saúde, que lhe permita desfrutá-la como um tempo produtivo e satisfatório, como possibilidade de um tempo voltado para a realização pessoal e execução de projetos do seu interesse, como também para o lazer e o acúmulo de outras fontes de rendimento, através do prolongamento da vida ativa e do exercício de outras funções. Todavia, estas possibilidades vão depender do estatuto sócio/econômico/cultural de cada indivíduo, como também da idade a que reformou. Por outro lado, enquanto uma

\footnotetext{
${ }^{23}$ Conforme Grunewald (2006, p. 36), nesta última fase da vida os papéis sócio-familiares também vão desaparecendo à medida que os filhos crescem e vão embora de casa; seu papel de pai (ou mãe) vai deixando de existir, culminando com a 'Síndrome do Ninho Vazio'. Seu papel de trabalhador, isto no contexto sócio-econômico-cultural, se foi com a aposentadoria. Seu papel de filho deixa de existir quando seus pais falecem. Psicologicamente, ocorre uma "diminuição do eu", necessitando a reformulação de valores para reestruturar sua auto-imagem, auto-estima, seu reconhecimento enquanto Ser, pois, o desaparecimento dos meios com os quais estava acostumado a contar, somado ao surgimento de barreiras que ele percebe como insuperáveis e a mudança das expectativas pessoais e sociais, gera sentimento de confusão existencial que acaba por criar o ciclo vicioso solidão/angústia que finaliza em isolamento, trazendo consigo desajustes.
} 
maioria dos trabalhadores aguardam anciosos pelo momento da reforma, uma outra parte, ao contrário, a recusa, preferindo trabalhar até o limite das suas forças. Mas o que motivaria um indivíduo a não optar pela reforma e sim pelo trabalho? Acerca desta questão Fonseca (2004, p. 363) faz o seguinte comentário:

\begin{abstract}
Antes de mais, a vida profissional proporciona aos indivíduos (para além dos rendimentos econômicos que dela retiram) uma oportunidade para a ocupação do dia-a-dia, bem como para a atribuição de um sentido social à existência, relacionado com a ocupação que desempenham. Tal como na vida familiar, a vida profissional pode incorporar múltiplos tipos e variedades (manual versus intelectual, de natureza pública versus privada, etc.), devendo a relação das pessoas com a profissão ser vista como uma relação complexa, que gira principalmente em torno do significado que o trabalho adquire para cada indivíduo (forma de ganhar a vida, forma de ser útil à sociedade, meio de promoção social, etc.). Para além disso, trabalhar não é apenas uma questão de realização de tarefas, implica também oportunidades de relacionamento social e de preservação de uma imagem pessoal de competência, não podendo a compreensão dos mecanismos psicológicos implicados na "passagem à reforma" desligar-se destas realidades.
\end{abstract}

Conforme Aquino e Martins (2007, p. 480), nas sociedades pós-revolução industrial o trabalho "ocupou o lugar de atividade central na inserção social e constitui fator fundamental da produção subjetiva ao longo da sociedade moderna". O trabalho, além de integrar o indivíduo nas redes sociais e contribuir para o sentido de pertença, de autonomia e de participação na vida econômica e social, contribui para a construção de uma consciência de cidadania e para a definição de uma identidade pessoal. Segundo Fonseca (2004), o trabalho é uma atividade que representa mais que uma solução para os problemas econômicos, ou algo que nos ajuda a organizar a vida e a estabelecer relações. O estatuto profissional também nos ajuda a ter um conceito de nós próprios, além de ser um grande indicativo do nosso valor, constituindo uma identidade, e que será perdida a partir da reforma. Nesta perspectiva, a reforma pode ser percebida como a renúncia de um papel determinante, e que pode afetar, de forma negativa, no desempenho de outros papéis no decorrer da vida. É como se o indivíduo não 
tivesse mais o seu lugar de pertença, nem colegas e amigos, o que termina por provocar um sério abalo na sua auto-estima, além da sensação de desconsolo, dado à interrupção daquilo que ele considerava ser o grande objetivo da sua vida. Para uma maioria dos trabalhadores a reforma não assinala apenas 0 encerramento de uma atividade profissional, mas o fim de uma trajetória que deixou marcas na vida. Nesta perspectiva, a reforma pode ser percebida como a renúncia de um papel determinante, que irá afetar, de forma negativa, no desempenho de outros papéis no decorrer da vida.

[Todavia], a maior representatividade da população mais velha, e o seu consequente peso social e político na sociedade, a longevidade da reforma e a melhoria das condições de saúde, a par das novas ofertas segmentadas de mercado (na prestação de serviços, lazer, turismo e apoio geriátrico) parecem abrir novas possibilidades de identidade na velhice. (Silva, 2009, p. 28)

Segundo a mesma autora, esta "reinvenção identitária" implica um ato de superação das imagens negativas, discriminatórias e preconceituosas, construídas socialmente acerca do idoso. Minayo e Coimbra Junior (2002, p. 23) comentam que "os tempos atuais permitem aos idosos, como nunca antes, construírem sua nova identidade sob uma ótica de trabalho não obrigatório, mas de utilidade e de sentido", o que possibilita a criação e o desfrute de novos espaços de expressão, menos discriminatórios para os desejos e possibilidades de realização dos idosos, focados noutras formas de estar no mundo e na sociedade. Mesmo assim, para uma maioria, permanecer no trabalho pode ser bem mais vantajoso, principalmente para aqueles indivíduos que exercem cargos de prestígio e que têm as suas competências reconhecidas. Para estes indivíduos, cuja vida profissional desempenhada lhes permitiu desenvolver um "plano de carreira bem-sucedido" ou uma "vida profissional de sucesso", é mais possível que o processo da reforma originasse sentimentos ambivalentes ou mesmo de frustração.

Contudo, apesar de alguns trabalhadores não interpretarem a reforma como algo benéfico, "a tendência recente tem sido no sentido desta se generalizar e ocorrer cada vez mais cedo no ciclo de vida dos indivíduos" (Fonseca, 2004, p. 
364). Na maioria dos casos, contrariando as capacidades físicas e mentais para o exercício de uma função, a introdução do processo da reforma, do esquema de pensões e o afastamento do trabalho, são determinados pela idade cronológica. Todavia, a idade já não pode ser vista de forma estática, dado ao fato de os indivíduos atingirem a reforma cada vez mais cedo, passando prematuramente à reforma antecipada, numa fase ainda intensa de investimento na vida profissional.

Isto significa que a reforma passa a acontecer, genericamente, em plena meia-idade (porque surge cada vez mais cedo na vida dos indivíduos) e, mesmo que suceda aos 65-70 anos, no que habitualmente se designa já por velhice, não deve ser vista como o princípio de algo que se reveste uma conotação negativa (porque a maior longevidade está hoje em dia associada a noções como atividade e vitalidade). (Fonseca, 2004, p. 110)

A passagem para a reforma por volta dos 50 anos vem se tornando um acontecimento bastante decorrente, seja por vontade própria ou devido a circunstâncias diversas, ao lado das reformas tradicionais (65-70 anos), das reformas por incapacidade física e de ocorrências menos frequentes, como por exemplo, indivíduos que se recusam a abandonar a atividade profissional que desempenha e que, consequentemente, não aceitam reformar-se, tornando assim, muitíssimo variável o modo como se pode dar o afastamento da vida profissional e a entrada na reforma. Outros dois fatores que contribuem para essa variação são as alterações do ponto de vista demográfico e do nível da dinâmica de funcionamento do mercado profissional.

De acordo com Fonseca (2004), para muitos trabalhadores a reforma ainda constitui um marco, que tradicionalmente é conotado como sendo o ritual de passagem para a entrada na velhice, porém, as ocorrências indicam que já não é possível pensarmos o processo da reforma simplesmente como prenúncio para a entrada na velhice ou como uma linha de demarcação entre a meia-idade e a velhice, "quer porque o abandono da vida profissional pode dar-se em idades e segundo modalidades muito diversificadas de pessoa para pessoa, quer porque a própria transição do 'trabalho' para a 'reforma' é hoje muito mais fluída que dantes" (Fonseca, 2004, p. 111). Mediante Silva (2009, p. 64), este novo 
paradigma "parece querer dissociar o tempo de reforma da velha imagem de declínio e de dependência e fundar-se na ideia de uma reforma em bom estado de saúde e de usufruto dos tempos de lazer", voltada para a realização de projetos pessoais e de atividades verdadeiramente satisfatórias.

Fonseca (2004, p. 371) aponta ainda que "o abandono do mundo do trabalho deveria levar o indivíduo, em princípio, a experimentar um ânimo mais elevado do que no decorrer dos anos de vida profissional, onde as causas para a ocorrência de estados de tipo depressivo seriam mais evidentes". Porém, o que se percebe, é que se para alguns a reforma representa um momento de libertação e renovação, no sentido de se estabelecer novas metas, de fugir da rotina casa/trabalho/casa, de investir na formação e no lazer, além de constituir um tempo precioso e recompensador do qual podem gozar os frutos de toda uma vida dedicada ao trabalho e apreciar novas atividades e práticas, para outros, ao contrário, a passagem para a reforma nem sempre é encarada com positividade, mas sim como "um momento de sofrimento e perda (de objetivos, de prestígio, de amigos, de capacidade financeira)" (Fonseca, 2004, p. 366), marcada pela ausência de sentido, pela doença, pelo sentimento de vazio e incompletude. $O$ impacto pode ser maior ainda quando a reforma surge subitamente, colocando 0 indivíduo frente a uma situação de todo imprevista, mais ainda se ela ocasionar prejuízos acerca do seu bem-estar material, já que pode trazer consigo uma mudança do estatuto financeiro.

É lamentável o fato de os indivíduos, com o advento da reforma, terem a sua renda e o seu padrão de vida reduzidos. A privação mais grave ocorre com aqueles que vivem sozinhos e dependentes de um mísero benefício, cujos valores não são suficientes para a manutenção da sua integridade, afetando, de forma significativa, na sua saúde, no seu bem-estar e no seu estilo de vida. Conforme Squire (2005, p. 14), "o dinheiro tem uma importância vital num envelhecimento bem-sucedido, uma vez que mantém a independência e a autonomia, permitindo às pessoas idosas o acesso a um padrão de vida aceitável". 


\title{
1.7- O tempo da reforma: um tempo para se viver o ócio
}

A reforma antecipada, como vimos, é um fato cada vez mais ocorrente na atualidade, e que vem proporcionando aos indivíduos o confronto com uma nova distribuição do tempo. Afinal, como melhor ocupar o tempo da reforma a fim de torná-lo mais satisfatório? Para muitos indivíduos o tempo da reforma pode significar um problema, principalmente para os homens, que terminam por considerar o trabalho bem mais gratificante do que a perspectiva de acordarem pela manhã e não saberem exatamente o que fazer. Para estes indivíduos, o afastamento do mundo laboral certamente será interpretado como um mal, em muitos casos, difícil de superar.

\begin{abstract}
A opção de voltar a trabalhar após a reforma, parcialmente ou a tempo inteiro, encontra na sua origem uma variedade de razões, que incluem necessidades reais de ordem financeira, o interesse em ver aumentado o rendimento disponível para com isso satisfazer desejos de várias ordens "apenas por uma questão de gosto ou de prazer" (viagens, hobbies, colecionismo, arte, etc.), a vontade de continuar a atividade profissional "sem a qual não se consegue viver", a concretização de sonhos sistematicamente adiados e que muitas vezes corresponderiam até à "verdadeira vocação" do indivíduo (abrir uma livraria, montar um negócio, dedicar-se ao turismo, tornar-se consultor, fazer bolos, etc.), ou, simplesmente, pelo fato de alguns meses de "reformado" terem sido suficientes para se concluir que não se é capaz de ocupar o tempo de outra forma que não seja a trabalhar. (Fonseca, 2004, p. 380)
\end{abstract}

Não encontrar alternativas, senão 0 trabalho, para preencher o tempo acontece, segundo Fonseca (2004), principalmente com aqueles indivíduos que não conseguem desenvolver um padrão de vida alternativo ou entre aqueles que vivem em lugares mais despojados de oportunidades. Para estes indivíduos, o excesso de tempo representará um aborrecimento, dado ao fato de não saberem exatamente como preenche-lo, buscando fazer "qualquer coisa" simplesmente para "matar o tempo". E "viver o tempo" ao invés de "matá-lo", conforme Cuenca (2009), é buscar fazer algo que se gosta, que faça sentido, que proporcione realização e bem-estar pessoal. 
Fonseca (2004) comenta que no período da reforma as novas ocupações deverão ganhar um papel de relevo no cotidiano do indivíduo, visto que permanecer ativo e participativo são condições necessárias para se viver bem e com sucesso a velhice. Se o trabalho, enquanto atividade central até então, foi primordial ao longo da vida, a partir da reforma outras atividades deverão assumir o meio e o fim central para continuar a manter o indivíduo ativo, vivo, independente, autônomo e socialmente integrado, preenchendo de forma satisfatória o seu tempo. No período da reforma as novas possibilidades de comunicação, de ampliação cultural e de participação grupal, entre outras atividades voltadas para a manutenção do lazer e o exercício do ócio, como também o trabalho voluntariado ${ }^{24}$, deverão ser colocadas em primeiro plano.

De acordo com Cuenca (2009, p. 253), "o desfrute da reforma e da velhice está relacionado com a forma de ser e com escolhas específicas, que determinam uma maneira de ver a vida e as relações com os demais". A decisão de como melhor ocupar o tempo e torná-lo mais satisfatório, a partir da realização de atividades que realmente confiram sentido, é de extrema importância para a manutenção do bem-estar psicofísico e da subjetividade, levando em conta que, vivenciar experiências verdadeiramente satisfatórias e em maior profundidade pode ajudar os indivíduos a afrontar as repressões provocadas pela necessidade do trabalho. Esse tempo só ganhará significado e importância a partir do momento em que os indivíduos tomarem os devidos cuidados na escolha das atividades que pretendam realizar. Mediante Fonseca (2004, p. 397), "a seleção de atividades a desenvolver (sejam elas simples ou complexas) é, pois, uma das decisões a tomar na sequência da 'passagem à reforma', acabando por condicionar o ritmo cotidiano de vida na medida em que esta passa a girar, em larga medida, em torno dos tempos livres". É importante que o indivíduo busque

\footnotetext{
${ }^{24}$ No que concerne ao trabalho voluntariado, por exemplo, Tomás (2001 como citado em Ferreira 2006, p. 33), sublinha que esta atividade ajuda o indivíduo a preencher o vazio pessoal/social promovido pela reforma. "Os indivíduos que se dedicam ao voluntariado atribuem um significado positivo à sua ocupação do tempo, não desvalorizam o que fazem, têm atitudes e discursos mais positivos relativamente à atividade. Sentem-se "ativos" até ao ponto de referirem-se a esta atividade como "trabalho" porque verdadeiramente ocupa uma grande parte do seu tempo, se o assumiram como profissão eleita, vocacional". As associações que possibilitam o trabalho voluntariado na maioria das vezes vêm em resposta aos múltiplos problemas sociais, propiciando uma abertura e espaço para que os indivíduos, inclusive reformados, possam desenvolver ou se integrar em atividades solidárias e prazerosas que, tanto do ponto de vista pessoal como social, enquanto retorno, gratificam aqueles que as realizam.
} 
acertar nas escolhas que faz, a fim de substituir aquelas atividades que eram significativas, exercidas no decorrer da sua vida ou do seu papel de trabalhador, por atividades igualmente satisfatórias, já que estas serão determinantes para se garantir a satisfação com a vida, o otimismo e o entusiasmo nos anos futuros.

Conforme o referido autor, muitas das escolhas que os indivíduos fazem refletem experiências incorporadas do passado profissional ou de hábitos anteriores, adquiridos e desenvolvidos ao longo da vida, como também as esperanças para o futuro. A exemplo disto ele aponta que "uma pessoa com predisposição prévia para a 'aventura' tenderá a acentuar as atividades relacionadas com esse padrão, ao passo que uma pessoa de estilo sedentário mais facilmente irá encarar a reforma como um tempo de descanso" (Fonseca, 2004, p. 398). Muitos indivíduos também associam a sua idade a determinadas atividades (geralmente mais passivas que ativas). Esta associação muitas vezes termina por afetar na tomada de decisões, levando-os a não desempenhar certas atividades porque, segundo eles, "não são apropriadas para velhos", o que nem sempre é verdade.

De acordo com Cuenca (2009), pensar o tempo da reforma como um tempo que pode ser bem aproveitado, vivido com total liberdade e de maneira bem criativa, é percebê-lo como um tempo de desfrute, voltado para a reposição física e mental; é refletir sobre as possibilidades de um envelhecimento dotado de sentido; é buscar atribuir novos significados à vida; é reconhecer uma via de encontro consigo mesmo; é resgatar valores essenciais; é desenvolver outras formas de agir e perceber sobre essa nova realidade. Aquino e Martins (2007, p. 498) consideram que nos tempos livres "o sujeito experimenta a sensação de vivenciá-lo sem nenhum tipo de pressão ou compromisso com produtividade. É um tempo de compromisso consigo mesmo, pleno de autocondicionamento". 


\section{CAPÍTULO II}

\section{O ÓCIO COMO CONSTITUINTE DA VIDA}

\subsection{Incorporando valores: o ócio para além do senso comum}

O termo ócio, do latim otium, é uma derivação da palavra grega skholé, cujo vocábulo deu origem à palavra schola (escola). De acordo com Manuel Cuenca (2009), ambos os termos, no seu sentido mais nobre, podem ser entendidos como ocupação desejada, suave e prazerosa, voltada para o exercício da contemplação intelectual da beleza, da verdade e do bem. Conforme o referido autor, ócio, enquanto fruto das horas vagas, do descanso e da tranquilidade, representa uma condição da existência humana e diz respeito às atividades próprias dos cidadãos livres e às ações não utilitaristas, que tem como propósito capital alcançar o fim supremo do ser humano: a felicidade ${ }^{25}$.

Ao longo dos séculos, paulatinamente, foram talhadas concepções diversas sobre o entendimento de ócio, gerando inúmeras contradições acerca do seu real significado, do seu sentido e dos seus valores. A sociedade moderna e industrial, por exemplo, em prejuízo ao ócio contemplativo grego, deu a ele um caráter institucional e, desde então, o seu entendimento vem sendo vinculado à noção de tempo livre, percebido como um tempo de folga ou férias, voltado para o descanso laboral, para o divertimento e para a manutenção do lazer ${ }^{26}$, porém, sem uma significação ou um sentido especial em si. Como o ócio abriga a ideia de descanso, passou a ser confundido também com "ociosidade", que no seu sentido corrente resguarda valores negativos, como desocupação, descompromisso, falta do que fazer e improdutividade, dado ao fato de não produzir "bens de mercado". Valores estes, que foram incutidos ao longo da história da industrialização, que teve como principal interesse as conquistas econômicas, a produtividade e o lucro. Desde então, contrário ao que outrora

\footnotetext{
${ }^{25}$ Segundo Cuenca (2009), o filósofo grego Aristóteles já definia o ócio como sendo o "princípio de todas as coisas".

${ }^{26}$ O tempo livre, a partir do seu viés industrial, dá passo também ao surgimento da compreensão do lazer, que passa a ser concebido como uma atividade que tem sua base ancorada na existência de um tempo livre, fomentado e reconhecido legalmente, e que poderia ser exercido autonomamente pelos trabalhadores, tendo por base sua condição socioeconômica e seus valores sociais (Aquino \& Martins, 2007, p. 491).
} 
representava um valor nobre de vida educativa, contemplativa e um ideal de sabedoria, o ócio passou a adquirir outras conotações, e cada vez mais depreciativas, sendo associado também à ideia de preguiça, vadiagem, libertinagem e desordem, além de ter sido apregoado pela influência religiosa puritana como sendo o "pai de todos os vícios". Assim, enquanto o ócio é percebido como o "lugar de toda sorte de liberdade marginal", o trabalho, ao contrário, é interpretado como "uma grande virtude". Mediante Martins (2014, p. 109),

Como o ócio abriga a ideia de repouso, parada desejada, momento para deixar vagar os pensamentos, foi fácil confundi-lo com ociosidade nas sociedades que atribuíram ao trabalho um caráter divino - ou, de maneira mais espiritual, uma forma de adorar Deus. Esta compreensão do ócio como atividade nociva é totalmente oposta ao que se propaga sobre o ócio enquanto contemplação (nas culturas helênicas, principalmente), além de estar impregnada da mentalidade puritana, na qual o ócio carregou por muito tempo o título de "pai de todos os vícios".

Já na contemporaneidade, a sociedade tecnológica e do consumo, apoiada nos excessos, nos instintos e no prazer, de uma forma diferenciada, fez do ócio um mecanismo gerador de ideias consumistas, associando-o a valores hedonistas, como a busca excessiva pela felicidade enquanto propósito mais significante da vida, conferindo ao verbo "comprar" o significado de autorrealização, satisfação e bem-estar pessoal, a partir da oferta de "produtos de lazer", que tem como meta suprir os "sonhos de consumo". Consumir, então, tornou-se uma fonte de satisfação, um subterfúgio que se identifica com o egoísmo, onde o "ter" é supervalorizado em relação ao "ser".

Com um nível de consciência mais superficial, o homem percebe menos e tende a não valorizar aspectos abstratos e subjetivos da realidade, ficando assim esquecidos ou deixados em segundo plano alguns valores como a serenidade, a sensibilidade, a contemplação, etc. (Rhoden, 2014, p. 5) 
Nos dias atuais a ideia de ócio tem sido associada ao cumprimento de certas atividades, tais como: dançar, cantar, viajar, ler, desenhar, praticar esporte, assistir a um filme, ir a uma festa, etc. Contudo, não são as atividades em si que caracterizam o ócio, mas o resultado da vivência das mesmas. Ou seja, restringir o ócio somente aos conteúdos de algumas práticas representa um entendimento limitado acerca do seu verdadeiro significado, haja vista que uma atividade pode ter significados diferentes para diferentes pessoas. É fundamental que a atividade seja apreciada por aquele que a desempenha, já que o verdadeiro ócio é caracterizado pelo "modo de ser" e "sentir pessoal" de cada um.

Toda essa constatação torna-se uma preocupante, a partir do momento em que tais valores terminam por influenciar os saberes sobre o ócio, produzidos no nível do senso comum. Gomes (2007, p. 2) aponta que o senso comum é importante, todavia, "conceber o ócio seguindo apenas as referências do senso comum é um encaminhamento restrito porque nem sempre implica reflexão e análise criteriosa e crítica". O que se percebe, é que a sociedade atual, marcada pelo consumo, pelo individualismo, pela crise de sentido, pelo nível de estresse, pelos hábitos pouco saudáveis e pela perda de valores referenciais estáveis, ainda não está devidamente [in] formada acerca do verdadeiro significado do ócio, como também dos seus benefícios, dos seus valores e da sua importância para o desenvolvimento pessoal, social e econômico.

Essa primeira verificação nos obriga a uma reflexão um pouco mais aprofundada acerca do verdadeiro significado do ócio, ou seja, nos aponta para a necessidade de seguirmos para um pouco além do "senso comum".

\subsection{A revalorização do ócio: o resgatar de valores enriquecedores}

De acordo com Cuenca (2009), o entendimento do conceito de ócio ressurge na contemporaneidade como uma questão de limitada compreensão, mas que, todavia, representa um tema de significativa vitalidade e de extrema relevância no contexto atual, haja vista a amplitude do seu significado. O referido autor (investigador do Instituto de Estudos de Ócio da Universidade de Deusto, Espanha), influenciado pelo personalismo filosófico, vai introduzir na concepção de ócio o perfil humanista, que tem como ponto de referência duas declarações 
mundiais: a Carta sobre a Educação do Ócio de 1993, ratificada pelo conselho da World Leisure and Recreation Association (WLRA), e a Declaração de São Paulo de 1998.

Segundo Cuenca (2009, p. 70), ambos os documentos apontam o ócio "como um direito do ser humano, área específica da experiência, ambiente de liberdade com uma série de benefícios próprios, recurso de desenvolvimento pessoal e social, fonte de saúde e bem-estar". A Carta sobre a Educação do Ócio (1994) traz as seguintes considerações:

i. O ócio se refere a uma área específica da experiência humana, com seus benefícios próprios, entre eles a liberdade de escolha, criatividade, satisfação, desfrute e prazer, e uma maior felicidade. Inclui formas de expressão ou atividades amplas, cujos elementos são, frequentemente, tanto de natureza física como intelectual, social, artística ou espiritual;

ii. O ócio é um recurso importante para o desenvolvimento pessoal, social e econômico, além de um aspecto importante para a qualidade de vida. $\mathrm{O}$ ócio é também uma indústria cultural que cria empregos, bens e serviços. Os fatores políticos, econômicos, sociais, culturais e ambientais podem aumentar ou dificultar o ócio;

iii. O ócio promove a saúde e o bem-estar ao oferecer variadas oportunidades que permitem aos indivíduos e grupos selecionar atividades e experiências que se ajustam às suas próprias necessidades, interesses e preferências. As pessoas conseguem seu máximo potencial de ócio quando participam nas decisões que determinam as condições do seu ócio;

iv. O ócio é um direito humano básico, como a educação, o trabalho e a saúde, e ninguém deveria ser privado deste direito, fosse por razões de gênero, orientação sexual, idade, raça, religião, crença, nível de saúde, incapacidade ou condição econômica;

v. O desenvolvimento do ócio é facilitado quando assegurado pelas condições básicas da vida, tais como: segurança, moradia, alimentação, rendimentos, educação, recursos sustentáveis, igualdade e justiça social;

vi. As sociedades são complexas e estão inter-relacionadas, o ócio não pode desligar-se de outros objetivos vitais. Para conseguir um estado de bemestar físico, mental e social, um indivíduo ou grupo deve ser capaz de 
identificar e alcançar aspirações, satisfazer necessidades e interagir de forma positiva com o entorno. Portanto, se entende o ócio como recurso para aumentar a qualidade de vida;

vii. Muitas sociedades são caracterizadas pelo aumento da insatisfação, do estresse, do aborrecimento, da falta de atividade física, da falta de criatividade e pela alienação no dia-a-dia das pessoas. Todas estas características podem ser aliviadas mediante condutas de ócio;

viii. As sociedades em todo o mundo estão experimentando profundas transformações econômicas e sociais, que vem produzindo mudanças significativas na quantidade de tempo livre disponível ao longo da vida dos indivíduos. Estas tendências têm implicações diretas sobre várias atividades de ócio, às quais, por sua vez, influenciarão na procura e na oferta de bens e serviços de ócio (WLRA, 1994).

Nos dias atuais a proposta de revalorização do ócio e a construção de um referencial teórico acerca do seu verdadeiro significado vêm proporcionando a aquisição de um vasto conhecimento acerca da pessoa humana e esclarecendo inúmeras vivências e posicionamentos enquanto defesa da mesma. Cuenca e Amigo (2014, p. 11) apontam que "o ócio é um conceito e um setor significativo na nossa sociedade, tanto pela sua importância econômica como pela sua incidência nos estilos de vida atuais e na qualidade de vida pessoal e social". Ainda que 0 ócio não represente a "salvação da humanidade" ele não deixa de representar uma constituinte chave para se atingir o equilíbrio psicofísico. Nos reportar a essa maneira de experimentar o mundo, por meio de uma experiência de ócio, significa resgatar valores enriquecedores e sublimes da espécie humana. Quanto mais conhecimento e/ou informações acerca do ócio e dos seus valores para o sujeito e para a sociedade, maior será a nossa capacidade de compreendê-lo, buscá-lo e vivenciá-lo. Mediante Martins (2014, pp. 110-111):

Os estudos sobre o ócio representam a afirmação de um modelo aberto com aproximações epistemológicas e metodológicas múltiplas, baseadas em contínuas e diversas análises, métodos e recursos de diversas disciplinas que compartilham seu objetivo de conhecimento sobre esta temática. No entanto, em meio a esta interdisciplinaridade que envolve o ócio, trata-se de esclarecer o 
que compete ao campo específico de cada disciplina, na explicação e compreensão do fenômeno.

Os estudos sobre ócio têm uma conotação multidisciplinar que envolve a contribuição de várias áreas do conhecimento e o entendimento que cada investigador apresenta a partir de uma reflexão acerca das vivências de ócio na contemporaneidade. Por se tratar de uma condição da pessoa humana e de um fenômeno da sociedade, o ócio dificilmente poderia ser abordado a partir do ponto de vista de uma única disciplina. Os estudos multidisciplinares sobre o ócio vêm corroborar o seu valor e a sua importância, por meio de discussões e estatísticas que trazem amplas informações relacionadas com a economia, com os hábitos sociais, com o uso do tempo, com as preferências de atividades, etc., que apesar de relevantes, dificilmente permitem ter uma visão de conjunto.

A partir de uma abordagem investigativa, de reflexão multidisciplinar, as várias disciplinas têm levantado inúmeras questões acerca do ócio e dos seus atributos, com o objetivo de dar respostas globais e compreensíveis para os cidadãos. Deste modo, distintos autores vêm apontando a experiência de ócio como uma das mais importantes formas de expressão de liberdade, como uma experiência irrenunciável e como um "direito humano fundamental", que independe da etnia, da idade, da formação, da cultura, do status social, do gênero, da religião e das habilidades. O ócio é percebido hoje como um dos principais contributos para o desenvolvimento humano, como fonte de saúde e prevenção de enfermidades físicas e psíquicas, capaz de possibilitar experiências verdadeiramente satisfatórias e prazerosas, além de ser considerado um dos principais dispositivos para se discutir qualidade de vida e bem-estar, enquanto experiência que ajuda o ser humano a "ser", por meio da contemplação, criação e dignidade da vida como um bem inegociável. Como bem aponta a declaração da World Leisure and Recreation Association - WLRA, o ócio é uma experiência humana, básica e vital, é vivência e consciência, ação e contemplação.

Para o homem contemporâneo, tecnicista, materialista e angustiado, a prática do ócio tem um papel fundamental. A experiência de ócio é uma via de possibilidades de motivação, de aprendizagem, de conhecimentos inovadores e criativos, além de um tempo para repensar determinadas práticas e formas de 
relações no cotidiano. Por se tratar de uma experiência absoluta da personalização humana o ócio constitui um requisito indispensável, que pode dar respostas às grandes "crises de sentido" vividas pelo homem pós-moderno. É notória a necessidade que a sociedade vem demonstrando de [re] significar a vida, as relações humanas e a forma de ser e estar no mundo. O ócio, como aludiu a declaração redigida pelo conselho da WLRA, é um recurso capaz de contribuir para o desenvolvimento da personalidade, para uma individualidade saudável, para uma vida social equilibrada e, por conseguinte, para uma melhor qualidade de vida, tanto no âmbito pessoal como comunitário. Toda essa melhoria implica uma mudança de valores, de atitudes e de habilidades, como também a possibilidade de ampliar o conhecimento, aumentando a capacidade de aprender, de comunicar, de refletir e de viver.

A admissão da importância do ócio na contemporaneidade significa, pois, considerá-lo como uma vivência de valores imprescindíveis para o desenvolvimento humano e para a construção de uma realidade social mais justa e humanizada. Como bem afirma Martins (2014, p. 114), "saber o que é o ócio e sua função no todo existencial representa um pensamento alinhado ao afã do sujeito contemporâneo - não obstante, um sujeito exausto, imerso em um 'consumir sem sentido próprio', perdido no mundo das coisas".

\section{3- Tempo livre: um solo fértil para a expressão do ócio}

Num primeiro momento o conceito de "tempo livre" parece não exigir grande elucidação, contudo, por se tratar de um termo que remete a muitos equívocos buscaremos, com um olhar um pouco mais atento e rigoroso, uma delimitação do seu significado, a fim de clarificarmos um pouco mais o seu entendimento.

$\mathrm{Na}$ sociedade moderna a designação de tempo livre, apesar de ser considerado desde os antigos gregos, adquire relevo e torna-se uma referência temporal que implica uma divisão da unidade de tempo regulada pelo tempo de trabalho, tido como atividade central na organização da temporalidade social. Com o advento da sociedade industrial o tempo livre passou a ser percebido como "tempo de folga" e "tempo de férias", voltado para o descanso laboral, para 
o divertimento e para a manutenção do lazer ${ }^{27}$, porém, sem uma significação ou um sentido especial em si, simplesmente como um tempo voltado para a recuperação de energias para o retorno ao trabalho. De acordo com Aquino e Martins (2007, p. 490), "o tempo livre, tal como o concebemos hoje, adveio da natureza cronológica que atinge o apogeu pós-revolução industrial. É da liberação do tempo que devia ser dedicado ao trabalho que emerge a noção do tempo livre".

A reflexão sobre o conceito de tempo livre na contemporaneidade também nos aporta para o fenômeno da aceleração do tempo social. Essa realidade temporal, segundo Martins e Ponte (2010), tem levado o homem pós-moderno a viver em função do relógio, melhor dizendo, em função do tempo cronológico. Esse apressamento do ritmo social, que orienta o tempo da pós-modernidade, somado à sobrecarga de demandas e de obrigações de várias ordens, tem levado o homem contemporâneo à percepção de "dias cada vez menores" e à sensação de que "não Ihe sobra tempo para mais nada". Em virtude disso, o mercado tecnológico e do consumo vem buscando criar mecanismos "que marcam a busca incessante por mais tempo, porém, paradoxalmente, o homem termina por preencher esse tempo disponível com mais atividades e afazeres" (Aquino \& Martins, 2007, p. 481).

As necessidades econômicas e existenciais, face aos valores da atual sociedade tecnológica e do consumo, tem levado o homem contemporâneo a se dividir entre as obrigações impostas pelas atividades que assume e o desejo de libertar-se delas para poder usufruir de um tempo livre para si. Nos seus estudos, Martins (2014, p. 103) comenta que "no tempo social tomado pela ideia de aceleração, procura-se viver o máximo de experiências simultaneamente", fazendo do tempo presente a única dimensão temporal possível, o que resulta no empobrecimento dessas experiências (quase sempre impessoais, sem sentido aparente, voltadas para o interesse imediato) e no aumento da vida nervosa, ocasionando, com tudo isso, patologias como a ansiedade, o estresse, a fadiga, o aborrecimento e a depressão.

\footnotetext{
27 O tempo livre, a partir do seu viés industrial, dá passo também ao surgimento da compreensão do lazer, que passa a ser concebido como uma atividade que tem sua base ancorada na existência de um tempo livre, fomentado e reconhecido legalmente, e que poderia ser exercido autonomamente pelos trabalhadores, tendo por base sua condição socioeconômica e seus valores sociais (Aquino \& Martins, 2007, p. 491).
} 
A maior ou a menor variação desse tempo na vida dos indivíduos organiza-se e estrutura-se de acordo com padrões assimilados sobre como se deve dispor o tempo para as diversas atividades, além de como o sujeito valora o sentido do tempo cotidiano para si. Desta maneira, as diferentes formas de sentir, pensar, agir e estabelecer o tempo seguem padrões culturais que se refletem na ação do sujeito. (Aquino \& Martins, 2007, p.481)

Conforme Martins (2014), Frederic Munné, na sua obra intitulada Psicosociología del tiempo libre (1980), face às possibilidades de representação do tempo, expõe uma tipologia do tempo social que se revela através de quatro dimensões específicas: o tempo psicobiológico; o tempo socioeconômico; o tempo sociocultural; o tempo livre. De forma resumida, o tempo psicobiológico, como o próprio termo diz, é o tempo conduzido para as necessidades psíquicas e biológicas elementares, como por exemplo, o tempo de sono, de alimentação, de banho, de atividade sexual, etc., um tempo marcadamente individual. O tempo socioeconômico diz respeito ao tempo dedicado às atividades consideradas fundamentais, como as atividades domésticas, o estudo, o trabalho laboral ou qualquer outra demanda pessoal ou coletiva regida por valores sociais ou capitais, trata-se de um tempo amplamente heterocondicionado. Já o tempo sociocultural, é dedicado à socialização dos sujeitos, reportado para os compromissos sociais resultantes dos sistemas de valores e regras instituídos pela sociedade, esse tempo pode ser tanto heterocondicionado como autocondicionado. E a última categoria, o tempo livre, se refere às ações humanas, tempo que deveria ser preenchido com total autonomia subjetiva, liberdade e de maneira criativa. Consoante Munné, o tempo livre deveria ser um tempo de máximo autocondicionamento (percepção de mais autonomia subjetiva durante a realização de atividades) e mínimo de heterocondicionamento (menos autonomia subjetiva).

Consoante Martins e Ponte (2010, p. 81), alguns estudiosos defendem que a experiência de ócio só é possível ser pensada na esfera dos tempos livres, "pois neste intervalo temporal o sujeito apresenta uma disponibilidade pessoal (autocondicionamento) superior ao grau de imposições sociais (heterocondicionamento) que se observa nas relações de trabalho". Contudo, o ócio não pode ser identificado como tempo livre, apesar de ambos serem 
tomados como fazendo referência a um mesmo fenômeno social. Ócio e tempo livre são conceitos de natureza distinta. O tempo livre, por exemplo, ao contrário do ócio, não define a experiência humana em si.

\begin{abstract}
A identificação que se produziu entre ócio e tempo livre é produto dos estudos da sociologia do trabalho, difundidos de forma ampla, dissociados das outras possibilidades de apropriações às quais esta categoria está exposta. Tal fato dificultou a compreensão do ócio, pois a sociologia do trabalho não contempla a percepção psicológica. (Martins, 2014, pp. 111-112)
\end{abstract}

Segundo Cuenca (2009, p. 245), "dizer que se dispõe de tempo livre não é dizer muito, é só afirmar que se tem uma possibilidade de fazer algo de uma maneira livre e opcional", deste modo, não é possível assegurarmos que nos tempos livres residem o ócio, ainda que o tempo livre seja tomado como uma atividade. $O$ referido autor afirma que o ócio não é um tempo, mas uma vivência proporcionada por um estado mental que nos permite desfrutar de algo. $\mathrm{O}$ que seria então o tempo livre?

Martins (2014) esclarece que o tempo livre é uma referência temporal originária da liberação de obrigações, alusiva a um tempo de "não liberdade" ao qual se opõe, e cuja complexidade o faz confundir-se com ação. "A expressão 'tempo livre' se torna importante nesta relação por causa da palavra livre, que sugere um exercício humano voluntário de identidade, desejo, reconhecimento e autorreconhecimento" (Martins, 2014, p. 112). Neste sentido, o tempo livre pode ser referenciado como um tempo liberto de qualquer obrigatoriedade produtiva, voltado inteiramente para o indivíduo, para a sua satisfação e realização pessoal.

Erguido sob a égide da liberdade, é dentro do tempo livre que o ócio encontra um terreno fértil para a sua livre expressão. Como aponta Csikszentmihalyi ${ }^{28}$ (2000 como citado em Martins 2014, p. 139), "já que o tempo é o meio através do qual a vida se desdobra diante de nós, desperdiçar o tempo significa desperdiçar a nossa própria vida". Essa compreensão é fundamental,

${ }^{28}$ Csikszentmihalyi, M. (2000). Ócio y creatividad en el desarrollo humano. In: M. Csikszentmihalyi; M. Cuenca; C. Buarque \& C. Trigo et al. Ócio y desarrollo. Potencialidades del ocio para el desarrollo humano. Documentos de estudios de Ócio, 16. Bilbao: Universidad de Deusto, pp. 1732. 
pois se a partir da modernidade a denominação tempo livre adquire relevo e passa a ser mais difundida, a referência anterior, de uma forma geral, era o ócio, ou seja, este é que se opunha ao tempo de trabalho.

\subsection{0 conceito de ócio a partir de uma visão humanista}

Partindo do pressuposto de que não há consensos generalizados acerca do conceito de ócio, por se tratar de um tema complexo, abrangente e que nos remete a muitas possibilidades, buscaremos, a partir daqui, delimitar o seu significado a partir da perspectiva de ócio humanista, no qual trabalharemos esta tese.

Manuel Cuenca, investigador do Instituto de Estudos de Ócio da Universidade de Deusto ${ }^{29}$ (Espanha), influenciado pelo personalismo filosófico, introduziu na concepção de ócio o perfil humanista. Diferentemente do entendimento geral atribuído ao termo, Cuenca (2009) compreende o ócio como uma experiência gratuita, necessária e enriquecedora da natureza humana, voltada para o desenvolvimento pessoal. Segundo o autor, ócio é toda e qualquer ação relacionada com 0 mundo da subjetividade, da emotividade, do conhecimento, da reflexão, da contemplação e da criatividade. Trata-se de uma experiência integral e sobre-humana, que nos abre horizontes de conhecimento, compreensão e satisfação, pautada na liberdade, no prazer, no sentimento de felicidade e de bem-estar pessoal. Trata-se de uma experiência que faz parte do nosso jeito pessoal de ser, estar, sentir e manifestar, e que tem a ver com os nossos instintos, com os nossos sentidos em relação à vida e com os nossos valores pessoais e sociais. Segundo o autor, as características do ócio são "o amor, a sabedoria, a diversão nobre e uma abertura de ânimo que é inerente a toda criatividade. Sua constante é a reflexão como procedimento para aprofundar o sentido das ações e dos conhecimentos" (Cuenca, 2009, p. 114). Todos estes valores, de caráter e orientação positivos, que já se encontravam presentes no ócio clássico, são os mesmos reivindicados no ócio humanista.

${ }^{29} \mathrm{O}$ Instituto de Estudos de Ócio da Universidade de Deusto é considerado um polo de referência para as pesquisas acerca do ócio, pelos seus elevados níveis de especialização e leituras integradoras do fenômeno. 
De acordo com os pesquisadores da Universidade de Deusto, o ócio é uma experiência desvinculada da perspectiva da obrigatoriedade e desinteressada de qualquer atividade ou funcionalidade lucrativa, e que se diferenciará das demais experiências pela sua capacidade de sentido e potencialidade de encontros criativos. Essa experiência vai surgir da escolha, da identificação, da abertura, da entrega, da apreciação e da percepção daquele que a vivencia, independentemente da atividade em si, da duração do tempo, do seu nível econômico e da sua formação.

Segundo Cuenca (2009), o ócio pode ser casual, ou seja, pode ser uma atividade simples com uma compensação imediata, que não requeira uma formação específica para o seu desfrute. Mas geralmente o ócio é resultado de um atrativo, cuja experiência requer uma preparação prévia por parte do sujeito. Tanto a preparação como a prática do ócio devem possibilitar ao participante adquirir habilidades e conhecimentos nos mais diferentes graus. A este tipo de ócio Cuenca denomina de ócio sério ou substancial. O mais importante, segundo o autor, é percebermos que a experiência de ócio só ganha significado, relevância e qualidade na medida em que deixamos de vivê-la como "mero lazer" ou "mero passatempo", vazio de significado, rotineiro e monótono. Uma experiência de ócio deve possibilitar uma somatória de vivências dentro de um processo que faz parte da maturescência humana, e que está relacionado com o estado psicofísico e com os valores de cada um. Deste modo, o ócio irá atuar como uma motivação que impulsiona o sujeito para a "ação", cujo resultado será a sua satisfação psicológica. Esta satisfação é o aspecto emocional que se torna mais evidente quando se produz um ajuste entre as expectativas da pessoa e sua vivência de ócio real.

Cuenca e Amigo (2014, p. 17) apontam que "o ócio não é um tempo, nem algumas atividades às quais damos esse nome, mas sim uma ação pessoal e comunitária que tem a sua raiz na motivação e na vontade". O termo ócio é sinônimo de ocupação desejada, satisfatória, prazerosa, escolhida livremente, realizada sem nenhuma obrigatoriedade, livre de qualquer aprisionamento e com fim em si mesmo, e que se manifesta em qualquer dimensão desinteressada da vida humana, seja ela lúdica, ecológica, criativa, festiva ou solidária. Trata-se também de uma experiência que pode encontrar seu sentido na contemplação e reflexão de um tempo voltado para reviver boas recordações de momentos que 
proporcionaram finais felizes, trazendo à tona sentimentos que irão se converter em motivação para um novo processo existencial.

Nos seus estudos Cuenca (2009) destaca a função preventiva do ócio. Conforme o autor, o ócio tem efeitos benéficos para a preservação da saúde e para a qualidade de vida comunitária, e pode contribuir para a redução dos gastos destinados a doenças ou problemas que poderiam ser diminuídos quantitativamente ou qualitativamente, e até mesmo evitados. Como exemplo o autor aponta o abuso do álcool, das drogas e dos jogos compulsivos, como também a delinquência juvenil e os conflitos familiares e comunitários. Muitos destes problemas surgem em decorrência do uso inapropriado e sem sentido do ócio, como também da falta de condições básicas da vida, tais como: a segurança, a moradia, a alimentação, os rendimentos, a educação, os recursos sustentáveis, a igualdade e a justiça social, causadas pelo estilo de vida pósmoderno. Daí a necessidade de uma intervenção educativa, de se incluir nos programas de educação para a saúde uma reflexão sobre a importância do cultivo do ócio, lembrando que a relação entre ócio e saúde não decorre somente do ponto de vista da prevenção, já que o ócio adquire também uma função terapêutica, de meditação, de descanso, de criação e de diversão ${ }^{30}$.

O ócio é, portanto, percebido como um recurso capaz de melhorar a qualidade de vida das pessoas, além de se tratar de um "corretivo" equilibrador de outros desajustes e carências do tipo pessoal e social. Falar de ócio na atualidade é falar de uma vivência integral, de sentido de vida, de ocupação voluntária, de satisfação, de saúde, de bem-estar pessoal, de desenvolvimento pessoal e comunitário. Falar de ócio é falar de uma vivência relacionada com o sentido da vida e com os valores de cada um. É falar também de uma experiência que nos leva a perceber a vida como algo positivo de finalidade e sentido, de algo que proporciona a autoexpressão, o enriquecimento cultural e a escuta sensível de si e do outro, e que estimula estados de ânimos positivos, a união familiar e comunitária. Se o ócio, como tudo indica, é uma constituinte chave para se atingir o equilíbrio psicofísico, podemos pensar que a vivência subjetiva do ócio, nas

\footnotetext{
${ }^{30} \mathrm{Na}$ atualidade, o aumento das doenças cardiovasculares ou degenerativas não tem muito a ver com o aumento da expectativa de vida, ao contrário, "se reconhece que são consequências dos efeitos negativos do ambiente, da urbanização, do crescimento do nível de estresse na vida das cidades e outros hábitos próprios da vida moderna (Cuenca, 2009, p. 79)". Se visto desta forma, as experiências de ócio surgirão não só como alternativa, mas também como uma forma preventiva e extremamente necessária para a manutenção do equilíbrio físico e mental humano.
} 
suas mais variantes possibilidades, seria um dos caminhos mais eficazes para se atingir ânimos positivos, dado a somatória de experiências dentro de um processo que faz parte da maturescência e do desenvolvimento humano.

$\mathrm{Na}$ contemporaneidade vários estudiosos vêm apontando a experiência de ócio como uma das mais importantes formas de expressão de liberdade, como uma experiência irrenunciável e como um direito humano fundamental. O ócio é percebido hoje como um dos principais contributos para o desenvolvimento humano, como fonte de saúde e prevenção de enfermidades físicas e psíquicas, capaz de possibilitar experiências verdadeiramente satisfatórias e prazerosas, além de ser considerado um dos principais dispositivos para se discutir qualidade de vida e bem-estar pessoal, enquanto experiência que ajuda o ser humano a "ser", por meio da contemplação, da criação e da dignidade da vida como um bem inegociável. Como aponta Cuenca (2009), face a uma sociedade caracterizada pelo estresse, pelo tédio, pela insatisfação, pela falta de criatividade e alienação, o ócio seria uma experiência capaz de ajudar o indivíduo a se realizar, a se conhecer, a se identificar, a se sentir melhor, a sair da rotina, a fantasiar e a recuperar o equilíbrio das frustrações e dos desenganos.

\subsection{Elementos essenciais para a compreensão do Ócio Humanista}

Na sua obra, Ócio Humanista: dimensiones y manifestaciones actuales del ocio (2009), Manuel Cuenca, a partir das reflexões de Kriekemans ${ }^{31}$, agrupa quatro características, que segundo ele, são essenciais para a compreensão do ócio humanista: a vivência lúdica; a liberação; o autotelismo; e a formação.

De acordo com o referido autor, Kriekemans considera que a vivência da dimensão lúdica do ócio é uma necessidade da condição humana que faz parte do processo de personalização do sujeito. Kriekemans (1973 como citado em Cuenca 2009, p. 64) aponta que "no jogo verdadeiro nos acercamos do mundo de um modo diferente do que fazemos em nossa vida habitual", ou seja, no jogo conferimos ao mundo uma significação diferente da realidade, uma significação de fantasia. Mais que o jogo em si mesmo, tal como acontece na fase da infância,

31 Kriekemans, A. (1973). La Educación del empleo de los ocios, en Pedagogía General. Barcelona: Herder. 
Kriekemans faz menção à vivência da dimensão lúdica da vida. "Portanto, os jogos não devem limitar-se somente a uma etapa da vida, senão fazer parte de toda a nossa existência" (Cuenca, 2009, p. 66). O jogo, o lúdico, o imaginário, a fantasia, a partir da prática de atividades recreativas e criativas, nos distancia da crua realidade cotidiana e nos reporta para um mundo distinto, no qual, segundo Kriekemans, "podemos voltar a sermos nós mesmos e obter forças para podermos enfrentar as exigências do mundo cultural contemporâneo" (1973 como citado em Cuenca 2009, p. 66).

A vivência lúdica do ócio nos ensina a sermos mais humanos, nos ajuda a resgatar a criança adormecida que existe em cada um de nós. O lúdico, além de aprimorar a nossa percepção e contribuir para o nosso desenvolvimento pessoal, seja ele intelectual, social, físico, mental ou espiritual, nos devolve a nossa liberdade e a nossa alegria de espírito, que são estados inteiramente responsáveis pela nossa satisfação e realização pessoal. Conforme Cuenca (2009, p. 66), "a vivência lúdica do ócio é uma necessidade para nossa autorrealização e deve formar parte do processo de personalização de cada um", ela é essencial para acedermos ao mundo da fantasia, do imaginário e para introduzirmos a alegria no nosso cotidiano.

Uma segunda característica, fundamental para o entendimento do ócio, é a sua dimensão libertadora. A liberdade, segundo Cuenca (2009), não pode ser uma liberdade condicionada, mas sim uma liberdade percebid $a^{32}$ pelo próprio sujeito. "A realização do ócio pessoal, não manipulado, não é outra coisa senão o exercício da nossa liberdade, a afirmação de uma vida liberada de obrigações e, inclusive, da opressão do tempo" (Cuenca, 2009, p. 67). A experiência real de liberdade é que nos permite relacionar de uma maneira mais altruísta e lúdica com o meio, possibilitando-nos recriar o nosso ambiente e transformá-lo num espaço de criação, de conhecimento, de alegria, de beleza e de realização do amor.

\footnotetext{
${ }^{32} \mathrm{~A}$ liberdade percebida faz referência à sensação, se a experiência é real ou não. É também algo que é feito por livre escolha e, porque a pessoa deseja fazer. (...) Uma coisa é fazer algo porque tem que fazê-lo, outra porque se escolheu e se quer fazer. Por isso, não é possível chamar de experiência de ócio uma vivência onde a pessoa se sente ameaçada ou tolhida na sua capacidade de escolha e no exercício da liberdade. Afinal, a reação motivacional que o indivíduo experimenta na liberdade para realizar uma ação é um fator que limita e determina o resultado da experiência vivida (Francileudo, 2009, p. 222).
} 
Outra particularidade, talvez a mais importante para a compreensão do ócio, é o autotelismo, isto é, a experiência do ócio em si mesmo. Tradicionalmente, a prática do ócio é percebida como um meio para se descansar e recuperar as forças para retornar ao trabalho. O ócio não se justifica pelo trabalho e vice-versa, são duas áreas vitais, porém, diferenciadas. São duas áreas complementares, mas não obrigatoriamente interdependentes. É importante percebermos que $o$ trabalho é simplesmente um meio para se garantir a subsistência, sem desconsiderar a sua importância, tanto para a sociedade quanto para a formação identitária, social e psicológica do indivíduo. Já o ócio, entendido no seu sentido mais puro, "é um fim em si mesmo, busca a realização de algo sem pretender outra coisa em troca da ação" (Cuenca, 2009, p. 68). O ócio autotélico é uma experiência libertadora, contemplativa, capaz de propiciar momentos de reflexão e de liberdade, de forma satisfatória e realizadora. Trata-se de uma vivência de caráter desinteressado e que presume o desprendimento e a independência no que diz respeito aos interesses e valores da vida cotidiana. Segundo o referido autor, uma formação adequada sobre os valores e os fins no qual se fundamenta o ócio autotélico nos levaria a uma outra forma de percepção do outro, da vida e do mundo. "As experiências autotélicas de ócio com uma direcionalidade positiva, beneficiosas para o desenvolvimento pessoal e social, abre a consciência para a experimentação de novas oportunidades do ser que se constitui em metas de aperfeiçoamento" (Cuenca, 2009, p. 94).

Uma educação voltada para o exercício do ócio seria outro elemento essencial para a sua compreensão. A formação para o ócio concede ao indivíduo uma mudança de valores, atitudes e habilidades capazes de contribuir para o desenvolvimento da personalidade, para uma individualidade saudável, para uma vida social equilibrada e, por conseguinte, para uma melhoria na qualidade de vida. Este processo formativo propiciaria novos horizontes, capazes de converter o ócio num fator de desenvolvimento humano. A formação para o ócio reside na preparação dos sujeitos, para que não se adaptem a um ócio orientado somente para o entretenimento ou diversão, indicando o acesso a experiências de ócio que os introduzisse em processos de melhoria e de crescimento pessoal. Cuenca (2009, p. 64) salienta que a experiência humanista do ócio deve ser "uma vivência integral e relacionada com o sentido da vida e os valores de cada um, coerente com todos eles. A formação facilita esse processo, fazendo ver que a educação 
do ócio não se refere só à infância, mas que afeta a todas as idades". A educação para o ócio seria "o melhor antídoto para suportar os embates da propaganda, dos impulsos da moda e os estragos de uma vida precipitada e irreflexiva" (Cuenca, 2009, p. 69). Nos seus estudos Aquino e Martins (2007, p. 483) apontam que:

\begin{abstract}
A educação costuma sonegar o direito ao ócio; observa-se que as escolas tendem a preparar a criança para a importância da profissão e do trabalho no futuro, isto é, preparam crianças e jovens para a vida adulta moldada pelo trabalho, porém não há orientação nesse processo para o uso adequado do tempo de ócio, um fator de vital importância para a edificação de um indivíduo equilibrado. Isso porque a escola, dentro de uma concepção moderna, está profundamente demarcada pelo paradigma da produção industrial, reiterando que a atividade social dominante e determinante da configuração social é o trabalho.
\end{abstract}

Face à importância do ócio, como preparar a geração atual e as novas gerações para a sua compreensão e para a sua vivência? Cuenca (2009) comenta que H. Dimock ${ }^{33}$, em 1941, já apontava quatro princípios básicos para uma educação sobre o ócio. O primeiro princípio seria o da continuidade, visto que o ócio está intrinsecamente ligado à nossa vida, forma parte da nossa existência total, é um contínuo ou uma extensão que nos acompanha do nascimento à morte. $\mathrm{O}$ segundo princípio faz alusão à globalidade, visto que o ócio não é somente jogo, cultura, hobbies ou festas. Quando desenvolvemos um ócio pluridimensional, de repercussão física, intelectual e social, estamos optando por um ócio mais maduro e humano. Outro princípio, também importante, é a diversidade de interesses, pois se a experiência de ócio não estiver enraizada na convicção, no universo interior e na personalidade, dificilmente poderá ser considerada uma vivência de ócio em si mesma. O último princípio ou critério, apontado por Dimock, é a prática do ócio voltada para uma ação ativa, positiva e criadora. Segundo Cuenca, $\mathrm{H}$. Dimock também nos alerta sobre a necessidade e a importância da prática do ócio compartilhado, supraindividual, que se engrandece a partir de encontros compartilhados com outros indivíduos.

33 Dimock, H. (1941). Rediscovering the Adolescent. Nueva York, pp. 56-60 


\section{6- A expressão do ócio enquanto vivência grupal e compartilhada}

A vivência de ócio quase sempre é resultante do estilo pessoal de vida, dos interesses pessoais, dos valores e da forma de ser e estar de cada indivíduo perante a vida e o mundo. Todavia, aponta Cuenca (2009), embora o ócio seja entendido como uma expressão de interesses individuais, quando compartilhado sua vivência pode transcender o pessoal e adquirir uma importância social e até mesmo comunitária. Do ponto de vista comunitário o ócio irá possibilitar a integração social, o equilíbrio dentro de uma relação grupal e o desenvolvimento de laços afetivos, que podem variar desde uma preocupação com o outro, demonstrada de maneira desinteressada, até a construção de vínculos fortemente afetuosos, com uma incidência benéfica para toda a comunidade, além de levar os sujeitos a desenvolver e vivenciar valores que são fundamentais em múltiplos campos da vida pessoal e social. Aquino e Martins (2007, p. 495) comentam que nos dias atuais as condições de trabalho, a urbanização intensa e os novos modos de vida "geraram um empobrecimento da comunicação interpessoal e, consequentemente, um isolamento que, no ócio, encontra um contraponto". Quando a experiência de ócio é compartilhada estabelece-se relações interpessoais e oportuniza-se a socialização.

As possíveis manifestações do ócio, a partir de uma vivência grupal e compartilhada, podem contribuir para que o grupo viva e compartilhe experiências satisfatórias e felizes. Tais manifestações são muitas vezes determinadas pelo grupo que as experimenta. Estas manifestações estão enraizadas na tradição e na cultura desenvolvida dentro da própria comunidade ${ }^{34}$, sendo expressão dos indivíduos que constituem o grupo e que se desenvolvem a partir da livre iniciativa. Quando a experiência é compartilhada, a expressão, que muitas vezes parte de uma iniciativa individual, logo é endossada e consentida pelo grupo, como manifestação de uma coletividade.

\footnotetext{
${ }^{34} \mathrm{O}$ ócio de uma comunidade se nutre de suas iniciativas e de sua tradição, mas também do momento histórico, da realidade global que a circunda, com suas modas e preferências; junto às iniciativas do tipo institucional que, a curto ou largo prazo, podem incidir nos hábitos de ócio dos cidadãos (Cuenca, 2009, p. 97).
} 
As várias manifestações do ócio numa comunidade, quando positivas, podem ser analisadas a partir das dimensões do ócio autotélico. De acordo com Cuenca (2009), o ócio autotélico é o verdadeiro ócio, o "núcleo essencial", a "luz que ilumina". Trata-se de uma experiência vital, voltada para o desenvolvimento humano, e que repousa sobre três pilares essenciais para a sua realização: a liberdade de escolha, a experiência de ócio em si mesmo e a sensação gratificante. Consoante o referido autor, diferentemente de outras experiências, o ócio autotélico, de algum modo, pode se realizar através de cinco dimensões, que são: a dimensão lúdica; a dimensão criativa; a dimensão festiva; a dimensão solidária; e a dimensão ambiental/ecológica. Estas cinco dimensões irão se relacionar com as diferentes formas de se viver o ócio, como também com os diversos espaços, ambientes, recursos e equipamentos disponíveis. A caracterização e diferenciação de cada uma dessas dimensões resultam do interesse e do valor atribuído por cada indivíduo, ou seja, compreende tanto as necessidades pessoais específicas como também os "estilos de vida de ócio", desde as escolhas que fazemos até como executá-las. Os chamados "estilos de vida de ócio" não são outra coisa senão um conjunto de hábitos, costumes, procedimentos e atitudes, que discernem os sujeitos e as distintas comunidades, e que terminam por definir os seus modelos de ócio.

A dimensão lúdica do ócio comunitário referencia o modo como distintas comunidades desenvolvem, praticam e vivenciam suas atividades recreativas. Responde à forma como as pessoas se divertem nas diferentes fases da vida, aos espaços, ambientes e meios, ao modo como são estabelecidas as relações entre as pessoas e os grupos, aos apoios institucionais e aos vínculos que se estabelecem a partir destes.

A dimensão criativa do ócio comunitário toma como alvo as experiências formativas e culturais de ócio, ligadas a processos de criação e reflexão, e às possibilidades de comunicação e abertura, como as práticas ou atividades teatrais, musicais, plásticas, literárias, folclóricas e artesanais, entre outras. É uma dimensão que está estreitamente relacionada com a cultura dos indivíduos, dos grupos e da comunidade, sendo manifestação de sentimentos, de estados de espírito, de ideias, de impressões, de modos de vida e de pontos de vista, muitas vezes de abordagem ética e moral. 
A dimensão festiva do ócio comunitário faz alusão às manifestações festivas, enquanto experiências eminentemente grupais, compartilhadas e de caráter social. É uma dimensão com enorme poder de coesão comunitária, que nos permite visualizar e perceber a comunidade de uma forma diferente da habitual, oposta da vida rotineira. Mediante Cuenca (2009, p. 99), "não é de estranhar, portanto, que, conhecida sua incidência, seja um tipo de ócio especialmente cuidado pelas instituições públicas".

A dimensão solidária do ócio comunitário fala de um ócio entendido como vivência social e altruísta, ou seja, fala da participação em práticas ou atividades dedicadas ao outro, de maneira desinteressada e sem esperar nada em troca. A vivência solidária do ócio nos entrelaça com a vida dos outros, é um signo de humanização e de amor ao próximo, além de representar um potencial capaz de levar a comunidade à realização de ações sublimares, fundamentadas no compromisso e na responsabilidade para com o bem-estar do outro.

A dimensão ambiental-ecológica do ócio comunitário está relacionada com o entorno físico e urbano da comunidade, com a preservação do patrimônio e com a conservação do ambiente natural (jardins, parques, etc.). Nos seus estudos Cuenca (2009) nos alerta da relação que se estabelece entre as práticas do ócio e a natureza (bastante habituais nos finais de semana), como também da importância do trabalho de conscientização e sensibilização por parte da comunidade, sobre os impactos das atividades de ócio e da importância do planejamento de um desenvolvimento sustentável que respeite o meio ambiente.

De acordo com o autor supracitado, todas estas dimensões do ócio podem ser percebidas como "pontos de referência", tanto para o desenvolvimento pessoal como para o desenvolvimento comunitário. Dificilmente encontraremos comunidades em que, de uma maneira ou de outra, não apareçam todas essas dimensões. Relacionadas com as diferentes formas de se viver o ócio, essas dimensões nos ajudam a analisar, compreender e planificar o ócio em toda a sua complexidade. 


\section{7- Ócio lúdico: a diversão como função regenerativa e compensatória}

A dimensão lúdica do ócio, como já foi referida, é uma característica essencial para a compreensão do ócio humanista. Ela está relacionada com a forma como as pessoas ou comunidades desenvolvem, praticam e vivenciam as atividades voltadas para o descanso e diversão. Descanso, interpretado como interrupção do trabalho, e diversão, como ação que entretém, voltada para a evasão mental e promoção da alegria.

De acordo com Cuenca (2009), uma das funções menos discutidas acerca do ócio é a sua função regenerativa. O referido autor assinala que é necessário [re] compensarmos o cansaço com o descanso, do contrário o sujeito terminará por sofrer danos na sua saúde, pois descansar é reestruturar as energias físicas e psíquicas, é voltar ao estado anterior, ao estado de "não cansaço". Segundo leda Rhoden (2014), existem três formas conhecidas de descanso: a substituição de uma atividade por outra; o relaxamento consciente; e o sono profundo. Mediante a autora, as duas primeiras formas de descanso ajustam-se perfeitamente ao ócio, contrapondo o sono profundo, que pode ser considerado como uma necessidade biológica natural, como um tempo para reposição de energia, nunca como uma experiência de ócio. Dessas três formas, a substituição de uma atividade por outra seria a estratégia mais simples na busca pelo descanso efetivo, o que nem sempre resulta, proporcionando simplesmente uma sensação de alívio imediato.

As substituições mais comuns, conscientes ou inconscientes, classificam-se da seguinte maneira: a substituição de uma atividade mental por outra de tipo físico ou emocional (descanso mental); a substituição de uma atividade emocional-afetiva por uma atividade mental ou física (descanso da sensibilidade) e a substituição de uma atividade física por outra de caráter afetivo ou mental (descanso do corpo). Para que essas estratégias funcionem é necessário que as lembranças e imagens originárias da atividade anterior não se misturem com a nova atividade, o que pode resultar uma tarefa difícil para algumas pessoas sobrecarregadas de estimulação. (Rhoden, 2014, p.6) 
Manuel Cuenca (2009) comenta que Weber (1969), na sua obra intitulada "O problema do tempo livre" 35 , já diferenciava dois tipos básicos de descanso, que são: o descanso ativo e o descanso passivo. Conjuntamente, um e outro ajudam a delimitar o papel do ócio e a revalorizar a sua dimensão lúdica. O descanso passivo é um descanso extremamente necessário para a reestruturação física, é sinônimo de inatividade, de falta de ação, de repouso físico, e encontra o seu lugar quando o indivíduo opta por não fazer absolutamente nada, permanecendo em estado de inércia. Em contrapartida, o não fazer nada pode transformar-se em uma necessidade de se realizar alguma coisa, uma atividade que fosse compensatória, contrária ao repouso físico. Já o descanso ativo, é um descanso necessário para a regeneração mental, é sinônimo de atividade, de ocupação desejada, e encontra o seu lugar quando o indivíduo desenvolve uma ação que Ihe seja prazerosa e satisfatória. Neste caso, a diversão seria o seu principal ponto de referência, já que ela é capaz de libera-lo do cansaço mental, da monotonia e do tédio, possibilitando uma fuga do cotidiano. "É por isso que o ócio, enquanto diversão, enquanto evasão lúdica da realidade cotidiana, tem uma função necessária e positiva na vida da pessoa" (Cuenca, 2009, p. 101).

Já a diversão é uma necessidade da condição humana, e que faz parte do processo de personalização de cada um. A diversão representa a evasão compensatória que nos permite restaurar o equilíbrio físico, psíquico e emocional, além de um meio para suportar as pressões sociais. Consoante Rhoden (2014, p. 7), a busca de compensação por meio do divertimento "se orienta para atividades concretas caracterizadas por mudanças de lugar, de ritmo e de estilo de vida, ou por meio de atividades fictícias apoiadas em projeções ou fantasias - no sentido de defesa psíquica - ou em simples recursos do imaginário". Divertimos-nos por meio de práticas ou atividades ocorridas como forma de lazer, tais como: jogos individuais ou coletivos, brincadeiras, hobbies, passatempos, viajando, dançando, jogando peteca ou quebra-cabeças, assistindo a um filme, lendo um livro, ouvindo uma música, etc. O divertimento aponta para a forte relação do ócio com as reivindicações urgentes e próprias da vida pós-moderna, como por exemplo, evadir-se da realidade cotidiana, esquecer-se temporariamente de alguma situação, limpar a mente de sentimentos negativos e desagradáveis, afastar-se

${ }^{35}$ Weber, E. (1969) El problema del tiempo libre. Madrid: Editora Nacional. 
dos problemas ou expurgar-se no sentido catártico. A diversão, neste sentido, cumpre a função de desvio de atenção de um cotidiano quase insuportável para uma dimensão oposta da vida rotineira.

\begin{abstract}
Romper com a monotonia da rotina, com forças inibidoras, limitações externas a autoexpressão e com fontes de dor e sofrimento, pode ser necessário e conveniente para a saúde e para a integridade pessoal, embora seja uma necessidade produzida pelo estilo de vida da sociedade pós-moderna. As estratégias podem variar, desde a tentativa de "não pensar"; pensar somente no que não exige esforço mental ou emocional (distrair-se); ocupar-se com algo muito diferente ao rotineiro (entreter-se); mudar de ambiente, estilo e ritmo (evadir-se); deixarse absorver por coisas ou eventos distintos (romper), etc. Todas essas formas de distração podem se transformar em experiências pessoais de ócio construtivo, desde que não aconteçam em estados de dissociação da personalidade, de alienação e perda de identidade. (Rodhen, 2014, p. 8)
\end{abstract}

A necessidade imprescindível de descanso e diversão quase sempre termina por influenciar o indivíduo na escolha do seu ócio, levando-o, muitas vezes, a optar por aquelas atividades que não demandam grandes esforços, seja no plano físico ou mental. Com tudo isso, o que mais acontece é o distanciamento daquilo que poderia representar uma verdadeira experiência de ócio, capaz de possibilitar o desenvolvimento humano, a autorrealização e a satisfação pessoal.

\title{
2.8- A ação lúdica: o jogo como atividade necessária à manutenção da vida
}

O termo jogo, do latim incus, quer dizer diversão, brincadeira. As definições mais gerais que encontramos nos dicionários de língua portuguesa são: exercício ou divertimento sujeito a certas regras; passatempo; divertimento público composto de exercícios esportivos. O termo jogo é utilizado para definir não só uma atividade individual, mas também atividades em grupo. Os estudos acerca do jogo e da sua importância para a promoção humana apontam que, mais que um modo de preencher o tempo, o jogo tem raízes profundas no que diz respeito ao desenvolvimento físico, psíquico e intelectual humano, ou seja, à vida. 
Segundo o filósofo Huizinga (2000), jogar é uma atividade social fundamental, uma categoria absolutamente primária da vida, um elemento lúdico que está na base do surgimento e desenvolvimento das civilizações. Na sua obra Homo Ludens, o referido autor aponta que o jogo é um complemento e, em última instância, uma parte integrante da vida em geral. $O$ jogo ornamenta e amplia a vida, tornando-se uma necessidade vital, tanto para o indivíduo quanto para a sociedade, dado ao sentido que encerra, ao seu valor expressivo, à sua significação e às suas associações sociais e espirituais, enquanto função cultural. O jogo é percebido como prática para se ocupar o tempo, como recreação ou diversão. Mais a mais, o jogo tem uma função biológica, do ponto de vista pessoal, e uma função cultural, do ponto de vista social e comunitário.

Conforme o autor supracitado, de uma forma simplificada e generalizada, jogar é um procedimento lúdico, com fins recreativos, praticado nas horas de ócio. Trata-se de uma atividade ou ocupação voluntária, dotada de um fim em si mesmo, livre, inútil, gostosa, repetível, capaz de produzir um estado de exaltação e alegria. Jogar é uma qualidade de ação bem determinada e distinta da vida comum, cuja finalidade ultrapassa a esfera da vida humana. É uma ação que se faz possível num espaço/tempo específico ${ }^{36}$, limitado, com uma organização préestabelecida, com regras bem específicas e obrigatórias ${ }^{37}$, que impõem ordem, tensão, incerteza e alegria à ação lúdica ${ }^{38}$. O jogo não é vida corrente, pelo contrário, é um mundo efêmero dentro de um mundo habitual, que possibilita a evasão da vida real para uma esfera temporária de atividade. No jogo sempre existe "alguma coisa em jogo" que ultrapassa as necessidades humanas, conferindo um sentido à ação, um significado. "Reconhecer o jogo é, forçosamente, reconhecer o espírito, pois o jogo, seja qual for sua essência, não é

\footnotetext{
${ }^{36}$ A limitação no espaço é ainda mais flagrante do que a limitação no tempo. Todo jogo se processa e existe no interior de um campo previamente delimitado, de maneira material ou imaginária, deliberada ou espontânea. (...) A arena, a mesa de jogo, o círculo mágico, o templo, o palco, a tela, o campo de tênis, o tribunal etc., têm todos a forma e a função de terrenos de jogo, isto é, lugares proibidos, isolados, fechados, sagrados, em cujo interior se respeitam determinadas regras (Huizinga, 2000, p. 11).

${ }^{37}$ Estas regras são um fator muito importante para o conceito de jogo. Todo jogo tem suas regras. São estas que determinam aquilo que "vale" dentro do mundo temporário por ele circunscrito. As regras de todos os jogos são absolutas e não permitem discussão (Huizinga, 2000, p. 12).

38 O jogo é "tenso", como se costuma dizer. É este elemento de tensão e solução que domina em todos os jogos solitários de destreza e aplicação, como os quebra-cabeças, as charadas, os jogos de armar, as paciências, o tiro ao alvo, e quanto mais estiver presente o elemento competitivo mais apaixonante se torna o jogo. Esta tensão chega ao extremo nos jogos de azar e nas competições esportivas (Huizinga, 2000, p. 12).
} 
material. Ultrapassa, mesmo no mundo animal, os limites da realidade física" (Huizinga, 2000, p. 7).

Cuenca (2009, p. 113) observa que "a ação lúdica diverte quando nos adentramos na dinâmica do jogo e em sua lógica interna porque, por ser tão diferente da lógica diária, nos separa e nos liberta da realidade, impulsionando a capacidade criadora". Movido por um estado de liberdade e êxtase o indivíduo é levado a vivenciar um mundo diferente, lúdico, imaginativo, distinto do mundo real, desenvolvendo, a partir daí, outras percepções e conhecimentos acerca de si e do mundo. É pelo menos assim que, em primeira instância, o jogo nos apresenta, como um intervalo em nossa vida cotidiana, como uma atividade lúdica que transcende as necessidades e os desejos e que se desenvolve em função da satisfação que é produzida a partir da sua prática, a saber, uma satisfação que consiste nessa própria realização.

Segundo o referido autor, a liberdade seria uma das principais características do jogo, ainda que este fosse desenvolvido num espaço/tempo limitado e com regras mais ou menos pré-estabelecidas. $\mathrm{O}$ jogo sempre tende a criar um campo de liberdade, de opções sempre novas, dentro de um canal de possibilidades. Esse estado de liberdade, atingido atraves do jogo, nasce da necessidade de se unir entretenimento e fantasia. Huizinga (2000) comenta que os jogos infantis, por exemplo, têm a qualidade lúdica em sua própria essência. As crianças brincam porque gostam de brincar, e é precisamente em tal fato que reside a liberdade. Seja como for para os adultos, ao contrário das crianças, o jogo é uma função que poderia ser facilmente dispensada, é algo desnecessário, supérfluo, que só se torna um desejo na medida em que o prazer proporcionado por ele se transforma numa necessidade.

O jogo realmente não tem finalidade alguma, por isso se considera parte do ócio autotélico. A falta de finalidade faz com que seja difícil precisar o seu valor por si só. Mas sim, é inquestionável sua função de ruptura com o mundo sério e, consequentemente, sua função de relaxamento e descanso. (Cuenca, 2009, p. 105) 
Conforme Cuenca (2009), essa concepção de Huizinga é um modo de se entender o significado do ócio. $\mathrm{O}$ jogo, como o ócio autotélico, é algo desinteressado, o que não quer dizer que não seja valioso, ao contrário, é algo essencial para a promoção e desfrute das emoções. Como o jogo, o ócio também é uma atividade livre, voluntária, gostosa e inútil, que se desenvolve dentro de um limite espaço-temporal restrito e com uma organização determinada. Trata-se de uma ação que se enquadra no mundo das emoções, dos afetos e do imaginário, e cuja vivência está estruturada na satisfação, no prazer, no sentimento de felicidade e liberdade. Esta última, a liberdade, provoca um sentimento de plenitude e gozo, porque favorece a vivência da alegria. Deste modo, o ócio autotélico se distancia do mero "passatempo" e adquire uma função de desfrute, de descanso e de evasão.

Kriekemans $^{39}$ (1973 como citado em Cuenca 2009, p. 57) vai considerar a vivência da dimensão lúdica do ócio como algo essencial, visto que "no jogo verdadeiro nos acercamos do mundo de um modo diferente do que nós fazemos em nossa vida habitual. Nele se atribui ao mundo uma significação distinta da sua realidade". O mesmo autor vai dizer ainda que "o ócio é uma 'recriação', ou seja, um meio para restabelecer a vontade e o valor de viver (1973 como citado em Cuenca 2009, p. 64)." Aqui, o termo "recriação" vai adquirir um sentido muito mais profundo que entretenimento, diversão ou alegria, podendo ser entendido como uma ação, cujo significado seria a de "criar" ou "produzir algo de novo".

Um ócio que "recria", que dá vida, não pode ser uma experiência superficial, deve estar ancorado na vida interior e com base nos valores. (...) A vivência de ócio capaz de recriar a vida em quem a experimenta, é, essencialmente, uma vivência de ócio compartilhada, porque o desejo de viver e a satisfação que leva implícita sua vivência implica uma abertura ao outro e ao desenvolvimento da comunicação, que transcende nos sujeitos que a experimentam. (Cuenca, 2009, p. 63)

A partir desta concepção, deduz-se que a vivência do ócio também possibilita contextos experienciais, que podem ser ambientes para a recriação de

39 Kriekemans, A. (1973). La Educación del empleo de los ocios, en Pedagogía General. Barcelona: Herder. 
novos valores. Cada encontro criativo é uma [re] criação que nos proporciona vontade viver. Segundo López Quintás ${ }^{40}$ (1993 como citado em Cuenca 2009, p. 64), uma experiência compartilhada, de encontro, é uma vivência que proporciona "alegria, entusiasmo, felicidade, liberdade interior, amparo, alegria festiva".

Enquanto dimensão lúdica, o ócio tem sua expressão em múltiplas variantes do jogo, como também em todas aquelas atividades ou práticas que geralmente desenvolvem-se no campo da recreação. No que diz respeito ao jogo, Huizinga (2000) vai buscar destacar algumas das suas principais características:

i. O fato de o jogo ser livre, de ser ele própria liberdade. As pessoas não são obrigadas a jogar, além do que, o jogo perde sua natureza quando deixa de ser diversão para se tornar uma obrigação;

ii. O jogo não é vida corrente nem vida real, pelo contrário, trata-se de uma evasão da vida real para uma esfera temporária de atividade com orientação própria, acompanhado de uma consciência de realidade secundária, ilusória e fictícia;

iii. A terceira das principais características do jogo é $o$ isolamento e a limitação. Joga-se até o final, dentro de certos limites de tempo e de espaço predeterminados;

iv. O jogo, mesmo depois de terminado, permanece como uma criação nova do espírito, algo precioso a ser guardado pela memória, e que pode ser transmitido e repetido em qualquer tempo;

v. O jogo cria ordem e é ordem. Introduz na perturbação da vida e na imperfeição do mundo uma perfeição temporária e limitada, exige uma ordem absoluta, ou seja, a menor desobediência a esta ordem suprema 0 jogo é comprometido, expropriando-o do seu caráter próprio e de todo e qualquer valor;

vi. O jogo é uma atividade de caráter desinteressado, exterior à vida habitual, improdutiva, fora do mecanismo de satisfação imediata das necessidades e dos desejos, desligada de todo e qualquer interesse material: não cria bens, nem riqueza.

40 López Quintás, A. (1993). La cultura y el sentido de la vida. Madrid: PPC. 


\section{CAPÍTULO III}

\section{BUSCANDO UMA APROXIMAÇÃO COM A LINGUAGEM DO CLOWN}

\section{1- O clown: um sucessor da tipologia da máscara cômica}

Buscando estabelecer um ponto de partida, faz-se necessário apresentarmos uma breve abordagem sobre a arte do clown (ou palhaço), que nas últimas décadas ganhou novos contornos e locais, ressurgindo com grande vitalidade nos mais diversos territórios, para o entendimento de uma proposta que utilizou a sua linguagem como um dos elementos centrais na investigação.

Neste estudo, evidencio o termo clown por se tratar de uma nomenclatura mais comumente utilizada no meio teatral, ao contrário de palhaço, cujo termo está mais ligado ao circo, apesar de ter sido no picadeiro circense que este tipo cômico atingiu a sua plenitude e assumiu o seu papel de protagonista. Mas apesar de os termos clown e palhaço possuírem o mesmo significado a etimologia dos vocábulos é completamente distinta. De acordo com Roberto Ruiz (1987 como citado em Burnier 2001, p. 205), "a palavra clown vem de clod, que se liga, etimologicamente, ao termo inglês 'camponês' e ao seu meio rústico, a terra". Já o termo palhaço vem do italiano paglia (palha), que era o material usado para encher colchões, "porque a primitiva roupa deste cômico era feita do mesmo pano dos colchões: um tecido grosso e listrado, e afofada nas partes mais salientes do corpo, fazendo de quem a vestia um verdadeiro 'colchão' ambulante, protegendoo das constantes quedas".

Ao falarmos do clown referimo-nos não apenas a uma tradição ligada ao circo e ao teatro, mas também à manifestação de um tipo cômico que tem suas raízes nas mais antigas civilizações humanas e que traz vestígios de uma profunda relação com a cultura popular. Segundo Viveiros de Castro (2005, p. 11), a figura do "louco" não surgiu em um momento definido, "foi sendo construída ao longo dos séculos e assumindo papéis e formatos diferenciados, tendo como única função, provocar, pelo espanto, o riso". A referida autora aponta que as primeiras referências ao clown surgem na Inglaterra do século XVI, quando os espetáculos de moralidades e mistérios - que focavam temas profanos e 
religiosos com adaptações bíblicas ou alegóricas baseadas na vida dos santos e nos milagres - acrescentam um terceiro personagem: o "rústico". A comicidade desse tipo de espetáculo estava a cargo das figuras do Diabo e do Vice, mas a partir da segunda metade do século XVI a figura do Vice (camponês velhaco, canalha, pecador incorrigível, fanfarrão e covarde) ganha um novo parceiro em cena, o "rústico". Ao longo dos anos o rústico (camponês ingênuo, medroso e supersticioso) vai se desenvolvendo e ganhando características bem definidas, se transformando num tipo extremamente risível.

De acordo com Klaas Kleber ${ }^{41}$ (2012), o clown é herdeiro de toda uma tipologia da máscara do riso da antiguidade, passando pela baixa comédia grega e romana, pelos bufões, pelos bobos da corte da idade média, pelos festejos carnavalescos medievais, pelo teatro popular e religioso da renascença, pela commédia dell'arte e por todos aqueles histriões que buscavam seu espaço de atuação nas feiras e praças, apoiados na arte do improviso, nos jogos e nas situações corriqueiras da vida e do cotidiano. Segundo o referido autor, independente da profusão de nomes que estas figuras assumiam (se bufão, histrião, truão, gracioso, jogral, bobo, grotesco, excêntrico ou saltimbanco) e do tempo e lugar, eram sempre interpretados como loucos, idiotas, divertidos, chocarreiros, toscos e extravagantes. Mais a mais, estas figuras, que eram capazes de provocar gargalhadas ao primeiro olhar, revelam significativas proximidades entre si e até certa indissociabilidade entre a arte e a vida, além de possuírem uma mesma essência: colocar em evidência a estupidez humana; ridicularizar paixões e vícios comportamentais; satirizar valores sociais, morais e saberes institucionais; lançar questionamentos à sociedade vigente.

Detentores de um vocabulário polivalente, de uma linguagem popular, ordinária, hilariante, obscena, obscura, incorreta e de duplo sentido, de caráter bem ao gosto dos temperamentos humanos e das fraquezas morais, estes histriões possuíam uma imensa bagagem de diálogos, como também um arsenal de ações, mímicas, músicas e danças, que era construído a partir das diferentes situações que surgiam no contato com o público. Todas estas manifestações eram pautadas na liberdade, no exagero, no escracho, e suscitavam naqueles que os assistiam o apreço pelo absurdo e pelo caos.

\footnotetext{
${ }^{41}$ Klaas Kleber é o pseudônimo artístico do autor desta tese.
} 
Todos estes cômicos, que encontraram no limiar entre a arte e a vida a sua forma de subsistência, expressão e contestação, também sustentaram por séculos uma prática apoiada em procedimentos técnicos e criativos que davam suporte às suas representações. Seus recursos cênicos, aliados a técnicas de base como a pantomima, a acrobacia, o malabarismo, a mágica, a dança, o canto, entre outras, garantia a teatralidade e o sucesso das suas performances. Estas técnicas, segundo Matos (2009, p. 41), "comumente auxiliavam os artistas a seduzir o público, a provocar o riso e lançar apontamentos críticos-sociais por meio de uma lógica 'às avessas' em contraposição a lógica oficial”.

Descendente direto da tipologia da máscara cômica da antiguidade e proveniente de uma forma de teatro popular, o clown vem reafirmar essa proposição. Sua arte é alimentada e reinventada continuamente pela manifestação dos tipos pertencentes à máscara do riso, o que permitiu uma expansão das possibilidades expressivas do seu fazer artístico. Com herança, a comicidade da performance do clown surge em resposta à exposição do ridículo no ser humano, mostrados por meio do exagero e da contradição. O clown, como os seus antecessores, também coloca à vista um olhar jocoso, relativizado e crítico em relação ao mundo. Conforme Burnier (2001, p. 208), o clown,

\begin{abstract}
Desempenha uma função semelhante à dos bufões e bobos medievais, quando brinca com instituições e valores oficiais. Ele, pelos nomes que ostenta, pelas roupas que veste, pela maquiagem (deformação do rosto), pelos gestos, falas e traços que o caracterizam, sugere a falta de compromisso com qualquer estilo de vida, ideal ou institucional. (...) Seu descomprometimento e aparente ingenuidade lhe dão o poder de zombar de tudo e de todos impunemente.
\end{abstract}

Kasper (2009, p. 206) comenta que o clown é amoral e ao mesmo tempo inocente, "está ligado ao anárquico, ao pequeno, ao minoritário, ao que escapa e foge em uma sociedade". $\mathrm{O}$ trabalho do clown está diretamente ligado às práticas sociais e culturais da sua época, apresenta laços estreitos com a denúncia e a crítica, ou seja, seus mecanismos e sua expressividade revelam-se não apenas como um meio de diversão, mas também como uma forma de questionamento de todo desvio de conduta social e cultural. Através do escárnio o clown manifesta o 
seu repúdio contra padrões, instituições e poderes adversos, muitas vezes repressores, com o intuito de levar o público a repensar valores e normas condicionadas à cultura e à organização social na qual estão inseridas. Como os seus antigos histriões, o clown também busca a elaboração de uma manifestação cênica capaz de humorizar o mundo absurdo e trágico em que ele vive, ultrapassando o espaço da representação e transcendendo sua arte para os territórios da vida.

\subsection{A comicidade e o riso: elementos essenciais da manifestação do clown}

O aspecto cômico é um fenômeno perpetuado na manifestação dos representantes da tipologia da máscara do riso. Segundo Burnier (2001), o princípio desmistificador do riso, presente na cultura popular medieval e renascentista, mostra-se no cômico circense, alicerçado, basicamente, na figura do clown. Como membro dessa tipologia, um dos ingredientes essenciais e componente da performance do clown é a sua capacidade natural ou adquirida de estimular o riso na plateia. Mas como um ser tão vulnerável em sua humanidade pode provocar o riso nas suas mais sutis gradações?

Por mais trágica que seja a atuação do clown, ele é um ser impulsionado pelo prazer de fazer as coisas, pelo prazer de brincar, pelo prazer de galhofar, pelo prazer de estar ali, junto da plateia, promovendo a alegria e o riso. Deste modo, podemos entender a performance do clown como um convite para uma "cerimônia do divertimento e do riso". Os efeitos cômicos promovidos pelo clown normalmente compreendem aspectos relacionados à leveza, à ingenuidade, à fragilidade, à vulnerabilidade, à inadequação pela vida da pureza e o reconhecimento do risível de si mesmo. O clown, conforme Viveiros de Castro (2005, p. 11), é facilmente identificado "pela sua capacidade de nos colocar, como espectadores, num estado de suspensão e tensão que, em segundos - sabemos de antemão - vai explodir em risos". Sua comicidade atrai facilmente o espírito cômico do espectador, que já se mostra influenciado pelo simples entendimento de saber que está à frente de um "sacerdote da besteira", das inutilidades, da bobeira. Basta um simples tropeção ao entrar em cena e o clown, devido ao seu desajeitamento, já garante sonoras gargalhadas da plateia, pressupondo uma 
relação de cumplicidade. A referida autora aponta que o clown "é um ser estranho que bota a mão no fogo, que põe a cabeça na guilhotina e que se expõe nu em sua tolice e estupidez. Ele não conta uma história engraçada. Ele é a graça, ele é o risível" (de Castro, 2005, p. 257). Sua reação aos pontapés ${ }^{42}$, por exemplo, terminam por provocar verdadeiros trambolhões, definindo situações e provocando o riso na plateia. Segundo a mesma autora, "um tapa bem dado e bem levado, um tombo de cara no chão ou que se transforma numa cambalhota são gestos que já fizeram rir nossos antepassados e farão nossos netos e bisnetos gargalharem para todo o sempre" (de Castro, 2005, p. 77). A comicidade física do clown está fundamentada na destreza, na audácia e na exatidão com a qual ele responde aos acontecimentos fortuitos e inusitados. O seu repertório de gags $^{43}$ físicas, aliado ao travestimento, ao jogo lúdico e espontâneo com a plateia, aos artifícios visuais e ao arsenal de práticas como a pantomima, a acrobacia, o malabarismo, a mágica, a música e a dança, são alguns dos efeitos, entre outros, que dão suporte e ajudam o clown na produção de resultados hilariantes.

A comicidade do clown baseia-se também no "jogo de palavras", sobretudo, no desleixo da sua linguagem, que corresponde, ponto-a-ponto, à comicidade das suas ações e atitudes, "permitindo assim a comicidade passar por uma gama infindável de graus, desde o burlesco mais vulgar até as elevadas formas do humor e da ironia" (Bergson, 1983, p. 59). Munido de uma linguagem popular e ordinária, obscena e incorreta, de duplo sentido ou de sentido inverso, e de caráter bem ao gosto dos temperamentos humanos e das fraquezas morais, 0 clown incita a graça no espectador ao mesmo tempo em que revela a sua tolice ou, às avessas, sua inteligência e astúcia.

Mesclando aspectos como humanidade e animalidade, a comicidade do clown também utiliza de uma expressividade grotesca, que é um elemento fundamental para exibir o que a existência tem de inadmissível e provocar um riso irônico e incrédulo. $O$ traço grotesco na manifestação do clown degrada o que é sublime e traz para o baixo corporal tudo aquilo que se impõe por uma elevação, ou seja, transfere o que se mostra elevado e espiritual para uma perspectiva

\footnotetext{
${ }^{42}$ Dar e levar um pé na bunda é uma arte cultivada ao longo de gerações. Exige ritmo, equilíbrio, reflexos rápidos e senso de oportunidade, além de ser uma bela metáfora de situações de humilhação e rejeição pelas quais todo ser humano passa na vida, mas que gostaríamos de manter em segredo e de esquecer para sempre (Viveiros de Castro, 2005, p. 77).

43 Uma "gag" é qualquer efeito cômico, geralmente muito breve, inserido numa representação.
} 
material e corporal, apresentando aspectos sublimes em sua representação. $O$ clown consegue alternar harmoniosamente o sublime e o grotesco, exaltar a beleza ao lado do ridículo, revelando, deste modo, a presença de elementos paradoxais, numa combinação bem-sucedida. $O$ traço grotesco na manifestação do clown também está ligado ao tragicômico: "o equilíbrio instável da conciliação entre o trágico e o risível” (Matos, 2009, p. 41). Segundo Shklovski ${ }^{44}$ (1975 como citado em Burnier 2001, p.206), o clown é "a encarnação do trágico na vida cotidiana; é o homem assumindo sua humanidade e sua fraqueza, e, por isso, tornando-se cômico". O trágico é visto aqui como uma ação libertadora, cuja manifestação é capaz de provocar no público uma perspectiva inquietante em relação a uma determinada situação, que deforma, com traços divertidos, os elementos morais da vida em sociedade, suscitando um movimento de satisfação da própria condição humana - o riso.

A graça suscitada no espectador também é resultado da sua identificação com a figura excêntrica e grotesca do clown, cujas atitudes apontam para o reconhecimento de gestos sociais que rompem com a "conduta ideal" e com o "senso comum", relacionados com a realidade e conhecimento da plateia. Seus mecanismos geradores do riso revelam-se não apenas como um meio de diversão, mas também de denúncia e crítica de todo desvio de conduta social, a partir de um olhar contrastante, quando não contraditório, em relação às normativas vigentes. De modo transgressor os gestos do clown desfazem toda a verdade preexistente e toda ideia absoluta de bem e de mal, rompendo com "a cortina de uma realidade rígida, coerente e plasticamente perfeita, evidenciando sua fragilidade e escancarando o ridículo daquilo que pretende se impor" (Tavares, 2008, p. 37), colocando o espectador em contato com a perplexidade, diante do absurdo dos seus valores e normas condicionados à cultura à qual ele pertence. A comicidade do clown é um elemento fundamental para mostrar o que a existência humana tem de mais inaceitável e risível, pressupondo a suspensão de um julgamento moral, o que não significa imoralidade, mas sim, como aponta Kundera $^{45}$ (1994 como citado em Tavares 2008, p. 36), uma "moral que se opõe à irremovível pratica humana de julgar imediatamente, sem parar, a todos, de julgar antecipadamente sem compreender".

${ }^{44}$ Shklovski, V. (1975). El clown, la comedia y la tragedia, in El circo soviético. Moscou: Progresso.
45 Kundera, M. (1994). Os testamentos traidos: ensaios. Rio de Janeiro: Nova Fronteira. 
O riso também é resultado do sentimento de superioridade que o espectador expressa em relação àquelas situações às quais o clown não consegue se adaptar. Contudo, segundo Matos (2009, p. 59), "tais situações se revertem, quando se transformam num espelho capaz de refletir no espectador a sua própria imagem", levando-o a entrar em contato com aspectos de si, a reconhecer a sua própria imperfeição, estupidez e vulnerabilidade, a identificar na comicidade do clown a incidência do humano em condições semelhantes à sua. Neste sentido, o riso pode ser percebido como uma forma de autocompreensão, como algo que possibilita ao ser humano compreender-se, afinal, rir do outro é rir também de si próprio. Como aponta Viveiros de Castro (2005, p. 205), "rimos como se fôssemos dois, um que age e outro que, ao ver a estupidez e as bobagens deste um, que é ele mesmo, ri".

No seu "Ensaio sobre a significação do cômico" Bergson (1983, p. 2) afirma que "não há comicidade fora do que é propriamente humano". Segundo o autor, rir e fazer rir são características que definem o homem. Se rimos de um animal ou de um objeto qualquer é pela sua semelhança com o homem, ou seja, um animal só nos causa riso quando revela uma atitude ou certa expressão humana, como um objeto só nos é risível quando assume uma forma ou molde da fantasia humana. $O$ cômico é algo que se destina à inteligência pura e que para produzir efeito, que é o riso, exige uma certa insensibilidade que naturalmente acompanha o riso ou uma suspensão momentânea da emoção, haja vista que esta é a maior inimiga do riso.

Já o riso, é algo que está relacionado ao indizível, ao impensado e ao desprendimento dos limites da razão. Mediante Bergson (1983), o riso tem uma significação social, além de corresponder a certas exigências da vida em comum. O riso é um fenômeno que atravessa todos os segmentos sociais e que se mostra, com certeza, ligado ao espaço de experiência vivenciado por cada indivíduo, como também na leitura que este mesmo indivíduo faz de si mesmo e do meio social o qual está inserido, revelando uma visão de mundo, de épocas e de grupos distintos. Com tudo isto, os limites do cômico e do riso se mostram sempre instáveis, ou seja, o que é aceitável para uma determinada cultura pode não o ser para outra, bem como os motivos dos quais se ri. No mais, além de um gesto social, o riso é também um dispositivo usualmente capacitado para atuar 
como dissipador do medo ${ }^{46}$. O riso, pelo temor que inspira, "reprime as excentricidades, mantém constantemente despertas e em contato mútuo certas atividades de ordem acessória que correriam o risco de isolar-se e adormecer; suaviza enfim, tudo o que puder restar de rigidez mecânica na superfície do corpo social" (Bergson, 1983, p. 14).

Independente se na arte ou na vida, o riso é um fenômeno capaz de aliviar as tensões do dia-a-dia, de elevar as forças vitais e potencializar a vida. Normalmente rimos de figuras excêntricas, de comportamentos inusitados, de imitações grotescas, de chacotas sobre acontecimentos correntes, de histórias engraçadas, de piadas, de caretas. Rimos também de nós mesmos, da nossa seriedade, da nossa confiança em nossas certezas, da nossa mediocridade imaginativa. Rimos quando nos divertimos: dançando, cantando, brincando, jogando. Rimos em qualquer lugar, seja numa festa, num velório, num batizado, num restaurante. Alguns riem de tristeza, de medo, de ódio, de desespero, outros riem da fome, da miséria, da fraqueza, do sofrimento e da morte. O riso alimenta o ser humano para que este possa de algum modo descomprimir-se dos dramas da vida. O riso é uma forma vital de curar-se de tantos dramas cotidianos e compreender-se.

Durante milênios e até nos dias de hoje valorizamos a sabedoria e a capacidade para vencer, seja lá o que isso signifique. Por isso, a apologia do trabalho, da moderação, do equilíbrio. Grandes valores, sem dúvida, mas a vida não é só isso: existe a farra, a festa, o prazer! E assim o homem vai vivendo, equilibrando-se entre os contrários, compreendendo a necessidade de "ganhar o pão com o suor do seu rosto", mas criando mecanismos para escapar das pressões cotidianas, reagir aos exageros dos puritanos e se contrapor à tristeza e à violência do mundo (de Castro, 2005, p.15).

46 De acordo com Nunes (2010, p. 7), na idade média, por exemplo, o riso representava uma vitória sobre o medo, "não apenas o temor místico e natural, mas igualmente o medo moral, que oprimia e dominava a consciência, o medo que ultrapassava os aspectos sagrados e inseria-se no mundo profano, o medo do poder divino e também humano, dos mandamentos e leis, da morte, do inferno e de tudo o mais que permeava o imaginário da época, libertando o homem não apenas das censuras exteriores, mas também do grande censor interior". 


\title{
3.3 O clown: uma caricatura pessoal, única e intransferível
}

Num primeiro olhar poderíamos pensar que o clown é um personagem e, como tal, construído por um ator que o representa como uma figura dramática separada de si mesmo. De acordo com Luís Otávio Burnier (2001), um clown não se representa, ele é, não se trata de uma personagem ou de uma caricatura separada daquele que o desempenha, mas da exposição desmedida dos aspectos ingênuos, puros e humanos do ator, dos seus sentimentos, das suas fraquezas, das suas características pessoais, do seu lado estúpido, ridículo e patético de ser, tão bem camuflado. De acordo com Lecoq (1997 como citado em Kasper 2009, p. 203) "o clown não existe fora do ator que o representa".

\begin{abstract}
A busca do seu próprio clown é, em primeiro lugar, a busca de sua própria insignificância. Diferentemente da Commédia dell'Arte, o ator não entra em um personagem pré-estabelecido, mas descobre em si as partes clownescas que o habitam. Quanto menos se defende, menos tenta representar um personagem, mais o clown aparece forte.
\end{abstract}

O clown é desenvolvido a partir do perfil individual daquele que o desempenha, portanto, ele é pessoal, único e intransferível, não tem uma forma fixa e definida, não podemos enquadrá-lo. O termo "pessoal" evoca no ator o exercício da exposição da sua singularidade para a construção do seu clown: refere-se à criação de uma lógica própria, de maneiras próprias de agir, pensar e sentir; refere-se à busca da compreensão do seu modo pessoal e específico de jogo e de relação, da produção de si, do [re] inventar-se; refere-se aos modos de existência ligados àquele que o cria.

Segundo Kleber (2012), construir um clown implica em estabelecer um confronto entre a máscara estereotipada que esconde a pessoa do ator e a essência do seu próprio ser. É necessário que o ator embarque numa busca dolorosa de si mesmo, num processo inquietante de "desconstrução", que tem como ponto de partida a sua própria subjetividade. Nesta busca, o ator é levado a expor suas imperfeições, a aceitar o seu fracasso, a reconhecer o seu ritmo próprio de ação, sua comicidade pessoal e a permitir-se a todos os riscos. Todo 
este processo vai compreender um estado de abertura, de generosidade e de vulnerabilidade, extremamente necessários para se atingir a espontaneidade, a fragilidade, a ingenuidade, a pureza e a alegria de um clown.

Segundo Dario Fó47 (1998 como citado em Dorneles 2003, p. 53), "é preciso convencer-se que alguém só se torna clown em consequência de um grande trabalho, constante, disciplinado e exaustivo, além da prática alcançada somente depois de muitos anos. Um clown não se improvisa". Cada clown traz em si características que lhe confere uma forma de expressão muito particular e que revelam a sua personalidade. Quanto mais personalidade tiver o clown, mais estilo ele terá. Constituído, então, de uma personalidade própria o clown pode representar 'todos os 'personagens sociais' que quiser e/ou precisar, pois veste, acima de tudo, não um tipo específico e rígido, mas o estereótipo da troça, de si mesmo e de todos ao mesmo tempo" (Federice, 2005, p. 125).

Historicamente são considerados dois tipos clássicos de clowns: o Branco e o Augusto. Burnier (2001) comenta que uma pessoa pode ter inclinação para um ou outro, dependendo da sua personalidade. O primeiro clown, o $\mathrm{Branco}^{48}$, é a representação do patrão, o cerebral, o intelectual, o prepotente, o mandão, que está sempre pronto a enganar o seu parceiro em cena, o Augusto. Já este último, é a encarnação do bobo, o tolo, o emocional, o perdedor, o ingênuo, ao mesmo tempo astuto, e que está sempre sujeito ao domínio do Branco. Segundo o referido autor, quando os dois clowns atuam juntos, servindo de contraponto um ao outro, as relações e os jogos criados entre eles se tornam mais ricos, contribuindo ainda mais para a comicidade das cenas. Esta tática de contraponto permite ao tolo superar o intelectual ou, por assim dizer, ao mais fraco se sobrepor ao mais forte, fazendo triunfar a pureza sobre a malícia e o bem sobre o mal.

O contraponto entre os clowns Branco e Augusto, conforme Kleber (2012), é um aperfeiçoamento da relação existente entre os servos (Zannis) da commédia dell'Arte italiana, cujos cômicos eram movidos pelo seu instinto de sobrevivência, por uma insaciável fome e pelas necessidades mais elementares do ser humano, como o alimento, o descanso e a procriação. Suas cenas cômicas eram

47 Fo, D. (1998). Manual Mínimo do Ator. São Paulo: SENAC.

48 Tradicionalmente, tem rosto branco, vestimenta de lantejoulas (herdada do Arlequim da commédia dell'arte), chapéu cônico e está sempre pronto a ludibriar seu parceiro em cena (Burnier, 2001, p. 206). 
desenvolvidas, principalmente, a partir das trapaças e trejeitos com que cada um deles buscava satisfazer o seu insaciável apetite. O primeiro zanni, Brighella, enganava com astúcia, blasfemava e gozava o patrão, provocando o riso pela sua engenhosidade e pelas suas intrigas. Já o segundo zanni, Arlecchino, era estúpido e ingênuo. Frequentemente as tramas da commédia dell'Arte traziam à cena uma dupla de criados e a eles atribuía o trabalho de realizar o maior número de cenas cômicas, por suas atitudes contrastantes, estabelecendo um confronto entre o primeiro e o segundo servo, isto é, entre o trapaceiro e o estúpido, o carrasco e a vítima, o astuto e o tolo, o engenhoso e o insensato.

\subsection{O nariz vermelho: primeiro elemento de composição do clown}

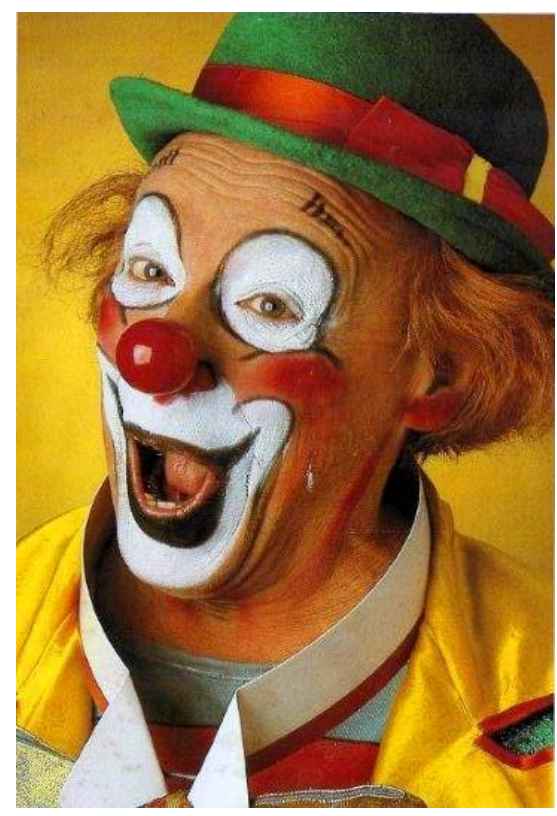

Imagem 02: Palhaço Torresmo

(Brasil José Carlos Queirolo - 1918/1996)

O estudo dos caracteres morfológicos da máscara cômica popular é composto por certos códigos que nos levam a identificar, num primeiro olhar, os seus representantes, haja vista que estes códigos trazem em si a personificação de um determinado tipo ou personagem. A máscara do clown, o nariz vermelho, primeiro elemento de composição deste tipo cômico, seria uma dessas variantes. O nariz do clown é uma representação simbólica, um signo de identificação, um 
sinal indicativo, capaz de revelar ao público que estes estão à frente de um "sacerdote da besteira". Da mesma forma que o nariz vermelho, a vestimenta, a maquiagem, os acessórios e as deformações físicas (barriga exagerada, grandes glúteos e pés escomunais) também são elementos importantes na composição de um clown, constituindo um disfarce para o risível. O clown sempre busca uma caracterização capaz de contrastar com a lógica da razão e com os padrões sociais. Contudo, não importa se um clown usa cabeleira, sapatos grandes ou se, ao contrário, traja um terno sóbrio e não usa maquiagem, identificamos um clown não apenas pela sua aparência ou forma, "mas principalmente pela sua capacidade de nos colocar, como espectadores, num estado de suspensão e tensão que, em segundos - sabemos de antemão - vai explodir em risos" (de Castro, 2005, p. 11).

De acordo com Burnier (2001, p. 218), a máscara do clown, o nariz vermelho, "é a menor máscara do mundo, a que menos esconde e mais revela". Enquanto dispositivo, o nariz vermelho concede ao ator uma atitude de liberdade e um estado de presença no seu estado mais puro, voltado para o prazer de brincar e de estar em cena, além da percepção de um outro modo de ser, estar e interagir com o mundo. O nariz vermelho é utilizado na composição de uma lógica própria de ação/reação, que surge do confronto entre o universo interior do ator e os estímulos vindos de fora. Usar a máscara do clown é buscar um diálogo entre a "voz de si" e a "voz do mundo", uma vez que ela obriga o ator a "colocar-se em situação de risco e buscar um diálogo lúdico consigo mesmo, com o outro, e com o espectador, num espaço-tempo mutante" (Costa, 2005, p. 36). Esta forma particular de estar no mundo, aos poucos, é que determinará a lógica própria do clown, como também a sua personalidade. Todo este processo vai compreender os aspectos relacionados à leveza, à ingenuidade, à fragilidade, à vulnerabilidade, à inadequação pela vida da pureza e o reconhecimento do risível da pessoa do próprio ator. Vestir a máscara do clown, o nariz vermelho, é ocultar-se e, ao mesmo tempo, se expor.

Não podemos pensar a máscara do clown somente como um acessório ilustrativo ou simbólico, se usada com consciência ela pode se tornar, mais do que um elemento estético, técnico ou ideológico, um dos principais dispositivos para se atingir o que muitos estudiosos denominam de "estado de clown". Mediante Costa (2005), toda máscara cênica exige um estado de presença 
correspondente tanto à energia elaborada pelo ator quanto à energia concentrada nela mesma. Segundo a autora, "quando se fala em energia há, pelo menos, duas possibilidades: a que se refere ao trabalho do ator e à concentrada no objeto, configurada pela forma, pelas linhas e pelo material do qual ele é feito" (Costa, 2005, p. 41). A máscara provoca naquele que a utiliza um estado que se assenta sob uma determinada energia e que implica uma confluência psicofísica mediada pelo objeto. Manter este estado ou esta "segunda natureza" requer, por parte do ator, o exercício do corpo/mente.

Energia e estado na máscara podem ser compreendidos sob múltiplos aspectos, e estes se manifestam mediante 0 ator e 0 objeto postos em relação. Não há um receituário que permita alcançar e manter determinado estado; tampouco há uma medida temporal para que isso aconteça, cada ator elabora o seu próprio percurso, partindo de princípios que são comuns a todos. (Costa, 2005, p. 44)

A máscara redimensiona os sentidos do ator, além de instrumentalizá-lo no processo de redescoberta do seu próprio corpo e de si mesmo, demarcando uma fisicalidade que implica a evidência e imediaticidade de uma reação física diante de qualquer fenômeno que surja. É importante que o ator perceba as mudanças físicas que a máscara implica e traz. "Essas mudanças transformam, por sua vez, os hábitos de percepção, permitindo ao ator experimentar outro modo de estar no mundo, percebê-lo e interagir com ele" (Machado, 2005, p. 10). Além disso, a máscara do clown faz com que os movimentos do ator sejam consideravelmente dilatados, exacerbados, da mesma forma como ele exagera na representação dos sentimentos humanos, das paixões e dos vícios da humanidade.

\subsection{Procedimentos e técnicas utilizadas na criação e performance do clown}

Construir um clown envolve processos diversos, atravessados por procedimentos e técnicas específicas de relação com a alteridade. Uma das técnicas mais recorrentes num processo de criação do clown é a da improvisação. 
Mediante Costa (2005, p. 39), "improvisar é da natureza da máscara, dado que o objeto deve, a cada dia, ser animado, receber o sopro divino - respiração - pelo ator, para colocá-la e se colocar em movimento". Sem pretender um resultado estético, a técnica da improvisação é percebida como um poderoso instrumento onde se conjugam diversos princípios da atuação. É um meio de afinação do corpo/mente do ator, que está em constante aprendizagem e aperfeiçoamento, fazendo desta prática um elemento contínuo no seu treinamento, haja vista que esta técnica o qualifica no que diz respeito à percepção, à ação e ao jogo, além de torná-lo apto a distinguir os objetivos, o foco e as necessidades do momento.

Seja como recurso de criação ou como um modo de ação na representação, a improvisação "ancora-se em princípios que atuam como propulsores para o imponderável, o fenômeno imprevisto (que pode ser pré-visto) e, no calor do evento, assume uma natureza inaugural" (Costa, 2005, p. 39). Enquanto forma de expressão espontânea, momentânea, informal e desprovida de forma, a improvisação revela em si o imprevisível, o inesperado, causando sempre no espectador uma sensação de frescor. Tal habilidade, desenvolvida pelo ator, reflete no comportamento do clown, que é caracterizado pela ação natural e pela ação/reação com o meio, que acontece de forma livre, espontânea e rápida. $O$ ato de improvisar desenvolve no clown o sentido de atenção, presença e cumplicidade, para responder às eventuais manifestações que sucedem em determinados momentos. Segundo kasper (2009, p. 207), "o ator, para construir o clown, precisa produzir uma inteligência corporal capaz de, ao mesmo tempo, agir de modo extremamente rápido e muito lentamente, conforme a situação". O clown, que é um improvisador, manifesta essa interação através do seu modo de estar e de se relacionar com o seu entorno, seja ele o espaço físico, o cenário, o figurino, os objetos cênicos, a música, a iluminação, o público, os companheiros de cena, os jogos estabelecidos e as situações dramáticas, numa atitude de abertura e de conectividade.

A criação de um repertório é outro procedimento importante utilizado pelo clown. Geralmente ele se serve de um repertório simples, com indicações básicas e sugestões esquemáticas de jogos, de pontos de referência, sem falas decoradas e sem marcações rígidas. Este repertório, por mais estruturado que estivesse, está constantemente sofrendo modificações, ainda que sutis. Nele o ator encontra total liberdade de atuação, adaptação e criação. Consoante Costa 
(2005, p. 39), "embora vá construindo um repertório, o ator não Ihe tem apego e, a cada vez que há o encontro entre ator e máscara, a (re) conhece, a (re) vê, a (re) cria". Esta é a razão pela qual os "números" de um clown são habitualmente transformados ao longo do seu percurso artístico.

Segundo Matos (2009, p. 56), o repertório de um clown é "frequentemente organizado de forma a conferir flexibilidade ao artista em seu diálogo com a plateia", que é um outro elemento importante para a sua construção. O contato imediato com a plateia rompe com o continuum dramático, agregando à performance do clown os incidentes presentes no meio, em especial aqueles advindos dela. A manifestação do clown é sustentada a partir desta relação, uma vez que a sua atuação se valida no jogo com a plateia, já que ela estimula o clown em jogo, colocando-o numa dinâmica de ação/reação, num jogo de perguntas e respostas. $\mathrm{O}$ agir/reagir em conformidade com a plateia permite ao clown alargar a sua capacidade de expressão e ultrapassar os limites do seu próprio ser, além de contribuir na construção de um gestual estético e ideológico que Ihe empresta forma e movimento. Segundo Ricardo Puccetti (2009, p. 123),

(...) interagir com cada indivíduo do público é parte fundamental da técnica do palhaço. Por isso a importância do olhar, pois é através de seus olhos em contato com os olhos de cada pessoa da plateia, que o palhaço pode ir "pescando" um a um na construção de sua relação com o público.

O repertório vocal de um clown também caracteriza este tipo cômico. Quanto mais polivalente for o seu vocabulário, quanto mais ordinária for a sua linguagem (obscena e de duplo sentido), de caráter bem ao gosto dos temperamentos humanos e das fraquezas morais, mais risível ele será. $E$ isto em decorrência da proximidade ou possível identificação da plateia com o seu modo de expressar. Normalmente o clown também explora falhas e diferenças que marcam a sua dicção, como por exemplo, perturbações na fala, gagueira, sotaque, além de termos e expressões que caracterizam sua intelectualidade ou tolice. O timbre, o ritmo, o tom, a musicalidade, entre outros elementos relativos à voz e à linguagem, também é bastante explorada no trabalho de criação do clown. 
A performance do clown também se serve de um arsenal criativo constituído de práticas como a pantomima, a acrobacia, o malabarismo, a mágica, a música e a dança, entre outras. Práticas estas, que dão suporte e ajudam o clown a incitar o riso por meio de uma lógica "às avessas", contrapondo a lógica oficial. Estas práticas conferem ao clown um acervo técnico e criativo repleto de teatralidade, além de servir de alternativas de repertório, enriquecendo ainda mais os seus jogos de cena em qualquer situação de representação. Algumas destas habilidades envolvem força, resistência, velocidade, destreza, amplitude muscular, rapidez de reação e precisão motora.

A construção do clown parte também do corpo do ator. De um corpo entendido como algo que ultrapassa o corpo biológico e a forma desenhada pelo figurino e pela maquiagem; de um corpo gerado a partir da produção de outras lógicas, de outros modos de sentir, agir e pensar; de um corpo produzido a partir da experimentação, exposto e disponível para o jogo; de um corpo preparado para viver e atuar no tempo presente, cujo estado de percepção, prontidão e comunicabilidade integra $\mathrm{o}$ clown aos acontecimentos imediatos $\mathrm{e}$ às necessidades do momento. De acordo com Kleber (2012), num treinamento voltado para a elaboração do clown buscamos a desconstrução do corpo cotidiano do ator, entendido como um corpo automatizado, e a construção de um "corpo cênico", um "corpo teatral", como estratégia fundamental para se atingir certa eficácia comunicativa. Segundo Kasper (2009, p. 206), "para fazer um clown é preciso fazer um corpo. Não se trata de um corpo dado, mas um corpo produzido nas diversas experimentações que constituem o processo de construção de um clown". Este treinamento é que vai permitir ao ator uma primeira vivência da utilização cômica do corpo, que é particular para cada um, trabalhando justamente as suas vulnerabilidades.

\subsection{O estado de inter-relação: uma ressonância entre corpos}

As dinâmicas criativas do ator geralmente são agenciadas pelas interrelações que permitem a ele [re] inventar e [re] significar suas possibilidades de criação, levando-o a "expandir-se para além de seus próprios limites, erguendo fendas de luz capazes de criar outros territórios de expressão e de vida" (Matos, 
2009, p. 52). Estes encontros/confrontos é que estimulam o ator em jogo, permitindo-o alargar a sua capacidade de expressão, estender o seu repertório técnico e ultrapassar os limites do seu próprio ser, além da construção de um gestual estético e ideológico que lhe emprestará forma e movimento. Na prática do clown esses encontros/confrontos ocorrem a partir da relação que 0 ator estabelece com o seu entorno, com o mundo à sua volta, seja ele o espaço físico, o cenário, o figurino, os objetos cênicos, a música, a iluminação, o público, os companheiros de cena, os jogos estabelecidos e as situações dramáticas. Como aponta Kasper (2009, p. 207), "uma criação que envolve a ressonância entre corpos, e não apenas um ator voltado para si mesmo". Esta interrelação entre o clown e as singularidades e diferenças percebidas no ato da representação permite ao ator [re] criar o seu repertório e articular o seu arsenal criativo a cada representação.

O que fascina o público quando vê um palhaço atuando, é sua "inteireza", o prazer com que executa seu número e sua capacidade de estar presente e vivo em cada microssegundo de sua passagem pelo palco. Se o palhaço possui essa "inteireza" e prazer de existir, ele vai emocionar e surpreender a plateia, provocá-la e conduzi-la do sorriso à gargalhada. E cada pessoa do público sairá com a sensação de ter feito parte do espetáculo (Puccetti, 2009, p. 123).

Conforme Machado (2005, p. 13), "o clown e o ambiente em que ele está dispõem-se mutuamente a um jogo de receber, trocar e devolver estímulos. Receber, trocar e devolver comicamente os estímulos do ambiente e do clown". Esta relação possibilita ao clown transformar o seu espaço de atuação e criar novos sentidos e significados, a partir das relações ali existentes. O clown "é um conjunto de impulsos vivos e pulsantes, prontos a se transformarem em ação no espaço e no tempo" (Puccetti, 2009, p. 122). Estes impulsos se manifestam a partir da sua lógica, como também da sua interação com a plateia.

De acordo com Ferracini (2003), o raciocínio do clown é inteiramente corpóreo, suas ações e reações são todas corporificadas, ele não só sente com o corpo, mas também pensa e dialoga através dele, suas palavras estão em seu corpo, em seu dinamismo, em sua musculatura, bem estabelecidas, claras, 
conhecidas, num estado particular de comunicação e interação com o mundo. Burnier (2001, p. 219) comenta que,

É o modo de ser e pensar do clown que determina todas as suas ações e reações, sua dinâmica, seu ritmo. Não se trata de um pensar puramente racional, mas de um pensar corpóreo, muscular, físico. É o corpo que age e reage segundo a lógica do clown. É um pensar afetivo e emotivo. Mas, sobretudo, o aspecto corpóreo desta afetividade e emocionalidade.

Segundo o referido autor, esse modo de "pensar corpóreo" (afetivo e emotivo) é o que caracteriza a lógica do clown ${ }^{49}$. Sua energia e sua emoção extravazam pelos poros, "e essas energias/emoções devem estar latentes no corpo do ator. Ele deve buscá-las e transformá-las em corpo" (Ferracini, 2003, p. 217). Machado (2005, p. 36) comenta que "as emoções e os sentimentos são as primeiras sinalizações passíveis de serem conhecidas pelo corpo que as produziu e constituem estados que orientam a ação do organismo no meio". O modo de agir emotivo proporciona ao clown uma alteração na sua percepção sensitiva, expandindo o seu estado de consciência, tornando-o apto a produzir imagens, relações, memórias, sensações e pensamentos, que se organizam para ajustar uma resposta adequada às outras tantas informações desencadeadas.

\subsection{O "estado de clown": uma segunda natureza do ator}

De acordo com Kleber (2012), o que um ator experimenta ao atingir o estado de clown é o emergir de outras possibilidades de ser, estar, existir e fazer, antes não acessadas, e a sensação de que tudo lhe é permitido. Mas o que seria o estado de clown? Segundo o referido autor, alguns autores interpretam este estado como sendo o "guia interior", o "fluxo de vida" ou a "energia condutora", que dá suporte, substancializa, preenche, e justifica a atuação do clown, e que

49 De acordo com Kleber (2012), a lógica do clown é que vai determinar a forma como ele deve agir ou reagir, enfatizar ou inverter os sentidos e significados da realidade, transformando-a no que desejar, contestando os acontecimentos até então estabelecidos. 
tem como pilares a liberdade, a espontaneidade, a brincadeira, o jogo, a criação e a alegria. Contudo, encontrar uma definição única e completa para o "estado de clown" se torna uma tarefa bastante complexa.

O estado de clown, mediante Costa (2005, p. 43), "é um constante fluir que envolve sentimento, emoção, pensamento e articula-se com a ação". Na prática teatral este estado "relaciona-se à alteração da consciência psicofísica do ator, e traz no seu bojo a energia necessária para a construção de um corpo cênico" (Costa, 2005, p. 45). Já Puccetti (2009, p. 71), percebe o estado de clown como sendo "um estado de afetividade, no sentido de 'ser afetado', tocado, vulnerável ao momento e às diferentes situações". Segundo o referido autor, para se atingir este estado é necessário que o ator leve ao extremo a conexão consigo mesmo e o outro, aprenda a ouvir a si próprio e a plateia, livre-se dos estereótipos e das armaduras.

Kleber (2012) aponta que uma das estratégias usadas pelo pesquisador Ricardo Puccetti para levar um ator a atingir o estado de clown é a situação do picadeiro ${ }^{50}$. No picadeiro o ator experiencia o "sentir-se exposto", o "ser visto", o "revelar algo íntimo" para a plateia. Para Puccetti, é na situação do picadeiro, jogando com a plateia, que o clown começa a recolher materiais (formas de caminhar, de gesticular, de olhar, de manusear objetos, etc.), como também a criar e construir o seu comportamento físico e a sua lógica natural ou própria. A situação do picadeiro leva 0 ator a experimentar outro modo de estar e de interagir com o mundo, a desenvolver a sua potencialidade expressiva e perceptiva, sua capacidade de pergunta e resposta, suas habilidades de jogo e improvisação. Puccetti (2009, p. 123) aponta que "o 'picadeiro' coloca o aprendiz em situação de desconforto, o que leva a um 'desmoronamento' de suas defesas naturais, aqueles estereótipos ou fórmulas já prontas, às quais sempre nos apegamos nos momentos de aperto".

Para a pedagoga Ângela de Castro, segundo Matos (2009), o estado de clown corresponde a uma força interior capaz de garantir ao ator um suporte psicofísico. Conforme a referida autora, Ângela de Castro criou um sistema constituído por mandamentos que "funcionam como pilares que permitem ao

50 Picadeiro é o termo utilizado para designar a parte central e circular do circo, onde se fazem as exibições. Aqui, podemos perceber "picadeiro" como sendo qualquer área de cena em formato de arena. 
artista mostrar-se de forma vulnerável e permeável ao outro, tendo como sustento o seu estado de palhaço: um estado de liberdade e de imaginação, um território para expor e brincar com sua própria imperfeição" (Matos, 2009, p. 110). Estes mandamentos referenciam as circunstâncias vivenciadas $e$ as atitudes experimentadas psicofisicamente pelo ator durante o seu treinamento prático. Nestre treinamento, segundo a pedagoga, o complicado não é ativar o estado de palhaço, mas sustentá-lo durante um treinamento intenso e disciplinado.

O primeiro mandamento é o prazer de estar em cena. Este mandamento dá sustentação à imagem carismática do clown, além de conferir ao ator o envolvimento, a prontidão, a presença, o estar no momento, no aqui e agora. A simplicidade é outro fundamento desenvolvido pela pedagoga. Segundo ela, não é necessário o ator fazer muita coisa em cena, ele deve manter uma calma interior, interagir sem pressa, observar, a fim de perceber os momentos exatos de agir e reagir. Os outros mandamentos também compartilham da mesma importância destes mencionados, e são eles: inocência, curiosidade, coragem, esperança, comprometimento, cumplicidade, disciplina. E ainda: amor, felicidade, alegria, verdade, entrega, aceitação, brincadeira, risco, fé, confiança, serenidade, estar no momento (Matos, 2009). 
PARTE 2

FUNDAMENTAÇÃO E PERCURSO METODOLÓGICO 


\section{CAPÍTULO IV}

\section{O PROJETO INVESTIGATIVO}

\section{1- Questões de estudo}

$\mathrm{Na}$ contemporaneidade, com o alcance da longevidade da população e o expressivo envelhecimento populacional global, a velhice passou a ser vista como mais uma etapa do desenvolvimento humano e interpretada como um acontecimento positivo para toda as sociedades, a partir do momento em que a possibilidade de envelhecer bem, com saúde e com qualidade de vida se tornou uma realidade para os próprios indivíduos, representando uma conquista para a humanidade. É visível a mudança de uma abordagem historicamente centrada nos aspectos genético-biológicos para uma perspectiva que reconhece a velhice como um setor socialmente importante e em crescimento, como também a tendência de revisão dos estereótipos associados a ela, que busca relacionar essa etapa da vida, a da velhice, à atividade, à aprendizagem, à produtividade, à participação, às novas conquistas, à independência, à autonomia, aos vínculos amorosos, à possibilidade de uma vida longa, saudável e com experiências positivas, satisfatórias e enriquecedoras. Se envelhecer, até então, era sinônimo de decadência física e invalidez, onde imperavam a inatividade, a solidão e o isolamento afetivo, hoje a velhice passou a significar o momento propício para a busca de lazer, para a busca de conhecimento, para a criação de novas habilidades, de novos hábitos e práticas de múltiplas atividades, tanto de natureza física, como também intelectual, social e cultural, enquanto vivências autorrealizadoras, autoconscientizadoras e autotransformadoras. Tal expectativa vem ganhando ênfase em todas as áreas das ciências e para a sociedade, a partir do momento em que o envelhecimento populacional e a possibilidade de envelhecer bem e com qualidade de vida se tornou uma realidade para muitos países.

Contudo, embora os estudos atuais apontem uma visão mais otimista em relação à velhice, a conquista da longevidade neste século XXI e a constatação de uma crescente população de idosos nas próximas décadas não deixa de impor desafios aos governantes, às organizações e à sociedade civil, implicando a 
responsabilização, a participação e o engajamento de todos, pois atrelados à esta conquista ainda existem aspectos que precisam ser desvendados e desmistificados, a fim de possibilitarmos a esta população que está envelhecendo uma ótima qualidade de vida, não só do ponto de vista biofisiológico, mas também social e cultural, que são aspectos inteiramente responsáveis pela preservação do bem-estar e pela integralidade do ser humano. É perceptível a discriminação e o preconceito para com o indivíduo idoso, que relacionados a aspectos negativos como a debilidade física, mental e às perdas funcionais, reforçam sentimentos de inadequação e baixa-estima, condicionando-o a situações de isolamento, levando-o a não viver essa etapa da vida de forma plena, expressiva e prazerosa, como deveria ser. $\mathrm{O}$ idoso continua ainda a ser avaliado como menos produtivo, menos seguro, menos estável, menos capaz de enfrentar desafios, arcaico em relação aos avanços e às mudanças tecnológicas, conservador, inadequado, mais propenso a acidentes e portador de dificuldades e limitações. Mediante Paz (2011), todas estas características negativas fazem com que a vivência da velhice se torne uma ameaça para o bem-estar e para a autoestima do indivíduo, levando-o a abrir mão dos seus sonhos, dos seus objetivos, dos seus projetos pessoais e a perder a força e o entusiasmo para seguir com a vida. Conforme o referido autor, estas são algumas das razões que levam muitos idosos a se isolar, a levar uma vida anti-social e a elaborar uma personalidade solitária, afastada da realidade e do mundo. Se dominados por conceitos negativos, os idosos se veem rodeados por um ambiente hostil e ameaçador, perdem o seu prestígio e o seu sentido de utilidade, desconfiam de tudo, se acham incapazes e incompetentes, se sentem escravos da vontade dos outros, sentem que qualquer esforço é inútil e que na vida nada mais vale a pena, demonstrando comportamentos de frustração, ressentimento e desamparo. Não obstante, independente dos sentimentos relacionados à velhice, se positivos ou negativos, o que se verifica ainda é que para a maioria dos indivíduos essa etapa da vida vem acompanhada de temores sobre o que se passará nos anos seguintes, de receios ligados ao pressentimento de inutilidade, de sentir-se deslocado e isolado, contribuindo, deste modo, para que a ansiedade e a angústia se instalem.

Ao discursar na II Assembléia Mundial sobre o Envelhecimento - realizada em 2002 pela Organização das Nações Unidas (ONU), em Madrid/ Espanha - o então Secretário-geral da ONU, Sr. Kofl Annan, enfatizou que o envelhecimento 
populacional global é um fenômeno excepcional e com decorrências para cada sociedade, cada instituição e cada pessoa, convertendo-se em um tema dominante neste século XXI. Segundo o Secretário-geral, é preciso incentivarmos e apoiarmos as iniciativas interdisciplinares e intersetoriais, centradas em equipes pluridisciplinares e em recursos humanos devidamente capacitados. É de nossa responsabilidade contribuirmos para que seja reforçada a construção de uma nova consciência que busque quebrar com os tabus e mitos erigidos sobre a velhice, a fim de superarmos as imagens negativas, discriminatórias e preconceituosas construídas socialmente acerca da pessoa idosa. É de responsabilidade da sociedade, principalmente das instâncias produtoras de políticas de envelhecimento, garantir que os idosos possam continuar ativos em suas respectivas culturas, com dignidade, sem discriminação, em condições de igualdade e como cidadãos com plenos direitos.

De acordo com Manuel Cuenca (2009), na contemporaneidade, quando vivemos o fenômeno da longevidade, valorizar o ócio no contexto social atribuído à velhice torna-se um aspecto primordial e extremamente importante. Nesta fase da vida - muitas vezes caracterizada pela inatividade, pelo tédio, pela insatisfação e pela solidão - o ócio irá assumir uma importância ainda maior, visto que vivenciar experiências satisfatórias e em maior profundidade pode ajudar 0 indivíduo a se identificar, a se conhecer, a se realizar, a se sentir melhor, a sair da rotina, a fantasiar, a perceber a vida como algo positivo de finalidade e sentido, a recuperar o equilíbrio das frustrações, a enfrentar com mais otimismo a sua nova situação social, a assumir outras atitudes perante a vida e a exercer o papel de protagonista da sua própria existência.

Diferentemente do entendimento geral atribuído ao termo, o referido autor, que introduziu na concepção de ócio o perfil humanista, compreende o ócio como uma experiência gratuita, desejada, suave, prazerosa e gratificante, pautada no sentimento de liberdade, de satisfação, de felicidade e de bem-estar pessoal, e que se diferenciará das demais experiências pela sua capacidade de sentido e potencialidade de encontros criativos. O ócio, enquanto fruto das horas vagas, do descanso e da tranquilidade, representa uma condição da existência humana, que tem como propósito capital alcançar a felicidade. Falar de ócio é falar de uma experiência integral, necessária e enriquecedora da natureza humana, relacionada com o mundo da subjetividade, da emotividade, do conhecimento, da 
reflexão, da contemplação e da criatividade. Falar de ócio é falar de uma experiência voltada para o desenvolvimento psicofísico e para o enriquecimento intelectual, cultural e espiritual. É falar de uma experiência que vai surgir da escolha, da identificação, da abertura, da entrega, da apreciação e da percepção daquele que a vivencia, independentemente da atividade em si, da duração de tempo, do nível sócio-econômico e da formação daquele que a realiza (Cuenca, 2009).

Segundo o autor supracitado, a decisão de como melhor ocupar o tempo e torná-lo mais satisfatório e prazeroso, a partir de ocupações que realmente confiram sentido, é de extrema importância para a manutenção do bem-estar psicofísico e da subjetividade. O desfrute da velhice "está relacionado com a forma de ser e com as escolhas específicas, que determinam uma maneira de ver a vida e as relações com os demais" (Cuenca, 2009, p. 253). Como em qualquer outra fase da vida, na velhice também é fundamental que o indivíduo busque novas formas de ocupação, novos caminhos, novos objetivos, novos desafios, novos interesses e novas experiências, que venham conferir sentido à sua existência e aumentar a sua capacidade de viver bem e feliz.

Fonseca (2004) assinala que na velhice as novas ocupações e as novas possibilidades de comunicação, de ampliação cultural e de participação grupal, entre outras atividades voltadas para a manutenção do lazer, deverão ser colocadas em primeiro plano e ganhar um papel de relevo no cotidiano do indivíduo. Mediante o referido autor, cabe ao próprio indivíduo buscar reestruturar, de forma inovadora, o seu dia-a-dia, a fim de substituir aquelas atividades que lhe eram significativas, exercidas no decorrer da sua vida ou do seu papel de trabalhador, por atividades igualmente satisfatórias, já que estas passarão a assumir o meio e o fim central para continuar a mantê-lo ativo, vivo, independente, autônomo e socialmente integrado. $\mathrm{Na}$ fase da velhice as atividades de caráter social, político, cultural, esportivo, recreativo e voluntariado serão de fundamental relevância para a adaptabilidade do indivíduo, além de determinantes para se garantir a satisfação, o otimismo e o entusiasmo nos anos futuros, contrariando todo o sentido de exclusão e inatividade, haja vista que permanecer ativo e participativo são condições necessárias e essenciais para se viver bem e com sucesso a velhice. O que não pode acontecer é o indivíduo carregar consigo o fardo de uma vida atrelada à ausência de sentido. 
A partir do referencial teórico apreendido levantamos as seguintes questões de investigação: A aplicação de um Processo de Criação do Clown num contexto social atribuído à velhice pode possibilitar bem-estar e potencializar a vida? As atividades que atravessam este processo podem ser percebidas como possibilidades de experiências de ócio? E é embasado nestas duas questões de investigação que situamos o nosso objeto de estudo - $O$ "clownear" enquanto experiência lúdico-criativa potencializadora da vida na velhice - de reflexão interdisciplinar, predominantemente qualitativo e de caráter artístico-social, desenvolvido no âmbito dos Estudos Culturais.

\section{2- Objetivos}

Por se tratar de um estudo implicado no diálogo com a própria empiria, buscamos organizar os objetivos, geral e específicos, da seguinte forma:

\section{Geral:}

Verificar de que forma um Processo de Criação do Clown aplicado com idosos pode possibilitar bem-estar e vida com qualidade.

\section{$>$ Específicos:}

- Conceber um programa interventivo;

- Desenvolver um cronograma de execução;

- Estabelecer um protocolo com um Centro de Dia;

- Implementar o programa;

- Formar um grupo representativo de idosos;

- Elaborar um "Sistema de atividades";

- Executar as atividades;

- Conferir os efeitos resultantes do programa. 


\section{3- Justificativa}

Como já referimos na introdução desta tese, o desafio de testarmos um processo de criação do clown com idosos pode resultar numa nova hipótese para a retomada e recriação de valores considerados essenciais e preditivos para uma velhice bem-sucedida, como a liberdade, a satisfação, o humor, a autonomia, a autoestima, o autoconhecimento, a autoaceitação, a autoexpressão e a autorrealização. Todos estes valores, segundo Cuenca (2009), são considerados critérios inquestionáveis para se garantir um grau elevado de disposição emocional, uma individualidade saudável e uma vida social equilibrada, tanto no âmbito pessoal como comunitário, e apontam diretamente para o ócio e para as reivindicações urgentes e próprias da velhice, como a longevidade, a saúde, a eficácia cognitiva, a competência social, o bem-estar e a satisfação com a vida.

De acordo com Burnier (2001) e Ferracini (2003), todo processo de criação do clown é atravessado por atividades e técnicas diversas, constituídas por procedimentos específicos de relação com a alteridade. Trata-se de um processo que vai implicar um estado de abertura, de liberdade, de generosidade e de vulnerabilidade, extremamente necessários para se atingir a pureza, a ingenuidade, a fragilidade, a espontaneidade e a alegria de um clown, como também o confronto entre a "máscara" que esconde a pessoa do sujeito e a essência do seu próprio ser. Segundo os referidos autores, o clown não se representa, ele "é", não se trata de um personagem, como tal, construído como uma caricatura separada daquele que o desempenha. O clown é pessoal, único e intransferível. O termo pessoal vai evocar no sujeito o exercício da exposição da sua própria singularidade para a criação do seu clown: refere-se à exposição e dilatação dos seus aspectos ingênuos, puros e humanos, como também do seu lado patético e ridículo de ser, tão bem camuflados; refere-se à criação de uma lógica própria, de maneiras peculiares de agir, pensar e sentir; refere-se à busca da compreensão do seu modo pessoal e específico de jogo e de relação, da produção de si, do [re] inventar-se.

O clown é um tipo cômico que joga o tempo todo e é na intensidade, na capacidade de excitação e no poder de fascinação do jogo que reside a sua essência, o divertimento, pois a alegria do clown está intrinsecamente ligada a qualquer "coisa brincante". Neste jogo de "perguntas e respostas" o que dá 
suporte, substancializa e sustenta a atuação do clown é o que muitos estudiosos denominam de estado de clown, percebido neste estudo como sendo um "estado de divertimento puro". Este estado, visto também como uma condição particular de prontidão e comunicabilidade, é que integra o sujeito aos acontecimentos imediatos e às necessidades do momento, levando-o a experienciar um modo pessoal e específico de relação e de jogo, a partir do próprio corpo e das demais situações de interação, numa situação de representação. Os pilares que dão sustentação a este estado, responsáveis também pelo preenchimento, justificativa, veracidade e organicidade da performance do clown, são: o jogo; a brincadeira; a imaginação; a criação; o prazer e a alegria. $O$ que o sujeito experimenta ao atingir este estado é o emergir de outras possibilidades de ser, estar e fazer até antes não acessadas, além da sensação de que tudo é permitido ao seu clown. (Burnier, 2001; Ferracini, 2003; Kleber, 2012; Machado, 2005).

\section{4- Domínio de investigação: Estudos Culturais}

Buscaremos, a seguir, esboçar alguns traços da trajetória histórica dos Estudos Culturais (EC), como também apresentar os seus antecedentes e fazer uma incursão, breve e delineada, dos contornos que este campo de estudos vem assumindo na atualidade.

Os Cultural Studies, segundo Martins (2015), são uma tradição epistemológica das Ciências Humanas e Sociais, que desde a década de 60 e 70 do século XX, na Inglaterra, transferiu a reflexão sobre a cultura, centrada na relação cultura/nação e no privilégio dado ao ensino da Sociologia, da Literatura, da História e das Línguas, para uma aproximação da cultura com os modos de vida dos grupos sociais.

De acordo com Escosteguy (2010), as primeiras manifestações dos Estudos Culturais (EC) se originam no final dos anos 50 , especialmente em torno dos trabalhos de Richard Hoggart, Raymond Williams e Edward Palmer Thompson, preocupados com a questão da cultura na sociedade estratificada em classes da Inglaterra, marcada pelo fim da segunda guerra mundial. Estes três autores, apontados como os fundadores dos Cultural Studies, ainda que não tivessem uma intervenção coordenada entre si, "revelam um leque comum de 
preocupações que abrangem as relações entre cultura, história e sociedade" (Escosteguy, 2010, p. 31). Os textos produzidos por estes três autores são: The Uses of Literacy (Hoggart, 1957); Culture and Society (Williams, 1958); e The Making of the English Working-class (Thompson, 1963).

\begin{abstract}
O primeiro é em parte autobiográfico e em parte história cultural do meio do século XX. O segundo constrói um histórico do conceito de cultura, culminando com a ideia de que a "cultura comum ou ordinária" pode ser vista como um modo de vida em condições de igualdade de existência com o mundo das Artes, Literatura e Música. E o terceiro reconstrói uma parte da história da sociedade inglesa de um ponto de vista particular - a história "dos de baixo". (Escosteguy, 2010, pp. 27-28)
\end{abstract}

Estes textos, identificados como a base dos Cultural Studies, apesar de não estarem centrados em torno dos mesmos propósitos e de não apresentarem uniformidade em suas perspectivas de problematização, estão unidos por uma abordagem cuja preocupação recai sobre a importância de se analisar a produção cultural de uma sociedade, com ênfase no seu significado político, para se entender os padrões de comportamento e as ideias compartilhadas pelos indivíduos que nela vivem (Costa et al. 2003).

Do ponto de vista histórico, os Cultural Studies vão surgir, de forma organizada e institucionalizada, em 1964, quando Richard Hoggart - professor de Literatura Moderna de Língua Inglesa - funda o Centre for Contemporary Cultural Studies (CCCS), constituído como um centro de pós-graduação ligado ao English Department da Universidade de Birmingham, diante da alteração dos valores tradicionais da classe operária britânica do pós-guerra. Um quarto membro, não menos importante, do início da configuração deste campo de estudos, foi Stuart Hall, que apesar de não ser citado entre os três autores fundadores dos Cultural Studies também teve uma participação unanimemente reconhecida na sua constituição, com uma abundante produção de artigos, que compõem parte da maioria das coletâneas mais importantes sobre os Estudos Culturais. Avalia-se que, ao substituir Richard Hoggart na direção do Centre for Contemporary Cultural Studies (CCCS) - de 1968 a 1979 - Stuart Hall incentivou o desenvolvimento de investigações de práticas de resistência de subculturas e análises dos meios 
massivos, tornando-se um dinamizador de inumeráveis projetos coletivos. Mais a mais, Hall também destravou inúmeros debates teórico-políticos, desempenhando a função de "aglutinador" em momentos de intensas distensões teóricas (Escosteguy, 2010).

Conforme a referida autora, é possível identificarmos duas grandes reorientações na análise cultural proposta pelos Cultural Studies: a primeira reporta a um amplo espectro de práticas e significados que constituem e movem a vida social, ou seja, aquilo que era considerado "sério" na área das artes, da música e da literatura passa a ser percebido apenas como "uma" expressão da cultura; já a segunda mudança, esta reporta ao alargamento do conceito de cultura, incluindo práticas da vida cotidiana, onde todas as expressões culturais passam a ser vistas de acordo com o contexto social das instituições, das relações de poder e da história. Deste modo, "cultura deixa, gradativamente, de ser domínio exclusivo da erudição, da tradição literária e artística, de padrões estéticos elitizados e passa a contemplar, também, o gosto das multidões" (Costa, Silveira \& Sommer, 2003, p. 36).

\begin{abstract}
Analistas contemporâneos da cultura chamam a atenção para a ocorrência de uma "revolução cultural", ao longo do século XX, na qual os domínios do que costumamos designar como cultura se expandiram e diversificaram de uma forma jamais imaginada. A cultura não pode mais ser concebida como acumulação de saberes ou processo estético, intelectual ou espiritual. A cultura precisa ser estudada e compreendida tendo-se em conta a enorme expansão de tudo que está associado a ela, e o papel constitutivo que assumiu em todos os aspectos da vida social (Costa et al., 2003, p. 38).
\end{abstract}

O termo cultura converte-se de um conceito impregnado de estilismo, hierarquia $^{51}$ e categorias separatistas para um outro eixo de significados, incorporando novas e diferentes possibilidades de sentidos, mais cambiantes e

\footnotetext{
${ }^{51}$ Alta cultura e cultura de massa, cultura burguesa e cultura operária, cultura erudita e cultura popular: o primeiro termo corresponderia à cultura entendida como a máxima expressão do espírito humano; e o segundo, como as culturas adjetivadas e singulares, como a expressão de manifestações supostamente menores e sem importância no cenário elitista. "É, então, a essa concepção elitista - em que cultura é um certo 'estado cultivado do espírito', que estaria em oposição 'à exterioridade da civilização' - que os EC vão se contrapor" (Costa et al. 2003, p. 38).
} 
versáteis. Conforme Barker e Beezer ${ }^{52}$ (1994 como citado em Costa et al. 2003, p. 37), o projeto inicial dos Estudos Culturais britânicos foi o de "pensar as implicações da extensão do termo 'cultura' para que inclua atividades e significados das pessoas comuns, esses coletivos excluídos da participação na cultura quando é a definição elitista que a governa". Deste modo, as relações entre as formas e práticas culturais, sociedade e estruturas sociais passarão a compor o eixo principal de pesquisa nos Estudos Culturais.

$\mathrm{Na}$ sua fase embrionária, que se inicia com os textos precursores, já citados, os EC vão se fundamentar na relação com as iniciativas políticas, como também na relação com os diversos movimentos sociais e com as diversas disciplinas para a observação da cultura popular ${ }^{53}$. Até o final da década de $70 \mathrm{e}$ início dos anos 80 , fase de consolidação, os EC passam a se assentar na compreensão das relações entre poder, ideologia e resistência ${ }^{54}$. Já nos meados dos anos 80 e anos 90, fase de internacionalização dos EC, a agenda original desta tradição vai se transformando. Nesta fase os EC passam a dar ainda mais ênfase à ação social, ao contexto, à experiência, às especificidades, dando voz aos significados que se fazem aqui e agora, à luz das relações de identidade, tanto no âmbito global, nacional e local, como também individual, produzindo, desta maneira, uma teoria engajada nas diferenças culturais (Escosteguy, 1998).

(...) os estudos culturais devem ser vistos tanto do ponto de vista político, na tentativa de constituição de um projeto político, quanto do ponto de vista teórico, isto é, com a intenção de construir um novo campo de estudos. Do ponto vista político, é sinônimo de "correção política", podendo ser identificado como a política cultural dos vários movimentos sociais da época de seu

\footnotetext{
52 Barker, M., Beezer, A. (eds.) (1994). Introducción a los estudios culturales. Barcelona: Bosch Casa Editorial. Tradução de Héctor Borrat.

${ }^{53}$ Nesta fase "os estudos culturais questionam a produção de hierarquias sociais e políticas a partir de oposições entre tradição e inovação, entre a grande arte e as culturas populares, ou, então, entre níveis de cultura - por exemplo, alta e baixa, cultura de elite e cultura de massa. A consequência natural desse debate é a revisão dos cânones estéticos ou mesmo de identidades regionais e nacionais que se apresentam como universais ao negarem ou encobrirem determinações de raça, gênero e classe" (Escosteguy, 2010, p. 47).

54 De forma sintética, pode-se entender o centro de Birmingham, da sua fundação ao início dos anos 80 , como foco irradiador de uma plataforma teórica derivada de importações e adaptações de diversas teorias; como promotor de uma abertura a problemáticas antes desconsideradas como as relacionadas às culturas populares e aos meios de comunicação de massa e, mais tarde, a questões vinculadas às identidades étnicas e sexuais; e como divulgador de estudos bastante heterogêneos decorrentes da diversidade de referências teóricas, assim como, da pluralidade das temáticas estudadas (Escosteguy, 1998, p. 91).
} 
surgimento. Da perspectiva teórica, resultam da insatisfação com os limites de algumas disciplinas, propondo, então, a interdisciplinaridade (Escosteguy, 1998, p. 88).

De acordo com Baptista (2009), o Centre for Contemporary Cultural Studies $^{55}$ (CCCS) teve como base a cooperação entre as diversas áreas do conhecimento, buscando estimular a investigação em interdisciplinaridade, ou seja, buscando tecer relações com outros territórios disciplinares. Desta maneira, os Estudos Culturais vão se instituir como um desafio à construção de uma cultura de diálogo entre as diferentes disciplinas, como um domínio intelectual transdisciplinar, transitando por vários campos temáticos e teorias, abrigando um conjunto de múltiplos investigadores ${ }^{56}$ e sugerindo múltiplas possibilidades de cruzamento, através do uso de paradigmas teóricos, metodológicos e estilísticos diversos. E mais, os Estudos Culturais também vão se caracterizar pela multiplicidade de objetos de investigação de origens acadêmicas e geográficas diversas, haja vista que este campo de estudos oferece um espaço no qual se pode pesquisar e refletir diferentes questões. Graeme Turner ${ }^{57}$ (1990 como citado em Escosteguy 2010, p. 34), aponta que os Estudos Culturais é um campo de estudos interdisciplinar onde certas preocupações e métodos se convergem. "A utilidade dessa convergência é que ela nos propicia entender fenômenos e relações que não são acessíveis através das disciplinas existentes. Não é, contudo, um campo unificado". De acordo com Costa et al. (2003, p. 40),

Os Estudos Culturais não pretendem ser uma disciplina acadêmica no sentido tradicional, com contornos nitidamente delineados, um campo de produção de discursos com fronteiras balizadas. Ao contrário, o que os tem caracterizado é serem um

${ }^{55} \mathrm{Em} 2002$ o CCCS (que foi, entretanto, transformado em Department of Cultural Studies and Sociology) encerra as suas atividades, apesar do crescente interesse pelos Estudos Culturais em todo o mundo (Baptista, 2009, p. 455).

${ }^{56}$ Entre as diversas formações dos investigadores que trabalham nesta área, destacam-se aqueles que são oriundos dos Estudos Literários, Linguística, Sociologia, História, Antropologia, Comunicação, Geografia, Estudos Fílmicos, Psicologia, Educação e Filosofia; menos presentes, mas por vezes participantes empenhados no desenvolvimento de projetos de investigação em Estudos Culturais encontram-se economistas, juristas e peritos em relações internacionais (Baptista, 2009, pp. 455-456).

57 Turner, G. (1990). British Cultural Studies - An Introduction. Boston: Unwin Hyman. 
conjunto de abordagens, problematizações e reflexões situadas na confluência de vários campos já estabelecidos, é buscarem inspiração em diferentes teorias, é romperem certas lógicas cristalizadas e hibridizarem concepções consagradas.

Retrocedendo às suas origens, os Estudos Culturais, de uma forma geral e abrangente, circunscreveram-se a interesses e temas ligados às subculturas, aos meios de comunicação de massa, à recepção e densidade dos consumos mediáticos, às diferenças de gênero, às questões que envolvem raças e etnias, às novas modalidades de análise de comunicação social e às identidades, fossem elas de classe, sexuais, geracionais, etnográficas e culturais. Posteriormente, às temáticas relacionadas com as novas tecnologias, com a pós-modernidade, com a globalização, com a força das migrações, com o papel do Estado-nação e da cultura nacional, como também com o colonialismo e pós-colonialismo, com a nova sociedade em rede, com os choques civilizacionais, com a crise ambiental global, entre outros temas, resultando numa importante massa de resultados de grande qualidade e relevância dentro e fora das academias (Baptista, 2009; Escosteguy, 2010). Costa et al. (2003) aponta que os Estudos Culturais disseminaram-se nas Ciências Sociais, nas Humanidades, nas Artes, na Tecnologia, entre outras áreas, se aportando nos mais variados campos e se apropriando de teorias e metodologias da Filosofia, da Psicologia, da Antropologia, da Ciência Política, da Linguística, da Crítica Literária, da Teoria da Arte, da Musicologia, entre outras disciplinas, para darem conta de seus interesses e de suas preocupações, utilizando também da etnografia, da psicanálise, da análise do discurso e textual, e de tantos outros caminhos investigativos que são inventados para poderem compor seus objetos de estudo.

Um outro aspecto altamente positivo dos Estudos Culturais, segundo Ortiz (2004), é o fim das fronteiras tradicionalmente instituídas nos departamentos e nas universidades. Ortiz salienta que apesar deste campo de estudos ser caracterizado pela sua dimensão multidisciplinar, não podemos pensar a importância da multidisciplinaridade como algo igual à quebra das fronteiras. Em contrapartida, enfatiza o autor, também não podemos esquecer que as fronteiras são extremamente importantes para a produção de um saber mais autônomo, independentemente das pressões externas. 
A multidisciplinaridade não é, pois, um valor em si, mas um valor relacional (isto é, estabelece-se em relação às "verdades" disciplinares), e é preciso, portanto, vinculá-la a uma questão anterior: em que medida ela favorece ou não uma realização mais adequada do próprio pensamento. Se os Estudos Culturais propõem uma solução multidisciplinar, não é menos certo que outras alternativas podem também ser exploradas, por exemplo, a transdisciplinaridade. Nesse caso, os horizontes disciplinares surgem não como um entrave a ser abolido, mas como ponto de partida para uma "viagem" entre saberes compartimentados (Ortiz, 2004, p. 122).

Nos resta dizer que, se os Estudos Culturais, originalmente, são considerados uma invenção britânica, na atualidade este campo de estudos não se confina mais à Inglaterra, Europa ou EUA, transformando-se, na sua forma contemporânea, num fenômeno de repercussão internacional, se espalhando para o Canadá, América Latina, Austrália, Nova Zelândia, África e Ásia. "Isto não significa, no entanto, que exista um corpo fixo de conceitos que pode ser transportado de um lugar para o outro e que opere de forma similar em contextos nacionais ou regionais diversos" (Escosteguy, 2010, p. 87).

A partir da década de 80 e 90, de acordo com Baptista (2009), verifica-se a institucionalização dos Estudos Culturais em diversas partes do mundo, com um desenvolvimento singular, colaborando para a implosão das fronteiras estabelecidas entre as diversas áreas disciplinares e estabelecendo departamentos, programas acadêmicos, centros de investigação, revistas e organizações profissionais.

Em consequência deste rápido e prodigioso desenvolvimento, os Estudos Culturais passaram a apresentar-se como uma prática intelectual dispersa, cujo único centro talvez tenha passado a ser o de procurar articular e fazer dialogar três nós problemáticos essenciais: cultura, teoria e ação cívica. Não obstante esta dimensão de fragmentação e pulverização, foi-se assistindo, paralelamente, ao nascimento dos Estudos Culturais como uma área mais circunscrita e institucionalizada, gozando de reconhecimento académico num número limitado, mas crescente, de países (Baptista, 2009, p. 454). 


\section{5- O método da pesquisa-ação como estratégia de pesquisa}

Não temos a pretensão de apontar e discutir as divergências e as convergências que animam a proposta da pesquisa-ação, haja vista as várias interpretações e mudanças que vieram modificando a concepção original de Kurt Lewin. Pretendemos apenas trazer à tona algumas informações relacionadas à aplicação deste método, ressaltando suas principais características.

Kurt Lewin, buscando fundamentar seus interesses e trabalhos de investigação, desenvolveu em 1946 um método de investigação o qual denominou pesquisa-ação, que tem como ponto central a informação, a interação e a colaboração. Esta estratégia de pesquisa é uma maneira de testar e comprovar ideias a partir da prática, como forma de desenvolver o conhecimento acerca de uma determinada temática. Na sua concepção a pesquisa-ação compreende quatro fases: planejamento, ação, observação e reflexão.

Nos seus estudos sobre a pedagogia da pesquisa-ação, Thiollent (1992) aponta que esta forma de pesquisa pode ser interpretada como um modo de conceber e de organizar uma investigação de caráter social com finalidade prática, que esteja inteiramente de acordo com as exigências próprias da ação e da participação dos sujeitos na situação observada. $O$ referido autor define a pesquisa-ação como sendo "um tipo de pesquisa social com base empírica que é concebida e realizada em estreita associação com uma ação ou com a resolução de um problema coletivo e no qual os pesquisadores e os participantes representativos da situação ou do problema estão envolvidos de modo cooperativo ou participativo" (Thiollent, 1992, p. 14). Considera, também, que a estrutura metodológica da pesquisa-ação dá lugar a uma ampla diversidade de propostas de pesquisa nos múltiplos campos de atuação social.

Segundo Franco (2005), falar de pesquisa-ação é falar de um processo que deve gerar transformações de sentido e atribuição de novos significados acerca do que fazemos ou pensamos, ou seja, da apropriação das mudanças que se produzem em suas significações de mundo e que implicam, fundamentalmente, mudanças de perspectivas e de reconstrução do próprio sujeito; de um processo implicado na participação ativa dos indivíduos envolvidos, inclusive do pesquisador, cabendo a ele assumir os dois papéis, de pesquisador e de participante. 
A ideia de pesquisa-ação também encontra um contexto favorável quando o investigador não pretende limitar seus estudos aos aspectos acadêmicos das pesquisas convencionais, mas quando almeja uma pesquisa na qual as pessoas implicadas tenham algo a "dizer" e "fazer", e onde ele possa desempenhar um papel ativo na própria realidade dos contextos observados. Mediante Engel (2000, p.182), em oposição à pesquisa tradicional, a pesquisa-ação surgiu da necessidade de suplantar a lacuna entre a teoria e a prática. Segundo o autor, "uma das características deste tipo de pesquisa é que através dela se procura intervir na prática de modo inovador já no decorrer do próprio processo de pesquisa e não apenas como possível consequência de uma recomendação na etapa final do projeto", ou seja, esta metodologia procura desenvolver a construção do saber a partir da prática, onde pesquisa e ação estão reunidas, a partir da integração de processos de pesquisa, formação e reflexão.

De acordo com o autor supracitado, a pesquisa-ação também agrega varias técnicas da pesquisa de estrutura coletiva, interativa e ativa, ao nível da captação de informação. Independente das técnicas a serem aplicadas ela deve caminhar para uma metodologia que instaure no grupo uma dinâmica de princípios e práticas participativas, transformadoras e dialógicas. Além do mais, o método da pesquisa-ação possui grandes possibilidades de aplicação, podendo ser desenvolvido em qualquer ambiente de interação social, fundamentada na confiança, no comprometimento, na cumplicidade e na liberdade de expressão.

\section{6-Técnicas para coleta de dados}

As técnicas utilizadas para coleta de dados em uma pesquisa científica, segundo Ribeiro (2008), se inserem de acordo com a definição metodológica. Neste estudo, onde foi proposto o método da pesquisa-ação como estratégia de pesquisa, buscamos utilizar como procedimentos de coleta de dados a entrevista focalizada, a técnica de observação participante e o diário de bordo, com a finalidade de obtermos informações que não nos seriam possíveis somente através da pesquisa bibliográfica.

Como alternativa às entrevistas semi-estruturadas optamos pela entrevista focalizada. De acordo com Ribeiro (2008), nas entrevistas semi-estruturadas as 
questões geralmente são formuladas de modo a permitir que o entrevistado discorra e verbalize os seus pensamentos, os seus sentimentos, etc. Com frequência o questionamento é mais profundo, como também mais subjetivo, e muitas vezes diz respeito a uma avaliação de valores, de crenças, de atitudes, de razões e de motivos, acompanhados de fatos e comportamentos. A referida autora aponta que os pontos fortes das entrevistas semi-estruturadas são: a flexibilidade na aplicação; a facilidade de adaptação de protocolo; a viabilização da comprovação e esclarecimento de respostas; a taxa de respostas elevadas; e o fato de a entrevista poder ser aplicada a pessoas não aptas à leitura e à escrita.

\begin{abstract}
A entrevista é a técnica mais pertinente quando o pesquisador quer obter informações a respeito do seu objeto, que permitam conhecer sobre atitudes, sentimentos e valores subjacentes ao comportamento, o que significa que se pode ir além das descrições das ações, incorporando novas fontes para a interpretação dos resultados pelos próprios entrevistadores. (Ribeiro, 2008, p. 141)
\end{abstract}

$\mathrm{Na}$ entrevista focalizada, segundo Guerra (2006), o investigador, a partir de um roteiro de tópicos concernentes à problemática que se vai investigar, tem a liberdade de fazer as perguntas que forem necessárias, podendo sondar razões e dar esclarecimentos, não obedecendo, a rigor, a uma estrutura formal. Este tipo de entrevista pode possibilitar até mesmo a inclusão de perguntas não previstas, mais diretas, flexíveis e espontâneas, o que favorece ainda mais a inter-relação entre o entrevistador e o entrevistado. Conforme Ribeiro, a interação de confiabilidade entre o investigador e o entrevistado é muito importante, "sem a afirmação da interação não se desenvolve o diálogo que possibilita ao entrevistado se abrir, ou seja, se 'desnudar' de qualquer tipo de couraça" (Ribeiro, 2008, pp. 143-144).

Empregamos também a técnica de observação participante, que nos permitiu a evidência de informações e dados não constantes na bibliografia, nas entrevistas e nos diários de bordo. De acordo com Burgess (1997), a observação participante possibilita ao investigador coletar dados numa situação social, baseados no que acontece, isto é, naquilo que o investigador vê e ouve. Segundo 
o autor, a vantagem de o investigador ser um observador participante reside na oportunidade de estar disponível para reunir dados pormenorizados e significantes, fundamentados na ocorrência da situação, além de poder obter relatos de situações na própria fala dos participantes. "Através da observação o investigador consegue documentar atividades, comportamentos e características físicas sem ter de depender da vontade e capacidade de terceiras pessoas" (Coutinho, 2013, p. 136). O resultado, aponta Burgess (1997), é que o observador participante pode utilizar suas próprias observações com as suas ferramentas teóricas, de forma a tornar compreensível, por exemplo, comportamentos detectados no contexto da situação social observada. Segundo Becker ${ }^{58}$ (1958 como citado em Burgess 1997, p. 86), "o observador participante reúne dados porque participa na vida cotidiana do grupo ou da organização que estuda. Ele observa as pessoas que estuda por forma a ver em que situações se encontram e como se comportam nelas".

Como técnica para coleta de dados lançamos mão também de um instrumento de suma importância, o diário de bordo, que serviu como registro das múltiplas percepções dos agentes implicados na pesquisa.

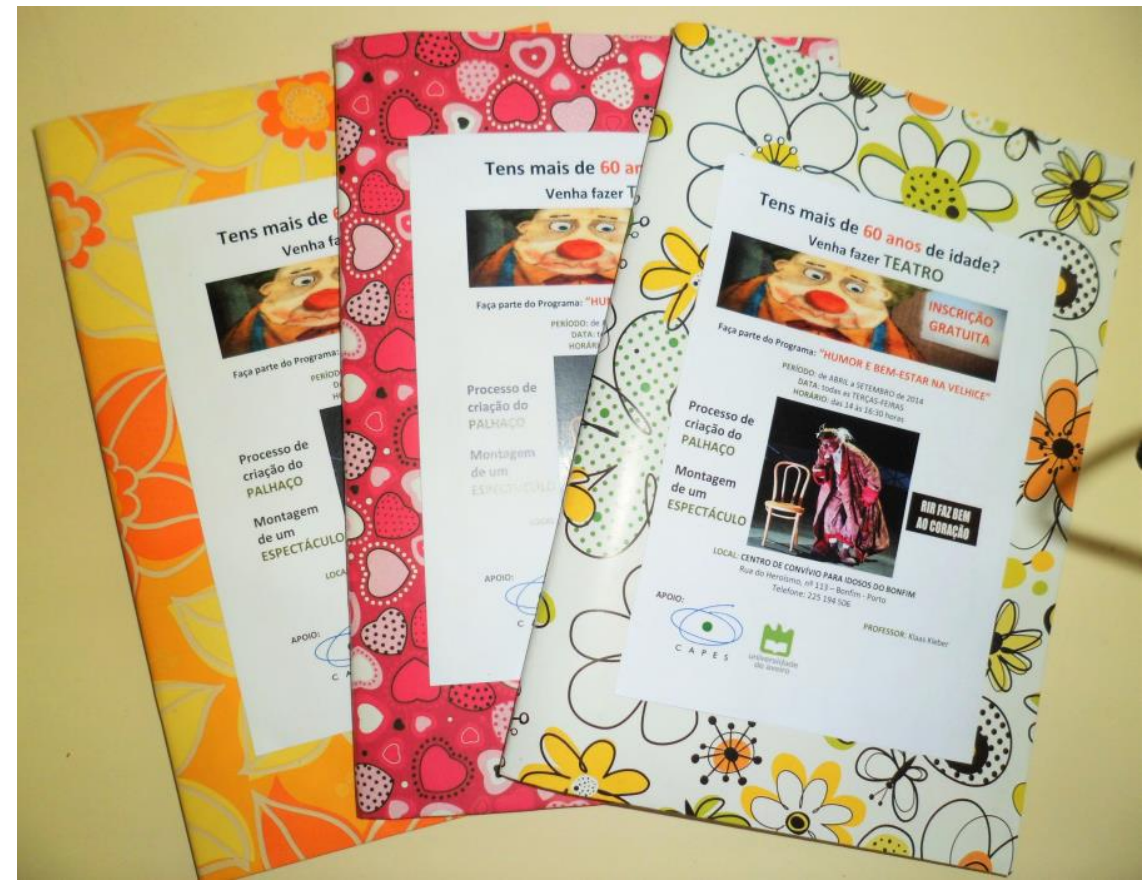

Imagem 03: Diário de Bordo

58 Becker, H. S. (1958). Problems of inference and proof in participant observation. American Sociological Review, vol. 23, ㄲo 6, pp. 652-660. 


\section{7- Diagrama de investigação}

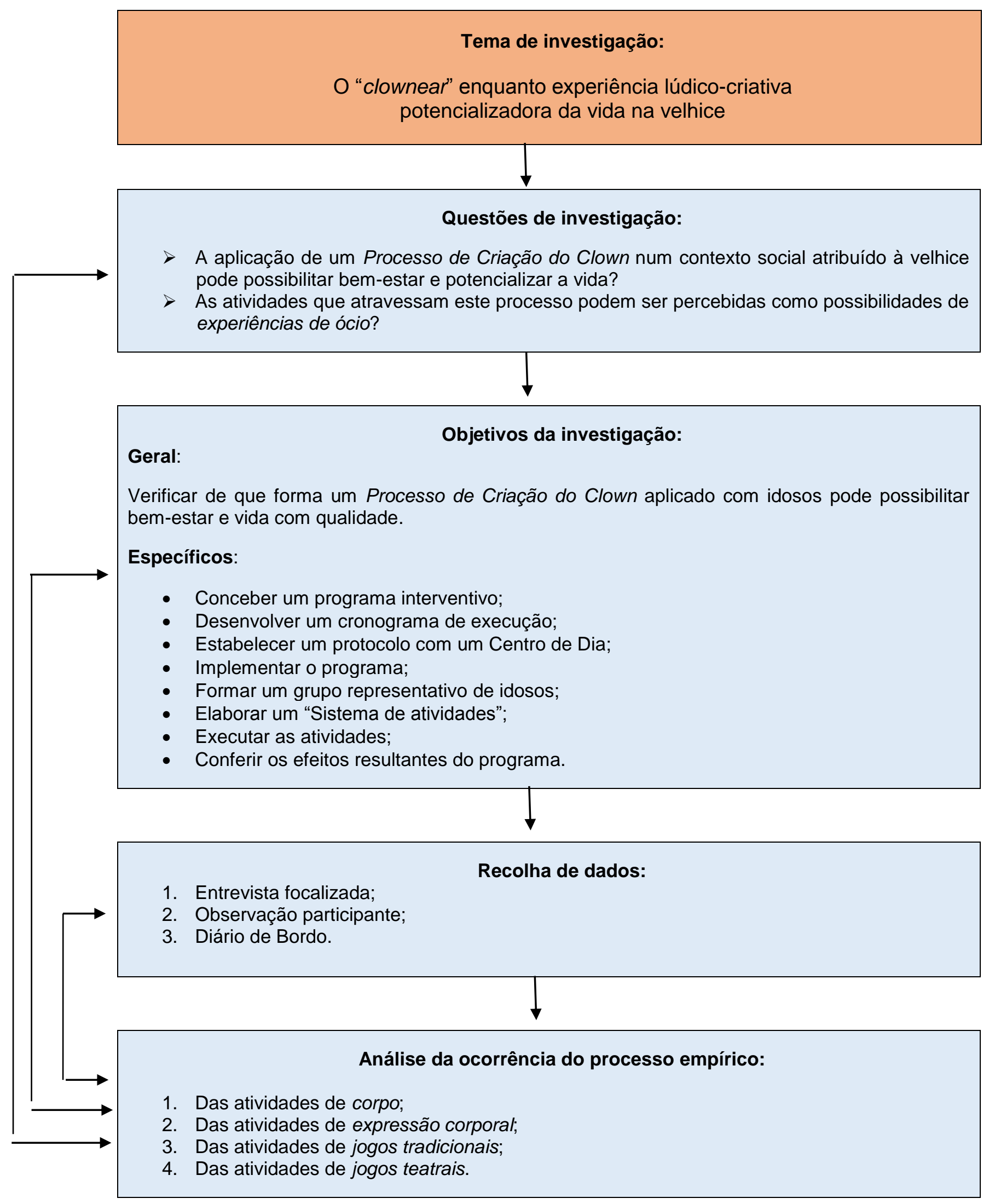

Figura 02: Diagrama de investigação 


\section{CAPÍTULO V}

\section{CORPUS EMPÍRICO}

\subsection{Desenho da pesquisa-ação}

Objetivando "investigar de que forma um processo de criação do clown aplicado com idosos pode possibilitar bem-estar e vida com qualidade", elaboramos um "plano de ação" com base nos referenciais teóricos de Thiollent (1992), Franco (2005) e Engel (2000) acerca da metodologia da pesquisa-ação, desenvolvida por Kurt Lewin, onde pesquisa e ação foram reunidas a partir da integração de processos de planejamento, ação, observação e reflexão.

\section{Etapa 01: PLANEJAMENTO}

Conceber um programa interventivo;

Desenvolver um cronograma de execução;

Elaborar um "Sistema de atividades".

\section{Etapa 04: REFLEXÃO}

Conferir os efeitos resultantes do programa, com base nos referenciais teóricos apreendidos e mesclando as informações obtidas por meio das entrevistas e diários de bordo com as percepções do investigador suscitadas no seu processo de observação.

\section{Etapa 02: AÇÃO}

Estabelecer um protocolo com um Centro de Dia; Implementar o programa;

Divulgar o programa; Inscrever os interessados;

Formar um grupo representativo de idosos;

Realizar uma entrevista;

Executar as atividades.

\section{Etapa 03: OBSERVAÇÃO}

Da realidade vivida pelos agentes nos contextos observados, a fim de obtermos provas que nos permitisse dar resposta às questões de investigação.

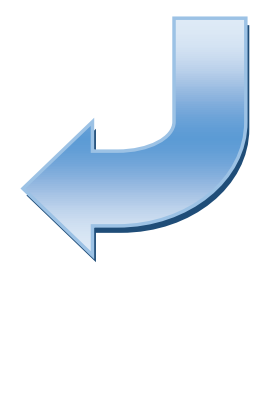

Figura 03: Plano de ação 


\section{2- O programa Humor e Bem-estar na Velhice}

Por se tratar de uma investigação que só produziria efeito no diálogo com a própria empiria, optamos pela metodologia da pesquisa-ação, em função da sua orientação prática e flexibilidade, onde pesquisa e ação foram reunidas a partir da integração de processos de planejamento, ação, observação e reflexão. 0 contexto favorável da pesquisa-ação deu-se ao fato de o investigador não se limitar somente aos estudos bibliográficos, mas de poder desenvolver uma ação com princípios e práticas participativas, transformadoras e dialógicas, onde os agentes implicados na pesquisa puderam desempenhar um papel ativo na realidade dos contextos observados e dizer algo acerca das suas experiências.

Deste modo, com base nos referenciais teóricos de Thiollent (1992), Franco (2005) e Engel (2000) acerca da metodologia da pesquisa-ação, desenvolvida por Kurt Lewin, elaboramos o nosso "plano de ação", que deu forma e sustentação ao programa interventivo intitulado Humor e Bem-estar na Velhice, concebido em função da temática a ser investigada, em função das características do grupo representativo da pesquisa e em função das exigências próprias e intrínsecas da ação.

Como estratégia operacional optamos por desenvolver um processo de criação do clown, atravessado por atividades e técnicas diversas - corpo, expressão corporal, jogos tradicionais, jogos teatrais e exercícios clássicos de clown - devidamente adaptadas à realidade dos sujeitos da pesquisa, visto se tratar de um grupo de pessoas com idades avançadas e bastante vulneráveis, suscetíveis a dificuldades e limitações corpóreas, dado o estado de saúde e a fragilidade física.

O nosso desafio consistiu em criarmos um espaço que propiciasse a interação social, a inclusão, a criação, a livre expressão, a aprendizagem, a reflexão, o desfrute, a diversão e a alegria, como também um espaço que facultasse as agentes a retomada e recriação de valores considerados essenciais para a manutenção do bem-estar, como a liberdade, a autonomia, a autoaceitação, a autoestima, o autoconhecimento, a autoexpressão, a autorealização e a imagem positiva de si. 


\section{3- Humor e bem-estar: conceitos chave na concepção de saúde}

Nas últimas décadas o enorme avanço das ciências da saúde tem contribuído de forma significativa para o aumento da longevidade dos indivíduos, contudo, segundo a Organização Mundial da Saúde (ONU, 2003), para se garantir uma velhice bem-sucedida é necessário muito mais do que recursos fisiológicos, haja vista que o significado de saúde não pode ser reduzido só e simplesmente à ausência de doenças e sofrimentos, mas também a um estado completo de bem-estar psicofísico e social.

De acordo com Siqueira e Padovam (2008), a partir das últimas décadas o conceito de bem-estar, que durante séculos foi merecedor da atenção de filósofos, encontrou seu espaço enquanto objeto de estudo no campo científico da psicologia. Desde então o seu conceito vem sendo estudado como um dos fatores essenciais para uma vida saudável e feliz. No campo psicológico as concepções mais ressaltantes sobre a definição de bem-estar podem ser organizadas a partir de duas perspectivas teóricas dominantes: a primeira, denominada bem-estar subjetivo [BES] (bem-estar hedônico), aborda o estado subjetivo de felicidade; a segunda, denominada bem-estar psicológico [BEP] (bem-estar eudemônico), investiga o potencial humano. Os estudos sobre BES e BEP vêm sendo desenvolvido, paralelamente e de forma articulada, no seio de um campo ainda maior, o da saúde, em particular, a saúde mental.

O BES é um conceito recente, caracterizado como abrangente e difuso, e tem suscitado o interesse generalizado de muitas vertentes da psicologia. Trata-se de uma categoria de fenômenos que adota uma visão de bem-estar como prazer ou felicidade e que abrange as respostas emocionais, domínios de satisfação e julgamentos globais de satisfação com a vida, sustentado pela avaliação de satisfações que as pessoas fazem das suas próprias vidas, a partir das suas experiências emocionais, baseadas nos seus valores, necessidades e crenças, como também no balanço entre afetos positivos e negativos. Mediante Siqueira e Padovam (2008, p. 202), "para que o balanço represente uma dimensão de BES, é necessário resultar em uma relação positiva entre as emoções vividas, qual seja a vivência de mais emoções positivas do que negativas no decorrer da vida". Ou seja, não se trata de identificar a presença contínua de sentimentos positivos no decorrer da vida, 
mas de detectar se as experiências vivenciadas pelo indivíduo foram entremeadas mais por emoções satisfatórias do que ao contrário, como também a frequência dessas emoções, não importando a intensidade.

Conforme Galinha e Ribeiro (2005), o campo de estudo sobre o BES busca considerar as diferenças individuais de bem-estar positivo, considerando os fatores que discernem as pessoas ligeiramente felizes, das moderadamente felizes e extremamente felizes. O BES é medido a partir das perspectivas e das experiências internas do próprio indivíduo, buscando focar estados de bemestar duradouros, formado por três componentes: a "experiência acumulada de afeto positivo", em domínios da vida salientes, que referencia a frequência de emoções positivas no sujeito, como o orgulho e o interesse; "experiência acumulada de afeto negativo", em domínios da vida salientes, que referencia a frequência de emoções negativas, como a hostilidade e a perturbação; e a "avaliação da satisfação com a vida global", determinada como uma avaliação cognitiva positiva da vida pessoal como um todo. Conforme Siqueira e Padovam (2008, p. 202), "para que seja relatado um nível de BES adequado, é necessário que o indivíduo reconheça manter em nível elevado a sua satisfação com a vida, alta frequência de experiências emocionais positivas e baixas frequências de experiências emocionais negativas". Mais a mais, para aceder o BES é fundamental considerar que cada indivíduo avalia sua própria vida a partir da aplicação de concepções subjetivas, formadas em pensamentos e sentimentos sobre a existência individual, apoiando-se em seus próprios valores, experiências, emoções e expectativas. O conceito de BES é algo que vem se alargando e adquirindo uma importância crescente, tendo em vista a expectativa de que as pessoas vivam sua vida de modo preenchido e segundo os seus próprios critérios.

O bem-estar psicológico [BEP], fundado nos anos 80 por Carol Ryff, inspirado no sentido aristotélico de felicidade, apoia-se no entendimento de que o estado de bem-estar consiste na forma de pensar do indivíduo e de se usar o bom senso. Suas concepções teóricas são construídas a partir de formulações psicológicas acerca do desenvolvimento humano e das capacidades para se enfrentar os desafios da vida. As proposições acerca do conceito de BEP surgiram como críticas à fragilidade das formulações que amparavam o conceito de BES e aos estudos psicológicos que ressaltavam o sofrimento e a 
infelicidade, negligenciando as razões e implicações do funcionamento positivo. Ryff (1989), uma das argumentadoras que busca dar sustentação às proposições de BEP, e cujos estudos são um marco na literatura sobre o tema, apoia-se nas várias teorias clássicas existentes em psicologia, tomando como referencial todas as compreensões teóricas que permitiam abstrair concepções diferenciadas acerca do funcionamento psicológico positivo, elaborando, a partir destes referenciais, um modelo de seis componentes de BEP, que foram reorganizados seis anos mais tarde pela mesma autora e da seguinte forma:

i. Auto-aceitação: definida como o aspecto central da saúde mental, tratase de uma característica que revela elevado nível de autoconhecimento, ótimo funcionamento e maturidade. O sentimento de aceitação gera estima, segurança em si e nos outros. Significa uma atitude positiva sobre si mesmo e o seu passado, significa reconhecer e aceitar suas características positivas e negativas, e que emergem como uma das principais características do funcionamento psicológico positivo;

ii. Relacionamento positivo com outras pessoas: descrito como fortes sentimentos de empatia e afeição por todos os seres humanos, capacidade de amar fortemente, manter amizade e identificação com o outro. Ter relações positivas é o mesmo que manter relações afetuosas, satisfatórias e com qualidade, sejam elas familiares, de amizade ou de intimidade;

iii. Autonomia: implica em ser autodeterminado e independente, em fazer escolhas ou tomar decisões de acordo com o que acredita ser melhor, dentro de seus próprios padrões, sem se sentir afetado por pressões sociais, sejam elas em relação à forma de pensar e/ou agir. São seus indicadores o locus interno de avaliação, individuação, regulação interna do comportamento e o uso de padrões internos de autoavaliação, resistência à aculturação e independência acerca de aprovações externas;

iv. Domínio do ambiente: significa a capacidade do indivíduo para criar ambientes adequados às suas características psíquicas, capacidades físicas e às suas competências comportamentais, e usufruir das oportunidades que surgem ao redor. Significa ter competência para 
escolher e manejar contextos apropriados às suas necessidades e valores, ter controle de ambientes complexos, eliminar barreiras e fazer adaptações pessoais ou no ambiente, quando necessárias;

v. Propósito de vida: significa ter metas, manutenção de objetivos, intenções e senso de direção perante a vida, mantendo o sentimento de que a vida tem significado e que existe sentido em sua vida presente e passada, tem crenças que dão propósito à vida e tem motivação para continuar vivendo;

vi. Crescimento pessoal: alto senso de desenvolvimento, necessidade de crescimento contínuo e aprimoramento pessoal, reconhecem seu potencial de realização e estão abertas a novas experiências, vencendo desafios que se apresentam em diferentes fases da vida, e suas mudanças refletem autoeficácia e autoconhecimento (Siqueira \& Padovam, 2008).

Para Fonseca ${ }^{59}$, segundo Silva (2010, p. 16), os estudos acerca do BEP assumem uma importância particular quando aplicado aos idosos, "quer ao impacto do envelhecimento nos aspectos associados ao seu bem-estar, quer à necessidade de preservação de níveis satisfatórios de bem-estar psicológico, enquanto recurso adaptativo ao longo da velhice". Desta maneira, o caráter desenvolvimental do BEP compõe-se como uma abordagem sensível ao processo de envelhecimento, permitindo compreender como os indivíduos, à medida que envelhecem, se tornam agentes ativos de transformações em si próprios e no seu meio, de maneira a garantir a harmonização entre os seus componentes físicos, mentais, emocionais e espirituais.

Anita Liberalesso Neri (2009), numa perspectiva de desenvolvimento ao longo de toda a vida (life span), afirma que as necessidades afetivas dos idosos estão diretamente relacionadas com a prevenção e promoção da saúde, e que estas necessidades não são diferentes daquelas que caracterizam outras fases da vida. A referida autora considera 0 amor, a alegria e 0 domínio/controle/autonomia como sendo algumas das principais necessidades afetivas dos idosos, que relacionadas entre si remetem à questão da

59 Fonseca, A. M. (2006). O Envelhecimento. Uma abordagem psicológica. Lisboa: Universidade Católica Editora. 
subjetividade, tornando-se extremamente relevantes para a sua adaptação, para a manutenção das suas relações sociais, para o seu equilíbrio psicofísico, para a funcionalidade cognitiva e para o seu bem-estar subjetivo. É uma possibilidade de envelhecer bem e ganhar recursos psicológicos para enfrentar as vicissitudes do envelhecimento, a fim de se evitar a tristeza, a apatia, a estagnação e o isolamento social. O que se constata é que os fatores de depressão nesta fase da vida podem ser preceptores de uma velhice insatisfatória, pois nesta fase existe a preocupação com a velhice cronológica, com os decréscimos fisiológicos e com a aproximação da morte.

Neri discute o amor sob suas três formas de manifestação: o amor erótico, a amizade e a comunhão. O amor erótico pode ter um sentido filogenético e uma importância ontogenética. No sentido filogenético o amor está a serviço da continuidade da prole e se manifesta com mais ênfase na fase da juventude e na vida adulta. Quando o amor adquire uma importância ontogenética, a intimidade e o prazer proveniente do contato com o parceiro possibilitam o autorreconhecimento e o crescimento pessoal.

Neste sentido, a intimidade está a serviço do desenvolvimento e da integração da personalidade. O amor erótico associado à intimidade remete ao desenvolvimento do self, o qual beneficia o indivíduo, seu parceiro e a descendência. A intimidade está também a serviço do cuidado, que se traduz no cumprimento de três conjuntos de ações: a de educar e proteger a descendência; a de criar ideias, valores, bens materiais e bens espirituais, e a de oferecer e manter esses elementos. (Neri, 2009, p. 104)

Estes atos encontram a sua máxima expressão na meia-idade e na velhice. $\mathrm{Na}$ meia-idade constituem o desejo de o indivíduo atuar como conselheiro e mentor, já na velhice, uma maior preocupação com o bem-estar da humanidade. Se por um lado, a tarefa de "cuidar do outro" pode causar ônus de natureza psicofísica e social, por outro, pode trazer ganhos afetivos e sociais. Cuidar é um processo de dar e receber, que implica respeito e responsabilidade. O cuidar comporta, entre outras manifestações, a interdependência entre os contemporâneos, os mais velhos e os mais jovens, e 
entre estes e as novas gerações. O bem-estar do idoso está associado também à livre escolha e às amizades de pessoas da mesma geração, nem tanto às relações obrigatórias, como as conjugais e familiares. Para Neri (2009, p. 105) as amizades "são úteis à adaptação se e quando proporciona conforto psicológico, informação sobre si mesmo e confirmação da identidade, da relevância da trajetória individual e dos valores pessoais".

Outra necessidade dos idosos é o convívio, ou seja, a amizade, segunda manifestação do amor. Cultivar amizades nesta fase da vida, principalmente da mesma geração é de suma importância. Ter amigos contribui para a adaptação e para a confirmação da identidade, como também para as informações acerca de si próprio e para a importância do curso individual e dos valores pessoais, além de oferecer garantias de pertencimento a uma rede de relações comuns e mútuas. Como em qualquer idade os idosos necessitam de relações sociais e de companheirismo, necessitam saber que são amados, cuidados e valorizados. As redes sociais, ao longo da vida, auxiliam o indivíduo a encontrar sentido nas suas experiências de desenvolvimento, além de fornecer elementos para o autoconhecimento e ajudar a manter e melhorar a autoestima. Estas redes, adicionalmente, é que garantem aos idosos, em caso de doença e incapacidade, receber apoio afetivo, material e instrumental.

A comunhão, terceira manifestação do amor, é algo que coloca o homem em contato com a transcendência, que dá sentido à existência material. Neri (2009, p. 107) aponta que, "o senso de transcendência pode ser um apoio para lidar com eventos incontroláveis, cuja probabilidade de ocorrência aumenta com o passar dos anos". Quando os idosos são capazes de lidar com os seus sentimentos, cognições e sofrimentos de forma instrumental, eles se mostram menos vulneráveis psicologicamente e estão menos propensos à depressão e à ansiedade.

Já a alegria, está associada à exploração do entorno, do ambiente, do mundo, por meio do lazer e do desfrute das relações sociais. Não é verdade que os idosos não demonstram ter interesse por nada. Idosos de todas as camadas sociais podem ter uma vida rica de sentidos, com objetivos orientados ao self e ao mundo exterior. Quanto maior os afetos positivos, que resultam dessa interação, mais fortalecido se torna o indivíduo idoso, aumentando a sua capacidade de processar recursos psicológicos para enfrentar emoções 
negativas. Quanto maior a complexidade emocional, principalmente em contextos mais seguros e previsíveis, maior a capacidade de conservar emoções positivas em circunstâncias de sofrimento, ansiedade, estresse e o ônus físico e psicológico do cuidado.

A necessidade de domínio/controle/autonomia é de suma importância. Mesmo debilitado, desde que na ausência de dores crônicas, depressão grave ou inatividade física, os idosos podem funcionar bem com as capacidades físicas, psicológicas e sociais a que dispõem. Conforme Neri (2009, p. 108), “as autocrenças sobre capacidade física e cognitiva e a resiliência emocional funcionam como recursos adaptativos relevantes à manutenção do bem-estar subjetivo e da funcionalidade, mesmo na presença de perdas."

Em síntese, Neri considera que "as manifestações do amor ligam-se à alegria, à exploração e ao desfrute; ligam-se ao domínio, à autonomia e à realização, que colaboram para a construção de afetos positivos e contribuem para o senso de autorealização e o senso de autoeficácia” (Neri, 2009, p. 108). Estas relações são de extrema importância para a adaptação do indivíduo idoso, já que ajudam a moderar a influência dos decréscimos físicos e das perdas psicológicas e sociais, que terminam por afetar a funcionalidade física, cognitiva e o bem-estar subjetivo.

Um outro elemento vital da condição humana e também componente do bem-estar é o estado de humor, que na linguagem corrente indica um "estado de espírito", um "estado de ânimo", cuja intensidade representa o grau de disposição emocional e satisfação do indivíduo, e que por estar intrinsecamente enraizado na personalidade provoca a sensação de alívio. Do apático ao eufórico o humor pode sofrer variações de estado em decorrência da relação do sujeito com as circunstâncias externas, como também em relação às suas expectativas, às suas experiências passadas e às pressões exercidas pelo meio, modificando, com tudo isso, o seu modo de percepção acerca das experiências reais, desempenhando, na esfera afetiva, o mesmo papel que a consciência exerce na esfera intelectual, perpassando todo pensamento ou ato intencional. Deste modo, lembranças, percepções, juízos e condutas, produzem sempre uma mudança no estado de humor. De acordo com Organização Pan-americana de Saúde (2012, pp. 28-29) 
O humor é uma função indispensável para a preservação da autonomia do indivíduo, sendo essencial para a realização das atividades de vida diaria. (...) $\mathrm{O}$ espectro dos problemas associados ao rebaixamento do humor ou baixa motivação varia desde a tristeza isolada até a depressão maior. Existe a depressão-sintoma e a depressão-doenca. Os transtornos depressivos podem ser acompanhados de tristeza ou nao. A depressão refere-se a uma síndrome psiquiátrica caracterizada por humor deprimido, perda do interesse ou prazer, alterações do funcionamento biológico, com repercussões importantes na vida do indivíduo e com uma duração de meses a anos. Nao é uma consequência natural do envelhecimento.

De acordo com Neri (2009), exercitar o humor é, de certo modo, convocar a alegria e a felicidade, é diminuir a tensão e o estresse, é contribuir com a manutenção da saúde e do bem-estar psicofísico e social, é facilitar a cura da depressão, da angústia e da falta de autoestima. Segundo a referida autora, se desesperançados, os idosos tendem a apresentar comportamentos de isolamento social, mas se animados e alegres, ao contrário, apresentarão comportamentos de enfrentamento e disposição pela vida.

\section{4- O Centro de Convívio para Idosos do Bonfim (CCIB)}

O Centro de Convívio para Idosos do Bonfim (CCIB), inaugurado em 1989, é uma casa de apoio à população envelhecida residente na Freguesia do Bonfim, na cidade do Porto, em Portugal, que atende em média 60 idosos, entre homens e mulheres. O CCIB divide-se em duas valências: "Centro de Dia" e "Centro de Convívio". Ambas valências consistem numa resposta social e na prestação de um conjunto de serviços que contribuem para a manutenção do bem-estar dos indivíduos idosos no seu meio sócio-familiar. De acordo com o regulamento interno, o CCIB tem como meta:

i. Promover o bem-estar social dos idosos, numa convivência sã e num ambiente saudável, minimizando o efeito dos problemas;

ii. Fomentar as relações interpessoais dos idosos, a fim de evitar o isolamento; 
iii. Melhorar as condições de vida dos idosos para que se sintam física e mentalmente capazes de viverem com certa autonomia e independência;

iv. Proporcionar momentos de lazer por forma à manutenção do bem-estar biopsicosocial;

v. Ajudar o idoso a sentir-se útil e válido no conjunto cultural onde vive;

vi. Estimular o idoso a sentir-se útil na vida social e cultural da comunidade;

vii. Prevenir situações de dependência e promover a autonomia.

Além destes objetivos o CCIB busca assegurar aos seus frequentadores o cumprimento de atividades diversas e a prestação dos seguintes serviços: café da manhã, almoço e lanche da tarde. As atividades desenvolvidas no CCIB vão ao encontro das necessidades, desejos e carências detectadas ao longo do tempo, tais como: convívio; hidroginástica; atélier de trabalhos manuais; jogos pedagógicos; dinâmicas de grupo; atélier de treino de competências; intercâmbio geracional; atélier de teatro; atélier de dança; colônia balnear; passeios e visitas a monumentos e museus; festa de natal e carnaval, entre outras.

\section{5- A fase protocolar}

A fase protocolar constituiu um passo extremamente importante para a implementação do programa Humor e Bem-estar na Velhice. Durante esta fase procedemos a aproximação com a direção do Centro de Convívio para Idosos do Bonfim (CCIB), como também a definição do grupo e de toda a logística necessária para o cumprimento das atividades, como por exemplo: o número limite de participantes; a visualização e adequação do espaço físico (onde, eventualmente, seriam desenvolvidas as atividades); os equipamentos e mobiliários necessários; a calendarização global e semanal do programa (início, término, dia e horário); a definição dos meios de divulgação; a definição do modo de inscrição dos interessados. 


\section{6- A calendarização do programa}

Quadro 5.1: Calendarização global

\begin{tabular}{|l|l|l|l|l|l|l|l|}
\hline \multicolumn{1}{|c|}{ Cronograma } & \multicolumn{5}{c|}{2014} \\
\hline \multicolumn{1}{|c|}{ Etapas } & Mar & Abr & Mai & Jun & Jul & Ago & Set \\
\hline Implementação do programa & & & & & & & \\
\hline Divulgação do programa & & & & & & & \\
\hline Inscrição dos interessados & & & & & & & \\
\hline Entrevista & & & & & & & \\
\hline Execução das atividades & & & & & & & \\
\hline
\end{tabular}

As sessões, que somaram um total de 23 (vinte e três), tiveram uma frequência semanal de 03 (três) horas de atividades, com um intervalo de 15 (quinze) minutos, ocupando todas as terças-feiras do referido período.

\section{7- A implementação do programa}

O programa interventivo Humor e Bem-estar na Velhice teve lugar num espaço cedido pelo Centro de Convívio para ldosos do Bonfim (CCIB), que disponibilizou todo o apoio e toda a logística necessária para a sua execução: uma sala ampla, iluminada e ventilada, com armário, mesa, cadeiras, poltronas e equipamento de som, devidamente apropriada para o cumprimento das atividades e para se garantir a segurança e a comodidade dos idosos.

\section{8- A divulgação do programa}

Para a divulgação do programa Humor e Bem-estar na Velhice contamos com a mediação da direção do Centro de Convívio para Idosos do Bonfim (CCIB), 
que nos possibilitou contactar diretamente os idosos frequentadores do Centro de Dia. Nesta aproximação buscamos deixar claro e compreensível que os interessados em participar do programa não seriam submetidos a determinadas condições, muito menos passariam por um processo seletivo. Qualquer pessoa com idade igual ou superior a 65 anos, independente do gênero, etnia, religião, nível de escolaridade ou classe social, desde que por livre escolha, poderia se inscrever no programa. Demos a entender, também, que os participantes do programa não estariam assumindo qualquer tipo de compromisso com 0 investigador, com o grupo ou com a direção do CCIB, e que teriam total liberdade para se ausentarem ou desistirem do programa em qualquer altura do processo.

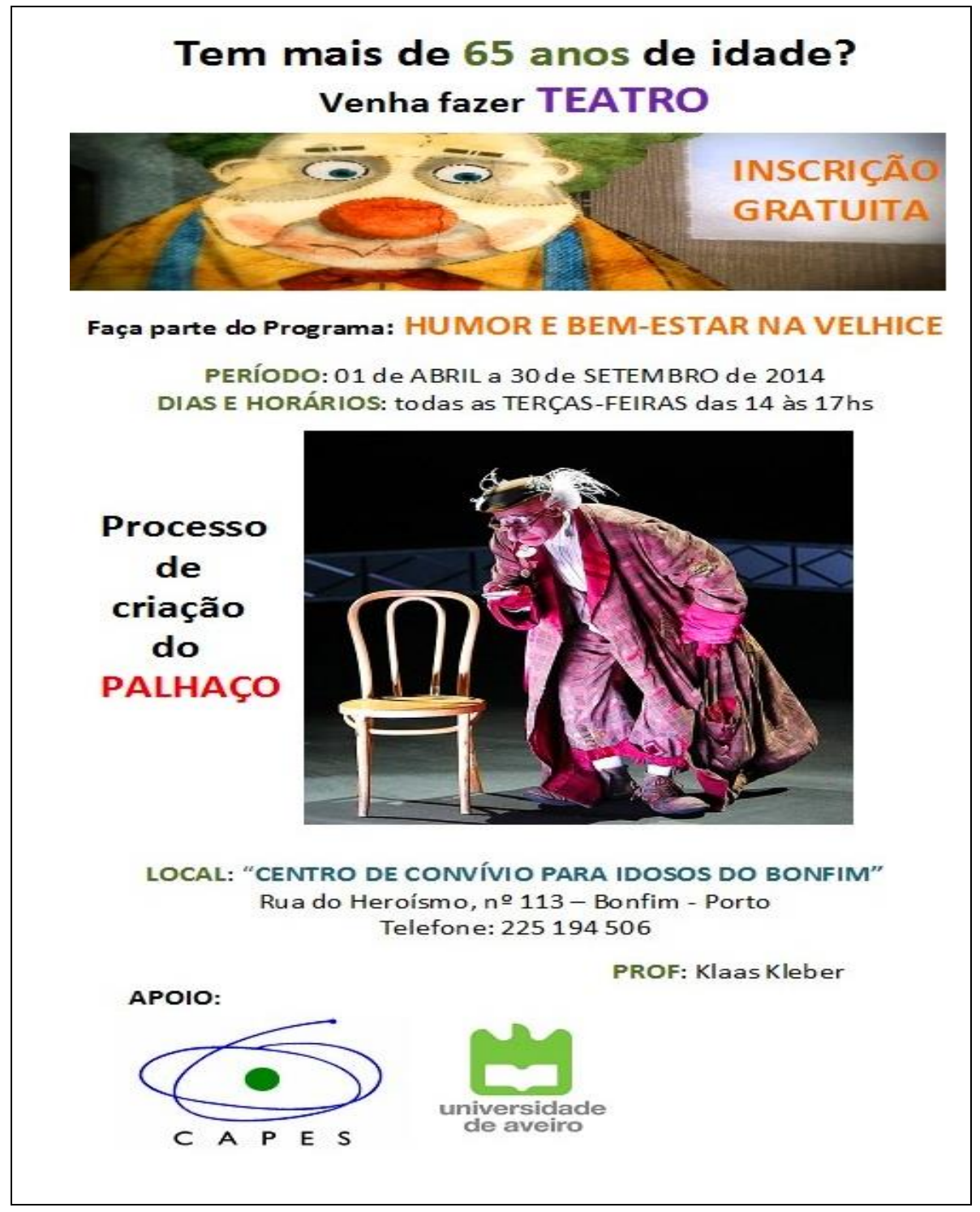

Imagem 04: Cartaz de divulgação do programa 


\section{9- A inscrição dos interessados}

As inscrições para o programa Humor e Bem-estar na Velhice foram realizadas pela direção do Centro de Convívio para Idosos do Bonfim (CCIB). Para tanto, solicitamos aos responsáveis pela efetuação das inscrições que os interessados, desvinculados da perspectiva de obrigatoriedade, decidissem por si só, de forma livre e espontânea, participar ou não do programa. Ou seja, que os idosos não sofressem nenhum tipo de imposição, fosse por parte da direção, dos servidores do CCIB, dos amigos ou da família, haja vista que cada um deles, como qualquer pessoa, tem discernimento e capacidade de escolha e decisão.

\subsection{0- Estratégia operacional: princípios estruturais}

Como estratégia operacional buscamos desenvolver um "Sistema de atividades", constituído por um conjunto de atividades e técnicas corporais (preparação e expressão corporal), jogos tradicionais, jogos teatrais e exercícios clássicos de clown, que são parte ocorrente nos processos de criação do clown. Esta estratégia nos possibilitaria um olhar multifacetado sobre a realidade vivida pelos sujeitos da pesquisa nos contextos observados.

Quadro 5.2: Conteúdo programático

\begin{tabular}{|c|l|}
\hline Atividade & \multicolumn{1}{|c|}{ Ocorrência } \\
\hline Corpo & $\begin{array}{l}\text { Procedimentos de aquecimento, alongamento, massagem } \\
\text { e relaxamento corporal; integração postural (bases de } \\
\text { apoio, colocação do quadril, equilíbrio, transferência de } \\
\text { peso, deslocamento); exercícios de respiração e voz. }\end{array}$ \\
\hline Expressão Corporal & $\begin{array}{l}\text { Conscientização corporal, sob a forma de pequenas } \\
\text { percepções: movimentos do corpo; espaços e planos; ritmo } \\
\text { e tempo; sensações e estados corporais. }\end{array}$ \\
\hline
\end{tabular}




\begin{tabular}{|c|l|}
\hline Atividade & \multicolumn{1}{|c|}{ Ocorrência } \\
\hline Jogos Tradicionais & $\begin{array}{l}\text { Jogos em grupo, com regras, objetivos, desafios que } \\
\text { orientam, incitam e envolvem a ação espontânea dos } \\
\text { jogadores. }\end{array}$ \\
\hline Jogos Teatrais & $\begin{array}{l}\text { Jogos de improvisação (livre ou planejada), acrescidos de } \\
\text { uma estrutura dramática: ONDE, QUEM e O QUE, com } \\
\text { foco no trabalho do clown. }\end{array}$ \\
\hline Exercícios & $\begin{array}{l}\text { Situações; estímulos escatológicos, imagéticos e emotivos; } \\
\text { triangulação; gags; mímica. }\end{array}$ \\
\hline
\end{tabular}

5.10.1 Corpo:

Os trabalhos de corpo (preparação corporal) compreendem um conjunto de atividades compostas por procedimentos de aquecimento, alongamento, massagem e relaxamento corporal, como também um conjunto de técnicas voltadas para o trabalho de integração postural, a partir da percepção de posturas (eixos corporais, postura correta), bases de apoio, equilíbrio, transferência de peso, formas de sentar, levantar, caminhar, parar, etc.

\subsubsection{Expressão Corporal:}

As atividades de expressão corporal compreendem um conjunto de técnicas voltadas para a conscientização do corpo, sob a forma de pequenas percepções, como por exemplo: dos movimentos do corpo; dos movimentos afetivos; de espaços e planos; de ritmo e de tempo; de sensações e estados corporais; colocando sempre em foco a liberação de gestos, de energia e de sentimentos. 


\title{
5.10.3 Jogos Tradicionais:
}

Os jogos tradicionais, além de promoverem a brincadeira e a diversão, estão ligados às possibilidades de interação e comunicação. São jogos em grupo que, como qualquer outra forma de jogo, possuem regras específicas, objetivos, desafios que orientam, incitam e envolvem a ação espontânea do jogador, como também impõem ordem, tensão, incerteza e alegria à ação lúdica.

De acordo com Huizinga (2000, p. 12), todo jogo tem suas regras, "são estas que determinam aquilo que vale dentro do mundo temporário por ele circunscrito. As regras de todos os jogos são absolutas e não permitem discussão".

\begin{abstract}
Qualquer jogo tradicional é realizado a partir de um certo número de regras, aceitas para colocá-lo em movimento. As regras estabelecidas entre os jogadores determinam uma relação de parceria, que implica observação de determinadas leis que asseguram a reciprocidade dos meios empregados para ganhar. Há, portanto, acordo de grupo sobre as regras do jogo e interação, que ocorre a partir da busca de um objetivo comum. (...) A regra estabelece uma estrutura que prefigura o parâmetro para a ação lúdica. (Koudela, 1990, pp. 47-48)
\end{abstract}

Nos jogos tradicionais considera-se que todos os jogadores são "fazedores da ação", ou seja, todos participam do jogo, todos são atuantes. Estes jogos, além de promoverem o descanso, o relaxamento e a diversão, estimulam, aumentam e desenvolvem capacidades, competências e habilidades cognitivas, como por exemplo: a percepção, a atenção, a concentração, a memória e a linguagem.

\subsubsection{Jogos Teatrais:}

Os jogos teatrais são bem mais complexos que os jogos tradicionais e estão ligados a processos de criação e à prática teatral. Estes jogos são uma designação dos jogos improvisacionais, acrescidos de uma estrutura dramática, desenvolvidos pela pedagoga do teatro Viola Spolin, que ao fomentar a ideia da 
possibilidade do teatro fora do palco constrói uma pedagogia baseada na prática e na vivência de jogos, cuja metodologia está fundamentada na experiência, no ambiente da experimentação, na incorporação e na comunicação.

Nos jogos teatrais os jogadores são levados a se inserir na realidade do palco e a se transportar para um mundo completamente distinto do mundo real. $\mathrm{O}$ teatro, segundo Spolin (2005), não é vida corrente, ao contrário, é um mundo distinto da vida comum, um mundo efêmero dentro de um mundo habitual, cuja finalidade ultrapassa a esfera da vida humana. No teatro conferimos ao mundo uma significação diferente da realidade, uma significação de fantasia, pois ele tem uma realidade própria, secundária, ilusória e fictício.

Spolin insere os jogadores nesta realidade fictícia a partir de uma estrutura operacional simples: ONDE (o ambiente de uma cena, lugar onde se passa a ação), QUEM $^{60}$ (o personagem dentro do onde) e O QUÊ (uma ação, uma atividade mútua entre os jogadores). A combinatória destes três eixos (ONDE, QUEM e O QUE), tendo como regra o $\mathrm{FOCO}^{61}$ (meio de se chegar ao objetivo), é que possibilita a experiência das convenções da improvisação teatral e de suas técnicas na forma de vivência de "jogos de teatro", construindo os vários jogos possíveis, com graus de dificuldade e complexidade diversos, além de favorecer a construção de outros jogos similares. Outros dois pontos, também fundamentais neste sistema, são: a INSTRUÇÃO (que permite "guiar" o jogo na direção do foco) e a AVALIAÇÃO (feita pelo grupo).

De acordo com Spolin, um dos princípios estruturantes do jogo teatral é o trabalho de improvisação62. No jogo teatral os jogadores são orientados a improvisar, pois esta é a dinâmica do jogo: estar em jogo sem perder a dimensão

\footnotetext{
${ }^{60}$ No que se refere ao QUEM, foi proposto experienciarmos a máscara do clown.

61 Cada jogo é construído a partir de um FOCO específico, ou ponto de concentração, desenvolvido a partir de instruções e regras. Sua base é a experiência prática e social do grupo e do jogador, onde são "fisicalizadas" as possíveis experiências. Busca-se, assim, desenvolver uma forma de prática teatral que não seja elaborada apenas na mente do jogador, mas por sua vivência improvisacional.

62 A improvisação é uma técnica onde se conjugam diversos princípios da atuação e que constituem o modo de construção e aprendizagem da linguagem teatral. Segundo Costa (2005, p. 39), a improvisação "ancora-se em princípios que atuam como propulsores para o imponderável, o fenômeno imprevisto (que pode ser pré-visto) e, no calor do evento, assume uma natureza inaugural". $\mathrm{O}$ ato de improvisar qualifica o sujeito no que diz respeito à percepção, à ação, à espontaneidade e ao jogo, desenvolvendo nele o sentido de atenção, presença e cumplicidade para responder às eventuais manifestações que sucedem em determinados momentos. Seja como forma de expressão intuitiva, espontânea e livre, ou como recurso de criação, a improvisação é uma abertura que vai também possibilitar ao sujeito a inter-relação com o outro, entenda-se este outro como sendo os colegas de cena, os objetos, o cenário, a música e a plateia.
} 
do momento, o foco no jogo, em si próprio e no outro, nos imprevistos surgidos no ato da cena. Segundo Machado (2005, p. 58), "na improvisação o que está em jogo não é a repetição mecânica da linguagem constituída, mas a dinâmica das relações, dos signos corporais na interação e comunicação entre corpo e ambiente". Estas inter-relações, construídas com o outro no jogo, é que estimulam o jogador em cena, permitindo a ele alargar a sua capacidade de expressão e a ultrapassar os seus próprios limites, como também [re] inventar e [re] significar suas possibilidades de criação, que vão surgindo dos acontecimentos imediatos e da capacidade de resposta do jogador [inter] relacionar-se com o meio à sua volta. Por meio da improvisação os jogadores são levados a experimentar um outro modo de estar e de interagir com o ambiente, a desenvolver a sua potencialidade expressiva e perceptiva, sua capacidade de pergunta e resposta, suas habilidades de jogo e interação.

Outro elemento importante no jogo teatral é a fisicalização, ou seja, a expressão ou manifestação física de atitudes, sentimentos, ideias, impressões e intenções, através do próprio corpo. A fisicalização, mediante Spolin (2005), é o elemento que vai propiciar ao jogador uma experiência pessoal concreta, a partir de processos perceptivos complexos, por meio da sensibilidade, pelo campo do sentir. Em outros termos, trata-se da capacidade de experienciar no ambiente em que esse corpo está manifestando, de penetrar no ambiente e envolver-se total e organicamente com ele, em todos os níveis, principalmente o intuitivo. Segundo a referida autora, o conhecimento intuitivo reage ao imediato, ao aqui e agora, ele vai surgir no momento da espontaneidade, no momento em que o jogador atua com total liberdade, é o momento da descoberta, da experienciação e da criatividade.

A plateia, conforme a autora supracitada, é um outro elemento de fundamental importância no jogo teatral. A plateia, que é constituída pelo próprio grupo de trabalho, deve se tornar uma parte concreta e orgânica do jogo, ou seja, ela deve estar inteiramente envolvida e conectada com o jogo, fazer parte da experiência. $O$ contato direto entre $\mathrm{o}$ jogador e a plateia vai agregar ao seu trabalho de improvisação todos os estímulos e incidentes advindos dela. Este confronto estimula 0 jogador em jogo, colocando-o numa dinâmica de ação $x$ reação. Quando o jogador compreende a plateia e passa a vê-la, não como julgadora, mas como um grupo composto por sujeitos diferenciados, com os quais 
ele está trocando experiência, ele adquire maior confiança em si, maior liberdade e relaxamento no palco. É a partir desta relação (palco x plateia) que o jogador vivencia o "sentir-se exposto", o "ser visto", o "revelar algo íntimo", sem medo e sem sensura.

\subsubsection{Exercícios clássicos de clown:}

Os exercícios clássicos de clown tem como fim habilitar os sujeitos a melhor articular as suas experiências e suas ações espontâneas, como também remetê-los para o território lúdico, fantasioso e encantatório do clown. Da multiplicidade de exercícios selecionamos: estímulos escatológicos, imagéticos e emotivos; triangulação; situações; gags; mímica.

A construção do clown, a saber, também se serve de um arsenal constituído de múltiplas práticas, tais como: acrobacia; malabarismo; pirofagia; perna de pau; mágica; música; dança; entre outras. Todas estas práticas conferem ao clown um acervo técnico/criativo repleto de teatralidade, que pode também servir de alternativa de repertório, enriquecendo ainda mais os seus jogos de cena em qualquer situação de representação. Normalmente tratam-se de habilidades que envolvem resistência física, destreza, amplitude muscular, força, velocidade, rapidez de reação e precisão motora.

\subsection{1- O "Sistema de atividades"}

O nosso "Sistema de atividades" abarcou um conjunto de exercícios de corpo e de expressão corporal, de respiração e de técnica vocal, clássicos de clown, jogos tradicionais e jogos teatrais.

Neste sistema, parte dos exercícios foram recriados por Luís Otávio Burnier e Ricardo Puccetti63, ao longo de assessorias sobre o trabalho do clown. Os jogos teatrais foram extraídos do livro Improvisação para o teatro (2005), de Viola Spolin. Os demais exercícios foram readaptados pelo próprio investigador.

${ }^{63}$ Ambos investigadores do núcleo interdisciplinar de pesquisas teatrais (LUME) da Universidade de Campinas (UNICAMP). 
Todos os exercícios foram devidamente adequados às capacidades físicas, características psíquicas e competências comportamentais dos sujeitos implicados na pesquisa, por se tratar de um grupo de pessoas com idades avançadas e bastante vulneráveis (dado o estado de saúde e a fragilidade física).

Não temos, contudo, a pretensão de sugerir um "manual" a ser seguido, mas sim, que este "Sistema de atividades" possa servir de estímulo criativo e criador, como também de material de consulta, para nortear aqueles que desejarem desenvolver exercícios similares com um grupo de idosos, utilizando e adaptando tudo aquilo que pode ser útil.

Para o bom andamento dos trabalhos apontamos as seguintes advertências:

i. Para que possamos oferecer aos idosos um ambiente de segurança, interação, concentração e de cumplicidade, é necessário que o espaço físico seja devidamente apropriado e preparado para as atividades;

ii. Devemos manter um ambiente de trabalho onde os idosos possam sentirse livres para expressar e para encontrar sua própria natureza criadora, sem imposição ou pressão;

iii. Se o ambiente de trabalho for alegre e livre de autoritarismo os idosos sentir-se-ão mais abertos e dispostos para participarem. A atmosfera deve ser de prazer e relaxamento;

iv. É importante ganharmos a confiança dos idosos, participando junto, levando-os a perceber a importância do outro para o bom andamento dos trabalhos, sem ocultarmos os objetivos dos exercícios;

v. Devemos dar as instruções de forma simples e compreensível. Não devemos apressar os idosos no decorrer dos exercícios. É preciso respeitarmos o tempo, as dificuldades e os limites de cada um;

vi. Os idosos devem ser orientados a interromper ou a abandonar o exercício sempre que necessário, caso sintam tontura, cansaço ou desânimo;

vii. Não devemos exceder nas atividades. Temos que ser flexíveis e alterar o nosso plano de trabalho sempre que for necessário;

viii. Por se tratar de indivíduos com idades avançadas, os procedimentos corporais devem ser leves, graduais e suficientes. Os idosos devem ser orientados a não ultrapassar os seus limites físicos. 
Quadro 5.3: Sistema de atividades

\section{Sistema de atividades}

Corpo e Expressão corporal:

i. Procedimentos de alongamento corporal (da coluna vertebral, dos braços, das pernas, dos pés);

ii. Aquecimento corporal: em círculo. Uma pessoa vai para o centro e produz uma sequência aleatória de movimentos, de forma livre e espontânea, buscando explorar todas as partes do corpo. À medida que os movimentos vão surgindo os demais participantes vão tentando repetir aqueles mesmos movimentos;

iii. Massagem corporal: os participantes põem-se em duas filas, um de frente para o outro. Um massageia o rosto do outro: primeiro com movimentos em cruz, enérgicos, sobre cada sobrancelha, de cada lado do nariz, no queixo, no pescoço e sobre os ombros. Depois, suavemente, com movimentos circulares, nos mesmos locais;

iv. Relaxamento corporal: os participantes estão sentados em suas respectivas cadeiras. Relaxar a coluna vertebral, os ombros, braços e mãos. Relaxar as pernas, os pés. Olhos fechados. Respiração nasal, filtrando o oxigênio. Expirar, soltando o ar pela boca, suavemente. Esvaziar a mente;

v. Integração postural A: Todos de pé/ pés paralelos, na direção dos quadris/ joelhos levemente flexionados/ quadril encaixado/ dividir o peso entre as duas pernas/ coluna vertebral ereta/ corpo empilhado/ abrir o peito/ fechar as costas/ maxilar paralelo à linha do chão/ olhar na linha do horizonte/ ombros relaxados/ braços soltos e relaxados;

vi. Integração postural B: caminhar lentamente/ calcanhar, planta dos pés, dedos/ levantar os pés do chão/ não calcar o chão com os pés/ não deslizar os pés no chão/ coluna ereta/ maxilar paralelo à linha do chão/ transferir o peso de uma para outra perna/ ocupar os espaços vazios/ parar/ ao mudar de direção virar primeiro cabeça, em seguida os ombros, tronco e quadril/ alternar o ritmo/ lento, normal, rápido/ parar/ caminhar;

vii. Energético: em círculo. Imaginar uma bola de energia, conduzir a bola pelo corpo, enviar para o espaço, pegar de volta, enviar para o colega, receber de volta, enviar e receber com diferentes partes do corpo;

viii. Exercício do Espelho: em duplas. De pé os indivíduos $A$ e $B$ se posicionam frente-a-frente. O indivíduo A cria uma sequência de movimentos a partir da relação estabelecida entre o seu corpo e a música proposta, enquanto o indivíduo B (imagem refletida no espelho) tenta reproduzir aquela mesma sequência de movimentos. Ao sinal do orientador invertem a ação;

ix. Encontrar a "fotografia" ou "escultura" de cada sentimento, como por exemplo: alegria, tristeza, ira, pavor, dor, medo, preguiça, etc. Passar de um sentimento para outro, automaticamente. 
Exercícios de respiração e de técnica vocal:

i. Respiração: sentar-se confortavelmente/ manter a coluna ereta/ aproximar o queixo, ligeiramente, do peito/ ombros leves e relaxados/ pés paralelos, separados e apoiados no chão/ braços soltos e relaxados/ colocar as mãos sobre as costelas, de tal forma que as pontas dos dedos não se toquem/ fechar os olhos/ respiração torácica/ inspirar pelo nariz, filtrando o oxigênio/ encher os pulmões de ar/ soltar o ar pela boca, suavemente/ inspirar novamente/ expirar suavemente;

ii. Procedimentos de aquecimento vocal (a critério);

iii. Procedimentos de alongamento vocal (a critério);

iv. Procedimentos de higienização vocal (a critério);

v. Descobrir sons para cada sentimento (alegria, tristeza, raiva, medo, etc.);

vi. Falar em Gramlot (palavras e frases sem significado lógico).

\section{O nariz do clown:}

i. Colocar a máscara do clown (o nariz vermelho), buscar exagerar (fazer crescer, dilatar) ainda mais as expressões faciais. Perceber as mudanças físicas que o uso da máscara provoca.

\section{O olhar do clown:}

i. Explorar o movimento dos olhos (olhar para cima, para baixo, para a direita, para a esquerda, movimento giratório, movimentar as pálpebras, movimentar os músculos da face). Perceber as sensações, expressões e imagens que cada movimento produz;

ii. Buscar um olhar expressivo, vazio, permeável, irritado, vivo, ingênuo, curioso, sonolento, triste, medroso, etc.

\section{Triangulação64:}

i. Duplas de clowns em cena: partilhar sensações e sentimentos, entre eles e com as colegas da plateia (fisicalizar as sensações e os sentimentos);

ii. Duplas de clowns em cena: criar uma sequência de movimentos bem marcados, precisos, claros, limpos (ex: os clowns preparam um jantar).

${ }^{64} \mathrm{O}$ termo triangulação é utilizado no teatro, principalmente na comédia, para determinar o ato de olhar para o público, rompendo então com a denominada "quarta parede" (Kleber, 2012). 
Estímulos para o clown:

i. Escatológicos: vontade de peidar, defecar, urinar, espirrar, tossir, cuspir;

ii. Emotivos: ódio, amor, prazer, dor, tristeza, alegria, medo, choro, timidez;

iii. Imagéticos: andar no deserto, andar na floresta, passear no zoológico, caminhar por uma casa mal-assombrada, andar sobre carvão incandescente.

Situações:

i. Baile de clowns;

ii. Desfile de moda de clowns;

iii. Serenata de clowns;

iv. Brincadeira de clowns;

v. Chá de clowns.

Gags 65 :

i. Uma mosca invisível incomoda o clown durante o espetáculo. Em meio à apresentação o clown improvisa o som de uma mosca, podendo usar a própria voz, um apito ou assovio. Um outro clown tenta matar a mosca, criando uma tremenda confusão. O mais esperto pega uma lata de inseticida aerosol e explica ao outro que, a melhor forma de matar a mosca é usando o inseticida. O outro pega a lata e sai de cena dando "latadas" na mosca invisível e na plateia (como se a mosca estivesse pousada na cabeça, ombros, ou qualquer outra parte do corpo de uma das pessoas da plateia).

\section{Mímica:}

i. Contar um fato trágico através da mímica (exemplo: o clown foi mordido por um cão; o clown pisou numa formiga);

ii. Contar um fato engraçado através da mímica (exemplo: o clown foi espirrar e terminou por soltar um peido);

iii. Contar uma aventura através da mímica (exemplo: o clown foi caçar borboletas; o clown foi pescar).

${ }^{65}$ Pequenas situações cômicas em sequência ou isoladas, geralmente muito breves, que jogam com o elemento surpresa. 
Jogos Tradicionais:

i. Inventar estória: $O$ primeiro jogador inicia uma estória qualquer. Ao sinal do orientador (uma palma) o jogador seguinte dá continuidade à estória, a partir do ponto em que o último jogador parou. Isto deve ser continuado até que o último jogador termine a estória. Terminado o jogo o grupo discute e define um roteiro final (evidenciando os personagens e os lugares onde se passou a estória). São formados pequenos grupos, de acordo com o número de personagens que foram inseridos na estória. Estes grupos irão elaborar uma pequena cena, ensaiar e apresentar;

ii. Um jogador fixa os seus companheiros durante alguns minutos e, depois, de costas, procura descrevê-los com o maior número possível de pormenores: roupas, acessórios, cores, características pessoais, etc;

iii. Atirar Palmas: Todos os jogadores estão de mãos postas. Um deles inicia o jogo enviando uma palma para um jogador qualquer, aleatoriamente (é preciso olhar e apontar a palma na direção do jogador para quem pretende enviá-la). Ao perceber que a palma foi direcionada para ele, o outro jogador fará o mesmo, e assim sucessivamente;

iv. Objetos Imaginários: Um dos jogadores irá criar e manusear um objeto imaginário qualquer (trata-se de um trabalho de mímica: mostrar o tamanho, forma, textura e peso do objeto, dar importância e significado ao objeto). Depois de manusear e utilizar bem o seu objeto o jogador passará a sua vês para o colega do lado, que por sua vez irá criar um novo objeto imaginário, e assim sucessivamente;

v. Jogo da Bola: um jogador cria uma bola imaginária e a arremessa para os outros jogadores. Uma vez começado o jogo o orientador pode sugerir um novo tamanho para a bola;

vi. Propor ritmos: em círculo. Todos os participantes estão de mãos postas. Um deles propõe um ritmo com as mãos (percussivo). O grupo observa atentamente. Em seguida todo o grupo, ao mesmo tempo, repete o ritmo proposto. À medida que a atividade vai progredindo os participantes vão propondo ritmos diferentes;

vii. Jogo do riso: um dos jogadores inicia o jogo dizendo "há" (com a entonação de quem pretende dar uma risada). O segundo jogador diz "háhá", o terceiro "háháhá", e assim sucessivamente. O jogo pode ser repetido por diversas vezes, trocando o "háháhá" por "héhéhé", "híhíhi", "hóhóhó" ou "húhúhú";

viii. Quem é o Maestro: um jogador sai da sala enquanto o grupo escolhe um líder (que será o maestro). O jogador é chamado de volta e colocado no centro do círculo. $O$ jogador vai tentar descobrir quem é o maestro, cuja função é propor movimentos (bater palmas, acenar, movimentar a cabeça, etc.). Todo o grupo imita os movimentos do maestro, buscando evitar que o jogador do centro identifique o líder;

ix. Jogo da Feira: um dos jogadores inicia o jogo com a seguinte frase: fui à feira comprar maçã (ou outra fruta qualquer). $O$ jogador seguinte dá seguimento ao jogo repetindo a mesma fala, só que dessa vez somando uma outra fruta: fui à feira comprar maçã e banana. $\mathrm{O}$ terceiro jogador: fui à feira comprar maçã, banana e melancia. E assim sucessivamente; 
x. Jogo dos Múltiplos: neste jogo utiliza-se uma pequena bola. Podemos começar com os múltiplos de 3 (três): durante a contagem os jogadores não podem dizer os números que são múltiplos de três ou terminados em três (ex: os números $3,6,9,12,13,15$, etc.), no lugar de um destes números o jogador diz BOLA. Exemplo: o primeiro jogador diz 1 (um) e passa a bola para o colega seguinte; o segundo jogador diz 2 (dois) e passa a bola para o colega seguinte; o terceiro jogador diz BOLA (no lugar de dizer o número três) e passa a bola para o colega seguinte, e assim sucessivamente. $O$ jogador que errar na contagem é eliminado do jogo;

xi. Jogo do pato: o jogador A (segurando um pato de borracha) diz para o jogador B: aqui vai o pato (passa o pato para o jogador $B$ ). $O$ jogador $B$ pergunta: $O$ quê? $O$ jogador $A$ responde: $O$ pato. Dando prosseguimento ao jogo, o jogador $B$ passa o pato para o jogador $C$ : aqui vai o pato. $O$ jogador $C$ pergunta: $O$ quê? $O$ jogador $B$ se volta para $O$ jogador $A$ e pergunta novamente: $O$ quê? $O$ jogador $A$ responde: $O$ pato. $O$ jogador $B$ responde para o jogador $\mathrm{C}$ : $\mathrm{O}$ pato. $\mathrm{O}$ jogador $\mathrm{C}$ diz para o jogador $\mathrm{D}$ : aqui vai o pato. $O$ jogador $D$ segura o pato e pergunta: $O$ quê? $O$ jogador $C$ pergunta para $B$ que pergunta para o jogador $A$ : $O$ quê? $O$ jogador $A$ responde novamente: $O$ pato. $\mathrm{O}$ jogador $\mathrm{B}$ dá a mesma resposta para o jogador $\mathrm{C}$, que responde 0 mesmo para o jogador $\mathrm{D}$, e assim sucessivamente (só o primeiro jogador, o A, pode dar a resposta: $O$ pato).

Jogos Teatrais:

i. Um clown entra no picadeiro (palco), dá uma volta e sai;

ii. Um clown entra no picadeiro disfarçando, escondendo e sai;

iii. Um clown entra no picadeiro, demonstra o seu sentimento ou desejo (alegre, triste, raiva, medo, vontade de peidar, espirrar, etc.). Este exercício pode ser feito em duplas, com os parceiros tendo sentimentos opostos, por exemplo: um triste e o outro alegre, um bravo e o outro com vontade de espirrar;

iv. Um clown entra no picadeiro, improvisa uma situação qualquer e sai;

v. Blablação A: dois clowns estão no picadeiro. O primeiro clown conta para o segundo clown um incidente passado, e vice-versa. Exemplo: uma luta entre dois clown (mostra como a luta aconteceu);

vi. Blablação B: o clown deve vender alguma coisa para a plateia, em blablação (o clown deve olhar diretamente para a plateia; a mímica corporal e a sua entonação darão maior intensidade à sua atuação; o clown pode demonstrar como se utiliza o objeto e até mesmo convidar alguém da plateia para testar o produto);

vii. Diálogo cantado: dois clowns devem cantar o diálogo, em lugar de dizê-lo;

viii. Sussurrar-gritar: dois clowns dialogam. Na primeira vez sussurram, na segunda vez (repetindo o mesmo diálogo) falam aos gritos;

ix. O que faço para viver? O clown vai para o picadeiro, deve demonstrar o que ele faz para viver (exemplo: é malabarista, atleta, cozinheiro, etc.);

$\mathrm{x}$. Bonecos: dois clowns contracenam, movimentam-se como marionetes ou bonecos movidos à corda (movimentos claros, limpos e precisos); 
xi. Chamada telefônica: o clown atende uma ligação (não contar para o público quem está do outro lado da linha). O orientador pode indicar, por sorteio, quem está do outro lado da linha e o motivo da ligação (exemplo: um clown ligando para desejar feliz aniversário, uma vizinha fazendo fofoca, etc.);

xii. Criar cena com objetos: o clown escolhe um objeto qualquer (luvas, chapéu, boneco, livro, guarda-chuva, etc.). Ele deve utilizar o objeto, dialogar com ele, cantar para ele, dançar com ele (dançar com o objeto implica também, como por exemplo, dançar para ele ou dançar segundo a forma dele). Criar, a partir da relação com o objeto, uma forma lúdica de movimentação;

xiii. Surdo-mudo: dois clowns se encontram no picadeiro, tentam estabelecer um diálogo, só que um deles é surdo-mudo. Explorar ao máximo a linguagem gestual (exemplo: o clown surdo-mudo vem em busca de socorro, vem pedir uma informação ou contar um incidente, etc.);

xiv. Criar um quadro cênico: construir um pequeno número para testar com a plateia. As duplas de clowns definem o ONDE (lugar onde se passa a ação), o QUEM (personagens que irão improvisar) e O QUE (a ação). Ensaiar e apresentar para a plateia.

\subsection{2- Buscando uma relação de compreensão}

Por se tratar de um grupo de pessoas com idades avançadas e bastante vulneráveis, suscetíveis a dificuldades e limitações corporais, dado o estado de saúde e a fragilidade física, achamos pertinente buscarmos um breve entendimento acerca dos decréscimos na senescência, para que possamos possibilitá-los, a partir desta compreensão, uma maior comodidade e segurança no decorrer das atividades práticas.

De acordo com Bize e Vallier (1985), o envelhecimento biológico, em particular, é um processo cujos efeitos são visíveis. Todo este processo, que engloba a velhice, pode ser entendido como a perda gradual da capacidade de adaptação do corpo, que está associada ao processo de declínio e deterioração biológica que ocorre com a passagem do tempo, ou seja, envelhecer é um processo que coexiste ao longo da vida e que irá atingir os diversos tecidos, certos órgãos e funções do mesmo modo, em momentos diferentes, mediante os indivíduos e muitas vezes de forma particular, dado ao fato de cada um envelhecer de maneira própria. 
Segundo os referidos autores, à medida que o ser humano envelhece é natural que existam mudanças corporais. Os primeiros sinais evidentes de envelhecimento, e únicos sinais exteriores apreciáveis, surgem na pele. As modificações do tecido, provocadas pelas rugas, são particularmente impressionantes. As mudanças no nível de colágeno, a diminuição da tonicidade e da elasticidade provocam o atrofiamento da epiderme, fazendo com que a pele perca a sua leveza, tornando-a mais seca e flácida, pálida e sem brilho, além do surgimento de marcas de pigmentação ou sardas da idade. Quando se é velho as marcas de expressão do rosto não desaparecem tão facilmente como quando se é ainda jovem, a perda da elasticidade justifica as rugas e a queda dos traços fisionômicos. Paralelo a isto os cabelos embranquecem, ficando mais finos e menos abundantes, sendo a queda de cabelos ou calvície típicas dos homens.

No que se refere à estatura, a partir de certa idade a altura começa a diminuir, devido as transformações dos discos que estão entre as vértebras. Essa evolução vai aumentando, substancialmente, a partir dos 70 anos, atingindo primeiramente as mulheres. Simultaneamente as costas tendem a se curvar, acentua-se a curvatura dorsal e os joelhos enfraquecem. Esse processo pode suceder mesmo antes de se atingir os 80 anos de idade, devido ao enfraquecimento muscular, à lesão das articulações e à deterioração do sistema ósseo, resultando na inclinação do dorso para frente.

Quanto aos músculos, o processo de envelhecimento acarreta perturbações de três ordens: atrofia, diminuição do tônus muscular e diminuição da força. As articulações também perdem a força e a mobilidade, tornando-se local de reumatismos crônicos e lesões degenerativas (artrose), que atacam mais frequentemente a articulação dos quadris, joelhos, dedos grandes dos pés e dedos das mãos, espáduas, coluna lombar e cervical. Geralmente as mulheres são mais propensas à artrose que os homens, isto em razão da menopausa e do período imediatamente ulterior. Já a osteoporose (redução de cálcio nos ossos), lesão típica dos ossos envelhecidos, pode provocar frequentes fraturas nas pessoas de mais idade, principalmente do colo do fêmur, podendo ocorrer também deformações no esqueleto. Trata-se de mudanças progressivas do osso numa substância esponjosa ou porosa (descalcificação), de deformações ósseas e da existência de calcificações anormais das artérias circundantes e dos tendões. 
Envelhecer implica a deterioração progressiva e irreversível do aparelho respiratório. O envelhecimento do aparelho respiratório, de um modo geral, pode acarretar consequências como insuficiência ou esclerose pulmonar, enfisema, bronquite crônica, vulnerabilidade às infecções gripais e o surgimento de insuficiência cardíaca nas cavidades direitas do coração. É perceptível a falta de fôlego ao menor esforço, como também a tosse e a necessidade de expectorar. Nesta fase outros fatores tornam-se suscetíveis, como: a regressão da amplitude torácica (as costas parecem diminuir de largura); a diferença entre as dimensões do tórax em inspiração e expiração forçada; a respiração abdominal aumenta de intensidade, evidenciando o jogo dos músculos da região subcostal; a diminuição das três componentes da capacidade vital (ar corrente, ar de reserva, ar complementar); uma diminuição do peso dos lóbulos; uma modificação da tonicidade dos tecidos; uma alteração da pleura, que se torna seca, opaca e despolida. $O$ envelhecimento dos pulmões também justifica uma quantidade de complicações que podem sobrevir ao nível de todos os tecidos do organismo, devido o menor fornecimento de oxigênio.

Já as transformações sensoriais, incluem a deterioração da visão e da audição. Os olhos e os ouvidos são os órgãos que, do ponto de vista funcional, envelhecem mais rapidamente. A qualidade da vista, por exemplo, depende da qualidade do cristalino. $O$ retraimento do cristalino ou a diminuição do seu poder de acomodação é que provoca a presbiopia. Quanto ao estado da retina, a morfologia do fundo do olho começa a se modificar, diminuindo a capacidade de enxergar às escuras e de modo regular. A cor dos olhos tende a mudar, a íris perde o brilho e a pupila retrai-se. O lacrimejar torna-se frequente, dado à falta de permeabilidade do canal lacrimo nasal, à falta de tônus das pálpebras e à irritação crônica das conjuntivas. Em alguns casos, os cílios superiores começam a cair, contribuindo para a diminuição do brilho dos olhos e, noutros casos, acontece o surgimento de hérnias gordurosas debaixo dos olhos. A catarata, também proveniente da diminuição da acuidade visual, é uma doença ocular frequente em pessoas velhas, e que acompanha uma sensação de embaciado ou nevoeiro, pode ser do tipo central ou periférico. No primeiro caso, a visão é melhor à noite, quando a íris se dilata, já no segundo, a visão é melhor durante o dia, à luz solar.

A surdez é frequentemente associada à velhice. O envelhecimento do ouvido começa perto dos 40 anos e a partir daí vai se perdendo a finura auditiva. 
Nos anos decorrentes essa deficiência vai se tornando mais sensível, acentuando-se progressivamente com o avançar do tempo, podendo se tornar um agravante, dado a fatores acidentais, como infecções, intoxicações e traumatismos. Do ponto de vista funcional, a surdez tende a se tornar incomodativa a partir dos 80 anos de idade.

É típico da velhice a diminuição progressiva da capacidade de adaptação do organismo às mudanças do meio ambiente. No que diz respeito à adaptação térmica, dado ao fato da produção interior de calor se reduzir com a idade, as pessoas velhas mostram-se mais vulneráveis ao frio. Se a temperatura interior se mantém constante por toda a vida até a velhice, numa idade mais avançada a atividade dos mecanismos termorreguladores tende a desgastar-se. O cociente respiratório já alterado não corresponde ao necessário para o frio, isto é, não se verifica um aumento da ventilação pulmonar e a produção de calor é insuficiente. A adaptação ao esforço imposta pelo organismo envelhecido, quando a procura de oxigênio aumenta, provoca a falta de fôlego e a fadiga. Qualquer esforço físico violento se faz acompanhar por um ritmo cardíaco acelerado. Quanto mais avançada a velhice tanto maior a "dívida" de oxigênio. Se o esforço for extremamente excessivo pode-se provocar uma autêntica asfixia. Quanto ao envelhecimento do sistema nervoso, a evolução não é menos nítida:

i. A linguagem - Conjugam-se deficiências de diversas ordens: repetição de frases, dada à diminuição da acuidade auditiva e o déficit progressivo da compreensão verbal; a substituição indevida de palavras; o empobrecimento vocabular, tanto oral quanto na escrita; a lentidão na compreensão e na fala; os erros na maneira de exprimir o que se quer fazer ou dizer; a incerteza confusa perante o inabitual; e a dificuldade no cumprimento de ações simultâneas, como por exemplo, falar e despir-se ano mesmo tempo;

ii. Os reflexos - As primeiras manifestações surgem de forma discreta e a partir dos 40 anos, quando certos reflexos cutâneos já são difíceis de detectar. Quando se arranha com um objeto a parede do abdômen, por exemplo, os músculos abdominais praticamente já não reagem;

iii. O equilíbrio - Com a idade há uma maior oscilação, indícios, ainda que leves, de perturbações do equilíbrio em postura vertical; 
iv. A marcha - A andadura torna-se mais lenta e menos segura, sendo necessário, por exemplo, recorrer a corrimãos para ajudar a subir ou descer escadas, ou bengala para apoio durante as caminhadas;

v. A agilidade manual - Os gestos tornam-se cada vez menos precisos, hesitantes e lentos. A manifestação mais evidente é o tremor, que pode manifestar-se de várias formas: tremor de atitude (localizado nos membros superiores); tremor senil (localizado na cabeça); tremor intencional ou de ação (quando se passa do estado de repouso para a ação). Menos ágil e receoso perante algumas tarefas não habituais, 0 velho sente a necessidade de refletir ou pensar, em vez de partir livremente para a execução desta;

vi. O sono - O ritmo do sono modifica-se. As pessoas velhas demonstram uma maior dificuldade em adormecer, além de se verificar, em muitos casos, uma diminuição do sono. Outras perturbações podem contribuir para a alteração do sono, de ordem geral, as dificuldades respiratórias, o ataque cardíaco e a insuficiência renal. Outras perturbações sobressaem das alterações das reações neurovegetativas, pela mudança da fórmula endócrina e pela perturbação dos centros cerebrais que regulam a vigília e o sono.

No que concerne aos aspectos psicológicos, Squire (2005) comenta que os sintomas psíquicos ou emocionais são naturalmente descritos como fazendo parte do processo de envelhecimento. A saúde psicológica dos velhos evoca, muitas vezes, uma imagem negativa, fazendo com que eles não se submetam a ajudas, devido ao medo de serem estigmatizados. Os decréscimos fisiológicos, a má nutrição, as doenças crônicas, a perda da memória e o uso de medicamentos podem acentuar e agravar os problemas psicológicos nos velhos. Envelhecer é estar mais propenso a doenças, algumas de acomodação rápida e outras crônicas e prolongadas. As doenças que se prolongam são degenerativas e implicam a perda de funções e um sofrimento durante um tempo maior, já as de acomodação rápida levam o indivíduo a mudanças bruscas na vida. Ambas demandam diferentes formas de enfrentamento, envolvendo não só aspectos psíquicos, mas também culturais e familiares. A deterioração da visão e da audição, por exemplo, pode contribuir para 0 isolamento social e a perda da 
autoconfiança e, com tudo isso, levar a pessoa velha a cultivar sentimentos de depressão. Por vezes, os sintomas da depressão de um velho, como por exemplo, a perda de interesse, humor deprimido, perda de peso, alterações dos padrões de sono, perda de energia, agitação e pouca concentração, podem ser interpretados erroneamente como sendo uma consequência natural do envelhecimento, e não é. 


\section{CAPÍTULO VI}

\section{O GRUPO REPRESENTATIVO}

\section{1- A entrevista como técnica complementar da pesquisa-ação}

A fim de obtermos informações que não nos seriam possíveis somente através da pesquisa bibliográfica, da observação participante e dos diários de bordo utilizamos, como alternativa às entrevistas semi-estruturadas, a entrevista focalizada, como procedimento associado à pesquisa-ação.

Como já foi mencionado no ítem 4.6 desta tese, nas entrevistas semiestruturadas as questões são geralmente formuladas de modo a permitir que o entrevistado discorra e verbalize. Quando semi-estruturadas, o questionamento normalmente é mais profundo, como também mais subjetivo, permitindo ao investigador obter informações e/ou dados sobre fatos, atitudes, comportamentos, sentimentos, valores, crenças, razões, motivos, etc. Os pontos fortes das entrevistas semi-estruturadas são: a flexibilidade na aplicação; a facilidade de adaptação de protocolo; a viabilização de esclarecimento de respostas; a taxa de respostas elevadas; e o fato de a entrevista poder ser aplicada com pessoas não aptas à leitura e à escrita (Ribeiro, 2008).

Como alternativa às entrevistas semi-estruturadas optamos pela técnica da entrevista focalizada. Segundo Guerra (2006), esta técnica permite ao investigador, a partir de um roteiro de tópicos concernentes à problemática que se vai investigar, a liberdade de fazer as perguntas que forem necessárias, podendo também sondar razões, motivos e dar esclarecimentos, não obedecendo, a rigor, a uma estrutura formal. A entrevista focalizada pode possibilitar até mesmo a inclusão de perguntas não previstas, mais diretas, mais personalizadas, mais flexíveis e espontâneas, o que favorece ainda mais a interrelação entre o entrevistador e o entrevistado.

Mediante Ribeiro (2008, pp. 143-144), numa entrevista a interação de confiabilidade entre o investigador e o entrevistado é muito importante, "sem a afirmação da interação não se desenvolve o diálogo que possibilita ao entrevistado se abrir, ou seja, se 'desnudar' de qualquer tipo de couraça”. Já ao entrevistado, segundo Júnior e Júnior (2011), a ele é permitido dar respostas 
livremente, de forma natural e espontânea, sempre com o esforço do entrevistador, e muitas vezes para levá-lo a reaver o mesmo foco, quando ele começa a desviar-se da entrevista.

Nossa entrevista com os sujeitos inscritos no programa Humor e Bem-estar na Velhice foi guiada por um roteiro de perguntas abertas e bastante simples. Ao formularmos a entrevista buscamos ordenar as questões de maneira a facilitar 0 rápido engajamento dos entrevistados, e de forma a estimular e sustentar o interesse de cada um deles. Nossa pretensão foi a de obtermos informações primárias e relevantes sobre os entrevistados, que nos permitisse:

1. Conhecer valores, sentimentos, pensamentos e atitudes ocultos no comportamento dos entrevistados;

2. Perceber a realidade vivida por cada um dos entrevistados, tanto no campo pessoal como social;

3. Apurar dados que nos possibilitasse garantir a segurança e a comodidade dos entrevistados no decorrer do processo prático, por se tratar de um público-alvo bastante vulnerável e com idades avançadas, suscetíveis a dificuldades e limitações físicas, dado o estado de saúde e a fragilidade física.

As entrevistas foram agendadas previamente pelo investigador e tiveram lugar num espaço cedido pelo Centro de Convívio para Idosos do Bonfim (CCIB), juntamente com a apresentação e assinatura do Termo de Consentimento Livre e Esclarecido (TCLE). Ao introduzirmos a entrevista, que foi individual, buscamos:

1. Criar, já no primeiro contato, uma atmosfera de afeição e simpatia, para que os entrevistados se sentissem livres de qualquer forma de intimidação, coersão ou pressão;

2. Deixar claro e compreensível as pretensões do entrevistador e o porque da entrevista, esclarecendo dúvidas;

3. Reafirmar que os entrevistados não estariam assumindo qualquer tipo de compromisso com o investigador, com o grupo ou com a direção do CCIB, e que teriam total liberdade para se ausentarem ou desistirem do programa em qualquer altura do processo; 
4. Solicitar dos entrevistados autorização para gravarmos a entrevista, esclarecendo a importância da gravação;

5. Requisitar dos entrevistados autorização para fazermos registros fotográficos e para divulgarmos as imagens.

As entrevistas foram conduzidas de forma adequada, ou seja, guiadas por um roteiro bem delineado, com perguntas abertas, simples e claras, e com a intervenção precisa do investigador. Cada entrevista durou em média um tempo de aproximadamente 20 (vinte) minutos.

O processo de documentação das entrevistas compreendeu 02 (duas) etapas: gravação e transcrição, que foram feitas pelo próprio investigador. $\mathrm{O}$ tratamento do material, sem obediência a um método a rigor, compreendeu outras 03 (três) etapas: a primeira consistiu na leitura das entrevistas; a segunda residiu na seleção e recorte das falas dos entrevistados; e a última, na discussão dos textos selecionados, agregando os referenciais teóricos.

As respostas dadas no momento da entrevista nos chegaram sem grande formulação ou reflexão, o que não quer dizer que não estivessem repletas de sentido e de informações. Independente do grau de dificuldade de expressão verbal ou da formulação do pensamento dos entrevistados, as respostas foram dadas de acordo com as questões apontadas, sendo elaboradas como uma síntese de múltiplas vivências, expressando sentimentos, valores, aspirações, interesses, dificuldades, problemas, impressões, modos de relação, formas de ocupação, etc.

A partir daqui buscaremos traçar o perfil dos entrevistados, isto é, dos sujeitos inscritos no programa, apontando os elementos que irão caracterizar o grupo. Buscaremos, também, trazer à tona e discutir questões concernentes aos sujeitos entrevistados, relacionadas com a problemática a ser investigada, com o respaldo teórico e com trechos das falas dos entrevistados.

As questões que serão apontadas e discutidas a seguir tratam do sentimento de satisfação dos entrevistados com relação à vida pessoal, das atividades diárias (instrumentais, recreativas e sociais) praticadas por eles e do entendimento que eles têm acerca do clown (ou palhaço). 


\section{2- Perfil dos participantes do programa Humor e Bem-estar na Velhice}

Apesar de o Centro de Convívio para Idosos do Bonfim (CCIB) ser frequentado por ambos os sexos, masculino e feminino, o programa Humor e Bem-estar na Velhice contou com a participação representativa de 16 (dezesseis) idosas e nenhum idoso, ainda que as inscrições tivessem sido abertas a todos os interessados em geral, independente do sexo, da idade, da etnia, do estado civil, da escolaridade, da religião, do nível sócio-econômico e do grau de dependência. Não obstante, não tivemos a intenção de averiguar as razões pelas quais os homens não se inscreveram no programa, haja vista que o exigido foi que a adesão fosse de livre escolha, isto é, desvinculada da perspectiva de obrigatoriedade. Ou seja, que os idosos decidissem por si só, de forma livre e espontânea, participar ou não do programa, sem sofrerem nenhum tipo de imposição, fosse por parte da direção ou dos servidores do CCIB, dos amigos ou da família, visto que eles, como qualquer pessoa, têm discernimento e capacidade de escolha e decisão.

De acordo com as idosas inscritas no programa, no CCIB os homens geralmente demonstram mais interesse em participar de atividades como jogos de mesa e jogos de tabuleiro: cartas, dominó, quino, dama, ludo, xadrez, etc. Já as mulheres, apesar de também apreciarem estes jogos, normalmente se mostram mais aptas para atividades manuais ou artísticas, tais como: malha, renda, bordado, pintura em tecido, desenho, colagem, canto coral, teatro, dança, etc. Segundo Fonseca (2004), as escolhas que os idosos fazem muitas vezes refletem experiências incorporadas do seu passado profissional ou de hábitos anteriores, adquiridos e desenvolvidos ao longo da vida. Por outro lado, os idosos também tendem a associar a sua idade a determinadas práticas, que termina por afetar nas suas escolhas ou tomadas de decisão, levando-os a não desempenhar certas atividades porque, segundo eles, não são apropriadas para a idade deles.

Nos seus estudos Nunes (2007) aponta que a diferenciação nas escolhas que os homens e as mulheres fazem das suas atividades também está marcada por fatores de construção social e cultural. Esta construção, denominada relações de gênero, diz respeito àquilo que, ao longo do tempo, as sociedades estabeleceram como modelos e normas comportamentais de masculinidade e feminilidade que delas decorrem, e que se repercutem, quer na construção social 
dos modos de ser, quer na organização social das relações dos sexos, quer nos significados atribuídos à realidade social, quer nas escolhas das atividades, inclusive de lazer. Os comportamentos e os papéis geralmente são moldados social e historicamente, e as "relações de gênero", presentes também nas atividades de lazer, sofrem influências sociais e culturais. Conforme Tejera, Sousa e Sampaio (2013), os homens, por exemplo, tendem a práticas de atividades de interesse físico-esportivo, enquanto as mulheres buscam práticas de atividades manuais e artesanais. Os referidos autores comentam que "na maioria das vezes, essas diferenças já começam na infância, com os adultos impondo atividades do tipo competitivas e agressivas para os meninos e atividades delicadas para as meninas" (Tejera et al., 2013, p. 12). Contudo, segundo Cuenca (2009), independente das escolhas que o indivíduo faça, o mais importante é que ele busque sentido naquilo que se propõe e queira fazer.

Os dados apresentados no quadro 6.4 versam sobre o sexo, a faixa etária, o estado civil, a escolaridade e a situação profissional dos participantes do programa Humor e Bem-estar na Velhice. O grupo representativo, o qual vamos nos referir com algum pormenor, tem algo em comum entre eles: todas são mulheres; todas estão vivendo a fase da velhice; todas são frequentadoras do Centro de Convívio para Idosos do Bonfim.

Quadro 6.4: Caracterização do grupo

\begin{tabular}{|c|c|c|c|c|c|c|c|c|c|c|c|c|c|}
\hline \multicolumn{14}{|c|}{ Caracterização do grupo } \\
\hline \multicolumn{2}{|c|}{ Sexo } & \multicolumn{3}{|c|}{ Faixa etária } & \multicolumn{4}{|c|}{ Estado civil } & \multicolumn{3}{|c|}{ Escolaridade } & \multicolumn{2}{|c|}{$\begin{array}{c}\text { Situação } \\
\text { Profissional }\end{array}$} \\
\hline$M$ & $\mathrm{~F}$ & $70 / 79$ & $80 / 89$ & $90 / 99$ & $S$ & C & $\mathrm{v}$ & $\mathrm{D}$ & $1 \% / 4^{\circ}$ & $5 \%$ & $10^{\circ} / 12^{\circ}$ & $\mathrm{R}$ & $A$ \\
\hline & 16 & 9 & 6 & 1 & 1 & - & 14 & 1 & 13 & 1 & 2 & 16 & - \\
\hline
\end{tabular}

Sexo: $M$ (masculino); $F$ (feminino)

Faixa etária: 70 a 79 anos; 80 a 89 anos; 90 a 99 anos

Estado civil: S (solteiro); C (casado); V (viúvo); D (divorciado)

Escolaridade: $1^{\circ}$ ao $4^{\circ}$ ano; $5^{\circ}$ ao $9^{\circ}$ ano; $10^{\circ}$ ao $12^{\circ}$ ano

Situação profissional: R (reformado); A (ativo) 
O referido quadro demonstra uma unanimidade de mulheres (100\%), uma predominância de mulheres com idades entre os 70 e os 79 anos $(56,25 \%)$, uma predominância de mulheres viúvas $(87,50 \%)$, uma predominância de mulheres com escolaridade entre o $1^{\circ}$ e $4^{\circ}$ ano $(81,25 \%)$ e uma unanimidade de mulheres reformadas (100\%). O perfil de maior representatividade é de idosas com menos de 80 anos de idade, com formação básica, viúvas e reformadas.

Quanto ao número de filhos e netos, na ficha sócio-demográfica pudemos verificar que 13 (treze) das participantes possuem entre 01 (um) e 04 (quatro) filhos e 01 (um) e 12 (doze) netos. Somente 07 (sete) possuem bisnetos, cujo número varia de 01 (um) a 10 (dez). Das 16 (dezesseis) idosas inscritas no programa, 02 (duas) vivem com a família e 14 (quatorze) vivem sozinhas e independentes, porém, mantendo sempre uma boa relação com os seus.

\section{3- O sentimento de satisfação com a vida}

De acordo com Joia, Ruiz e Donalisio (2007), satisfação é um estado complexo e de difícil mensuração, por se tratar de um efeito que reflete, em parte, o bem-estar subjetivo individual|6, ou seja, as condições e os motivos que levam os indivíduos a viverem suas experiências pessoais de vida de maneira positiva. Segundo as referidas autoras, a avaliação da satisfação com a vida é um julgamento da própria vida, relacionado a aspectos como a felicidade, o estado de espírito e os afetos, de acordo com critérios próprios, e que muitas vezes depende da comparação entre as circunstâncias de vida do próprio indivíduo com os padrões por ele estabelecidos. Siqueira e Padovam (2008) apontam que esta avaliação quase sempre se dá a partir da aplicação de concepções subjetivas, formadas em pensamentos e sentimentos sobre a própria existência individual, apoiadas nos próprios valores, experiências, emoções e expectativas.

\footnotetext{
66 Segundo Galinha e Ribeiro (2005), o bem-estar subjetivo (BES) é medido a partir das perspectivas e das experiências internas do próprio indivíduo, buscando focar estados de bemestar duradouros, formado por três componentes: a "experiência acumulada de afeto positivo", que referencia a frequência de emoções positivas no sujeito; a "experiência acumulada de afeto negativo", que referencia a frequência de emoções negativas; e a "avaliação da satisfação com a vida global", determinada como uma avaliação cognitiva positiva da vida pessoal como um todo.
} 
Não temos, neste estudo, a pretensão de descrever e analisar todos os fatores associados ao grau de satisfação ou de insatisfação com a vida, ressaltados nas respostas dadas pelas idosas na entrevista. Pretendemos simplesmente apresentar e discutir algumas condições que, segundo elas, afetam, de forma positiva ou negativa, o sentimento de bem-estar e de contentamento com a vida.

Conforme as respostas dadas na entrevista, as idosas consideram a independência, a saúde, o convívio, a frequência ao CCIB e o trabalho voluntariado como condições fundamentais para uma velhice satisfatória e feliz. Já a viuvez, a solidão e o valor da reforma, foram consideradas como algumas das principais causadoras da sensação de descontentamento com a vida pessoal.

Quardo 6.5: Satisfação com a vida na velhice

\begin{tabular}{|c|c|}
\hline \multicolumn{2}{|c|}{ Satisfação com a vida na velhice } \\
\hline Fatores positivos & Fatores negativos \\
\hline Independência & Vaúde \\
Convívio & Solidão \\
Frequência ao CCIB & Valor da reforma \\
Trabalho voluntariado & --- \\
\hline
\end{tabular}

No que diz respeito à independência, ao que pudemos observar na entrevista, o mais importante para as idosas é manter um comportamento próativo diante da vida, é poder cuidar de si próprias, de forma a ultrapassar a letargia e o comportamento estático de quem se esqueceu como protagonizar os próprios dias. Quatro das entrevistadas comentaram que o mais importante nesta fase da vida é a pessoa "estar ativa", "não ficar parada", "não ficar quieta" e "sentir que ainda sabe fazer as coisas". A saúde foi uma outra condição evidenciada na entrevista, e apontada como algo que pode condicionar a independência e a autonomia. Todas as idosas almejam uma vida longa e em boa condição de 
saúde, para poderem continuar independentes, autônomas e ativas em seus lares, para poderem "fazer a vidinha de casa sem pedir a ninguém que as ajude", para poderem "cuidar dos filhos e criar os netos", sem a necessidade de dependerem de outras pessoas que fizessem por elas ou que lhes possibilitassem a própria subsistência, o próprio estar. Observamos na fala das entrevistadas que depender de alguém não é apenas uma realidade desconfortante, é uma realidade impensável. Nenhuma delas quer se tornar dependente, muito menos ser vista como fraca, inútil ou incompetente. Já o convívio, segundo elas, é uma condição primordial e extremamente necessária para se levar uma vida satisfatória e feliz, principalmente o convívio com os membros da família.

De acordo com a Organização Pan-Americana da Saúde (Opas) (2012), na fase da velhice a satisfação com a vida está muitas vezes associada a questões de dependência e autonomia. A independência (capacidade de realizar algo com os próprios meios, de realizar atividades cotidianas sem auxílio, de realizar atividades básicas de vida diária [AVD] de forma independente) ${ }^{67}$ e a autonomia (capacidade individual de gerir a própria vida, de decidir e de comandar as próprias ações, determinando e seguindo as próprias regras), estão intimamente relacionadas ao funcionamento integrado e harmonioso entre a cognição, o humor, a mobilidade e a comunicação.

A Opas (2012) define cognição como sendo a capacidade mental do indivíduo de compreender e resolver os problemas do cotidiano; o humor como a motivação necessária para exercer atividades e/ou participação social68; a

\footnotetext{
67 De acordo com a Opas (2012, p. 12), a gravidade do declínio funcional nas atividades básicas também pode ser classificada como: Semidependência: representa o comprometimento de, pelo menos, uma das funções influenciadas pela cultura e aprendizado (banhar-se e/ou vestir-se e/ou uso do banheiro). Dependência incompleta: apresenta comprometimento de uma das funções vegetativas simples (transferência e/ou continência), além de, obviamente, ser dependente para banhar-se, vestir-se e usar o banheiro. A presença isolada de incontinência urinária não deve ser considerada, pois é uma função e não uma atividade. Dependência completa: apresenta comprometimento de todas as AVD, inclusive para se alimentar. Representa o grau máximo de dependência funcional.

${ }^{68}$ Mediante a Opas (2012, pp. 28-29), o humor é uma função indispensável para a preservação da autonomia do indivíduo, sendo essencial para a realização das atividades de vida diaria. (...) O espectro dos problemas associados ao rebaixamento do humor ou baixa motivação varia desde a tristeza isolada até a depressão maior. Existe a depressão-sintoma e a depressão-doença. Os transtornos depressivos podem ser acompanhados de tristeza ou nao. A depressão refere-se a uma síndrome psiquiátrica caracterizada por humor deprimido, perda do interesse ou prazer, alterações do funcionamento biológico, com repercussões importantes na vida do indivíduo e com uma duração de meses a anos. Não é uma consequência natural do envelhecimento. Está entre as três principais causas de incapacidade no mundo moderno e constitui-se em verdadeira "epidemia silenciosa", cuja importância na morbimortalidade geral se aproxima à observada nas doenças crônico degenerativas.
} 
mobilidade como a capacidade individual de deslocamento e de manipulação do meio onde o indivíduo está inserido; e a comunicação como sendo a capacidade de estabelecer um relacionamento produtivo com o meio, de trocar informações, de manifestar desejos, ideias, impressões e sentimentos. É necessário que estas capacidades sejam estimuladas e desenvolvidas no indivíduo idoso, principalmente por meio de estilos de vida, de hábitos e comportamentos, como por exemplo: atividades físicas regulares, atividades que estimulem 0 funcionamento cognitivo, atividades direcionadas para o lazer e atividades sociais. Em decorrência do envelhecimento populacional global a meta da Organização Mundial da Saúde (OMS) é a de que os indivíduos consigam manter-se autônomos e independentes pelo maior tempo de vida possível.

Conforme a Opas (2012), a capacidade de realizar atividades de vida diária [AVD], de forma independente, contribui de forma efetiva para a autoestima, para a autonomia e para o bem-estar do idoso. Estas atividades, classificadas conforme o grau de complexidade como básicas, instrumentais ou avançadas, são essenciais para a autopreservação e sobrevivência do indivíduo, e referem-se aos cuidados básicos, como: o cuidado com o corpo; transferência; continência; e alimentação. Quanto maior for a complexidade das AVD maior a necessidade do funcionamento dos sistemas funcionais, como a cognição, o humor, a mobilidade e a comunicação.

As atividades banhar-se, vestir-se e uso do banheiro são funções influenciadas pela cultura e aprendizado, portanto, mais complexas. Atividades como transferência, continência e alimentar-se são funções vegetativas simples, portanto, mais difíceis de serem perdidas. Esse caráter hierárquico das tarefas é extremamente útil, capaz de traduzir a gravidade do processo de fragilização do indivíduo. Assim, o declínio funcional inicia-se por tarefas mais complexas, como o banhar-se, e progride hierarquicamente até chegar ao nível de dependência completa, quando o paciente necessita de ajuda até para alimentar-se. (Opas, 2012, p. 12)

No que se refere à saúde, de acordo com a Opas (2012), ela nem sempre é definida como a ausência de doenças, mas também como uma medida da capacidade de realização de aspirações e do prazer resultante dessas 
realizações. A definição de saúde, mediante a OMS, também está relacionada à funcionalidade global do individuo, à sua capacidade de gerir a propria vida, à sua capacidade de cuidar de si mesmo, ao seu bem-estar físico, psíquico e social. Ou seja, o indivíduo é visto como saudável quando se mostra capaz de realizar suas atividades de vida diária sozinho, de alcançar suas expectativas e desejos, de manter-se ativo em seu meio, de assumir uma função social e de desenvolver seus próprios projetos de forma independente, mesmo que seja portador de algum tipo de doença69.

O que se verifica é que na fase da velhice muitos indivíduos passam a ser portadores de disfunções orgânicas ou doenças, mas que nem sempre estão associadas à restrição das atividades ou da participação social. Mesmo sendo portadores de algum tipo de doença os indivíduos podem continuar a desempenhar atividades e papéis sociais. Neri (2009) comenta que os indivíduos, mesmo numa idade avançada e debilitados, desde que na ausência de dores crônicas, depressão grave ou inatividade física, podem funcionar bem com as capacidades físicas, psicológicas e sociais a que dispõem.

Observamos que, em maior ou menor grau, as idosas ainda se mostram independentes para realizar as suas atividades de vida diária (AVD), o que não quer dizer que não tivessem dificuldades ou que não fossem portadoras de condições clínicas, mesmo as mais simples, como por exemplo: hipertensão arterial, insuficiência cardíaca e doenças crônicas incapacitantes, apresentando sintomas álgicos com certa frequência, como alterações no sistema locomotor, dores provenientes da artrite (inflamação das articulações), reumatismo (inflamações nos tendões e ligamentos), lombalgia (dores lombares), dorsalgia (dores na espinha dorsal), etc.

Segundo Dias (2011), é fácil compreender que a dor tem consequências mais graves quando se é idoso, já que as reservas fisiológicas são menores e a capacidade de compensação mais restrita. Com dores o indivíduo idoso perde não só a força e a agilidade, ele sofre também alterações de humor, perda de autoestima, ansiedade, medo, distúrbios do sono e perda de apetite, entre outras coisas, tornando-se mais dependente de cuidados e do apoio de pessoas.

69 Segundo Dias (2011), a doença, se grave, pode comprometer diretamente o bem-estar biopsicossocial do indivíduo, dependendo da sua capacidade de adaptação, levando-o à ansiedade, à perda da autoestima e à insatisfação com a vida. 
Mediante a referida autora, é importante que a pessoa idosa esteja preparada para aceitar as limitações ou agravamentos de certas doenças que podem emergir na velhice. O que não pode acontecer é a pessoa acomodar-se, pois a passividade em relação à doença pode perpetuar ainda mais a dor, o sofrimento $e$ a angústia. Neri (2009) assinala que quando os idosos são capazes de lidar com os seus sofrimentos de forma instrumental, eles se mostram menos vulneráveis psicologicamente e estão menos propensos à depressão e à ansiedade. No que concerne à saúde e às dores 03 (três) idosas expressaram o seguinte:

- A coisa mais importante, mais importante é a saúde. Saúde, paz, bem-estar com a família, com toda a gente, agente sente-se bem. Mas a principal coisa é a saúde, é a saúde, isso é que é o principal. (FC, 80 anos)

- Eu também estava em casa doente, e olha que eu sou a "mais ou menos" aqui. Mas sabe Deus, tenho força de vontade, sabe, ainda faço muita falta, parece que não, mas ainda faço falta. (MS, 82 anos)

- Costumo dizer: nós temos que fazer das nossas dores nossas amigas, que elas vão sempre a toda a vida, e nós temos que viver com elas e, portanto, no mínimo não as menosprezar. (MJ, 70 anos)

O convívio e as amizades também foram apontados como condições primordiais para uma vida satisfatória e feliz, principalmente com os membros da família. De acordo com Ryff (1989), as relações, sejam elas parentais ou não, quando positivas, podem ser descritas como fortes sentimentos de empatia e afeição pelo outro, como a capacidade de amar fortemente e de manter a amizade e identificação com o outro. Conforme a referida autora, manter um relacionamento saudável com outras pessoas é o mesmo que manter relações afetuosas, satisfatórias e com qualidade, seja de familiares ou de amizades.

No que se refere às relações parentais, pudemos observar, nas respostas dadas pelas idosas, que a proximidade e o bom relacionamento com a família, principalmente com os filhos, netos e bisnetos, possibilita a tranquilidade, o bemestar e a segurança. Apesar de viverem sozinhas as idosas sabem que podem contar com o carinho, a atenção, o apoio e os cuidados dos entes queridos diante de qualquer imprevisto ou necessidade. Segundo Moragas (2004), nesta fase da vida as relações parentais constituem o tipo mais importante de cooperação social, seja ela a família de origem, de destino ou ambas. A cooperação familiar, principalmente dos filhos e netos, se manifesta numa diversidade de funções 
voltadas para as necessidades primárias dos idosos, como por exemplo, o apoio emocional, a alimentação, a ajuda econômica, a higiene da moradia e os cuidados da saúde.

Pudemos observar também que a relação de convívio entre as idosas participantes do programa é bastante saudável, como também a relação entre elas e os demais frequentadores do CCIB. Como proferiram as idosas, no CCIB elas trocam favores, partilham experiências, impressões, ideias, sentimentos, emoções, rememoram o passado, falam de assuntos corriqueiros da vida, falam dos filhos e netos, fazem comentários sobre as novelas e os noticiários, trocam receitas, rezam juntas, jogam cartas, dominó, quino, fazem trabalhos manuais, fazem passeios em conjunto e partilham o chá.

Segundo Neri (2009), o convívio é uma necessidade indispensável do idoso. Cultivar amizades nesta fase da vida, mais ainda da mesma geração, contribui de forma efetiva para a adaptação e para a confirmação da sua identidade, como também para as informações acerca si e da importância do curso individual e dos valores pessoais, além de oferecer garantias de pertencimento a uma rede de relações comuns e mútuas. Como em qualquer idade, o idoso necessita de relações e de companheirismo, necessita saber que é amado, cuidado e valorizado. Mais a mais, a redes relacionais ajudam o idoso a encontrar sentido nas suas experiências, além de fornecer elementos para o seu autoconhecimento e melhorar a sua autoestima. Estas redes, adicionalmente, é que lhes asseguram, em caso de doença e incapacidade, receber apoio afetivo, apoio material e instrumental, seja por parte da família ou dos amigos.

De acordo com Baldin e Fortes (2008), manter um relacionamento positivo, afetuoso e com qualidade com outras pessoas, ter com quem falar e a quem confidenciar os sentimentos, pode ajudar o idoso a recuperar o sentido da vida, a viver com mais otimismo a sua nova situação social e a levar uma vida mais equilibrada e feliz. Neri (2009) aponta que quanto maior os afetos positivos que resultam dessa interação, mais fortalecida se torna a pessoa idosa, aumentando a sua capacidade de processar recursos psicológicos para enfrentar emoções negativas. Quanto maior a complexidade emocional, principalmente em contextos mais seguros e previsíveis, maior a capacidade de conservar emoções positivas em circunstâncias de sofrimento, ansiedade, estresse e o ônus físico e psicológico do cuidado. O convívio e as amizades são fontes de suporte que 
muitas vezes suprem a necessidade de interdependência, fortalecendo a autoestima e a autoconfiança, além de propiciarem a afeição, a plenitude e a alegria. Da importância da amizade, do convívio e da relação com os entes queridos, na entrevista 05 (cinco) idosas fizeram o seguinte comentário:

- Eu considero mais importante a amizade. Eu não gosto mesmo de ingratidão, são duas coisas na minha vida que fazem parte, eu não gosto da ingratidão e gosto da amizade. Acho que a amizade é fundamental na vida de uma pessoa. Quando é ela quem lidera, quando é sincera, é fundamental. É a amizade. (...) É o convívio que me dá mais prazer. (MJ, 70 anos)

- Eu acho que o mais importante é o convívio, porque uma pessoa estar em casa, estar a ver televisão e não conviver com as pessoas, acho que é mal, não é. (...) Logo após o meu marido falecer a médica disse-me: olha, não se meta em casa e conviva. (OS, 81 anos)

- Gosto muito de conviver com as pessoas, pronto, sou amiga da minha amiga. (...) Tenho minha filha e minha netinha que são muito meus amigos. Meu genro também, uma pessoa muito boa mesmo comigo. Portanto, sou muito feliz. (EP, 82 anos)

- É assim, uma vida que me dá prazer em viver porque tenho o aconchego da família. Os netos são meus amigos, e os meus bisnetos, e eu vivo feliz. (MM, 88 anos)

- Na medida do possível tô satisfeita. Vivo sozinha, vivo numa casinha, meu filho é muito meu amigo, e vivo feliz a minha maneira. (FC, 80 anos)

Não podemos deixar de apontar que o CCIB contribui, de forma efetiva, para a integração social, para o processo de promoção da autonomia e para a manutenção do bem-estar das idosas, muitas vezes prejudicado, como veremos a seguir, pela viuvez, pelo isolamento e pela depressão. O Centro de Dia, que é uma das valências do CCIB, possibilita aos seus frequentadores um ambiente acolhedor, seguro e agradável, além de uma convivência sã com outras pessoas da mesma geração e em situações sociais muito semelhantes.

De acordo com a Organização Pan-Americana da Saúde (2012), as redes de apoio social são fundamentais para um envelhecimento saudável. É importante que os idosos, principalmente quando vivem sozinhos, sejam motivados a participar de associações de reformados, centros comunitários, centros de dia e organizações de voluntariados. Este engajamento deve ser incentivado pelas políticas públicas voltadas para a velhice, pois favorece a capacidade de socialização e de integração social, considerados importantes fatores de 
manutenção da saúde e bem-estar do idoso. Já é notório na atualidade um maior envolvimento social entre os idosos, principalmente do sexo feminino, com "grupos da terceira idade", que visam principalmente o convívio social, por meio de encontros, bailes, atividades físicas e passeios, com o intuito de evitar que eles permaneçam reclusos em seu lar. Frequentar grupos da terceira idade e casas de apoio a idosos é uma maneira de garantir a sobrevivência, de romper com os paradigmas da sensação de inutilidade, de não se isolar, de não sentir solidão, de manter-se ativo, de sentir-se útil e de viver melhor. O CCIB, por exemplo, é uma dessas casas que consiste numa resposta social e na prestação de um conjunto de serviços e de atividades que contribuem para a manutenção do bem-estar dos idosos, dando espaço para que eles exponham seus talentos, por meio de atividades que vão ao encontro dos seus interesses. Quanto ao CCIB, na entrevista 07 (sete) idosas fizeram o seguinte comentário:

- Foi aqui que eu passei o melhor da minha vida, foi depois que eu vim pra aqui, estou aqui a 16 anos. Foi um dos melhores momentos que eu passei da minha vida, junto das minhas colegas e da minha doutora. (FO, 92 anos)

- Faz de contra que encontrei aqui um apoio grande de família, e aqui é minha segunda casa. (...) De tarde venho pra aqui um bocadinho pra distrair e vou mais satisfeita pra casa. (AS, 75 anos)

- Depois que fiquei viúva e comecei a frequentar este centro, principalmente aqui, já andei noutros. E aqui tenho me sentido mais à vontade, mais desinibida, porque a Dra. Márcia é uma pessoa que nos incentiva a certas coisas. (OS, 81 anos)

- Eu fico aqui entretida nestas horas vagas e, quer dizer, alivia agente um bocadinho. (...) Aqui no centro eu gosto de tudo o que se faça, todas as coisas que se fazem aqui, a gente ri-se um bocado, agente espairece, agente esquece a vida, esquece tudo, e pronto, é aqui que eu gosto de estar. (FC, 80 anos)

- Desde que eu vim aqui para o centro a minha vida alterou um bom pedaço, comecei a vê-la doutra maneira. (...) Quando eu vinha para aqui nem sequer falava com as pessoas, agora falo com toda a gente e gosto muito de aqui estar. (ME, 77 anos)

- Pronto, aqui passo o dia mais ou menos, não é. Que eu até era muito divertida. Pronto, aqui passo mais ou menos. A solidão mais é da porta pra dentro, chegando a casa. (AM, 70 anos)

- Eu tenho sentido mais feliz quando to aqui, agora. Já estou aqui vai fazer sete anos, e nestes sete anos eu levantei um bocadinho, porque estava mesmo embaixo. (MB, 77 anos) 
Outro acontecimento apontado como essencial para a promoção de uma vida mais significativa e satisfatória na velhice é o trabalho voluntariado. De acordo com uma das idosas entrevistadas, o trabalho voluntariado representa não só a concretização de um desejo, mas, acima de tudo, uma ação de humanização e um signo de amor para com o próximo, representando uma fonte de gratificação e de realização pessoal.

- Uma das coisas que eu pensava que gostaria de exercer, o voluntariado, quando tivesse tempo, isso concretizou-se. Costumo dizer, eu estou a dar o tempo que Deus me deu pra mim pra dar aos outros. Dá de graça o que de graça recebestes, esse é o meu lema. E como eu tenho o meu tempo de graça que Deus me deu eu dou aos outros. Essa é a minha filosofia de vida, portanto, me sinto satisfeita. (MJ, 70 anos)

Segundo Tomás (2001 como citado em Ferreira 2006, p. 33), o trabalho voluntariado ajuda o idoso a preencher o vazio pessoal/social promovido pela reforma, "os indivíduos que se dedicam ao voluntariado atribuem um significado positivo à sua ocupação do tempo, não desvalorizam o que fazem, têm atitudes e discursos mais positivos relativamente à atividade". Estes indivíduos muitas vezes assumem o voluntariado como uma profissão eleita, vocacional, ao ponto de referirem-se à esta atividade como trabalho, por verdadeiramente sentirem que ela preenche uma parte do seu tempo e dá sentido à sua vida. Conforme Ferreira (2006), o trabalho voluntariado é uma forma de atividade que possibilita um espaço e uma abertura para que os indivíduos possam realizar ações solidárias, sublimares e prazerosas, fundamentadas no compromisso e na responsabilidade para com o bem-estar do outro. $\mathrm{Na}$ fase da velhice o trabalho voluntariado é uma ação que pode ajudar o indivíduo a se sentir ativo, útil, integrado, além de preencher o vazio pessoal/social provocado pela reforma, atribuindo, deste modo, um significado positivo à sua nova ocupação e um sentido à sua vida.

Como pudemos verificar, as necessidades primárias das idosas estão diretamente relacionadas com a independência, a autonomia, a promoção da saúde e as relações interpessoais, que relacionadas entre si asseguram o seu bem-estar psícofísico e social. Em suma, a independência, a saúde, o envolvimento ativo com a vida pessoal e social, o convívio afetuoso com a família e os amigos são, como pudemos perceber, determinantes para uma velhice bemsucedida e para assegurar uma vida satisfatória, feliz e com qualidade. 
Três causas sobressairam na entrevista como causadoras da sensação de descontentamento com a vida: a viuvez, a solidão e o valor da reforma. Observamos que parte das entrevistadas rememoram o acontecimento da viuvez como algo trágico, atribuindo à perda do cônjuge o sentimento de insatisfação com a vida. Segundo Fonseca (2004), na fase da velhice os indivíduos estão expostos a perdas múltiplas e sucessivas, como a de parentes e amigos, cujos laços afetivos, decorrentes de uma história pessoal de vida partilhada por muitos anos, foram marcados pela vinculação e pela confiança mútua. Estas perdas, principalmente do cônjuge e dos filhos, terminam por provocar uma sobrecarga muito grande de sofrimentos, provocando um sentimento de vazio, de solidão, de amargura e de impotência, que muitas vezes culmina no isolamento.

- Na altura que meu marido faleceu custou muito, foi de repente. Durante dois anos mentalizei que ele tinha ido fazer uma viagem, mas que voltava. Depois, convenci-me que não e, pronto, comecei a viver a minha vida. Só tem uma coisa, em casa, desde que ele faleceu, nunca mais pus o meu prato na mesa, só quando vão lá as minhas netas e meu filho é que eu ponho a mesa pra todos. Nunca mais sentei à mesa sozinha, porque vejo aquele lugar vazio. É a única coisa que eu sinto, sinto a falta daquele vazio. (OS, 81 anos)

- Eu não me sinto muito contente porque o meu marido morreu e eu fiquei sozinha (...). De maneira que é assim, o meu marido morreu, eu fiquei. De certo modo a minha vida parou, quase que nada me dizia nada. (ME, 77 anos)

- Enquanto o meu marido tava vivo, pronto, tava tudo muito bem. Desde que ele faleceu, não. Tenho uma tristeza muito grande, estou muito insatisfeita com a vida. $E$ por isso que ando num psiquiatra. (...) Nada tem sentido pra mim, a vida morreu pra mim. Desde que eu fiquei viúva, nada, nada me interessa, nem televisão, nem nada. (AM, 70 anos)

- Ora bem, eu tive a minha vida muito triste, meu marido sempre foi muito doente e eu acompanhei-o sempre até a última. (...) Eu estou viúva vai fazer três anos. Esta casa fez-me muito bem na altura de eu ficar viúva, muito bem mesmo, porque eu fechei-me em casa só a chorar. (RR, 75 anos)

- Sinto assim, um bocado triste, um bocado desamparada, por falta do meu marido. Quando tinha meu marido me sentia muito apoiada. (...) Ando assim, com depressões, sempre triste, e não vejo a maneira de ficar alegre. Quero-me rir, mas sinto uma angústia, uma tristeza. (...) Adoro meu marido como se ele tivesse ao meu lado, e respeito como se ele tivesse ao meu lado. (...) Faço de conta que ele está vivo, é assim. (AS, 75 anos)

- Fiquei viúva aos 44 anos e meu marido faleceu aos 56, nem contava com aquilo. (MB, 77 anos)

- Sou feliz, graças a Deus sou feliz, pronto, levou-me meu marido mas mesmo assim continua, a vida continua e, pronto. (EP, 82 anos) 
Pudemos observar na fala das entrevistadas que cada uma delas vivencia a situação da viuvez de uma forma diferenciada e em níveis bem diferentes. Se para algumas a morte do cônjuge representou uma tragédia, cuja dor da separação é difícil de superar, para outras o tempo parece ter tornado um aliado no alívio do sofrimento gerado pela ruptura de um convívio duradouro e amoroso, o que não quer dizer que a situação da viuvez não deixasse de abrigar um estado de desconsolação e tristeza. Nos seus estudos Both et al. (2012, p. 70) aponta que:

O enorme impacto da viuvez na vida das pessoas não se deve apenas à tristeza da ausência, à estranheza na mudança do status social ou ao choque de realidade pela alteração das condições econômicas. Alia-se a isso tudo a dor de perder um grande amor ou, no mínimo, o companheiro de uma vida, o implacável confronto com o fim da existência terrena, enfrentando, simultaneamente, algumas das condições existenciais mais difíceis de elaboração para o ser humano: a impotência, a solidão e a finitude da vida.

Mediante a autora supracitada, a intensidade dos sentimentos negativos relacionados à viuvez dependerá não só do nível do que representou a relação conjugal, mas também das características individuais da personalidade do enlutado e do apoio recebido por parte da família, dos amigos e da sociedade.

Kovács (2009) comenta que ter pessoas a quem falar e a quem confidenciar os sentimentos constitui um apoio para a superação das formas mais comuns de perda. Os familiares, amigos e a comunidade são importantes redes de apoio e proteção para os idosos enlutados. Estas redes são fundamentais e circunstanciais para o enfrentamento adequado da situação de viuvez, já que contribuem para a preservação da dignidade da pessoa enlutada, além de assegurar a ela a manutenção do seu papel existencial. Conforme Both et al. (2012), estas redes possibilitam o amparo emocional, a interação social, o sentimento de pertencimento e o reconhecimento, como também auxiliam na percepção das próprias ações, competências e habilidades. Estas redes é que suscitam um suporte social que configura laços de correspondência e atende à motivação gregária do ser humano. 
Outro fator evidenciado na entrevista foi a solidão, percebida pelas idosas como uma das principais causadoras da insatisfação e do descontentamento com a vida pessoal. No que se refere ao sentimento de solidão, ao analisarmos as falas das idosas pudemos observar que este sentimento está associado, principalmente, ao vazio produzido pela fatalidade marcada pela viuvez e pela ausência dos filhos. O sentimento de solidão também se deve ao fato de as idosas viverem sozinhas, fosse pelas circunstâncias da vida ou pela opção de ficarem só. Sobre o sentimento de solidão, na entrevista 05 (cinco) idosas falaram o seguinte:

- Gosto desses momentos que não estou assim, sozinha, porque não gosto da solidão, porque triste ando eu. (AS, 75 anos)

- Mesmo que esteja sozinha procuro ir ter ao café, que sempre encontro amigos e ali estou a conversar, porque eu não gosto de estar só em casa, não, não gosto, gosto de conviver com pessoas e lidar com pessoas. (EP, 82 anos)

- À noite a chegar a casa custa muito, ainda está a custar muito, parece que cada vez está a ficar pior. (RR, 75 anos)

- É assim, uma vida que me dá prazer em viver. (...) É uma felicidade relativa, porque estou só em casa. (MM, 88 anos)

- Desde que chego a casa a minha solidão torna a vir. A solidão mais é da porta pra dentro, chegando a casa. (AM, 70 anos)

De acordo com Grunewald (2006), na fase da velhice os papéis familiares vão desaparecendo à medida que um dos cônjuges falece ou que os filhos saem de casa. Quando isto acontece o papel de esposo ou esposa, de pai ou mãe, vai deixando de existir, culminando com a "síndrome do ninho vazio". Conforme o referido autor, "psicologicamente ocorre uma 'diminuição do eu', necessitando a reformulação de valores para reestruturar sua auto-imagem, auto-estima, seu reconhecimento enquanto Ser" (Grunewald, 2006, p. 36). A viuvez e o afastamento dos filhos terminam por gerar no idoso um sentimento de solidão, de vazio interior, de angústia, que pode finalizar em isolamento.

Verificamos que das 16 (dezesseis) entrevistadas 14 (quatorze) vivem sozinhas em suas casas. Segundo Neri (2009), estar só em casa, principalmente no período da noite, sem ter muito o que fazer ou com quem conversar, pode fazer com que o sentimento de solidão seja ainda maior e mais sofreguidor, 
gerando um estado de ansiedade e de depressão. Mediante a referida autora, os idosos se tornam ainda mais vulneráveis quando experimentam a solidão. Nesta fase da vida as relações são bastante restritas e, na maioria das vezes, simplificadas. E como em qualquer fase da vida o indivíduo idoso também necessita de relações sociais e de companheirismo, principalmente da mesma geração. Necessita saber que é amado, cuidado e valorizado, necessita sentir que no mundo existem outras pessoas que compreendem o seu vazio afetivo e existencial.

Outra causa desfavorável à satisfação com a vida, ao que pudemos observar, é a dependência das idosas de um mísero benefício, cujo valor não é suficiente para a manutenção da sua subsistência, da sua integridade e do seu bem-estar. De acordo com Fonseca (2004), é lamentável que os indivíduos, nesta altura da vida, depois de perderem o reconhecimento social adquirido após anos de trabalho, terem a sua renda diminuída. Uma reforma com um rendimento baixo pode ter um efeito prejudicial não só no estilo de vida, mas também na saúde do idoso. Não é de se estranhar que a maioria dos idosos se mostrem insatisfeitos e preocupados com a sua condição pessoal, já que vivem com base num rendimento reduzido.

Segundo Anne Squire (2005, p. 14) "o dinheiro tem uma importância vital num envelhecimento bem-sucedido, uma vez que mantém a independência e a autonomia, permitindo às pessoas idosas o acesso a um padrão de vida aceitável". A privação mais grave ocorre ainda com aqueles que vivem sozinhos e dependentes de um mísero benefício, cujos valores não são suficientes para a manutenção da sua integridade, afetando, de forma significativa, na sua saúde, no seu bem-estar e no seu estilo de vida. Receber outros benefícios ou ter outros recursos financeiros, além da pensão estatal, aufere um rendimento regular que possibilita aos idosos não só uma vida com mais segurança, mas também gozar de férias, de passa-tempos e de outros interesses pessoais.

De acordo com Cuenca (2009) e Fonseca (2004), se a velhice for percebida como mais uma etapa do desenvolvimento humano, como um recomeçar, como um tempo que pode ser bem desfrutado, vivido com independência, autonomia e de forma bem criativa, os indivíduos sentir-se-ão incentivados a percorrer novos caminhos e a buscar novos horizontes, novos objetivos, novos desafios, novos interesses e novas experiências que possam 
conferir sentido à sua existência, ainda que, para tanto, fosse necessário fazer uma revisão de valores e uma mudança de hábitos, de comportamentos, de atitudes e de práticas, com o intuito de aumentar a capacidade de viver bem e feliz. O que não pode acontecer é o indivíduo, nesta fase da vida, carregar consigo o fardo de uma vida atrelada à dependência, à doença, à solidão, ao luto, ao sentimento de vazio, de perda, de insatisfação e à ausência de sentido.

\section{4- As ocupações diárias: instrumentais e recreativas}

De acordo com as respostas dadas na entrevista, no decorrer da vida as idosas não se dedicaram a outra coisa senão ao trabalho ${ }^{70}$, à criação dos filhos e às tarefas voltadas para os cuidados com o domicílio, que já lhes tomavam todo o tempo. Todas elas, ao que pudemos perceber, levaram uma vida árdua, cheia de privações, e mesmo hoje passam por inúmeras dificuldades, inclusive de ordem financeira, dado ao valor da reforma, que é excessivamente pequeno.

Ao que pudemos observar, com o afastamento da atividade profissional (que vinha sendo executada regularmente durante anos), com a perda do cônjuge e com a partida dos filhos ${ }^{71}$, somado o surgimento de dificuldades e doenças difíceis de superar, as idosas passaram a viver mais tempo em suas casas e a se ocupar, quase que unicamente, com tarefas intradomiciliares, como por exemplo: fazer compras, preparo de alimentos, limpeza doméstica, lavar e passar roupa, etc. Conforme as idosas, muitas destas tarefas, consideradas comuns e de fácil execução, com o passar do tempo foram se tornando cada vez mais difíceis de serem realizadas, em razão da diminuição do vigor físico, ou seja, da redução do controle postural, da falta de flexibilidade, da diminuição dos reflexos, da lentidão dos movimentos e da dificuldade de locomoção, que se constituem como alguns dos fatores que mais se evidenciam com o aumento da idade

No que diz respeito à atividade profissional, segundo Fonseca (2004), é algo que proporciona aos indivíduos uma oportunidade para a ocupação do dia-a-

\footnotetext{
70 Todas as idosas exerceram uma atividade trabalhista no decorrer da vida. Algumas foram funcionárias públicas, enquanto outras atuaram como empregadas domésticas, agricultoras, feirantes, balconistas, operárias, costureiras, etc.

${ }^{71}$ Conforme Grunewald (2006, p. 36), nesta última fase da vida os papéis sócio-familiares também vão desaparecendo à medida que os filhos crescem e vão embora de casa; seu papel de pai (ou mãe) vai deixando de existir, culminando com a "Síndrome do Ninho Vazio".
} 
dia, como também os integra nas redes sociais, contribuindo para a definição de uma identidade pessoal e atribuindo um sentido social relacionado com a ocupação que desempenham.

Tal como na vida familiar, a vida profissional pode incorporar múltiplos tipos e variedades (manual versus intelectual, de natureza pública versus privada, etc.), devendo a relação das pessoas com a profissão ser vista como uma relação complexa, que gira principalmente em torno do significado que o trabalho adquire para cada indivíduo (forma de ganhar a vida, forma de ser útil à sociedade, meio de promoção social, etc.). Para além disso, trabalhar não é apenas uma questão de realização de tarefas, implica também oportunidades de relacionamento social e de preservação de uma imagem pessoal de competência, não podendo a compreensão dos mecanismos psicológicos implicados na "passagem à reforma" desligar-se destas realidades. (Fonseca, 2004, p. 363)

Mediante o referido autor, se para alguns indivíduos a reforma é percebida como um momento de libertação e renovação, no sentido de se estabelecer novas metas, de fugir da rotina casa/trabalho/casa, de investir na formação e no lazer, além de constituir um tempo precioso e recompensador do qual se pode gozar os frutos de toda uma vida dedicada ao trabalho e apreciar novas atividades e práticas, para outros, ao contrário, a passagem para a reforma não é encarada com positividade, mas sim como a entrada numa fase de sofrimentos, marcada pela ausência de sentido, pelo luto, pelas perdas funcionais, pelas doenças e pelo sentimento de vazio e incompletude. Contudo, independente dos sentimentos relacionados à reforma, se positivos ou negativos, o que se constata é que ela vem acompanhada de receios sobre o que se passará nos anos seguintes, de medos e temores ligados ao pressentimento de inutilidade, de sentir-se deslocado, de dificuldades financeiras e de isolamento, contribuindo para que a ansiedade se instale.

A passagem para a reforma quase sempre é interpretada como um momento de confronto, suscetível a mudanças de percepções, de expectativas, de objetivos e, por conseguinte, da própria identidade, que são implicações mais vastas do que simplesmente $\mathrm{o}$ afastamento da vida profissional. $\mathrm{O}$ mesmo autor sublinha que durante a reforma as novas ocupações devem ganhar um papel de 
relevo no cotidiano do indivíduo, visto que permanecer ativo é uma das condições primordiais para se viver bem e com sucesso a velhice. Segundo ele, se a atividade profissional, até então, foi fundamental ao longo da vida, a partir da reforma outras atividades deverão assumir o meio e o fim para continuar a manter o indivíduo ativo, vivo, independente, autônomo e socialmente integrado.

No que se refere às atividades domiciliares recreativas - percebidas aqui como aquelas ocupações não obrigatórias, das quais se pode dispor livremente, voltadas para 0 entretenimento e para 0 descanso, dirigidas para 0 desenvolvimento de informações e da capacidade criadora, as quais se pode entregar de bom grado e que trazem uma condição de felicidade - observamos nas respostas dadas na entrevista que em suas casas as idosas se ocupam com programações televisivas (novelas e noticiários), trabalhos manuais (costura, renda, malha e confecção de bijuterias), música, leitura e plantas. Conforme Silva (2009), depois da reforma é necessário o indivíduo reinventar novos interesses e novas formas de ocupação. Na velhice, segundo Cuenca (2009), é essencial que o indivíduo busque novos caminhos, objetivos, desafios, alternativas e sentido naquilo que se propõe e queira fazer. O que não pode acontecer é o indivíduo, para além das atividades instrumentais, ocupar o seu tempo com atividades que não Ihe são significativas, muito menos com programações televisivas, se colocando numa atitude passiva durante horas frente a um aparelho de televisão. Sobre suas ocupações domiciliares as idosas responderam o seguinte:

- Entretenho a ver televisão e a fazer qualquer coisa que é preciso fazer durante a semana. (...) Depois de ir almoçar, gosto muito que dá umas variedades toda a tarde na televisão, cantarem, e eu as vezes até me ponho a dançar com os que estão na televisão a cantar. Gosto muito de dançar. E faço uns trabalhinhos que preciso de fazer, de renda e assim. (MC, 70 anos)

- Eu sento-me no sofá, do sofá pra cama, e é assim que levo a minha vida desde que chego a casa. Depois tomo pastilhas pra dormir e, outro dia, outro dia. Não, não faço nada, nada. (AM, 70 anos)

- Gosto muito do meu cantinho, gosto muito das minhas arrumações, gosto de ter a minha casa como deve ser. Tenho um canarinho e, se pudesse, também tinha animais, que eu tive um cãozinho e tudo isso, gosto de bicharada, flores, é o meu gosto de tudo isso, portanto, eu procuro sempre poder arranjar a minha vida assim, com essas coisas todas. (EP, 82 anos) 
- Entretenho-me com as novelas brasileiras, também gosto das portuguesas, mas admiro muito os brasileiros, também tenho pessoas de família no Brasil e assisto telenovelas até uma hora da noite. (AS, 75 anos)

- À noite não faço nada, vejo televisão, já vejo mal das vistas. Antigamente sempre tinha coisas pra fazer e cozer, costura, qualquer coisa, agora parece que já me custa fazer isso, que vejo mal. E chego a casa, ou tenho uma roupinha pra lavar, mas eu limpo o pó, faço assim qualquer coisita. (FC, 80 anos)

- Faço sempre qualquer coisa pra os netos e coisa assim, trabalhos manuais. Este inverno quiseram cachecóis e eu fiz sei lá quantos cachecóis pra os netos, pra minha nora, pra minha neta que casou com meu neto. Eu fiz muita, muita renda, muita. (...) É só isso, ou então estar sentada a ver televisão. (MB, 77 anos)

- Faço bijuterias, ocupo-me muito nisso. Mas também estou a fazer uma coisa muito mal, estou a desmazelar a casa, que minha casa é muito grande e, pronto, baixar-me eu não posso, a limpeza que eu tinha sempre ta posta um bocadinho de lado. (RR, 75 anos)

- Tenho sempre música, sempre música, eu não gosto muito de televisão, não gosto. Só quando há alguma coisa que me diz as notícias, que eu gosto de ficar informada, e pouco mais, de resto, é música, gosto muito de música. (MJ, 70 anos)

- Gosto muito de fazer renda, gosto muito de fazer malha, mas agora, com a coluna, não posso, mas pronto, vez enquando faço qualquer coisa, e faço a minha vida de casa normal. Agora uma coisa que me levava uma hora leva-me duas, porque faço direito e, pronto, ando assim. Vou às compras, vejo televisão, gosto muito de ver as telenovelas brasileiras, e passo assim o tempo. (OS, 81 anos)

- Faço colchas de malha e ponho, depois tiro as que estão daquele lado e ponho pra aquele, eu ando sempre a mexer dum lado pro outro. Depois vou pra o quintal, pro terreno e tiro ervas, eu gosto muito de mexer na terra, gosto de substituir vasos. Não sou pessoa de cruzar os braços e esperar que venha a morte, eu vou mexendo sempre, enquando puder. (MM, 88 anos)

- Na cama é que eu estou bem, aqui sou obrigada ta sempre assentada, mas vou daqui já cansada, porque agente sabe que sentar também cansa. E chego a casa, descanso um bocadito e depois vou fazer alguma coisa. (...) Eu só vejo a televisão, estou deitada e vejo a televisão. (MS, 82 anos)

- Vejo a televisão... e a noite quero falar com Deus, é isso que eu quero. Falar com algum vizinho, dar algum concelho ou uma coisa qualquer, eu gosto de fazer é isso. (FO, 92 anos)

- Vou fazendo umas coisinhas assim mais leves, porque é como digo, não posso baixar muito, não posso fazer certas coisas, estou proibida pelo médico, mas nunca estou parada, estou a fazer uma coisa, a fazer outra, gosto de arrumar as minhas coisas e assim, preencho assim. Às vezes vejo um bocadinho de televisão ou gosto também de vir pro quintal a jardinar, é essas coisinhas pequeninas, coisas que eu possa fazer. (LV, 77 anos) 
- Quase sempre nada. (...) Não apetece assim muita coisa, que agente está desanimada da vida. (...) Faço renda, é o que eu sei fazer, é renda. Faço malha, é o que eu sei fazer. (BP, 71 anos)

- Eu perco muito tempo no computador, nos jogos só. Não tenho internet, não falo com outras pessoas. Estou muito tempo no computador, acho até que estou um bocado viciada nos jogos. (ME, 77 anos)

De acordo com Fonseca (2004), a maioria das atividades recreativas praticadas pelos idosos em seus domicílios são individualizadas, e muitas vezes refletem experiências incorporadas do passado profissional ou de hábitos anteriores adquiridos e desenvolvidos ao longo da vida. Por outro lado, os idosos também tendem a associar a sua idade a determinadas práticas, que terminam por afetar nas suas escolhas ou tomadas de decisão. Segundo Nunes (2007), a diferenciação nas escolhas que os homens e mulheres fazem das suas atividades também está marcada por fatores de construção social e cultural. Esta construção diz respeito àquilo que, ao longo do tempo, as sociedades estabeleceram como modelos e normas comportamentais de masculinidade e feminilidade que delas decorrem e que se repercute, quer na construção social dos modos de ser, quer na organização social das relações, quer nos significados atribuídos à realidade social, quer nas escolhas das atividades, inclusive de lazer. Conforme Tejera, Sousa e Sampaio (2013), na juventude os homens tendem, por exemplo, a práticas de atividades de interesse físico-esportivo, enquanto as mulheres desenvolvem atividades manuais e artesanais. Os referidos autores comentam que "na maioria das vezes, essas diferenças já começam na infância, com os adultos impondo atividades do tipo competitivas e agressivas para os meninos e atividades delicadas para as meninas" (Tejera et al., 2013, p. 12). Ao que pudemos verificar, no decorrer da juventude as idosas aprenderam a costurar, fazer malha e renda, entre outras coisas, e hoje se ocupam com estas mesmas atividades.

No quadro 6.6 apontamos as principais atividades domiciliares, tanto instrumentais como recreativas, desenvolvidas pelas idosas no seu dia-a-dia. 
Quardo 6.6: Atividades domiciliares

\begin{tabular}{|c|c|}
\hline \multicolumn{2}{|c|}{ Ocupações diárias relacionadas ao domicílio } \\
\hline Atividades instrumentais & Atividades recreativas \\
\hline $\begin{array}{c}\text { Fazer compras } \\
\text { Preparo de alimentos } \\
\text { Limpeza doméstica } \\
\text { Lavar e passar roupa } \\
---\end{array}$ & $\begin{array}{c}\text { Televisão (novelas e noticiários) } \\
\text { Trabalhos manuais (costura, } \\
\text { renda, malha e bijuteria) } \\
\text { Música } \\
\text { Leitura } \\
\text { Plantas }\end{array}$ \\
\hline
\end{tabular}

De acordo com as respostas dadas na entrevista, as únicas atividades desenvolvidas pelas idosas na comunidade onde vivem, relacionadas à integração social são: missas dominicais, procissão, festas religiosas e passeios. Já no Centro de Dia, as idosas desempenham outras atividades, como por exemplo: trabalhos manuais (renda, malha, pintura em tecido, artesanato); jogos de mesa (cartas, dominó, quino); teatro (atividade casual); dança (atividade casual); canto coral (atividade casual); decoração para festas (páscoa, São João, natal, carnaval, etc.); hidroginástica e passeios (esporádicos).

- Eu gosto muito de trabalhar nesses trabalhos manuais. Eu gostava muito também de pintar. E vem a páscoa, agente faz uns ovinhos de páscoa, e vem o natal, fazemos outra coisa, e vai-se fazendo assim, umas coisinhas. Gosto de participar nisso. (AS, 75 anos)

- Fazemos aqui as vezes teatro. Dança não, nunca me puxou e não sei dançar, mas gostava de saber, mas não sei dançar. (MB, 77 anos)

- E quando é no carnaval também fazemos as fantasias, e vestimo-nos, e pintamos, e vamos todas pra o baile, pra junta. Faz-se lá no salão da junta uma brincadeira. Isso eu alinho em tudo, tudo o que se passa aqui eu nunca fico quieta, porque eu acho que se estão aqui a olhar por nós gostam também que agente colabore, não é. (MM, 88 anos)

- Gosto muito de estar aqui e de ajudar no que eu posso, e fazer trabalhos de labores, de costuras, de fazer os vestidos de carnaval, quando é preciso. Enfeitar as janelas e as salas, quando é primavera e pra o verão. Gosto muito dessas coisas. (MC, 70 anos) 
- Gosto de tudo, de artesanato, essas coisas que agente aqui faz, gosto de ouvir música portuguesa, gosto muito de ouvir música e, pronto, literatura, dizer poemas, conversar, de rir, assim, essas coisas todas. (FC, 80 anos)

- Eu gostava de jogar cartas. Cartas aqui não há ninguém, não sabem, é só dominó. E eu também sei o dominó, também ia a campeonatos, e a gente ficávamos em segundo lugar, nunca ficamos em primeiro, mas trazia sempre a minha medalha. (...) ĺamos jogar e ainda vinha com medalhas ao peito, tenho minhas medalhas. Gosto de jogar as cartas, gosto. (FO, 92 anos)

- Nunca tinha jogado na minha vida, só aqui é que aprendi. O Quino já é conhecido, o Quino é um jogo familiar que, por exemplo, no natal, quando havia assim muita gente, agora vão faltando, vão desaparecendo, e agente joga isso. E o dominó nunca tinha jogado, mas aprendi aqui. A doutora quis que eu jogasse, aprendi, e agora é todos os dias. (MS, 82 anos)

- Aqui já fizemos muitos teatros. Até íamos a junta fazer teatros. (...) Fizemos, agora é que não. (...) Gostei muito do teatro, porque gostava do teatro. Era uma coisa que agente gostava aqui de fazer, gostávamos muito. Mas as antigas que estão aí é que fazíamos, agora já são muitas modernas, essas nunca fizeram. (AM, 70 anos)

- Já fizemos na junta um tipo de dança, donde entrava várias amigas, que eu gostei muito, foi a primeira vez que eu fiz isso, foi um tipo de dança assim, pronto, uma música muito bonita e gostei imenso, foi com a Dra. Márcia nessa altura. Gostei, gostei muito, foi na Junta da Freguesia do Bonfim, gostei muito, tivemos assim, no palco, e gostei. (...) Esses arranjos que estão aqui todos na entrada da porta, foi todos feitos por mim. E tem muitas atividades feitas por mim, muitas mesmo. (EP, 82 anos)

No CCIB as atividades como teatro, dança e canto coral, apontadas por nós como casuais, ao que pudemos perceber, dependem da atuação de voluntários capacitados, o que nem sempre acontece. As atividades direcionadas para os trabalhos manuais (desenho, pintura, artesanato, etc) não são desenvolvidas com frequência. Os passeios a monumentos e visitas a museus também são esporádicos. Já os jogos (quino, dominó e cartas), são as atividades mais ocorrentes no Centro de Dia.

No que se refere aos jogos, Huizinga (2000) aponta que jogar é uma atividade social considerada também fundamental, uma categoria absolutamente primária da vida, um elemento lúdico que está na base do surgimento e desenvolvimento das civilizações. Segundo o referido autor, o jogo é um complemento e, em última instância, uma parte integrante da vida em geral. Os jogos geralmente são percebidos como práticas para se ocupar o tempo, voltadas para a recreação e diversão, desenvolvidas nas horas vagas. Mais a mais, os jogos também têm uma função biológica, do ponto de vista pessoal, e uma função 
cultural, do ponto de vista social e comunitário. Os jogos são atividades de ocupação voluntária, livre, inútil, gostosa, repetível, capaz de produzir um estado de exaltação, de alegria e dotada de um fim em si mesmo. O mesmo autor comenta que jogar é uma ação que se faz possível num espaço/tempo específico $^{72}$, limitado, com uma organização pré-estabelecida, com regras bem específicas e obrigatórias ${ }^{73}$, e que impõem ordem, tensão, incerteza e alegria.

Quardo 6.7: Atividades recreativas

\begin{tabular}{|c|c|}
\hline \multicolumn{2}{|c|}{ Atividades recreativas e de integração social } \\
\hline Na comunidade & No CCIB \\
\hline Missa dominical & Trabalhos manuais \\
Procissão & Jogos \\
Festas religiosas & Teatro \\
Passeios & Dança \\
--- & Canto coral \\
--- & Decoração para festas \\
--- & Passeios \\
--- & Hidroginástica \\
\hline
\end{tabular}

De acordo com Fonseca (2004), Silva (2009) e Cuenca (2009), permanecer ativo e participativo em atividades que confiram sentido é uma das condições essenciais para se viver bem e com sucesso a velhice. Nesta fase da vida as novas ocupações e as novas possibilidades de comunicação, de ampliação cultural e de participação grupal, entre outras atividades voltadas para a manutenção do lazer e para o exercício do ócio deverão ser colocadas em primeiro plano e ganhar um papel de relevo no cotidiano do indivíduo. É

\footnotetext{
72 Todo jogo se processa e existe no interior de um campo previamente delimitado, de maneira material ou imaginária, deliberada ou espontânea. (...) A arena, a mesa de jogo, o círculo mágico, o templo, o palco, a tela, o campo de tênis, o tribunal etc., têm todos a forma e a função de terrenos de jogo, isto é, lugares proibidos, isolados, fechados, sagrados, em cujo interior se respeitam determinadas regras (Huizinga, 2000, p. 11).

${ }^{73}$ Estas regras são um fator muito importante para o conceito de jogo. Todo jogo tem suas regras. São estas que determinam aquilo que "vale" dentro do mundo temporário por ele circunscrito. As regras de todos os jogos são absolutas e não permitem discussão (Huizinga, 2000, p. 12).
} 
importante que o idoso busque novos caminhos, novos objetivos, novos desafios, novos interesses e novas experiências que possam conferir sentido à sua existência, com o intuito de aumentar a sua capacidade de viver bem e feliz. Sendo assim, cabe ao indivíduo buscar reestruturar, de forma inovadora, o seu dia-a-dia, a fim de substituir aquelas atividades que lhe eram significativas, exercidas no decorrer da sua vida ou do seu papel de trabalhador, por atividades igualmente satisfatórias, já que estas passarão a assumir o meio e o fim central para continuar a mantê-lo ativo, vivo, independente, autônomo e socialmente integrado. A decisão de como melhor ocupar o tempo e torná-lo mais satisfatório e prazeroso, a partir de ocupações que realmente façam sentido, é de extrema importância para a manutenção do bem-estar. A fase da velhice passou a significar hoje o momento propício para a busca de conhecimento, para a busca de lazer como fonte de prazer, para a criação de novos hábitos, novas habilidades e práticas de múltiplas atividades físicas e culturais, enquanto vivências autorealizadoras, autoconscientizadoras e autotransformadoras.

\section{5- A representatividade do clown}

Quem não se recorda daquele tipo ingênuo, atrapalhado, engraçado, risível, com nariz vermelho de bolota, com trajes maltrapilhos ou coloridos, com rufos exagerados ou gravatas esquisitas, com minúsculos chapéus ou sapatos descomunais? Quem não se lembra daquelas cenas de pontapés, de tombos que terminam em cambalhotas, de tapas bem dados e bem levados, de apertos de mãos que não se descolam, de mergulhos em baldes de água? $\mathrm{Na}$ entrevista perguntamos às idosas se elas tinham lembranças da primeira vez que viram um clown (ou palhaço), e as respostas foram as seguintes:

- Meu pai me levava muitas vezes ao circo, eu gostava muito. E depois quando meu filho nasceu, também levava muitas vezes ao circo. (OS, 81 anos)

- Eu já era adulta, quando menina não. Depois de adulta, minha filha até arranjame bilhetes e eu ir ao circo. (MS, 82 anos)

- Foi num circo, que idade eu teria? Sete anos, oito, e gostei (risos). Quando ele tropeçava naquele sapato muito comprido, ia a cair, ficou-me gravado isso. (ME, 77 anos) 
- Quando era novinha gostava muito de ver os palhaços e não só, e o trapézio, não é. Mas o palhaço alegrava-nos quando agente era criança, alegrava-nos muito, e gosto muito, não é. (EP, 82 anos)

- Eu era miúda, talvez com doze, quatorze anos, eu cheguei a ver palhaços. Eu ia com os meus pais e os meus irmãos, íamos ver porque era barato. Fui ver e gosto de ver. (FO, 92 anos)

- Eu então adorava ir ver o circo, mas por causa dos palhaços. Sempre achei muita graça os palhaços, que eles fazem aquelas "pantomices" ali, a bater com os ovos na cara uns dos outros. Eu sempre gostei do circo. (AS, 75 anos)

- Quando eu ia ao circo, principalmente nos circos no natal é que eu ia ver e, gosto, gosto muito de ver, é das coisas que gosto mais. Mas não gosto nada de trapézios, gosto das cenas dos palhaços, que eles fazem. (MC, 70 anos)

- Eu ia com as crianças ao circo, eu tinha quinze, dezesseis anos. Mas a senhoria ia conosco, ia comigo e com as crianças. Mas pra mim era um delírio ver os palhaços, eu gostava imenso, não é. (MM, 88 anos)

- Na escola, na quarta classe, foi lá uns palhaços fazer uma animação pra nós. (...) Depois fui a um circo também, ver com meu marido, e gosto de ver os palhaços, gosto. (RR, 75 anos)

- O circo montava lá a nossa beira. Agente furava por baixo da napa, aquelas coisas de tapar, e agente íamos sempre ver o circo, tinha uns sete anos. $E$ também depois de uma certa idade ia com meus netos ver o circo. Gostava muito. (BP, 71 anos)

- Fui ao circo quando a minha neta era pequenina. Meu filho levava-me e íamos todos ao circo. Quando criança não, lá na aldeia não havia circo, fora os palhacinhos quando era o carnaval. (FC, 80 anos)

- Eu não tive infância nenhuma, eu vim pra cá pra servir. Empregada de casa, (...) eu estava praticamente a olhar pelas crianças, e estive até aos quatorze anos. Eu vi um palhaço já adulta. (MB, 77 anos)

- Eu devia ter só pra aí uns três ou quatro anos, que eu recordo-me de ir ao circo. (LV, 77 anos)

- Já depois de casada, com meus filhos, que eu os levava no carnaval, que era sempre no carnaval que os levava, não é. O que eu não tive, tive que dar aos meus filhos, que eu nunca tive. (AM, 70 anos)

Na entrevista, ao perguntarmos o que o clown representava para as idosas, foi interessante observar que 10 (dez) delas associaram este tipo cômico à figura de um homem triste:

- É uma personagem muito forte, o palhaço, muito forte. Porque às vezes eles estão tristes e tem que fazer rir as pessoas. Acho muito importante o palhaço, muito. (AM, 70 anos) 
- Palhaço é aquilo que nós somos. Nós às vezes escondemo-nos atrás duma palhaçada, estamos a rir, mas por dentro choramos. Acho que palhaço somos todos nós. (ME, 77 anos)

- Por acaso gosto muito de ver palhaços. Os palhaços expõem a vida deles sem agente até perceber que eles estão assim, a dizer a vida deles, e põem-se assim a chorar e tudo, eu acho que isso é mais pra gente dar valor a vida. (BP, 71 anos)

- Eu pra mim representa alegria, embora o palhaço às vezes ri por fora, mas por dentro tá triste. (AS, 75 anos)

- Porque o palhaço é uma coisa muito bonita, muito rica. Por dentro às vezes o palhaço até pode estar muito triste, mas tem que fazer de palhaço pro público. (EP, 82 anos)

- Ora bem, eu admiro o palhaço porque, pronto, quantas vezes eles têm vontade de chorar, porque também tem as suas mágoas e os seus problemas e tem que estar ali no palco a rir-se e a fazer rir os outros. Acho que é uma personalidade que tem que realmente ter a vocação pra aquilo, assim como ator também, não é. Mas acho que palhaço é mais difícil, que é uma vocação mais difícil de fazer. (OS, 81 anos)

- O palhaço pra mim representa uma arte, muito mesmo. Eu acho de ser uma coisa mesmo fascinante. Eu recordo-me de ver um filme que o filho tinha acabado de morrer e ele estava a fazer rir as crianças, portanto, isso é uma arte muito forte $e$ respeito muito. ( $L V, 77$ anos)

- O palhaço representa uma coisa que às vezes me dá pena, porque agente sabe que o palhaço está a fazer rir e às vezes está triste por dentro, não é. Tem a vida dele também pra pensar e pra resolver coisas. Quantas vezes o palhaço está a chorar e fazer rir, não é. (MM, 88 anos)

- Quantas vezes esses homens por trás daquela máscara estão a chorar. E às vezes quando fazem o papel de chorar tão a chorar mesmo. Eu isso acho extraordinário, e acho que nós devíamos respeitar muito mais o palhaço do que já respeitamos, porque eles são extraordinários. (MJ, 70 anos)

- Gosto de os ver trabalhar, eles deitam a vida deles pra trás e faze-nos rir e sabe Deus às vezes como é que estão, não é, porque está mal pra toda a gente. Mas gosto de ver os palhaços a fazer aquelas coisas lá. As vezes costuma fazer a música com a serra e assim, gosto de ver. (RR, 75 anos)

De acordo com Pantano (2007), existem muitas histórias construídas em torno da figura cômica do clown, principalmente no que diz respeito à sua alegria no palco. Uma dessas histórias é a de que por detrás do nariz vermelho existe um homem triste e desiludido. Ou seja, o seu sorriso e a sua alegria seriam apenas aparentes, e a sua máscara um subterfúgio para dissimular certa tristeza no olhar, ou seja, no palco, uma figura cômica por excelencia, fora dele, um homem triste por condição. Conforme a referida autora, a alegria do clown nem sempre condiz 
com o estado de espírito daquele que o desempenha. O palhaço Arrelia, segundo ela, foi um dos muitos clowns que tiveram que fazer rir a plateia, mesmo entristecido. Numa entrevista realizada em Bauro/SP em 1997, o clown "GiraGira" relata um desses momentos vividos pelo palhaço Arrelia:

(...) muitas vezes você está ali doente. Você entra no picadeiro, aquele público não quer saber seu estado emocional, seu estado de saúde. Ele quer saber é de você os fazer rirem. Eles foram ali para assistir o palhaço e querem rir. Agora, o palhaço sabe o quanto ele está sofrendo para fazer o espectador rir. Muitas vezes, isto é um fato até verídico, que veio do palhaço Arrelia, que fez até alguns versos contando essa história. Ele, na sua mocidade interpreta isso e contava aos seus espectadores. Foi o dia em que estava se maquiando, quando chegou um telegrama dizendo do falecimento da mãe dele. $O$ espetáculo não podia parar. O povo pagou, está lá dentro do circo, e o palhaço recebe uma notícia dessa. Agora você precisa ver o estado da alma: arrasou completamente em saber que ele tem que fazer o público rir, com sua alma triste, doente, em saber que sua mãe estava morta. E ele, fazendo rir e chorando por cima da pintura do seu rosto, feliz ele sentiu-se quando terminou o espetáculo, no seu camarim escuro, naquela barraca escura maldizendo a sua desventura! Foi quando ele pôde à vontade chorar pela morte da sua mãe.

Este seria, segundo relatos, um dos desprazeres da profissão do clown, fingir que está alegre quando na verdade "se está triste por dentro", como disseram algumas idosas. Contudo, as histórias que permeiam esta figura cômica nem sempre condizem com a realidade dos clowns. A história do palhaço Arrelia é apenas mais uma das inúmeras histórias que fazem parte do mundo do circo.

$\mathrm{Na}$ entrevista 06 (seis) idosas também associaram o clown à figura do homem pobre e do homem rico, evidenciando a relação entre dois clowns, supostamente a relação entre o clown Branco e o Augusto:

- Pra mim o palhaço significa uma profissão muito importante, senão das mais importantes. Porque muitas vezes o palhaço, principalmente como chamamos aqui, o palhaço pobre, era aquele que mais fazia rir. (MJ, 70 anos)

- O palhaço é o que entretém as pessoas. Há o rico e o pobre. O pobre é inferior ao outro, o rico é que manda nele, é que brinca com ele. O outro faz sempre de inocente. (MS, 82 anos) 
- Os palhaços é o rico e o pobre. (...) Gosto mais, talvez, do trabalho do pobre do que do rico. (MC, 70 anos)

- O palhaço pobre faz papel de muito ingênuo, mas, visto bem, é mais inteligente que o palhaço rico. (RR, 75 anos)

- O rico é mesmo mal, abusa do palhaço pobre. Quando miúda eu gostava mais do pobre, não é, ele era mais engraçado. (BP, 71 anos)

- Aqueles dois, os dois de resto, a fazer aquelas brincadeiras, aquelas maluquices, eu gosto disso. (FO, 92 anos)

De fato existem dois tipos clássicos de clowns: o Branco e o Augusto. Conforme Burnier (2001), o primeiro clown, o Branco, é a representação do patrão, o cerebral, o intelectual, o prepotente, o mandão, o que está sempre pronto a enganar o seu parceiro em cena. Já o Augusto, é a encarnação do bobo, o tolo, o emocional, o perdedor, o ingênuo, o de boa-fé, que está sempre sujeito ao domínio do clown Branco. Quando os dois clowns atuam juntos, servindo de contraponto um ao outro, as relações e os jogos entre eles se tornam mais ricos, contribuindo ainda mais para a comicidade do espetáculo. Esta tática de contraponto permite ao tolo superar o intelectual ou, por assim dizer, ao mais fraco se sobrepor ao mais forte, fazendo triunfar, desta maneira, "a pureza sobre a malícia" ou "o bem sobre o mal". Neste jogo de contraponto a dupla de clowns pode representar: o senhor e o servo; o patrão e o empregado; o rico e o pobre. Este último, o pobre, expoente dos excluídos, geralmente é o que tem as melhores piadas, é quem responde sempre à altura do rico, que por sua vez, sai do palco valentemente gozado. Mediante o autor supracitado, a plateia geralmente tende a se identificar e a criar uma empatia maior pelo Augusto, ou seja, pelo clown tolo. 


\section{CAPÍTULO VII}

\section{OCORRÊNCIA DA PESQUISA-AÇÃO}

\section{1- O Processo de Criação do Clown}

Com base nos referenciais teóricos apreendidos, e mesclando as informações obtidas por meio das entrevistas e diários de bordo ${ }^{74} \mathrm{com}$ as percepções do investigador (suscitadas no processo de observação), com imagens fotográficas e trechos das falas das participantes (coletadas durante 0 percurso prático), buscaremos, sem obediência a um método a rigor, fazer uma descrição generalizada das atividades e técnicas - corpo, expressão corporal, jogos tradicionais, jogos teatrais e exercícios clássicos de clown - desenvolvidas no decorrer do programa, e que fazem parte ocorrente em processos de criação do clown.

Buscaremos, também, verificar os efeitos resultantes do processo prático, que nos possibilitou um olhar multifacetado sobre a realidade vivida por cada uma das idosas nos contextos observados, com a finalidade de identificarmos e obtermos provas para darmos respostas às questões levantadas: A aplicação de um processo de criação do clown num contexto social atribuído à velhice pode possibilitar bem-estar e potencializar a vida? As atividades e técnicas que atravessam este processo podem ser percebidas como possibilidades de experiências de ócio?

O programa Humor e Bem-estar na Velhice, como já foi mencionado, foi implementado e executado no Centro de Convívio para Idosos do Bonfim (CCIB), na Junta da Freguesia do Bonfim, na cidade do Porto, em Portugal. O grupo representativo foi constituído por 16 (dezesseis) idosas, todas frequentadoras do CCIB, com idades compreendidas entre os 70 e 92 anos, e funcionalmente independentes.

\footnotetext{
${ }^{74}$ Os diários de bordo, como meio para coleta de dados, não surtiu o efeito esperado, dado ao fato das idosas apresentarem dificuldades com a escrita, o que não quer dizer que não tivesse sido válido, já que conseguimos um e outro registro acerca da vivência de uma e outra participante sobre as atividades desenvolvidas e sobre a experienciação do clown.
} 
No que diz respeito ao grupo representativo, como já conferimos, tivemos uma unanimidade de mulheres (100\%), uma predominância de mulheres com idades entre os 70 e os 79 anos (56,25\%), uma predominância de mulheres viúvas $(87,50 \%)$, uma predominância de mulheres com escolaridade entre o $1^{\circ} \mathrm{e}$ $4^{\circ}$ ano $(81,25 \%)$ e uma unanimidade de mulheres reformadas $(100 \%)$. O perfil de maior representatividade foi de idosas com menos de 80 anos de idade, com formação básica, viúvas e reformadas.

O programa Humor e Bem-estar na Velhice foi executado entre os dias 08 de abril e 23 de setembro de 2014, e teve lugar num espaço cedido pelo CCIB, que nos disponibilizou todo o apoio e toda a logística necessária para a sua execução: uma sala ampla, iluminada e ventilada, com armário, mesa, cadeiras, poltronas e equipamento de som, devidamente apropriada para o cumprimento das atividades e para a segurança e comodidade das idosas.

As sessões, que somaram um total de 23 (vinte e três), tiveram uma frequência semanal de 03 (três) horas de atividades, ocupando todas as terçasfeiras do referido período, no horário das 14 às 17 horas.

O processo prático, que decorreu de forma natural, implicou não só a participação ativa dos agentes implicados na pesquisa, mas também do investigador, cabendo a ele assumir os dois papéis, de observador e de participante. Neste processo o investigador foi envolvido no contexto da prática de modo cooperativo e participativo, face-a-face com os sujeitos observados, atuando como mais um membro do grupo ao mesmo tempo que o observava. A vantagem de o investigador assumir estes dois papéis residiu na oportunidade de estar disponível para reunir dados pormenorizados e significantes, fundamentados na ocorrência da situação e baseados no que aconteceu, ou seja, naquilo que ele viu e ouviu, além de coletar relatos de situações na própria fala das participantes.

Os dados apresentados no quadro 7.8 versam sobre a frequência das idosas no decorrer das 23 (vinte e três) sessões de atividades, demonstrando uma frequência global de $72,22 \%$ das participantes. Como demonstra o quadro abaixo, a frequência durante os meses de julho e agosto foi um pouco menor, em decorrência das férias de verão, dado ao fato de algumas idosas terem se ausentado para viajar com a família. 
Quadro 7.8: Quadro de frequência

\begin{tabular}{|c|c|c|c|c|}
\hline \multicolumn{5}{|c|}{ Programa Humor e Bem-estar na Velhice } \\
\hline \multicolumn{5}{|c|}{ Abril/ 2014} \\
\hline Data & 08 & 15 & 22 & 29 \\
\hline Frequência & 14 & 16 & 16 & 15 \\
\hline \multicolumn{5}{|c|}{ Maio/ 2014} \\
\hline Data & 06 & 13 & 20 & 27 \\
\hline Frequência & 15 & 14 & 16 & 16 \\
\hline \multicolumn{5}{|c|}{ Junho/ 2014} \\
\hline Data & 03 & 10 & 17 & \\
\hline Frequência & 15 & 13 & 11 & \\
\hline \multicolumn{5}{|c|}{ Julho/ 2014} \\
\hline Data & 08 & 15 & 22 & 29 \\
\hline Frequência & 12 & 10 & 11 & 11 \\
\hline \multicolumn{5}{|c|}{ Agosto/ 2014} \\
\hline Data & 05 & 12 & 19 & 26 \\
\hline Frequência & 13 & 13 & 14 & 15 \\
\hline \multicolumn{5}{|c|}{ Setembro/ 2014} \\
\hline Data & 02 & 09 & 16 & 23 \\
\hline Frequência & 13 & 14 & 14 & 13 \\
\hline
\end{tabular}

\section{2- A linguagem do clown como instrumental para humorizar a vida}

Logo nas primeiras sessões, antes de partirmos para as atividades práticas, buscamos - de forma resumida, simples e compreensível - falar um pouco sobre a arte do clown: sua origem; sua elaboração; sua caracterização; seu espaço de atuação; seu treinamento; e suas habilidades. Buscamos também elucidar e discutir alguns dos princípios que regem a sua personificação, para o entendimento de uma proposta que utilizaria a sua máscara como elemento de experimentação. Estes princípios, ainda que basilares, serviriam de "bússola" para nortear as idosas na busca e elaboração do seu clown pessoal: 
i. Num primeiro olhar podemos pensar que o clown é um personagem e, como tal, construído como uma figura dramática separada daquele que o desempenha. Contudo, um clown não se representa, ele "é", não se trata de um personagem, mas da exposição e dilatação da excentricidade do próprio sujeito, ou seja, do seu lado tolo e ridículo, tão bem camuflado;

ii. O clown vê o mundo do avesso, ao mesmo tempo que revela o avesso do sujeito;

iii. O nariz vermelho é o olho do clown, ele fornece o foco. Já os olhos, estes são a sua alma, revelam o seu estado de alegria;

iv. O clown sempre diz "sim" para o jogo, ele adora jogar e adora conflito. Solução para ele é sinônimo de problematizar;

v. O clown adora o palco, ele sente profunda alegria por estar em cena, por estar atuando junto da plateia;

vi. O clown não planeja, ele está em cena e simplesmente age. Sua atuação ancora-se na improvisação, nas relações estabelecidas no palco, no ambiente, no jogo com a plateia;

vii. O clown é muito curioso, ele olha tudo ao seu redor como se fosse a primeira vez. Ele é profundamente interessado no mundo, nas pessoas e nos objetos. Das menores às maiores coisas ele tenta tirar o máximo proveito;

viii. A lógica do clown não depende de grandes elaborações, ela nasce no ato da atuação, surge da sua relação com o mundo redescoberto;

ix. O clown é movido pelo impulso lateral das palavras, se dizem a ele que a noite caiu certamente ele sairá procurando a noite no chão (Jardim, 2002).

Ao falarmos do clown buscamos mencionar não só aquele tipo cômico cuja tradição está fortemente ligada ao circo e ao teatro, mas também de uma figura que, segundo Kleber (2012), ganhou novos contornos, novos locais e ressurgiu com grande vitalidade nos mais diversos lugares, sempre apoiado na arte do improviso, nos jogos e nas situações corriqueiras do cotidiano e da vida. Nos dias atuais os clowns atuam em vários territórios, estão inseridos em contextos e setores diversos, como por exemplo: no circo, no teatro, nas praças, ruas, festivais, festas, concertos, hospitais, escolas, creches, asilos, empresas, etc. 
No decorrer das primeiras sessões observamos que a discussão sobre o clown atraiu facilmente o espírito cômico das idosas, como também incitou o interesse e a curiosidade de cada uma delas, fosse em relação ao trabalho do clown, fosse em relação ao processo prático. As idosas queriam saber "tudo e mais um pouco" sobre a atuação do clown e sobre as atividades que seriam desenvolvidas. Em uma das sessões perguntamos às idosas como elas, em uma única palavra, definiam a figura do clown. As respostas foram as seguintes:

Quadro 7.9: Definição de clown

\begin{tabular}{|c|c|}
\hline Definição & Número de idosas \\
\hline Cômico & 1 \\
Engraçado & 5 \\
Alegre & 3 \\
Divertido & 1 \\
Feliz & 1 \\
Bobo & 2 \\
Debochado & 1 \\
Faz piadas & 1 \\
Diz asneiras & 1 \\
\hline
\end{tabular}

Todas estas características, de fato, condizem com a figura do clown. Segundo Kleber (2012), o clown é uma figura cômica por excelência, ele é herdeiro de toda uma tipologia da máscara do riso, passando pela baixa comédia grega e romana, pelos bufões da antiguidade, pelos bobos da corte da idade média, pelos festejos carnavalescos medievais, pelo teatro popular e religioso da renascença, pela commédia dell'arte italiana e por todos aqueles histriões que buscavam seu espaço de atuação nas feiras e praças. Conforme o referido autor, independente da profusão de nomes que estes cômicos assumiam, se bufão, histrião, truão, gracioso, jogral, bobo, grotesco, excêntrico ou saltimbanco, como também do tempo e lugar, eram tipos dotados de um vocabulário polivalente, de uma linguagem popular ordinária, hilariante, obscena, obscura, incorreta e de duplo sentido, bem ao gosto dos temperamentos humanos e das fraquezas 
morais, sendo sempre interpretados como loucos, idiotas, divertidos, chocarreiros, toscos e extravagantes, capazes de provocar gargalhadas ao primeiro olhar. $\mathrm{Na}$ atualidade o clown (ou palhaço), como os seus antecessores, também é interpretado como louco, pela sua excêntricidade, pelo seu comportamento inusitado, pelas suas imitações grotescas, pelas suas chacotas, piadas e faltas de conduta.

No decorrer das sessões, por várias vezes, fomos interrompidos com perguntas, comentários hilários, gargalhadas e palmas. Era visível nos rostos alegres e nas falas entusiasmadas das idosas o fascínio pela figura do clown. Seguem alguns comentários:

- Fiquei a conhecer mais um bocadinho da representação do palhaço. Estou muito curiosa com o seguimento do processo. (MJ, 70 anos)

- Aprender coisas novas é sempre muito bom. O mundo do palhaço é muito mais bonito do que eu imaginava. (MB, 77 anos)

- Fazer rir, distrair agente, distrair a todos nós. É preciso ter o perfil do palhaço pra fazer rir e pra se divertir também. É preciso ter um bocadinho o perfil do palhaço, é sim senhor, pra fazer rir e divertir as pessoas. (FC, 80 anos)

- O próprio nome diz, é palhaço, gosta de fazer rir agente, e eu gosto muito. Por acaso gosto muito dos palhaços, porque eles entretêm bem agente. Deixa agente bem-disposta. (MB, 77 anos)

- Eu acho que isto é muito importante pra nós, porque agente vai aprendendo. (EP, 82 anos)

\section{3- "Jogando a bengala": da quietude para a ação}

Apesar de o Centro de Convívio para Idosos do Bonfim (CCIB) oferecer um conjunto de atividades e dar espaço para que os idosos exponham seus talentos, observamos que uma parte dos seus frequentadores, principalmente aqueles de mais idade, passavam boa parte do tempo sentados, quase sem ação ${ }^{75}$.

\footnotetext{
${ }^{75}$ No CCIB as atividades como teatro, dança e canto coral, apontadas por nós como casuais, ao que pudemos perceber, dependem da atuação de voluntários capacitados, o que nem sempre acontece. As atividades direcionadas para os trabalhos manuais (desenho, pintura, artesanato, etc.) não são desenvolvidas com frequência. Os passeios a monumentos e visitas a museus também são esporádicos. Já os jogos (quino, dominó e cartas), são as atividades mais recorrentes.
} 
De acordo com Fonseca (2004), embora a quietude e o descanso estejam atrelados a momentos mais tardios da vida, os efeitos associados à inatividade podem acentuar ainda mais as perdas da capacidade funcional, além de acarretarem uma diminuição do desempenho físico e da habilidade motora, gerando processos como a falta de motivação e até mesmo o isolamento social. Berge (1975) assinala que na fase da velhice os efeitos da inatividade podem ameaçar até mesmo o plano gestual, isto é, se os membros e os músculos permanecem inativos eles perdem o gosto pelo movimento e tornam-se inábeis.

Ainda no que diz respeito à inatividade, outra verificação se deu por meio da entrevista. Consoante as respostas dadas pelas idosas inscritas no programa, em suas casas elas passam mais tempo sentadas ou deitadas do que o contrário, por se sentirem, segundo elas, doentes, fracas, desprovidas de condições físicas e cansadas. Em casa elas se ocupam, quase que unicamente, com tarefas intradomiciliares básicas, como por exemplo: preparo de alimentos; limpeza doméstica; lavar e passar roupa. Tarefas estas, consideradas comuns e de fácil execução, mas que com o passar do tempo foram se tornando cada vez mais difíceis de serem realizadas. Segundo as idosas, elas se acham lentas e mais descuidadas com a casa, em razão das doenças, da diminuição do vigor físico, da lentidão dos movimentos, da dificuldade de locomoção, da redução do controle postural, da falta de flexibilidade, da má visão e da falta de estímulos, que são alguns dos fatores, como aponta a literatura, que mais se evidenciam com o aumento da idade. Quanto às atividades domiciliares recreativas, voltadas para o entretenimento e para o descanso, as idosas, quando bem-dispostas, ocupam o seu tempo assistindo televisão (novelas e noticiários), fazendo trabalhos manuais (renda e malha), ouvindo música, lendo e/ou cuidando de plantas.

De acordo com a Organização Pan-Americana da Saúde (Opas) (2012), a capacidade de o idoso realizar atividades básicas cotidianas, mesmo as recreativas, está intimamente relacionada com a sua capacidade gestual, isto é, com a sua capacidade individual de movimento e de manipulação do meio onde ele está inserido. Esta capacidade, segundo a Opas, deve ser estimulada e desenvolvida por meio de atividades físicas regulares, para que os idosos consigam se manter ativos e independentes em seus lares pelo maior tempo de vida possível. 
Face a esta verificação, buscamos elaborar e inserir no nosso "Sistema de atividades" um conjunto de práticas voltadas para o trabalho de corpo e de expressão corporal, como também jogos tradicionais, jogos teatrais e exercícios clássicos de clown. Todos estes procedimentos, que fazem parte ocorrente em processos de criação do clown, foram devidamente adaptados à realidade e às necessidades físicas e psíquicas das idosas. Tínhamos como propósito:

1. Tirar as idosas do "estado de quietação" e passá-las para o "estado de atitude e ação", visando restabelecer o movimento corporal e a autonomia motora, a partir das atividades de corpo;

2. Desenvolver nas idosas a sensibilidade, a imaginação, a criação, a interação, a comunicação, a expressão e a desinibição corporal, por meio da fisicalização de pensamentos, sentimentos, emoções, sensações, necessidades e desejos, a partir do trabalho de expressão corporal;

3. Proporcionar às idosas momentos de descanso, recreação e evasão, além de estimular e desenvolver suas capacidades, competências e habilidades cognitivas e adaptativas, como a percepção, a atenção, a concentração, a memória, o controle emocional e a linguagem, a partir dos jogos tradicionais;

4. Levar as idosas a experienciar o trabalho do clown e da encenação, a desenvolver a livre improvisação, a espontaneidade e o sentido de ação e de jogo, a partir dos jogos teatrais.

\subsubsection{As atividades de Corpo:}

Para as atividades de corpo preparamos um conjunto de exercícios e de técnicas voltadas para o trabalho de preparação, conscientização e sensibilização corporal, como por exemplo: procedimentos de aquecimento, alongamento, massagem e relaxamento corporal; e técnicas de integração postural, a partir da percepção de posturas (eixos corporais, postura correta), bases de apoio, colocação do quadril, equilíbrio, transferência de peso, forma correta de caminhar, sentar, abaixar e levantar. 
O objetivo principal do aquecimento corporal é aumentar a temperatura do corpo, com o intuito de evitar lesões. As dinâmicas de alongamento contribuem para uma melhor flexibilidade e fluidez dos movimentos ${ }^{76}$. As massagens são estimulantes e produzem uma sensação de revigoramento, como também de alívio da ansiedade e da tensão causadas pelo estresse do dia-a-dia. $O$ relaxamento constitui um processo psicofísico que promove o descanso muscular e mental, produzindo a sensação de alívio, de leveza e de bem-estar. De acordo com Augusto Boal (1978), procedimentos como estes, além de descontraírem e estimularem os músculos pouco usados na rotina diária, terminam por alterar aquelas circunstâncias habituais que mecanizam o corpo, os movimentos, a sensibilidade e até mesmo as ideias.

Por se tratar de um grupo de pessoas com idades avançadas e bastante vulneráveis, buscamos desenvolver as dinâmicas de aquecimento e alongamento corporal de forma leve, de modo controlado, em baixa intensidade, de modo gradual e suficientes, haja vista que os movimentos dos idosos, de um modo geral, são mais lentos, menos precisos, mais hesitantes e com um tempo de reação menor. Segue como exemplo 01 exercício de aquecimento corporal dirigido ao grupo:

\section{Aquecimento corporal}

Propor movimentos: em círculo. Uma pessoa vai para o centro e produz uma sequência aleatória de movimentos, de forma livre e espontânea, buscando explorar todas as partes do corpo. À medida que os movimentos vão surgindo os demais participantes vão tentando reproduzir os mesmos movimentos.

No decorrer das dinâmicas de aquecimento e alongamento corporal pudemos observar que a extensão e o tempo dos movimentos produzidos pelas idosas variavam de pessoa para pessoa, ainda que da mesma faixa etária. No decorrer dos exercícios algumas delas apresentaram um melhor condicionamento físico, enquanto outras, demonstraram maiores dificuldades e limitações corporais.

${ }^{76}$ Com pessoas idosas o alongamento deve ser mantido por pelo menos 60 segundos, de forma suave, tomando os devidos cuidados para evitar lesões. 
Percebemos, também, a dificuldade das idosas em ficar de pé por um tempo mais prolongado. Decorrido um tempo de aproximadamente 10 minutos de trabalhos corporais as idosas pediam para sentar, alegando estarem cansadas. Contudo, o fato de ficarem sentadas, ainda que por um tempo indeterminado, não dificultou, muito menos impediu, o desenvolvimento dos trabalhos de preparação corporal. Mesmo sentadas as idosas conseguiram realizar, habilmente, pequenos exercícios, tais como: aquecimento das mãos, dos braços e das pernas; aquecimento da articulação do pescoço, dos ombros, dos pulsos e tornozelos; alongamento da coluna vertebral, dos braços, das pernas e dos pés; movimentos livres (como espreguiçar alongando, de acordo com as próprias necessidades); massagem facial; exercícios de respiração; exercícios de técnica vocal; e relaxamento corporal. Todos estes procedimentos foram progredindo de maneira crescente a cada sessão de trabalho e foram aplicados sempre que necessário, isto é, antes, durante e até mesmo depois das sessões. O mais importante foi estimularmos o movimento, para que a motricidade corporal das idosas fosse aumentada e reforçada.

No que concerne à massagem, segundo Gil (2001), ela não comporta apenas um aspecto mecânico, mas também a abertura de canais energéticos. Esta troca de energia entre dois corpos, que se dá a partir do contato físico, permite reduzir as tensões e o estresse, cujos estados, além de provocarem dores e fadiga muscular, terminam por reduzir a capacidade de enfrentamento do dia-a-dia. Conforme o referido autor, quando estas tensões não são liberadas criam-se dores, cansaço e mal-estar, para além do desejável.

Quanto ao relaxamento, mediante Berge (1975), ele serve de "banho purificador", a fim de que as crispações habituais possam ser apercebidas e eliminadas. Seguem 02 exercícios como exemplo:

\section{Massagem corporal}

Os participantes fazem duas filas, uma de frente para a outra. Cada um deles massageia o rosto do outro: primeiro com movimentos em cruz, enérgicos, sobre cada sobrancelha, de cada lado do nariz, no queixo, no pescoço e sobre os ombros. Depois, suavemente, com movimentos circulares, nos mesmos pontos. 


\section{Relaxamento corporal}

Sentados sobre cadeiras. Relaxar a coluna vertebral, os ombros, os braços e as mãos. Relaxar as pernas e os pés. Fechar os olhos e esvaziar a mente. Respiração nasal, filtrando o oxigênio. Inspirar suavemente, enchendo os pulmões. Expirar suavemente, soltando o ar pela boca. Inspirar e expirar.

No decorrer do processo as sessões de massagem e relaxamento foram percebidas como o fechamento de um conjunto de exercícios corporais. Foi o momento da percepção e absorção de todas as vivências ocorridas durante o treinamento físico, ou seja, foi o momento pleno de encontro das idosas consigo mesmas, foi o momento de interiorização e de autorreconhecimento.

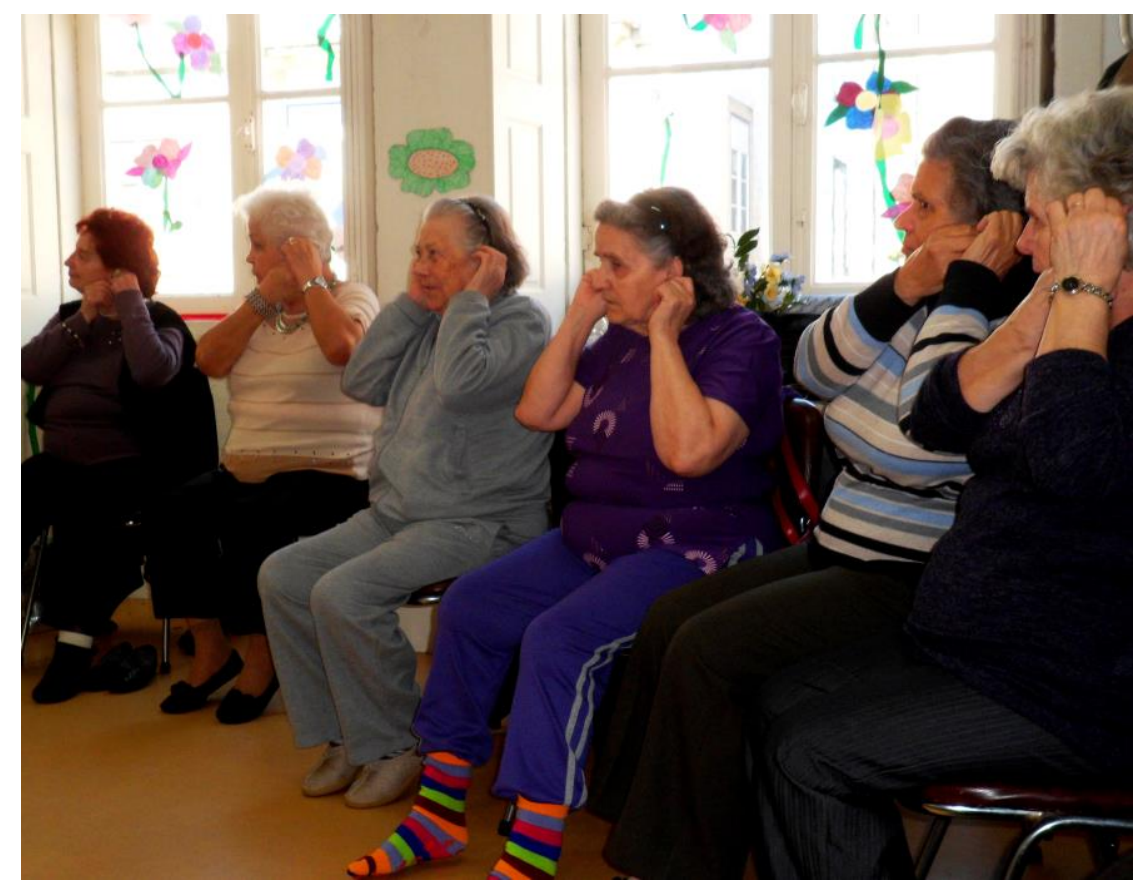

Imagem 05: Massagem facial

Quatro idosas proferiram que as sessões de massagem e relaxamento provocaram nelas uma sensação de "diminuição das dores do corpo", de "descanso da mente", de "leveza" e de "paz interior":

- Sinto-me mesmo muito bem, é uma sensação de leveza. Como hei de explicar?! É uma sensação boa, que faz-me bem. (BP, 71 anos) 
- Eu estou muito gorda, não é, já não consigo fazer muita coisa. A massagem que temos feito aqui tem me ajudado bastante, não é. Ajuda a diminuir as dores do corpo. (AM, 70 anos)

- Senti um relaxamento muito bom. Foi um momento de descanso pra minha mente. E aprendi alguns pormenores que nunca me tinha apercebido. (MJ, 70 anos)

- Eu sinto que o relaxamento toca a alma das pessoas, é uma coisa muito boa, muito boa mesmo. Senti uma paz interior muito grande. (MM, 88 anos)

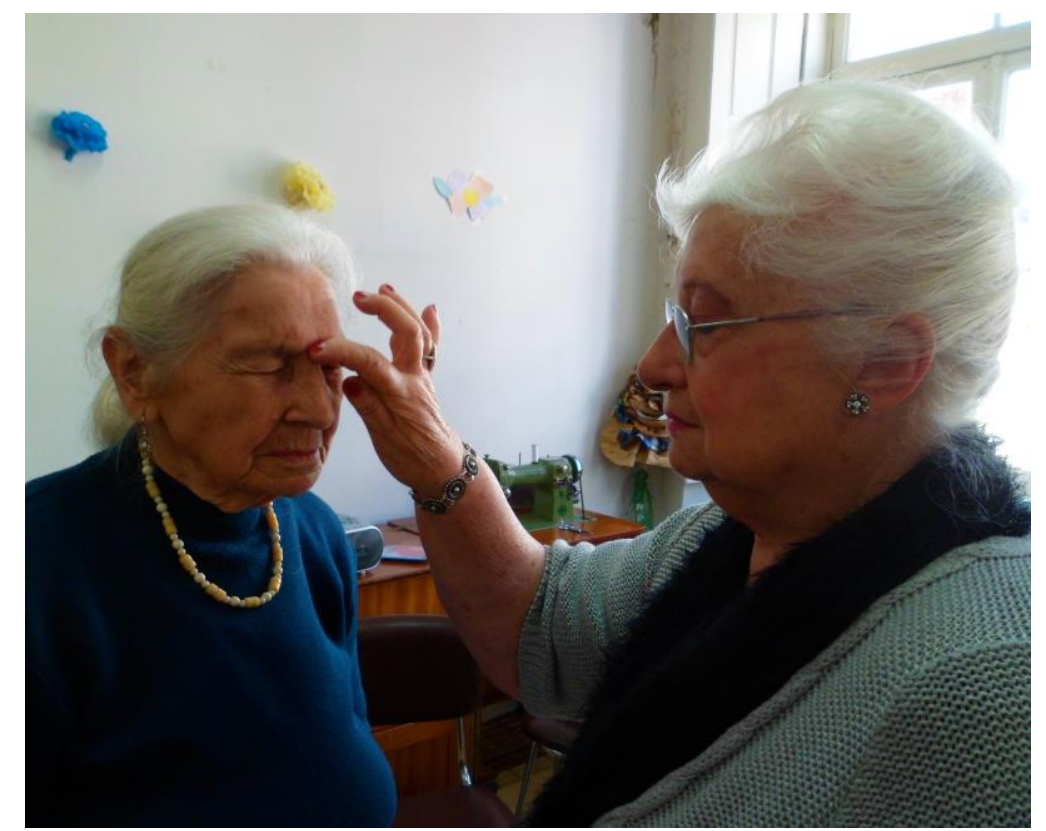

Imagem 06: Relaxamento corporal

Uma outra dificuldade das idosas, verificada no decorrer das atividades de preparação corporal, é a de lidar com padrões posturais e com movimentos limitadores. De acordo com a Organização Pan-americana de saúde (2012), algumas das síndromes geriátricas dos idosos são a imobilidade e a instabilidade postural, que tem como complicações as quedas. A inibição ao nível do controle postural, a falta de equilíbrio e a diminuição dos reflexos, por exemplo, constituem-se como alguns dos fatores que mais se evidenciam com o aumento da idade, daí as frequentes quedas na velhice. Na fase da velhice o medo que o indivíduo tem de cair é frequente e pode desencadear o ciclo vicioso da imobilidade. Segundo a Opas, "esse declínio normalmente não traz nenhuma restrição da participação social do indivíduo, apesar de caracterizar uma deficiência" (Opas, 2012, p. 24). 
De acordo com Bize e Vallier (1985), a senescência caracteriza-se como um processo de comprometimento da capacidade de adaptação do corpo, que está associada ao processo de declínio e deterioração biológica: deterioração do sistema ósseo; acentuação da curvatura dorsal; diminuição do tônus muscular; enfraquecimento dos joelhos; perca da mobilidade; perca da força das articulações; surgimento de lesões degenerativas (artrose e osteoporose); perturbações do equilíbrio em postura vertical; andadura mais lenta e menos segura; gestos menos precisos e hesitantes. Os referidos autores apontam que:

i. Com a idade há uma maior oscilação, indícios, ainda que leves, de perturbações do equilíbrio em postura vertical;

ii. Os músculos sofrem perturbações de três ordens: atrofia, diminuição do tônus muscular e diminuição da força;

iii. A andadura torna-se mais lenta e menos segura, sendo necessário recorrer a uma bengala para apoio durante as caminhadas e/ou corrimão para subir ou descer escadas;

iv. As articulações perdem a força e a mobilidade, tornando-se local de reumatismos crônicos e lesões degenerativas que atacam, mais frequentemente, a articulação dos quadris, dos joelhos, dos dedos grandes dos pés e das mãos, das espáduas e da coluna lombar e cervical;

v. Os movimentos tornam-se cada vez mais lentos, sendo uma das manifestações mais evidentes o tremor, que pode manifestar-se nos membros superiores, na cabeça ou quando se passa do estado de repouso para a ação.

Squire (2005) comenta que o controle da postura e dos movimentos representa um grande desafio para os idosos. A aquisição de uma postura incorreta pode ocasionar déficits em pequenas ações, como por exemplo, ficar em pé, levantar de uma cadeira, caminhar, abaixar para apanhar um objeto, vestir uma roupa, realizar uma atividade qualquer, entre outras tantas ações que um idoso pode executar no seu dia-a-dia. Face a isto, e apostando na segurança, na comodidade e no bem-estar das idosas, buscamos desenvolver um conjunto de técnicas de integração postural, a partir da percepção de posturas (eixos corporais, postura correta), bases de apoio, colocação do quadril, equilíbrio, 
enraizamento, transferência de peso, forma correta de caminhar, sentar, abaixar e levantar. Tínhamos como propósito não só levar as idosas a reencontrar um melhor equilíbrio em postura vertical e uma correção postural harmoniosa, alicerçada e segura, mas também levá-las a desenvolver uma maior dinamicidade e segurança no caminhar, que são habilidades indispensáveis para o bom andamento das atividades de expressão corporal. Seguem como exemplo 02 exercícios de integração postural desenvolvidos com o grupo:

\section{Integração postural A}

Todos de pé/ pés paralelos, na direção dos quadris/ joelhos levemente flexionados/ quadril encaixado/ dividir o peso entre as duas pernas/ coluna vertebral ereta/ corpo empilhado/ abrir o peito/ fechar as costas/ maxilar paralelo à linha do chão/ olhar na linha do horizonte/ ombros relaxados/ braços soltos e relaxados/ perceber o equilíbrio.

\section{Integração postural B}

Caminhar lentamente/ pisar com o calcanhar, planta dos pés, dedos/ levantar os pés do chão/ não calcar o chão com os pés/não deslizar os pés no chão/ coluna ereta/ maxilar paralelo à linha do chão/ transferir o peso de uma para outra perna/ ocupar os espaços vazios/ parar/ ao mudar de direção girar primeiro a cabeça, em seguida os ombros, o tronco e o quadril/ alternar o ritmo/ lento, normal, rápido/ parar/ caminhar.

No decorrer das atividades corporais buscamos também reservar alguns minutos para os exercícios de respiração e de técnica vocal. Os exercícios de respiração, a saber, são parte integrante e um dos princípios chave de qualquer atividade física. Segundo Bege (1975), manter uma respiração correta é indispensável para a reconstituição das forças vitais. Uma boa respiração ajuda a relaxar a musculatura e a controlar os movimentos, como também provoca apaziguamento e a sensação de bem-estar psicofísico.

Já nos exercícios de técnica vocal, buscamos desenvolver alguns procedimentos bem simples, orientados para o aquecimento, alongamento e 
higienização vocal. Aplicamos também alguns exercícios de articulação e fonação (intensidade e qualidade vocal), que abrangeram a fala/voz, audição e motricidade oral. Estes exercícios, mesmo breves, vieram contribuir para a desenvolvimento da comunicação verbal das idosas. Seguem 02 exemplos de exercícios orientados ao grupo:

\section{Exercício de respiração}

1. Sentar, confortavelmente/ manter a coluna ereta/ levar o queixo, ligeiramente, em direção ao peito/ ombros leves e relaxados/ pés paralelos, separados e apoiados no chão/ braços soltos e relaxados/ colocar as mãos sobre as costelas, de tal forma que as pontas dos dedos não se toquem/ fechar os olhos/ respiração torácica/ inspirar pelo nariz, filtrando o oxigênio/ encher os pulmões de ar/ soltar o ar pela boca, suavemente/ inspirar novamente/ expirar suavemente.

\section{Exercícios de técnica vocal}

1. Aquecimento vocal:

Fechar a boca/ respirar fundo/ começar soando o som hummmmm. O som (grave) fica armazenado na faringe (cavidade no começo da garganta). Inicie com um tempo de 10 segundos para o som/ parar/ inspirar novamente e recomeçar o exercício aumentando o tempo de duração do som. Repetir por 05 vezes;

2. Dicção (utilizando trava-linguas):

Articular bem os lábios/ exagerar nos movimentos da boca/ movimentar também a face/ pronunciar bem as palavras: ex: o sabiá não sabia que 0 sábio sabia que o sabiá não sabia assobiar/ tal tatu ta tendo um trimetraco troco um treco por tramóia com a traquina da jibóia;

3. Vocalise:

Bocejar antes dos exercícios/ relaxar o rosto, o pescoço e a lingua/ inspirar/ reproduzir frases musicais: ex: mi-ni-ma-ne-mi/ mo-i-o-i-o. 
Os procedimentos de aquecimento, alongamento, massagem $\mathrm{e}$ relaxamento corporal, como também as técnicas de integração postural e os exercícios de respiração, foram aplicados no decorrer de todo o processo prático. Estes procedimentos vieram ao encontro das necessidades das idosas, como por exemplo: em adquirir uma maior vitalidade corporal; em adquirir uma maior desenvoltura dos movimentos; em adquirir uma maior segurança em relação ao próprio corpo; em adquirir uma maior independência pessoal; em adquirir uma maior confiança em si próprias; em adquirir uma melhor respiração. Todos os exercícios desenvolvidos no decorrer do processo foram se tornando, pouco a pouco, pontos de referência cada vez mais seguros. Recorto e destaco aqui a fala de uma das idosas:

- Professor, o senhor percebeu que eu agora não estou a utilizar a minha bengala de apoio quando vou pra os exercícios? Eu estou mais confiante, inclusive nas minhas colegas. (AS, 75 anos)

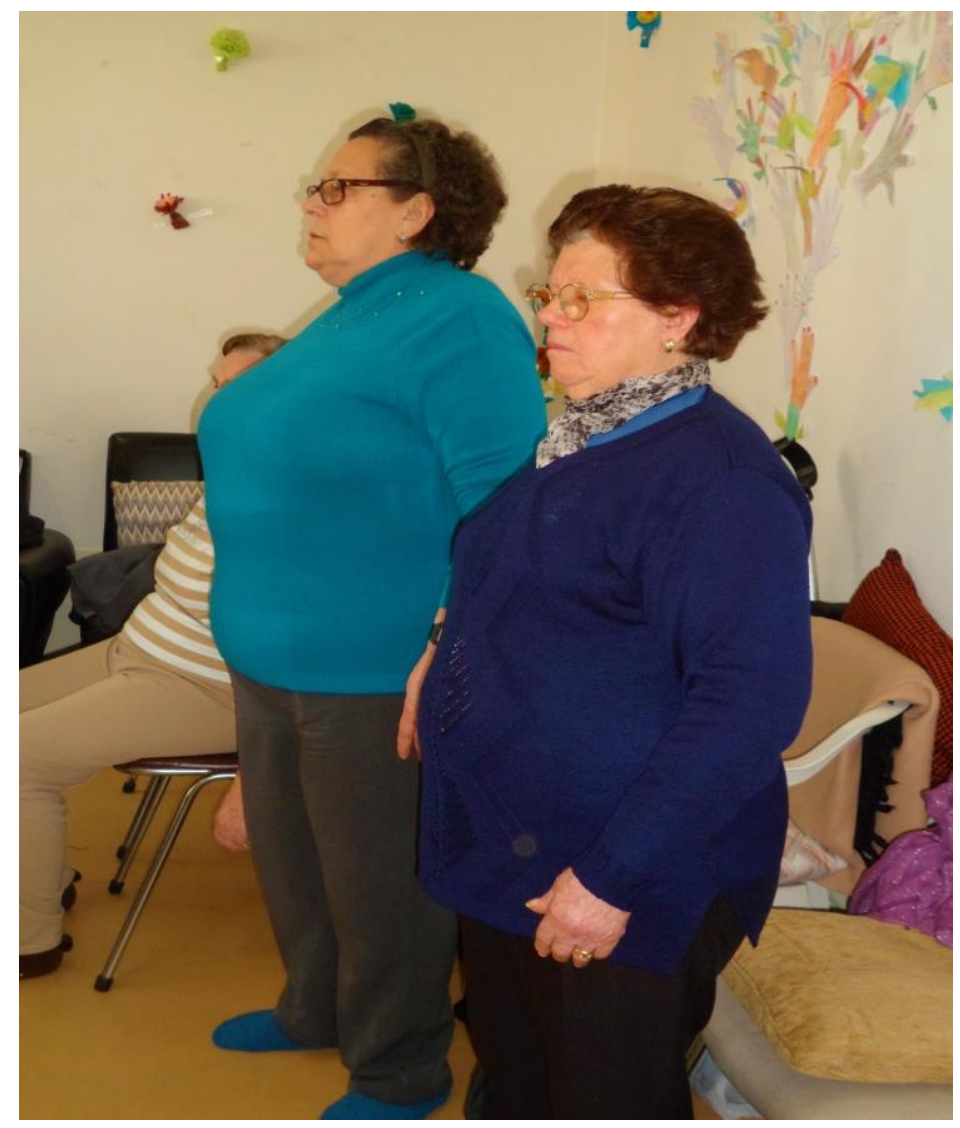

Imagem 07: Exercício de integração postural 
Foi perceptível, no seguimento das atividades de corpo, uma mudança progressiva no comportamento e nas atitudes corporais das idosas. Os procedimentos de alongamento corporal e de aquecimento muscular/articular propiciaram uma melhoria na capacidade de resistência para suportar o esforço físico e a fadiga durante o treinamento, como também uma melhoria na mobilização articular (na desenvoltura, na flexibilidade e na amplitude dos movimentos). As articulações, por exemplo, pareciam ter sido desprendidas dos "nós" que antes as retinham. Foi notório, também, o aumento da ação e dos reflexos corporais, como também da consciência da atitude vertical e dos movimentos, que se tornaram quase automáticos.

Segundo a Opas (2012), da mesma forma que o equilíbrio a flexibilidade do movimento também se encontra bastante afetada em pessoas de mais idade. Uma das principais causas da falta de flexibilidade, por exemplo, seria a ocorrência de doenças degenerativas ao nível das articulações, fazendo com que estas se tornem menos estáveis, diminuindo a mobilidade. A falta de mobilização articular em idosos geralmente é mais acentuada nos ombros e na coluna vertebral.

O ombro é a articulação mais flexível do corpo, graças á sua constituição complexa. A síndrome do "ombro doloroso" é uma importante causa de dor, limitação funcional e dependência física no idoso. Tem como causas principais as artrites, tendinites e bursites. A lesão do manguito rotador ou síndrome do impacto é a principal causa de dor e incapacidade no ombro, especialmente quando ocorre sua ruptura, parcial ou total. Sua lesão caracterizase pela presenca de dor e dificuldade de elevação e sustentação do braco afetado, em tarefas como pentear o cabelo, pendurar roupas no varal, tocar as costas, arremessar objetos, vestir-se ou despir-se, segurar objetos acima da cabeca, etc. As mãos, por sua vez, são estruturas extremamente complexas e funcionalmente decisivas para a independência do individuo. A presenca do dedo oponente ao polegar permite o "movimento de pinça", fundamental para a evolucao da espécie humana. As mãos são frequentemente acometidas nas doenças reumatológicas e podem trazer limitações importantes para o paciente, como a osteoartrie, artrite reumatóide, o dedo em "gatilho" e a sindrome do tunel do carpo. (Opas, 2012, p. 32) 
A mobilidade articular é algo que contribui para a realização das atividades regulares da vida diária. Ela é responsável pelo deslocamento do indivíduo no espaço e pela manipulação do meio, que por sua vez, depende diretamente dos membros superiores: ombros e mãos. A perda da mobilidade e a diminuição do nível de autonomia nas atividades da vida diária pode provocar no indivíduo o sentimento de fragilidade, e o resultado sempre é, na maioria dos casos, de desolação, tristeza, frustração e sentimento de inutilidade. O comprometimento das atividades domiciliares, inclusive das tarefas voltadas para o cuidado pessoal, pode ser evitado ou até mesmo revertido se o indivíduo mantiver-se participativo em programas de atividades físicas que possibilitem exercícios orientados para a mobilidade articular e para a força muscular (Opas, 2012).

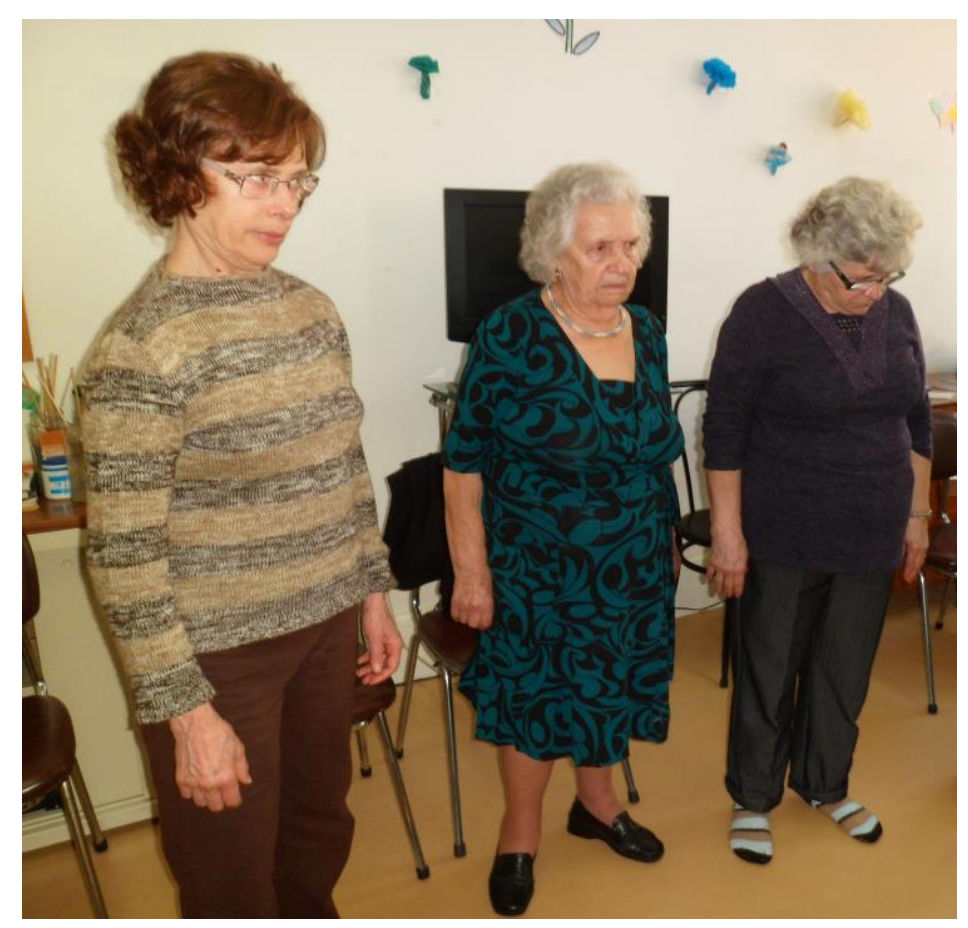

Imagem 08: Aquecimento da articulação do pescoço

Observamos que os procedimentos de massagem e relaxamento corporal foram os mais apreciados pelas idosas. Tais procedimentos promoveram 0 descanso muscular e mental, estimulando a sensação de revigoramento e de alívio muscular, reduzindo as tensões e provocando a sensação de bem-estar psicofísico.

As técnicas de integração postural (base de apoio, eixo corporal e encaixe do quadril) facultaram às idosas uma base mais segura, um eixo correto e um 
melhor equilíbrio em postura vertical, o que muito contribuiu para que elas, no decorrer do percurso prático, se mantivessem de pé por um tempo bem mais prolongado que o habitual, sem se cansarem e, com tudo isso, sem pedirem para sentar. Já os exercícios de deslocamento (transferência de peso, forma correta de caminhar), ritmo e percepção espacial, levaram as idosas a desenvolver uma melhor precisão e dinamicidade no caminhar, agora mais correto, mais seguro, com menos esforço e sem a necessidade de apoios. Segundo Berge (1975), quando o nosso corpo está harmoniosamente organizado e a eutonia muscular e a atitude postural estão corretas, não fazemos esforço e não sentimos cansaço, estamos repousados sobre o nosso eixo, estamos de pé.

Observamos que o contentamento com o desempenho pessoal e com os resultados obtidos serviram de motivação para que as idosas participassem, se envolvessem e se esforçassem a cada exercício proposto. Percebemos nas falas e nas atitudes das idosas o desejo de superar as limitações e dificuldades impostas pelo próprio corpo, como também a vontade de passar além dos desafios colocados pelos exercícios. Se no princípio as idosas duvidaram que fossem capazes de cumprir com as atividades corporais porque, segundo elas, se sentiam velhas, doente, enferrujadas, pesadas, cansadas e preguiçosas, a prática mostrou o contrário. No decorrer do processo as idosas, no seu limite, a seu modo e no seu tempo, conseguiram cumprir com os exercícios propostos. Todas elas mantiveram-se potencialmente ativas e participativas, ainda que um e outro exercício demandasse tempo esforço físico. Mais a mais, inferimos que o respeito e o cuidado com o próprio corpo foram se tornando uma preocupação cada vez mais constante. Recorto e aponto aqui 03 (três) comentários:

- Estou a mexer-me mais, que às vezes estou a muitas horas sentada e não convinha. (RR, 75 anos)

- Acho que faz bem fazer estas atividades, estas ginásticas que fazemos. O aquecimento faz bem aos músculos e ao organismo, gosto muito do que se está a aprender. (MC, 70 anos)

- Depois que ando aqui já levanto mais os braços, que já não conseguia tirar a louça da máquina pra por no móvel, cada vez vai ficando mais alto e tenho dificuldade. (...) Este braço já está melhor do que este, já está mais preso, porque agente precisa também fazer ginástica. (MS, 82 anos) 


\subsubsection{As atividades de Expressão corporal:}

Cada idoso pode e deve conservar um pouco de alegria no movimento e prazer no esforço, independentemente da idade.

Mellerowicz

De acordo com Pedrosa e Tavares (2009), a expressão corporal é uma atividade organizada, dotada não só de objetivos que visam o desenvolvimento da sensibilidade, da imaginação e da criatividade, mas principalmente da comunicação. Esta comunicação, mediante os autores, vai se dar a partir da relação que é estabelecida entre o sujeito e o próprio corpo, entre o corpo do sujeito e o corpo do outro, como também em relação à música, ao ambiente e ao mundo. Estas relações vão surgindo no momento da espontaneidade, no momento em que o sujeito atua com total liberdade. Estas relações é que mantem o sujeito no mundo da percepção - um ser aberto em relação ao meio - cuja manifestação física se dá a partir de processos perceptivos, por meio da sensibilidade, pelo campo do sentir. Em outros termos, trata-se da capacidade de experienciar no ambiente em que este corpo está se manifestando. Este seria o momento da expressão criativa, da perspectiva de diálogo e de troca, a partir do próprio corpo, a partir do movimento.

No decorrer do processo buscamos desenvolver também um conjunto de exercícios de expressão corporal, orientados para o trabalho de conscientização do corpo, sob a forma de pequenas percepções, como por exemplo: dos movimentos do corpo; dos movimentos afetivos; de espaços e planos; de ritmo e de tempo; de sensações e de estados corporais; evidenciando a liberação dos gestos e da energia, e sempre respeitando os limites corpóreos e a individualidade de cada uma das idosas participantes. Segundo Gil (2001), o trabalho de conscientização corporal não termina no corpo, ele também se abre para fora, ou seja, é um aprender sobre si mesmo e o mundo. Neste sentido, comenta o autor, é necessário tomarmos consciência do quão importante é o nosso corpo, pois ele é um "arquivo vivo" que guarda registros de toda uma vivência e sabedoria, de tudo o que vimos, ouvimos e sentimos ao longo da nossa uma vida. 
Os exercícios de expressão corporal compreenderam a apreensão e fisicalização de pensamentos, sentimentos, emoções, sensações, necessidades e desejos através do corpo, como também a livre improvisação: a partir da produção de movimentos espontâneos e aleatórios (sem pensar, sem se interrogar, lançando-se no espaço); a partir das relações propostas (corpo $\mathrm{x}$ música, corpo $\mathrm{x}$ objeto, corpo $\mathrm{x}$ espaço e corpo $\mathrm{x}$ corpo). Todos os exercícios de expressão corporal implicaram a interação, a criação, a comunicação e a desinibição corporal. Bege (1975) comenta que a expressão corporal permite que o indivíduo exprima seus sentimentos mais ocultos, suas emoções mais essenciais, como também conectar o próprio corpo, comunicar o que pensa, reencontrar o contato com a natureza e os outros. Seguem 02 exercícios:

\section{Expressão Corporal A}

Exercício do espelho (em duplas): de pé os indivíduos $\mathrm{A}$ e $\mathrm{B}$ se posicionam frente-a-frente. $O$ indivíduo $A$ cria uma sequência de movimentos a partir da relação estabelecida entre o seu corpo e a música proposta, enquanto o indivíduo B (imagem refletida no espelho) tenta reproduzir os mesmos movimentos. Ao sinal do orientador a ação é invertida.

\section{Expressão Corporal B}

Encontrar a fotografia ou escultura de cada sentimento ou estado, como por exemplo: alegria, tristeza, ira, pavor, dor, medo, preguiça, etc. Passar de um sentimento para outro automaticamente.

Todos os exercícios de expressão corporal envolveram música prazerosa e um pouco de atuação. Observamos que a música, neste contexto experiencial, foi um elemento fundamental. Enquanto estímulo sonoro integrado ao movimento, a música impulsionou a expressão corporal, de modo a incitar e conduzir o movimento, evocar e libertar sentimentos e emoções, estimular a imaginação e a criação. Segundo Berge (1975), o dinamismo melódico e rítmico da música é algo que conduz o indivíduo a uma entrega total do corpo, que é essencial para se atingir a espontaneidade gestual, ou seja, a livre expressão. 


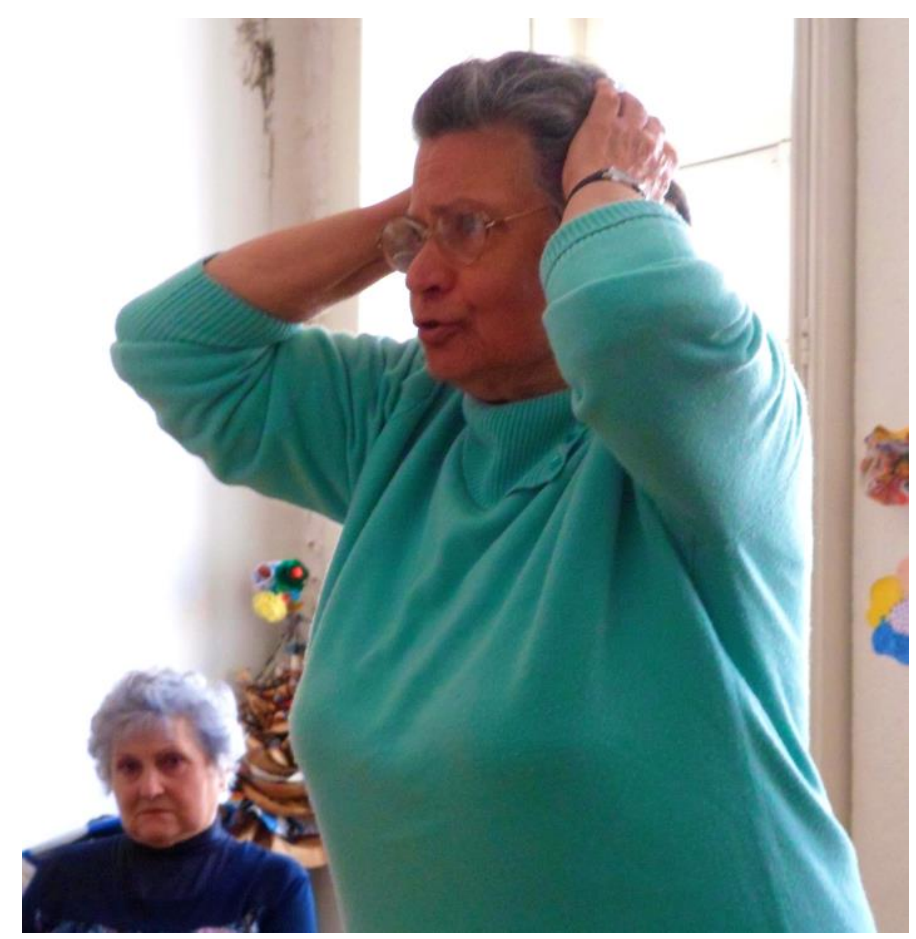

Imagem 09: Escultura de um sentimento

Nas atividades de expressão corporal a liberdade pessoal foi o substrato essencial que permitiu a criação e a presença expressiva no seu estado mais puro. Os vínculos relacionais alí já existentes, como também a coesão de grupo, contribuiram, de forma efetiva, para que a liberdade fosse logo instituída. Essa experiência real de liberdade (sem exigências, sem responsabilidades e sem opressão) foi que possibilitou a espontaneidade e a livre expressão. Esta verificação se deu, sobretudo, naqueles exercícios onde as idosas foram orientadas a fisicalizar sentimentos e emoções. Nestes exercícios os movimentos pareciam estar realmente preenchidos de verdade, isto é, justificados pela veracidade das ações, sempre carregadas de intenção, de sentimento e de emoção, dando espaço ao envolvimento, à expressão e à criação.

Observamos que os exercícios de expressão corporal também facultaram o desenvolvimento da atenção e da concentração, levando as idosas a manteremse inteiramente centradas e voltadas para o seu trabalho pessoal, sem distrações e sem medo. 


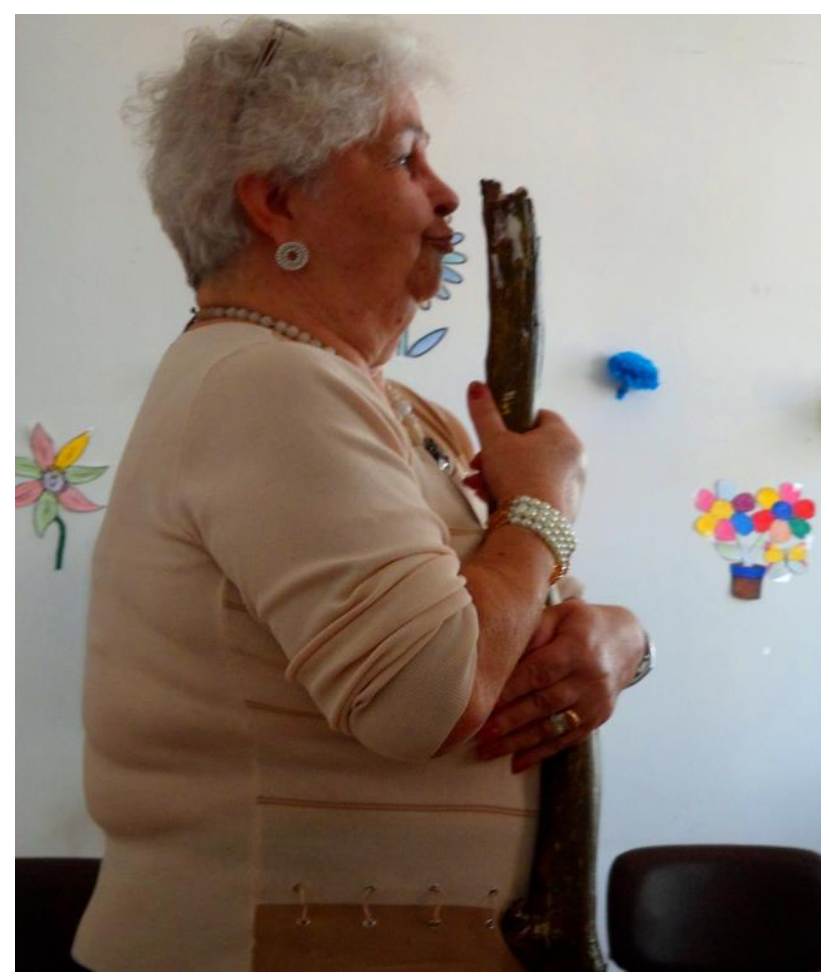

Imagem 10: Relação com objetos

A apreensão de uma base de apoio mais segura, de um eixo corporal mais correto, de um melhor equilíbrio em postura vertical, de uma melhor precisão e segurança no caminhar e de uma melhor desenvoltura, flexibilidade e amplitude nos movimentos, possibilitados nas atividades de corpo, foram cruciais para o bom andamento das atividades de expressão corporal. Todas estas conquistas permitiram que as idosas adquirissem uma maior confiança no próprio corpo, como também uma maior desinibição, liberdade e concentração para a criação. Os trabalhos de expressão corporal levaram as idosas a aprimorar ainda mais a precisão e a fluidêz dos movimentos, principalmente dos braços e da coluna vertebral. Conforme Berge (1975), quando o corpo está bem afinado: o tronco centra-se sobre o seu eixo; o quadril se torna mais dinâmico; os joelhos são capazes de flexões e impulsões dinâmicas; o desequilíbrio deixa de ser temido; os braços e as pernas, os pés e as mãos são capazes de cadências e gestos diferentes e simultâneos; os gestos se tornam mais precisos e aptos a adaptaremse a ritmos diferentes. 


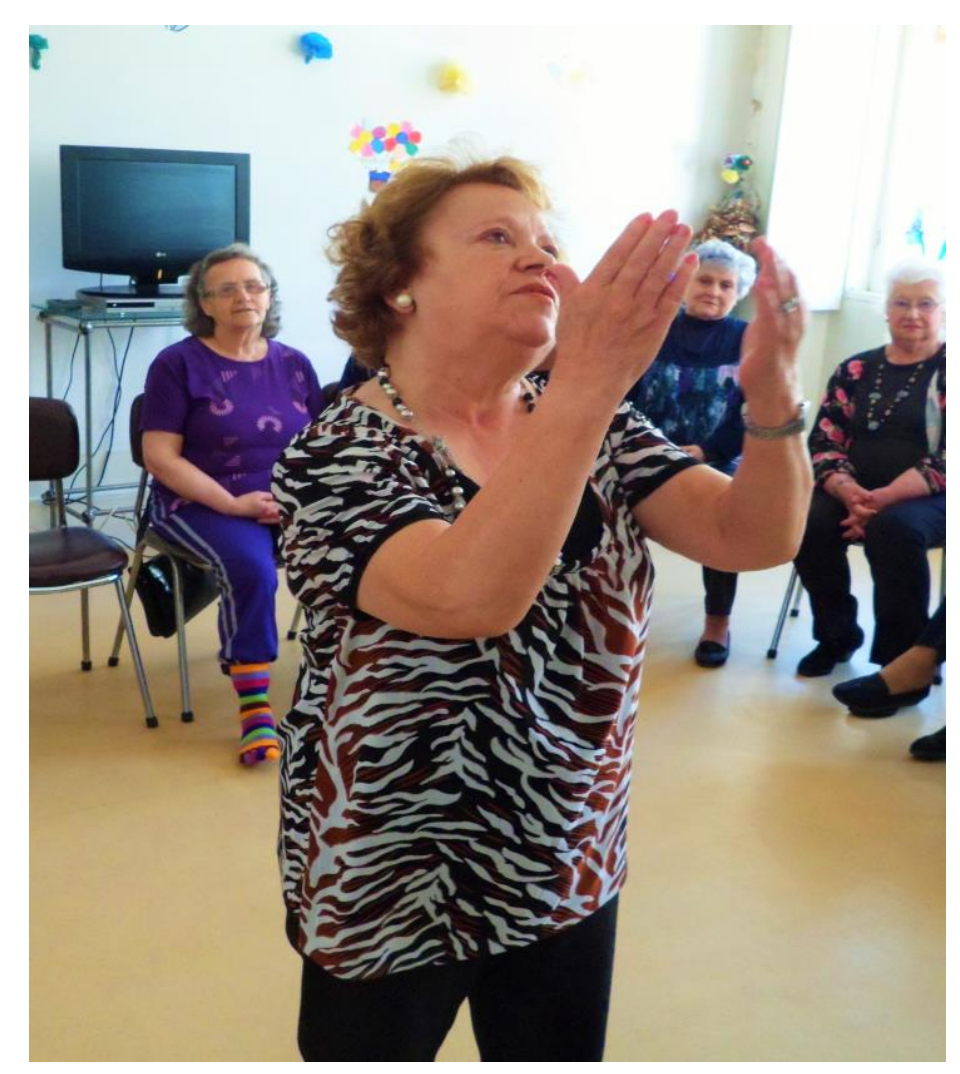

Imagem 11: Expressão de sentimentos

Inferimos que a aquisição de uma nova consciência corporal fez com que as idosas investissem ao máximo no próprio desempenho. Os exercícios corporais, a saber, constituíram um excelente meio de prover a independência e a autonomia motora. Além da dimensão motora, os exercícios corporais possibilitaram que trabalhássemos também a dimensão cognitiva, afetiva e social, que estão intimamente inter-relacionadas com o sentimento de satisfação e de realização pessoal. Segue o comentário de uma das idosas, apontado no seu diário de bordo:

- Acho que a libertação do corpo, a libertação dos gestos, dos movimentos, de tudo, o som da música, não sei, é uma libertação, uma coisa fantástica. (...) Foi mais uma tarde de muito riso, alegria e convívio saudável. É uma terapia necessária para o corpo e principalmente para a mente, da qual eu gosto muito. (MJ, 70 anos) 


\subsubsection{Os Jogos tradicionais:}

De acordo com o filósofo Huizinga (2000), o jogo é uma atividade social fundamental, um elemento lúdico, uma categoria absolutamente primária da vida. Na sua obra Homo Ludens, o referido autor aponta que o jogo é um complemento e, em última instância, uma parte integrante da vida em geral, haja vista que o jogo ornamenta e amplia a vida, tornando-se uma necessidade vital, tanto para o indivíduo quanto para a sociedade, devido ao sentido que encerra, ao seu valor expressivo, à sua significação e às suas associações sociais. Mais a mais, o jogo tem uma função biológica, do ponto de vista pessoal, e uma função cultural, do ponto de vista social e comunitário.

De uma forma simplificada e generalizada, o jogo geralmente é percebido como prática para se ocupar o tempo, como prática de lazer, como brincadeira e como diversão. Jogar é um procedimento lúdico, com fins recreativos, praticado nas horas de ócio. Trata-se de uma atividade ou de uma ocupação voluntária, livre, inútil, gostosa, repetível, dotada de um fim em si mesmo, capaz de produzir um estado de exaltação e de alegria. Jogar é uma ação que se faz possível num espaço/tempo específico, limitado, com uma organização pré-estabelecida, com regras bem específicas e obrigatórias, que impõem ordem, tensão, incerteza e alegria à ação lúdica. Segundo o referido autor, no jogo sempre existe "alguma coisa em jogo" que ultrapassa as necessidades humanas, conferindo um sentido e um significado à ação. Nos seus estudos o autor descreve as características formais do jogo da seguinte forma:

O jogo é uma atividade livre, conscientemente tomada como "séria" e exterior à vida habitual, mas ao mesmo tempo capaz de absorver o jogador de maneira intensa e total. É uma atividade desligada de todo e qualquer interesse material, com a qual não se pode obter qualquer lucro, praticada dentro de limites espaciais e temporais próprios, segundo certa ordem de regras. Promove a formação de grupos sociais com tendência a rodearem-se de segredo e sublinharem sua diferença em relação ao resto do mundo, por meio de disfarces ou outros meios semelhantes. (Huizinga, 2000, p. 13) 
Huizinga aponta ainda que o jogo não é vida corrente nem vida real, ao contrário, é uma ação lúdica que possibilita a evasão da vida real para uma esfera temporária de atividade com orientação própria, acompanhada de uma consciência de realidade secundária, ilusória, fictícia. De acordo com Cuenca (2009, p. 113), "a ação lúdica diverte quando nos adentramos na dinâmica do jogo e em sua lógica interna porque, por ser tão diferente da lógica diária, nos separa da realidade e nos liberta dela, impulsionando a capacidade criadora". Deste modo, movido pelo estado de liberdade e de êxtase proporcionado pelo jogo, o indivíduo é levado a vivenciar um mundo diferente, lúdico, imaginativo, distinto do mundo real, desenvolvendo, a partir daí, outras percepções e conhecimentos acerca de si. Mediante os referidos autores, é pelo menos assim que o jogo nos apresenta: como um intervalo em nossa vida cotidiana; como uma atividade lúdica que transcende as necessidades e os desejos; como uma atividade que se desenvolve em função da satisfação, que consiste na realização do próprio ato de jogar.

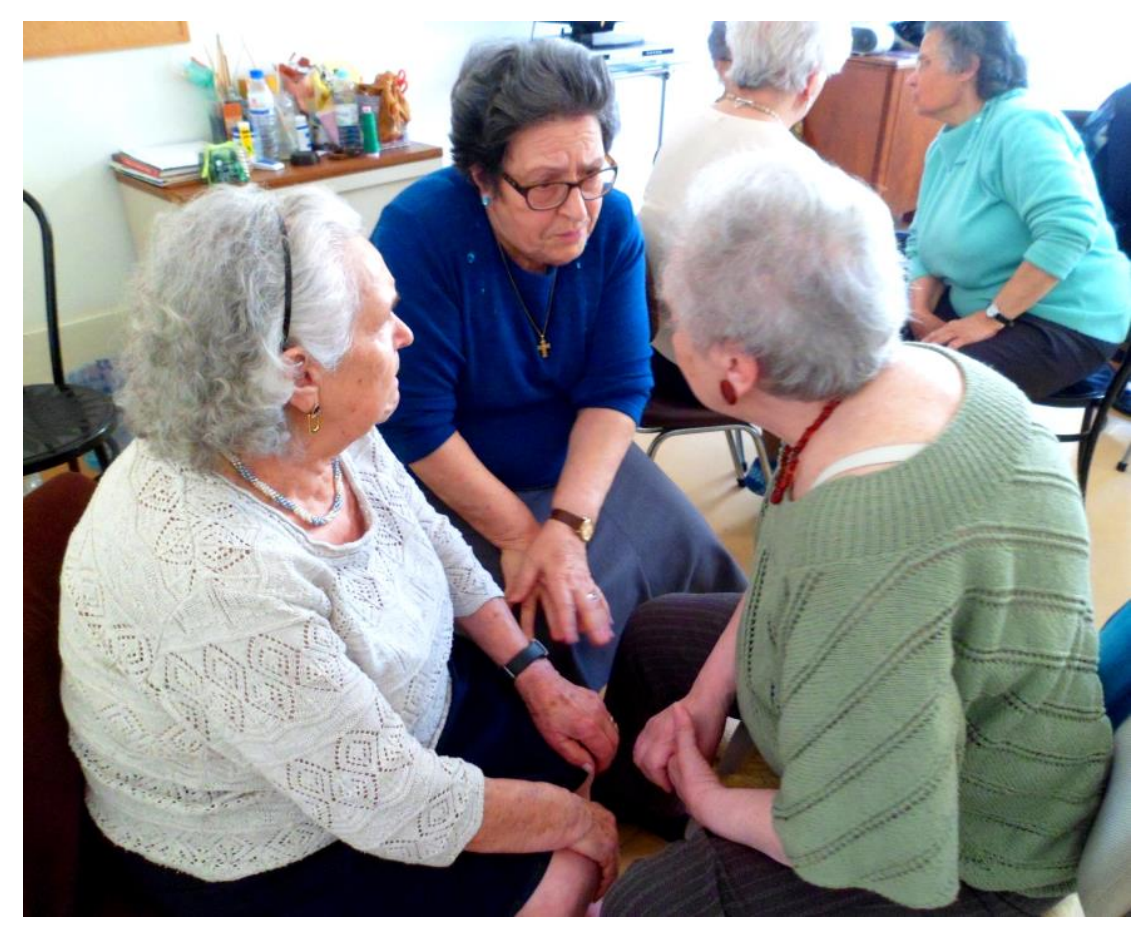

Imagem 12: Jogo do "inventar estórias"

Os jogos tradicionais são atividades, individuais ou em grupo, relacionadas com o ato de brincar, com a diversão e com a evasão. Estes jogos possuem regras específicas, objetivos, desafios que orientam, incitam e envolvem a ação 
espontânea dos jogadores, como também impõem ordem, tensão, incerteza e alegria à ação lúdica. De acordo com Huizinga (2000, p. 12), todo jogo tem suas regras, e "são estas que determinam aquilo que vale dentro do mundo temporário por ele circunscrito. As regras de todos os jogos são absolutas e não permitem discussão". Mediante Koudela (1990, pp. 47-48),

Qualquer jogo tradicional é realizado a partir de um certo número de regras, aceitas para colocá-lo em movimento. As regras estabelecidas entre os jogadores determinam uma relação de parceria, que implica observação de determinadas leis que asseguram a reciprocidade dos meios empregados para ganhar. Há, portanto, acordo de grupo sobre as regras do jogo e interação, que ocorre a partir da busca de um objetivo comum. (...) A regra estabelece uma estrutura que prefigura o parâmetro para a ação lúdica.

No decorrer do processo aplicamos uma variedade de jogos em grupo. Nestes jogos considera-se que todos os jogadores são "fazedores da ação", ou seja, todos participam do jogo. Os jogos em grupo, para além de promoverem momentos de recreação, divertimento e evasão, são percebidos como prática para estimular, aumentar e desenvolver capacidades, competências e habilidades cognitivas e adaptativas, como por exemplo, a percepção, a atenção, a concentração, a memória, o controle emocional e a linguagem, essenciais para a adequação aos jogos teatrais. De acordo com a Organização Pan-Americana da Saúde (2012, p. 26),

A cognição é um conjunto de capacidades mentais que permitem ao indivíduo compreender e resolver os problemas do cotidiano. Formada pela memória (capacidade de armazenamento de informações), função executiva (capacidade de planejamento, antecipação, sequenciamento e monitoramento de tarefas complexas), linguagem (capacidade de compreensão e expressão da linguagem oral e escrita), praxia (capacidade de executar um ato motor), gnosia/percepção (capacidade de reconhecimento de estímulos visuais, auditivos e táteis) e função visuoespacial (capacidade de localização no espaco e percepção das relações dos objetos entre si). É responsavel pela nossa capacidade de decidir. Juntamente com o humor (motivação), e fundamental para a manutenção da autonomia. 
Schneider e Irigaray (2008, p. 591) comentam que, em parte, "a caracterização do indivíduo como velho é dada quando ele começa a ter lapsos de memória, dificuldade de aprendizado e falhas de atenção, orientação e concentração, comparativamente com suas capacidades cognitivas anteriores". Num processo normal de envelhecimento algumas capacidades, como por exemplo, a memória e a concentração, diminuem naturalmente, contudo, estas capacidades, entre outras, podem ser estimuladas e desenvolvidas. Geralmente estas perdas são compensadas por ganhos em experiência, conhecimento e sabedoria.

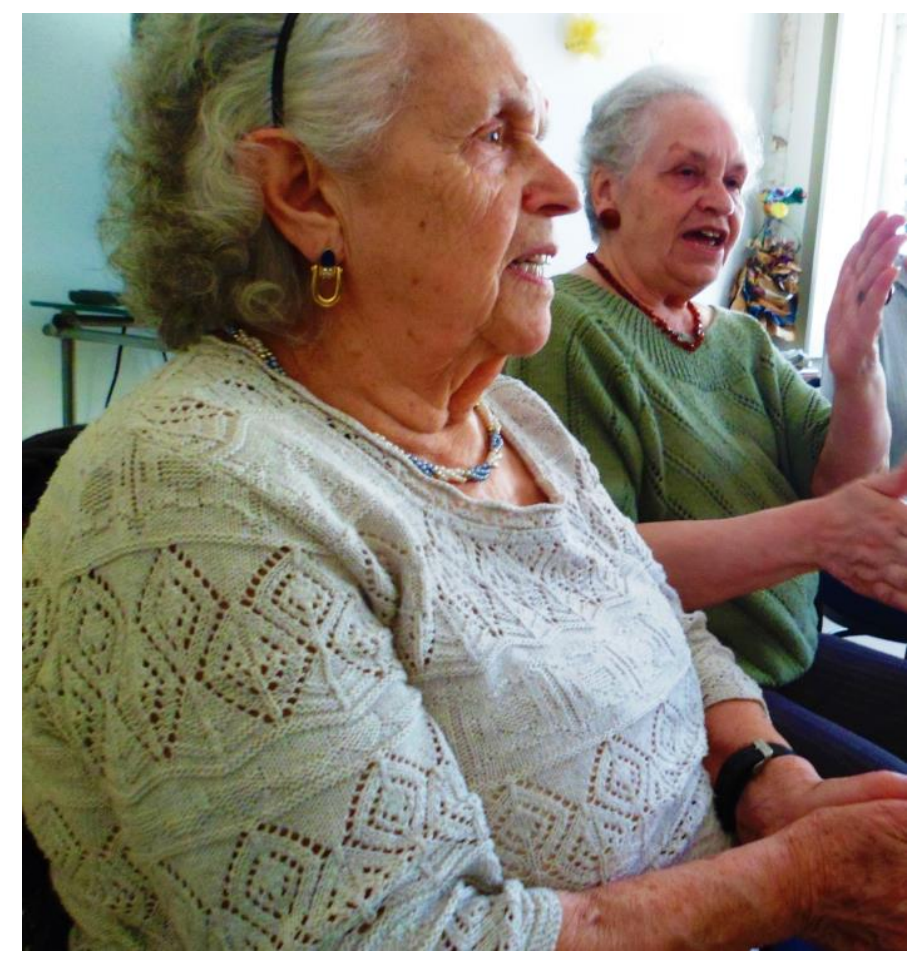

Imagem 13: Jogo das palmas

Conforme Koudela (1990), os jogos tradicionais propõem o clima e o envolvimento necessário para os jogos teatrais, enquanto recurso para estabelecer a liberação da ludicidade. Estes jogos funcionam como condutores, preparam o campo, introduzem o jogo teatral. Estes jogos geralmente são aplicados antes dos jogos teatrais, como forma de encontro e aquecimento. A função mais importante que estes jogos cumprem é o princípio através do qual é gerado a confiança necessária para jogar o jogo. "Quando o indivíduo percebe que não existe imposição de modelos ou critérios de julgamento e que o esquema 
é claro, ele deixa de lado o medo de se expor (subjetivismo) e participa da ação conjunta" (Koudela, 1990, p. 48). Seguem como exemplo 02 jogos orientados ao grupo:

\section{Jogo do pato}

O jogador A (segurando um pato de borracha na mão) diz para o jogador $B$ : aqui vai o pato (passa o pato para o jogador $B$ ). $O$ jogador $B$ se volta para 0 jogador $A$ e pergunta: o quê? $O$ jogador $A$ responde: o pato. $O$ jogador $B$ (segurando o pato) diz para o jogador C: aqui vai o pato (passa o pato para o jogador $\mathrm{C}$ ). $\mathrm{O}$ jogador $\mathrm{C}$ pergunta para o jogador $\mathrm{B}$ : o que? $\mathrm{O}$ jogador $\mathrm{B}$ se volta novamente para o jogador $A$ e pergunta: o que? $O$ jogador $A$ responde: 0 pato. $O$ jogador $B$ responde para $O$ jogador $C$ : $O$ pato. $E$ assim sucessivamente. Todas as perguntas devem chegar até o jogador A.

\section{Jogo do maestro}

Um jogador sai da sala enquanto o grupo escolhe um líder (maestro) para fazer os movimentos. O jogador é então chamado de volta e colocado no centro do círculo. $O$ jogador vai tentar descobrir quem é o maestro, cuja função é propor movimentos (bater palmas, acenar, saltar, etc.). Todo o grupo imita os movimentos do maestro e tentam evitar que o jogador do centro identifique o maestro.

Observamos que as idosas não demonstraram nenhuma dificuldade em perceber o funcionamento dos jogos, muito menos as regras impostas por cada um deles.

Inferimos que a prescrição e a dinamicidade dos jogos tradicionais incitaram a mente e o corpo das idosas, contribuindo para o desenvolvimento das faculdades cognitivas (percepção, atenção, concentração, linguagem, raciocínio, imaginação, memória), das habilidades manipulativas (lançar, receber, rebater, agarrar objetos) e das habilidades rítmicas (coordenação, sincronia, memorização, repetição de movimentos).

A competição e os desafios impostos nos jogos tradicionais serviram de motivação para o jogo. Determinadas em vencer no jogo, as idosas buscaram valer-se da sua própria experiência, competência, eficácia, conhecimento e 
vivência pessoal, para responder aos desafios e imprevistos. Por outro lado, o sentido de cooperação entre as idosas ajudou a estabelecer o equilíbrio e o senso de democratização nos jogos, ou seja, ao mesmo tempo em que as idosas desejavam vencer no jogo, elas também buscavam facilitar a ação das colegas, para que elas continuassem a jogar e a se divertir. $O$ senso de cooperação possibilitou a participação contínua, levando as idosas a experimentar a satisfação de jogarem e de se divertirem juntas.

Os jogos tradicionais facultaram a brincadeira, a diversão e a vivência da alegria, que consistiram na realização e no prazer do próprio ato de jogar. Foi na intensidade dos jogos, no seu poder de fascinação, excitação e exaltação que a brincadeira, o divertimento e a alegria emergiram. Mais a mais, a cada jogo proposto as idosas foram se mostrando cada vez mais livres, mais imaginativas, mais atentas, mais concentradas, mais seguras, mais capazes e mais confiantes em si mesmas.

Segundo Huizinga (2000), os adultos também encontram imenso prazer no ato de jogar, jogam porque gostam de brincar, e é precisamente em tal fato que reside a liberdade. Já o divertimento e a alegria, estes são a essência do jogo. Conforme o referido autor, "mesmo depois de o jogo ter chegado ao fim, ele permanece como uma criação nova do espírito, um tesouro a ser conservado pela memória. É transmitido, torna-se tradição. Pode ser repetido a qualquer momento" (Huizinga, 2000, p. 11). Aponto a seguir alguns comentários:

- Essa brincadeira alegra-nos, é muito boa pra cabeça, eu tenho estado muito esquecida ultimamente. (AS, 75 anos)

- Esse tipo de atividade ajuda-nos a melhorar a cabeça, e rimo-nos muito também, é muito divertido. (MB, 77 anos)

- Jogos de memória e destreza é sempre agradável. Já tinha me esquecido de como é bom brincar. (MM, 88 anos)

- Numa brincadeira como esta nós temos que ser espertas, não é, temos que pensar rápido, agir rápido, e isso é muito bom. (FC, 80 anos)

- Não consigo perceber muito bem no início, causa-me uma certa confusão, mas depois que aprendo a brincadeira, pronto, fico mais concentrada, não é. (LV, 77 anos)

- Tarde muito divertida, cheia de invenções e brincadeiras. Realmente, parece que voltamos a ser crianças. É bom brincar. (MJ, 70 anos) 


\subsubsection{Os Jogos teatrais:}

Hora de "clownear", ou seja, de jogar, brincar, interagir, comunicar, trocar, divertir. De acordo com Kleber (2012), o termo "clownear" traduz a maneira de comportar, agir e reagir do clown, suas atitudes e ações, motivadas pelo jogo, pela brincadeira, pela diversão, e se apresenta como um importante fundamento na sua elaboração. O referido autor aponta que o clown é uma figura cômica que joga o tempo todo, sua atuação, sua diversão e sua alegria estão inteiramente ligadas a qualquer "coisa brincante", haja vista que o clown é um ser impulsionado pelo prazer de brincar, pelo prazer de se divertir, pelo prazer de promover o riso, pelo prazer de simplesmente ser.

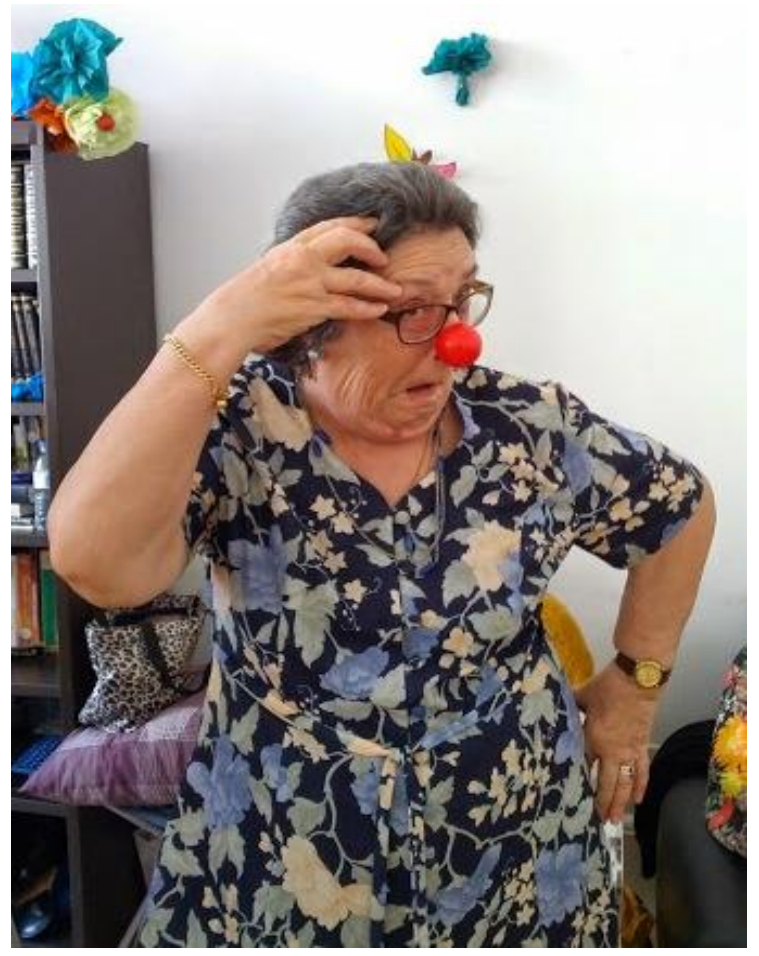

Imagem 14: Jogo teatral

No decorrer do processo as idosas foram convidadas para experienciar o trabalho do clown numa situação de representação, por meio dos jogos teatrais. Estes jogos, bem mais complexos que os jogos tradicionais, são uma designação dos jogos improvisacionais, acrescidos de uma estrutura dramática. Os jogos teatrais foram desenvolvidos pela pedagoga do teatro Viola Spolin, que ao fomentar a ideia da possibilidade do teatro fora do palco construiu uma pedagogia 
baseada na prática e na vivência de jogos, cuja metodologia está fundamentada na experiência, no ambiente da experimentação, na incorporação e na comunicação. A vitalidade destes jogos, que são também interativos, cooperativos e divertidos, está no processo criativo do próprio ato de jogar. Nos jogos teatrais a situação do palco é que vai possibilitar ao jogador experimentar um outro modo de estar e de interagir com 0 ambiente; desenvolver sua potencialidade expressiva e perceptiva; aumentar a sua capacidade de pergunta e resposta; estender a sua habilidade de jogo e improvisação. Conforme Koudela (1990, p. 78), o teatro "trabalha o potencial que todas as pessoas possuem, transformando esse recurso natural em um processo consciente de expressão e comunicação. A representação ativa integra processos individuais, possibilitando a ampliação do conhecimento da realidade".

Conforme a pedagogia desenvolvida por Spolin (2005), nos jogos teatrais a realidade do palco é erigida a partir de uma estrutura dramática operacional muito simples. Esta estrutura está fundamentada no ONDE (o ambiente da cena, lugar onde se passa a ação), no QUEM (o personagem dentro do onde), no O QUÊ (a ação, a atividade mútua entre os jogadores). A combinatória destes três eixos (ONDE, QUEM e O QUE), tendo como regra o $\mathrm{FOCO}^{77}$ (meio de se chegar ao objetivo), é que possibilita a experiência das convenções da improvisação teatral e de suas técnicas na forma de vivência de "jogos de teatro", construindo os vários jogos possíveis, com graus de dificuldades e complexidades diversos, além de favorecer a construção de outros jogos similares.

Nos jogos teatrais a livre improvisação é que vai qualificar o jogador no que diz respeito à percepção, à ação, à espontaneidade e ao jogo, desenvolvendo nele o sentido de atenção, presença e cumplicidade para responder às eventuais manifestações que sucedem em determinados momentos. Segundo Boal (1978, p. 98), no ato da improvisação os participantes "devem aceitar como verdadeiros os dados oferecidos pelos outros durante a improvisação. Deve-se procurar completar a improvisação com novos dados que os companheiros vão inventando".

\footnotetext{
77 Cada jogo é construído a partir de um FOCO específico, ou ponto de concentração, desenvolvido a partir de instruções e regras. Sua base é a experiência prática e social do grupo e do jogador, onde são "fisicalizadas" as possíveis experiências. Busca-se, assim, desenvolver uma forma de prática teatral que não seja elaborada apenas na mente do jogador, mas por sua vivência improvisacional (Spolin, 2005).
} 
Consoante Machado (2005), seja como forma de expressão intuitiva, espontânea ou como recurso de criação, a improvisação é uma abertura que vai possibilitar ao jogador a inter-relação com o outro, entenda-se este outro os parceiros, os objetos, o cenário, a música, a plateia, os imprevistos e previstos ocorridos na cena e a própria linguagem teatral. Estas inter-relações, construídas com estes "outros" no jogo, é que estimulam o jogador em cena, permitindo-o alargar a sua capacidade de expressão e ultrapassar os limites do seu próprio ser, como também [re] inventar e [re] significar suas possibilidades de criação, que vão surgir dos acontecimentos imediatos e da sua capacidade de resposta. Segundo a referida autora, "na improvisação o que está em jogo não é a repetição mecânica da linguagem constituída, mas a dinâmica das relações, dos signos corporais na interação e comunicação entre corpo e ambiente" (Machado, 2005, p. 58).

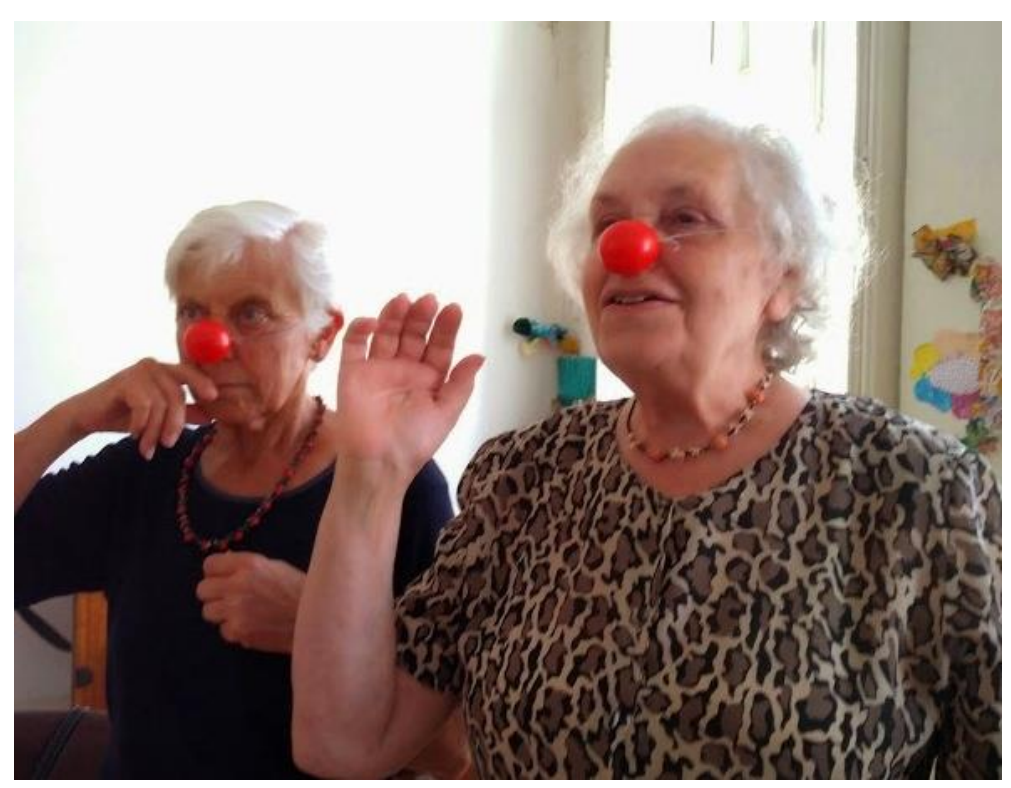

Imagem 15: Jogo teatral

Spolin (2005) comenta que ao improvisar os jogadores também são levados a experimentar o despertar da natureza intuitiva, que vai demandar de um ambiente no qual a experiência possa acontecer, de uma pessoa livre para experienciar e de uma atividade que faça a espontaneidade sobrevir. $O$ conhecimento intuitivo é algo que reage ao imediato, ao aqui e agora. Este conhecimento vai surgir no momento da espontaneidade, no momento em que 0 jogador atua com total liberdade, é o momento da descoberta, da criatividade. 
Num processo de criação do clown este enfoque é fundamental, pois a habilidade para a improvisação é algo que reflete na atuação do clown. Suas atitudes e comportamentos são caracterizados pela ação/reação natural em interação com o meio, num gesto de abertura e conectividade, de forma livre, espontânea e rápida, através do seu modo de estar e de se relacionar com o outro, seja este "outro" os demais clowns, o espaço físico, o cenário, o figurino, os objetos cênicos, a música, a plateia, os jogos estabelecidos, as situações dramáticas. Neste jogo de pergunta $x$ resposta o mais importante para o clown é o prazer de estar em cena, o prazer de se divertir com a plateia.

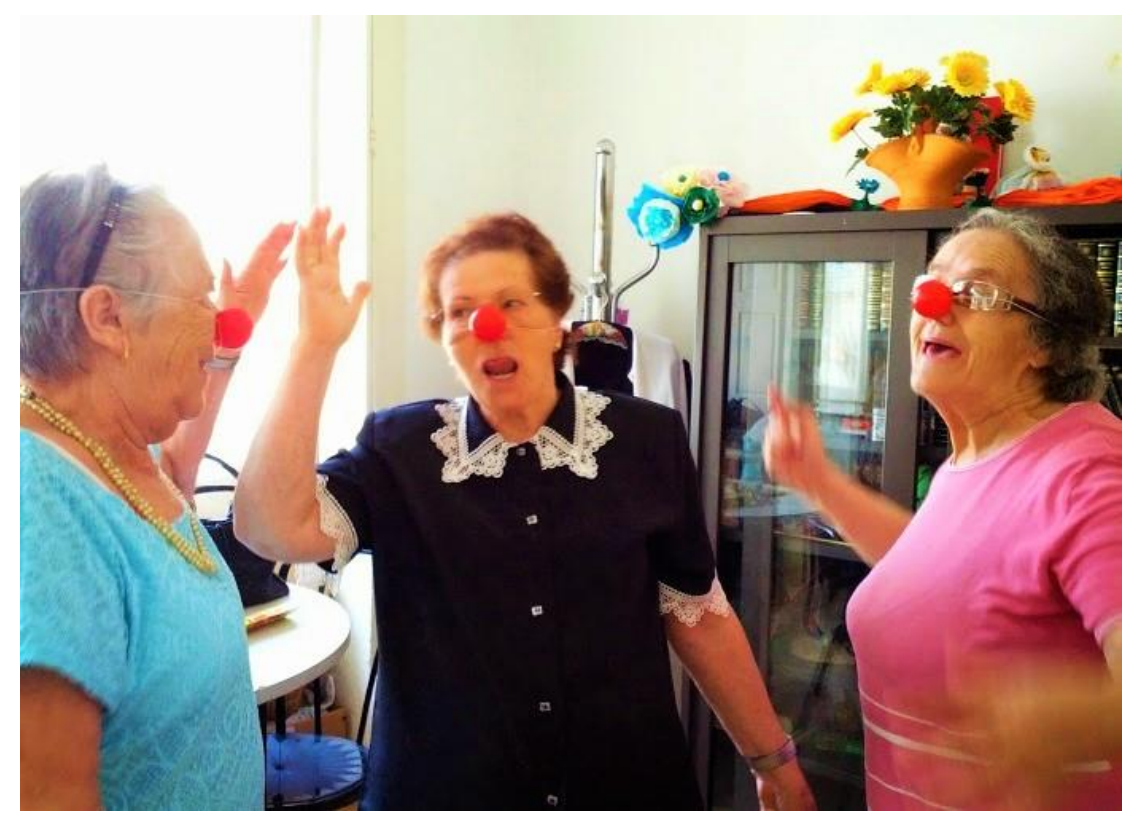

Imagem 16: Jogo teatral

Outro elemento de suma importância nos jogos teatrais, segundo Spolin (2005), é a liberdade pessoal. A liberdade é que vai favorecer a abertura para o jogo, motivar a atividade, possibilitar o comportamento espontâneo e o envolvimento necessário para a experiência teatral. Koudela (1990, p. 43) aponta que:

Por meio do envolvimento, criado pela relação de jogo, o participante desenvolve liberdade pessoal dentro do limite de regras estabelecidas e cria técnicas e habilidades pessoais necessárias para o jogo. À medida que interioriza essas habilidades e essa liberdade ou espontaneidade ele se transforma em um jogador criativo. 
De acordo com Spolin (2005), nos jogos teatrais o que muitas vezes é percebido como um "comportamento talentoso" é simplesmente uma maior liberdade ou desenvoltura que alguns jogadores apresentam para o jogo. $\mathrm{Na}$ verdade, qualquer pessoa pode jogar, qualquer pessoa pode passar pela experiência teatral, qualquer pessoa é plenamente capaz de utilizar a linguagem artística do teatro e expressar-se através dela. É através do jogo, ou seja, no momento em que a pessoa está recebendo toda a estimulação que o jogo tem para oferecer, que as habilidades necessárias para o jogo em si são desenvolvidas. "Dessa experiência integrada, surge o indivíduo total dentro do ambiente total, e aparece o apoio e a confiança que permite ao indivíduo abrir-se e desenvolver qualquer habilidade necessária para a comunicação dentro do jogo" (Spolin, 2005, pp. 5-6).

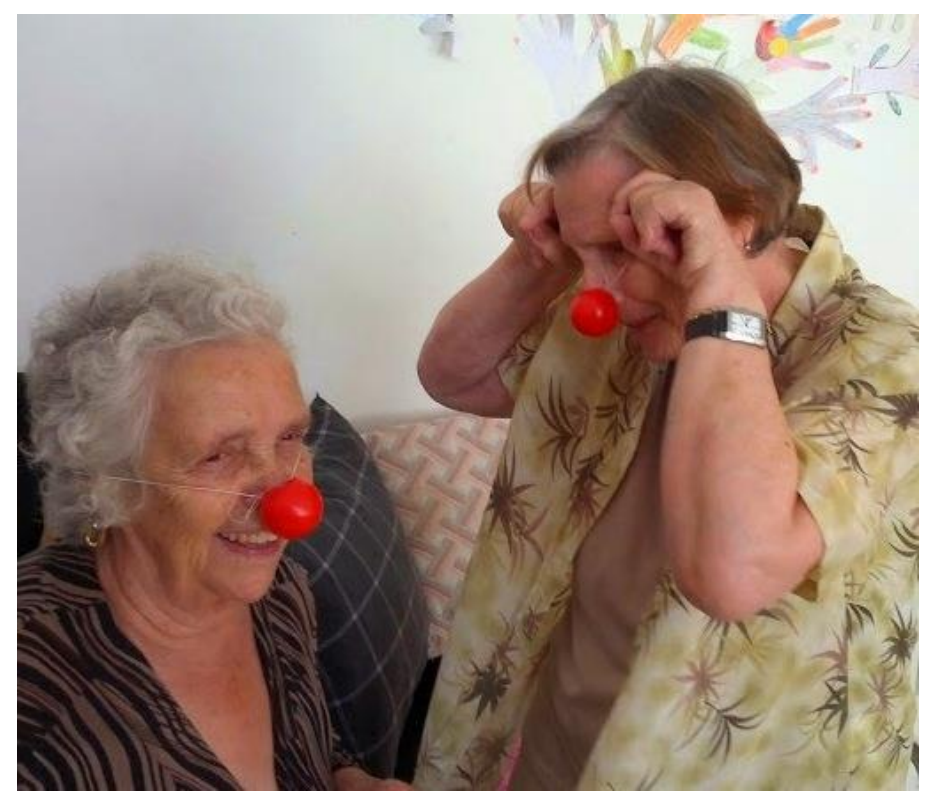

Imagem 17: Jogo teatral

Nos jogos teatrais a plateia seria um outro elemento de suma importância para a concretização do jogo. A autora supracitada aponta que a plateia, que geralmente é formada pelo próprio grupo de trabalho, deve se tornar parte concreta e orgânica do jogo, deve estar inteiramente envolvida e conectada com o jogo, fazer parte da experiência. A presença da plateia estimula o jogador em jogo, já que agrega ao seu trabalho de improvisação todos os estímulos e incidentes advindos dela, colocando-o numa dinâmica de ação $x$ reação em relação a ela. Conforme a autora, quando um jogador compreende a plateia e 
passa a vê-la não como julgadora, mas como um grupo composto por pessoas diferenciadas e com as quais ele está trocando experiência, ele adquire maior confiança em si próprio, como também obtem maior liberdade e relaxamento no palco. Segundo Kleber (2012), uma das possibilidades de jogo do clown encontrase justamente na constituição e no aproveitamento do contato com a plateia. $A$ manifestação do clown muitas vezes sustentada por esta relação, uma vez que o seu jogo se valida do confronto direto com ela.

Ao explicarmos para as idosas a estrutura operacional dos jogos teatrais (ONDE, QUEM e O QUE) e o seu funcionamento, buscamos também apontar e esclarecer alguns principios que regem a prática teatral, como por exemplo: os elementos que caracterizam a cena (delimitação do espaço físico, cenário, entradas e saídas, posicionamento no palco); a relação com a plateia (ator $x$ espectador, fazedor da ação x observador); a expressividade corporal (sensações e estados corporais); os fundamentos da técnica de improvisação (liberdade, espontaneidade, inter-relação, desenvolvimento, ruptura).

No que se refere ao QUEM (o personagem) buscamos deixar claro que na condição de clown as idosas estariam livres para improvisar/representar os personagens que quisessem, haja vista que o clown, como já foi mencionado, não é o personagem, mas o "ser" que habita aquele que o desempenha. Como bem aponta Federici (2004, p. 125), constituído de uma personalidade própria o clown pode representar todos os tipos sociais que quiser, "pois veste, acima de tudo, não um tipo específico e rígido, mas o estereótipo da troça, de si mesmo e de todos ao mesmo tempo". Seguem 02 exemplos de jogos teatrais orientados ao grupo:

\section{Blablação}

Quem: um clown

Onde: numa praça

O quê: vendendo um produto qualquer

Foco: comunicar com o público em blablação.

Instrução: olhar diretamente para o público/ apresentar o produto/ demonstrar como se utiliza o produto/ convidar alguém do público para testar o produto/ convencer o público a comprar o produto. O clown deve ser convincente. 


\section{Criar cena com objetos}

Quem: um clown

Onde: interior de uma loja de artigos usados

O quê: escolhendo um artigo

Foco: criar uma relação com o objeto que lhe chamou a atenção

Instrução: utilizar o objeto/ dialogar com o objeto/ cantar para o objeto/ dançar com o objeto/ dançar para o objeto.

Alguns exercícios considerados clássicos de clown também foram inseridos no "Sistema de atividades". Conjugados com os jogos teatrais estes exercícios ajudaram as idosas a melhor articular as suas ações espontâneas e a enriquecer ainda mais os seus jogos de cena, além de possibilitá-las uma maior proximidade e intimidade com o clown. Podemos citar, como exemplo, os seguintes exercícios: o nariz vermelho; estímulos escatológicos, imagéticos e emotivos; o olhar do clown; triangulação; situações; mímica e gags. Segue como exemplo 01 exercício clássico de clown orientado ao grupo:

\section{O olhar do clown}

Explorar o movimento dos olhos (olhar para cima, para baixo, para a direita, para a esquerda, movimento giratório, movimentar as pálpebras, movimentar os músculos da face). Perceber as sensações, expressões e imagens que cada movimento produz. Em seguida, buscar um olhar expressivo, vazio, irritado, vivo, ingênuo, curioso, sonolento, triste, medroso, preguiçoso. Criar uma máscara facial. Exagerar na expressão.

Observamos que as idosas não apresentaram grande dificuldade em entender a estrutura operacional dos jogos teatrais (ONDE, QUEM e O QUE), como também o seu funcionamento.

Improvisando sozinhas, em duplas ou trios, e sempre munidas do nariz vermelho do clown, as idosas trouxeram para a cena múltiplos personagens (mãe, vendedora, alcoviteira, atleta, cozinheira, feiticeira, professora, freira, rendeira, dançarina, agricultora, cantora, costureira, médica, rezadeira, cabeleireira, etc.); como também situações corriqueiras do cotidiano (fazer faxina, fazer compras no 
supermercado, cozinhar, passear com o cão, dialogar com a vizinha, ir ao salão de beleza, cuidar de crianças, etc.) e desejos (voltar para a aldeia, passear em Paris, dançar para muita gente, ficar rica, ir ao Brasil, conhecer o fadista Camané, etc.). Alguns clowns eram patéticos, enquanto outros eram sérios, alegres, chorões, irados, tristes, medrosos, tímidos, risonhos ou desconfiados. Alguns clowns eram pachorrentos, ao ponto que outros se mostravam mais ligeiros e desembaraçados. Houve também aqueles clowns que sentiam dor de barriga, como também aqueles que peidavam ou arrotavam em cena.

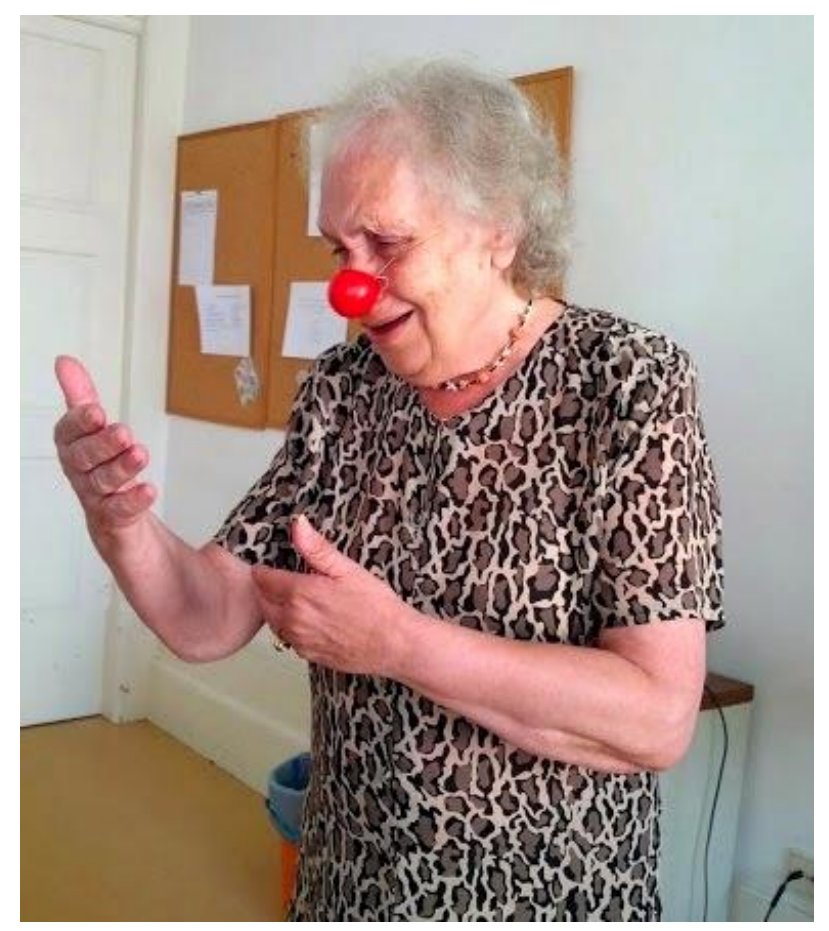

Imagem 18: Jogo teatral

De acordo com Burnier (2001) e Ferracini (2003), o clown é desenvolvido a partir do perfil individual daquele que o vivencia, ou seja, a partir do confronto entre a máscara estereotipada que esconde a pessoa do sujeito e a essência do seu próprio ser. Construir um clown é colocar-se "face a face" consigo próprio, com a sua imperfeição, com o seu lado patético e ridículo de ser, tão bem camuflados. Trata-se de um processo que compreende uma busca inquietante e dolorosa de desconstrução de si, como também aspectos relacionados à abertura, à leveza, à ingenuidade, à fragilidade e à vulnerabilidade, extremamente necessários para se atingir a espontaneidade e a alegria de um clown. Neste processo o sujeito é levado a se expor, a se permitir a todos os riscos, a aceitar o 
seu fracasso e a sua imperfeição, a reconhecer a sua comicidade pessoal, 0 risível de si mesmo e o seu ritmo próprio de ação e reação. Segundo Machado (2005, p. 11), este processo "constitui o embrenhar-se em um estado diferenciado de percepção, no qual outras potencialidades de sentimento, sensação, movimento, imagem, pensamento, ideia e ação poderão manifestar-se".

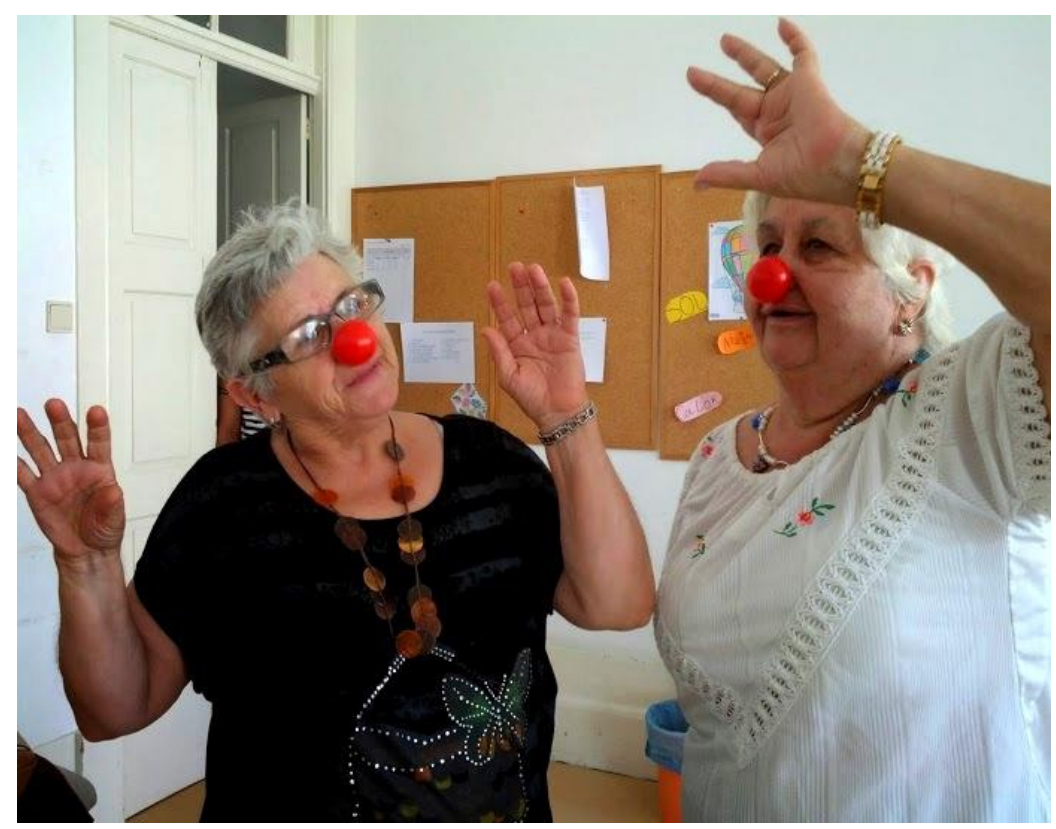

Imagem 19: Jogo teatral

No contexto da prática observamos que o nariz vermelho ${ }^{78}$ foi o "trampolim" que possibilitou às idosas mergulhar no universo lúdico e fantasioso do clown, além de estimular o jogo, a brincadeira, a diversão e a criação. Observamos que o nariz vermelho foi o "dispositivo" que também deu suporte e substancializou a atuação das idosas, concedendo a elas uma atitude de liberdade, naturalidade e espontaneidade no seu estado mais puro, voltada para o prazer de jogar, para o prazer de brincar, para o prazer de se divertir, para o prazer de rir, além da percepção de um outro modo de ser, estar, agir e relacionar com o mundo à sua volta. Nos seus estudos Burnier (2001) aponta que usar o nariz vermelho do clown é buscar um diálogo consigo mesmo e com o outro, um diálogo entre a voz de si e a voz do mundo, um diálogo entre o universo interior e os estímulos vindos

\footnotetext{
${ }^{78} \mathrm{O}$ nariz vermelho é uma representação simbólica, um signo de identificação, um sinal indicativo, capaz de revelar ao público que estes estão à frente de um clown. Tanto a máscara como as vestimentas, maquiagem e deformações físicas, como barrigas exageradas, grandes glúteos e pés escomunais, são elementos importantes na composição de um clown, constituindo um disfarce para o risível (Kleber, 2012).
} 
de fora. Conforme o referido autor, esta forma particular de se inter-relacionar com o mundo é que aos poucos determina a lógica do clown, como também a sua personalidade.

Foi notória a mudança no comportamento e nas atitudes das idosas ao colocarem o nariz vermelho do clown. Foi como se um mecanismo interno tivesse sido acionado, como se a criança interior tivesse sido despertada. Bastava que uma delas partisse para a cena com um andar meio desajeitado e uma expressão um pouco mais exagerada e, pronto, já se ouvia sonoras gargalhadas da plateia. Segundo Viveiros de Castro (2005), o nariz vermelho do clown é algo que atrai facilmente o espírito cômico da plateia, que já se mostra influenciada pelo simples entendimento de saber que está à frente de um "sacerdote da besteira". Mediante a referida autora, o clown não precisa contar uma história engraçada, ele já é a graça em pessoa, ele é o risível. Munido do seu "nariz de bolota" o clown é capaz de nos colocar num estado de suspensão e tensão que, em segundos, sabemos de antemão, vamos explodir em risos.

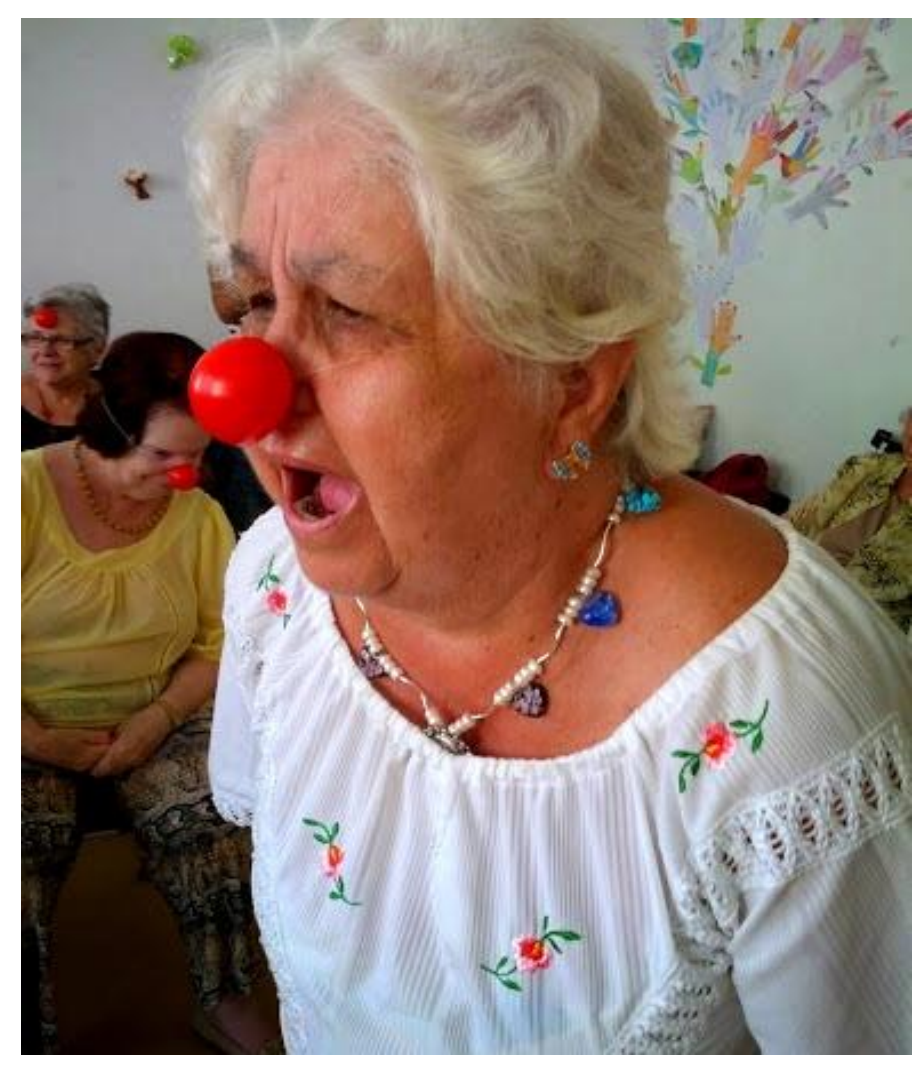

Imagem 20: Jogo teatral 
Nos jogos teatrais as idosas riam da ousadia ou da timidez como um e outro clown se apresentava em cena, da idiotice ou do modo ridículo como um e outro clown se portava em cena, como também das situações fortuitas e inusitadas, das zombarias, das chacotas e dos erros e incidentes ocorridos no momento da improvisação. Segundo Matos (2009), o riso da plateia muitas das vezes é resultado do sentimento de superioridade que ela apresenta em relação àquelas situações às quais o clown não consegue se adaptar. Estas situações, por sua vez, se revertem quando se transformam num "espelho" capaz de refletir no espectador a sua própria imagem, levando-o a entrar em contato com aspectos do risível de si mesmo, a reconhecer em si a sua imperfeição, a sua estupidez e a sua vulnerabilidade. Este fenômeno sempre ocorre quando o espectador identifica na ação do clown a incidência do humano em condições semelhantes à sua. Neste sentido, segundo a referida autora, o riso pode ser também percebido como uma forma de autocompreensão, como algo que possibilita ao ser humano compreender-se, afinal, rir do outro é também rir um pouco de si próprio.

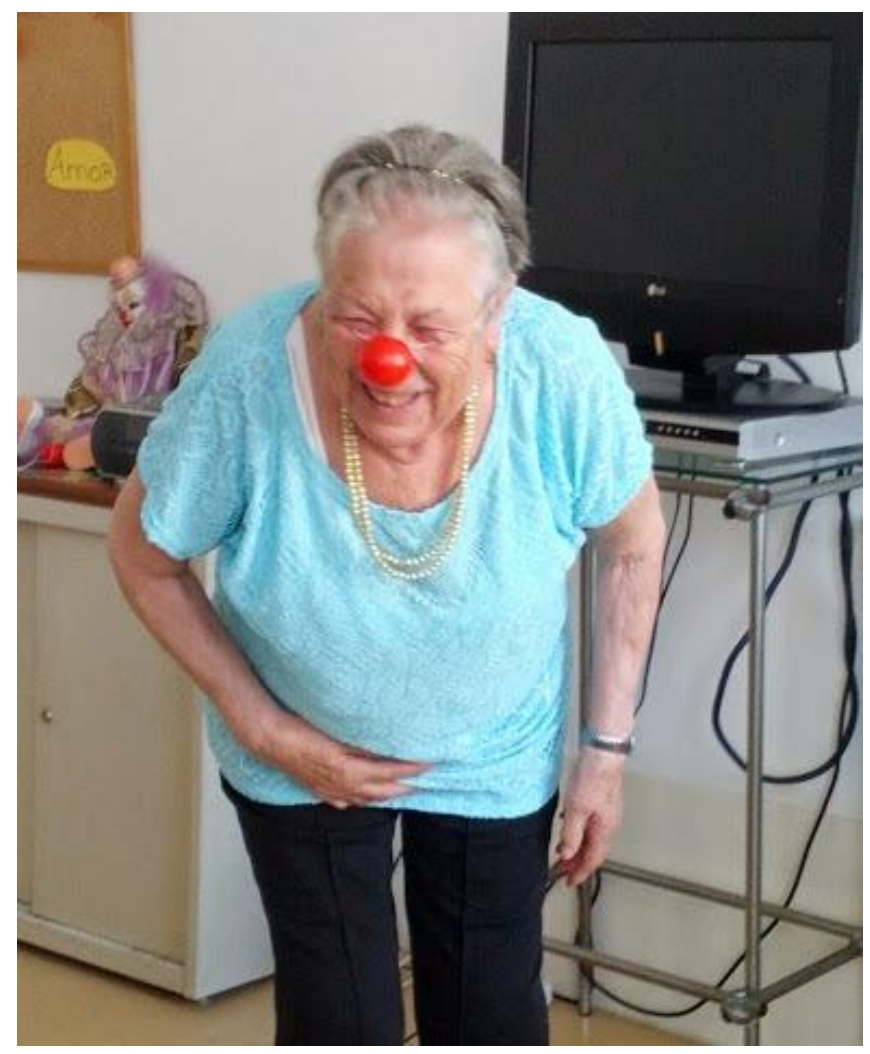

Imagem 21: Jogo teatral 
Conectar o clown também possibilitou às idosas uma primeira vivência da utilização cômica do corpo, que foi particular para cada uma delas. De forma livre, natural e espontânea, as idosas produziram movimentos exagerados, caricaturescos, carregados de comicidade. Machado (2005) comenta que num processo de construção do clown é sempre interessante observarmos as mudanças físicas que a máscara implica e traz. O nariz vermelho do clown, automaticamente, faz com que os movimentos do sujeito pareçam consideravelmente exagerados, dilatados, exacerbados, da mesma forma como ele também exagera na expressão dos seus sentimentos, das suas emoções, das suas imperfeições, dos seus erros. Observamos que esta primeira vivência da utilização cômica do corpo, a partir da experienciação com a máscara do clown, levou as idosas a experimentar o emergir de outras formas de ser, estar e fazer até antes não acessadas, como também a experimentar a sensação de que tudo Ihes é permitido.

No desenvolver dos jogos teatrais observamos que a técnica de improvisação, enquanto modo de ação e forma de expressão momentânea, qualificou as idosas no que diz respeito à percepção, à ação, à espontaneidade $\mathrm{e}$ ao jogo, desenvolvendo nelas o sentido de atenção, de presença e de cumplicidade. A improvisação possibilitou que as idosas explorassem outros modos de interação, manipulação, expansão, troca e comunicação com o meio, entenda-se este meio como sendo o espaço físico, a música proposta, os objetos cênicos, os outros clowns e a plateia. De acordo com Kleber (2012), a improvisação é uma importante ferramenta na construção do clown. Improvisar implica o sujeito produzir um corpo exposto, disponível para o jogo, preparado para viver e atuar no momento presente. A técnica de improvisação integra o sujeito aos acontecimentos imediatos e às necessidades do momento, levando-o a experienciar um modo pessoal e específico de relação, de jogo, da produção de si, do [re] inventar-se, a partir do próprio corpo e das demais situações de interação, desenvolvendo nele a percepção, a prontidão e a comunicabilidade. Segundo Machado (2005, p. 13), o clown e o ambiente em que ele está inserido "dispõem-se mutuamente de um jogo de receber, trocar e devolver estímulos. Receber, trocar e devolver comicamente os estímulos do ambiente e do clown". Esta relação é que possibilita ao clown transformar o seu espaço de atuação e criar novos sentidos e significados, a partir das relações ali existentes. 


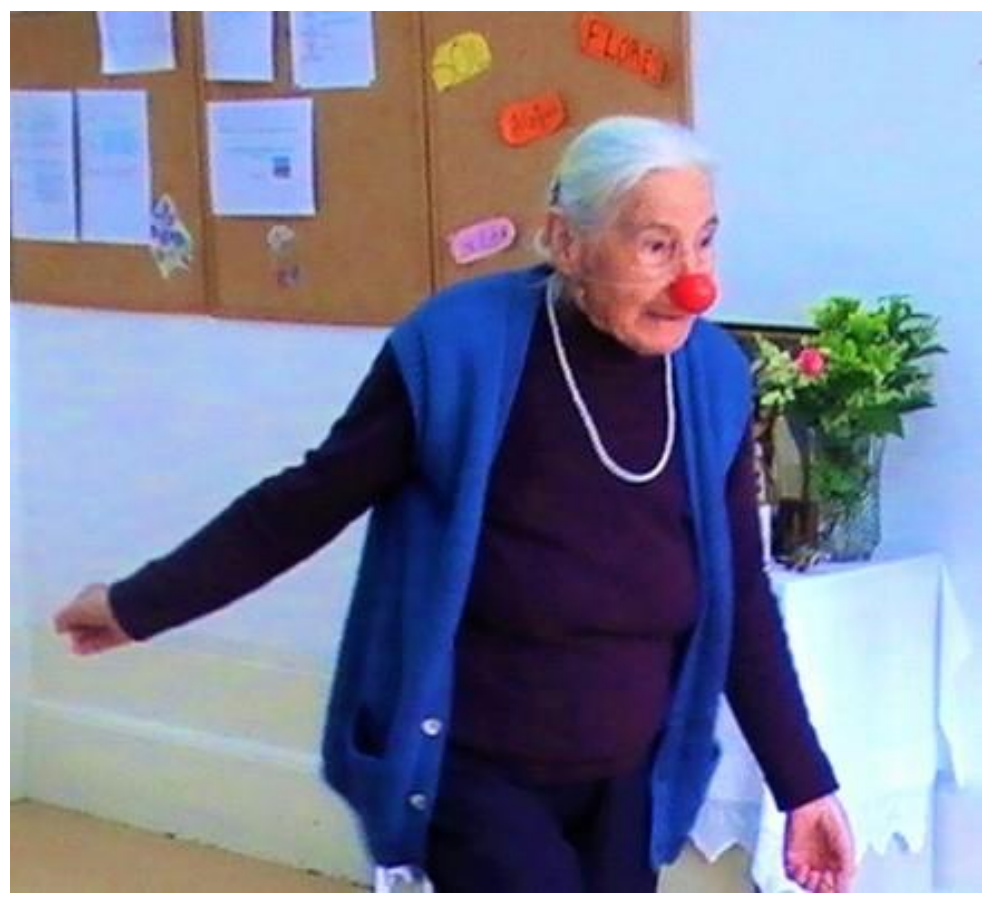

Imagem 22: Jogo teatral

Nos seus estudos, ao longo de assessorias sobre o trabalho do clown, Ferracini (2003) evidencia que as ações e reações do clown são todas corporificadas, isto é, o raciocínio do clown é inteiramente corpóreo, ele não só sente com o corpo, mas também pensa, dialoga e age através dele. Suas palavras estão em seu corpo, em seu dinamismo, em sua musculatura, bem estabelecidas, num estado particular de comunicação com o mundo à sua volta. Este modo de agir, emotivo e afetivo, conforme o autor supracitado, é que permite ao clown alterar a sua percepção sensitiva, como também expandir o seu estado de consciência, tornando-o apto a produzir imagens, relações, memórias, sensações e pensamentos que se organizam para ajustar uma resposta adequada às outras informações desencadeadas. Este estado de organicidade do clown é que vai determinar a forma como ele deve agir e reagir, segundo a sua própria lógica, por meio da sensibilidade, pelo campo do sentir.

Observamos que nos primeiros jogos teatrais aplicados a atuação das idosas era tímida e retraída, contudo, no decorrer da prática elas foram se mostrando mais desenvoltas, mais aptas para o jogo e para a improvisação. Pudemos constatar que o "sentir-se exposto", o "sentir-se observado" por uma plateia, contribuiu para que as idosas se livrassem da timidez e adquirissem uma maior liberdade, relaxamento e segurança no palco. O tipo de ambiente 
propiciado pelo programa (de interação, de descontração, de alegria e de criação), como também os vínculos relacionais ali já existentes, contribuíram para que a livre expressão fosse logo instituída. Segundo Kleber (2012), no trabalho de atuação do clown a livre expressão seria o substancial essencial para o sujeito atingir aquilo que muitos estudiosos denominam de estado de clown, percebido neste estudo como sendo um "estado de divertimento puro". Ferracini (2003) comenta que para atingir este estado é necessário o sujeito livrar-se das suas armaduras, despir-se dos seus estereótipos, desprender-se da sua própria imagem, sentir-se livre para brincar com a sua imperfeição, com os seus erros e aceitar o risível de si mesmo. Consoante o referido autor, os pilares que dão sustentação a este estado, e responsáveis também pelo preenchimento e veracidade da atuação do clown, são: o jogo, a brincadeira, a imaginação, a criação, a liberdade, a espontaneidade, o humor, o prazer, a alegria e acima de tudo a diversão. O que o sujeito experimenta ao atingir este estado é o emergir de outras possibilidades de ser, estar e fazer, além da sensação de que tudo é permitido ao seu clown. Seguem alguns comentários das idosas participantes do programa:

- É que nem sequer me passa pela cabeça o problema, porque estou tão embrenhada naquilo que se está a fazer, que pra mim é novo, que realmente pra mim diz muito. (ME, 77 anos)

- Tarde muito divertida, cheia de invenções e brincadeiras. Realmente, parece que voltamos a ser crianças. É bom brincar. (MJ, 70 anos)

- Pra mim é uma distração, é uma tarde diferente das que costumamos ter, e pronto, aprende-se certas coisas que é engraçado. (OS, 81 anos)

- É uma tarde muito divertida (...). Brincamos com o nariz de palhaço, cantamos, muito movimento de braço, é lindo. (MM, 88 anos)

- Foi lindo, uma tarde muito divertida, fartamos de rir, não esquecendo a parte palhaço. Gosto de tudo, agente ri-se um bocado, agente espairece, agente esquece a vida, esquece tudo. (FC, 80 anos)

- É uma alegria todos os trabalhos que temos ensaiado aqui, principalmente as atividades com as colegas. (...) São coisas novas que estamos a aprender e gosto muito do que estamos a fazer. (MC, 70 anos)

- Foi mais uma tarde de muito riso, alegria e convívio saudável, é uma terapia necessária para o corpo e principalmente para a mente, da qual eu gosto muito. (MJ, 70 anos) 
- Porque eu gosto de coisa alegre, gosto de distrair-me, e tudo que houver aqui eu tenho feito de tudo. (FO, 92 anos)

- Eu não sabia bem para o que vinha, seria a curiosidade, porque iria ocupar mais um espaço. A primeira vez que entrei eu vinha muito triste e saí alegre. (ME, 77 anos)

- Adorei a dinâmica do riso e dos reflexos de apontar umas para as outras. Mas o que deu mais interesse foi o mini teatro das freiras. (...) Deu para nos rir muito. (MC, 88 anos)

- Foi uma tarde engraçada em convívio, que dá a sensação de que somos mais amigas umas das outras. (RR, 75 anos)

- Eu acho que isto é muito importante pra nós, porque agente vai aprendendo. (EP, 82 anos)

Observamos que os jogos teatrais ajudaram a instaurar a alegria. Mesmo depois de concluídas as sessões as idosas continuavam a "clownear", isto é, a brincar, a caçoar, a se divertir, a rir de si próprias e das colegas. Depois de encerradas as atividades ainda se ouvia o ecoar das risadas e das palmas, que tomava conta dos corredores do CCIB.

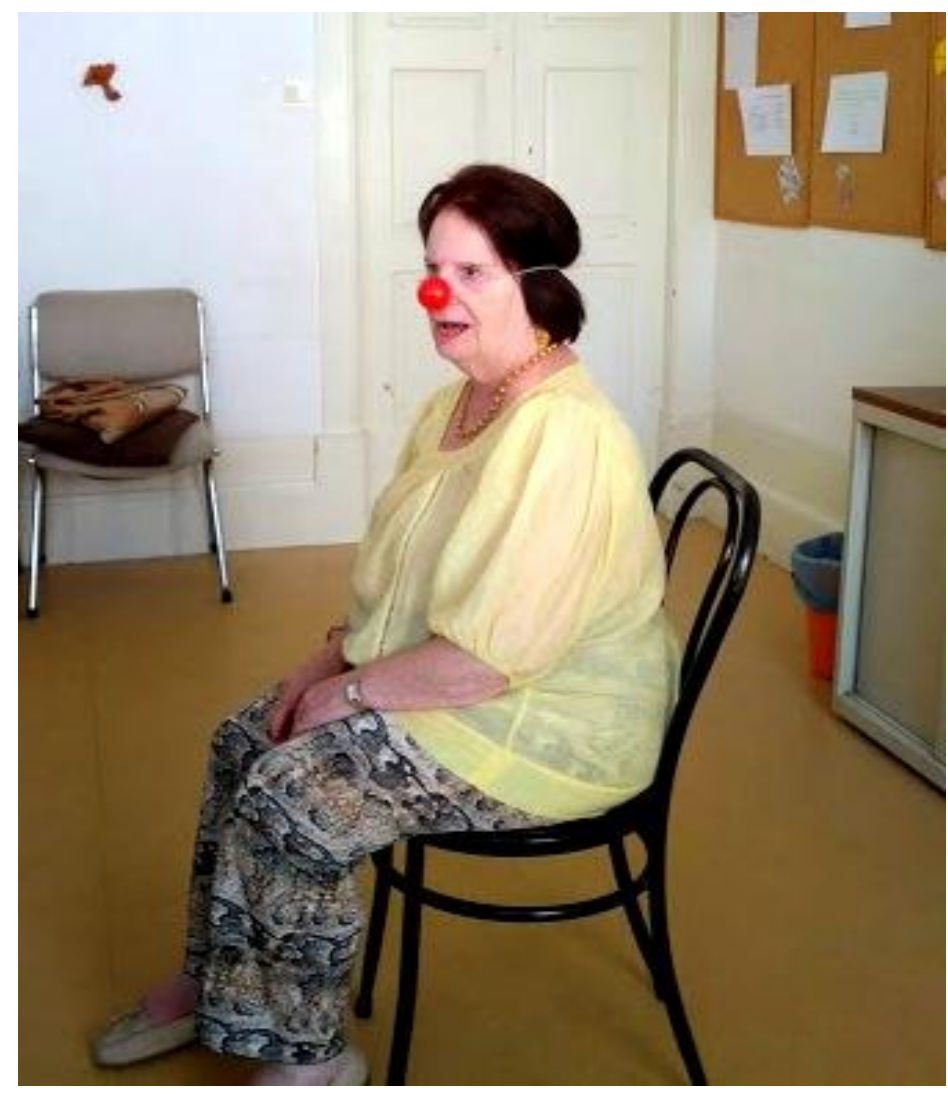

Imagem 23: Jogo teatral 


\section{CONSIDERAÇÕES FINAIS}

Aquilo que se procurou constituir como o cerne desta investigação verificar de que forma um Processo de Criação do Clown aplicado com idosos pode possibilitar bem-estar e vida com qualidade - fundamentou-se na implementação e efetivação do programa interventivo intitulado Humor e Bemestar na Velhice, onde pesquisa e ação foram reunidas a partir da integração de processos de Planejamento, Ação, Observação e Reflexão. O âmbito favorável do método da pesquisa-ação deu-se por duas razões: primeira, de o investigador ter podido realizar uma ação com princípios e práticas participativas, transformadoras e dialógicas; e segunda, de os agentes implicados na pesquisa terem podido desempenhar um papel ativo na realidade dos contextos observados e dizer algo acerca das suas experiências. Inferimos que esta metodologia, no âmbito dos Estudos Culturais, se encontrou particularmente apta para abordar questões relativas a estilos de vida e a práticas de atividades.

Neste estudo, como já foi referido na introdução, o nosso desafio consistiu em possibilitarmos aos idosos um espaço de inclusão, de motivação, de criação, de diversão, de conhecimento, de reflexão e de humanização, como também um espaço/tempo de retomada e recriação de valores considerados essenciais e preditivos para uma velhice bem-sucedida, como a liberdade, a autonomia, a autoaceitação, a autoestima, o autoconhecimento, a autoexpressão e a autorrealização, onde os componentes psicofísicos, sociais e culturais abrangem todos os domínios de satisfação e de realização pessoal. Valores estes considerados critérios inquestionáveis para se garantir um grau elevado de disposição emocional, uma individualidade saudável e uma vida social equilibrada, tanto no âmbito pessoal quanto no comunitário, e que apontam para uma forte relação com o ócio e com as reivindicações urgentes e próprias da velhice.

No que diz respeito ao programa Humor e Bem-estar na Velhice, desenvolvido com um grupo de frequentadores do Centro de Convívio para Idosos do Bonfim (CCIB), consideramos importante registrar que:

1. O acordo regulamentado com o CCIB constituiu um passo extremamente importante para a implementação do programa, como 
também para a definição do grupo e de toda a logística necessária para o cumprimento das atividades;

2. O programa foi muito bem acolhido pela direção do CCIB, que nos disponibilizou todo o apoio e toda a gestão necessária para a sua execução, como também foi muito bem aceito pelos frequentadores do Centro de Dia;

3. A entrevista realizada com as participantes do programa foi introduzida numa atmosfera de respeito e afeição, livre de intimidação e coibição. As idosas entrevistadas mostraram-se bastante motivadas, como também capazes, respondendo de forma adequada a todas as perguntas;

4. O programa propiciou às idosas um espaço adequado às suas capacidades físicas, características psíquicas e competências comportamentais, como também um espaço de confronto com as suas próprias limitações e dificuldades;

5. O programa facultou às idosas um ambiente de liberdade, de descontração, de relaxamento, de descanso e de diversão, como também de conscientização, de sensibilização, de aprendizagem, de criação, de sentir e de pensar pessoal, de amizade, de familiarização, de afetividade, de comunicação, de igualdade, de confiança, de cumplicidade e de troca;

6. A frequência regular das idosas, como também a motivação intrínseca, contribuiu de forma efetiva para o bom andamento dos trabalhos e para o cumprimento do calendário global do programa.

No que diz respeito ao processo de criação do clown, procedimento utilizado como estratégia operacional do programa Humor e Bem-estar na Velhice, consideramos importante registrar que:

1. O processo mostrou-se altamente válido, eficaz e precioso, além de nos ter favorecido um olhar multifacetado sobre a realidade vivida por cada participante nos contextos observados, dado a pluralidade de atividades que atravessaram este processo: corpo; expressão corporal; jogos tradicionais; jogos teatrais; clássicos de clown. 
Embasados no processo de observação e reflexão da ocorrência do percurso prático, apresentaremos, a seguir, uma síntese dos efeitos resultantes das atividades, a fim de identificarmos e obtermos provas que nos permitam responder as questões levantadas: A aplicação de um Processo de Criação do Clown num contexto social atribuído à velhice pode possibilitar bem-estar e potencializar a vida? As atividades que atravessam este processo podem ser percebidas como possibilidades de experiências de ócio?

As atividades de corpo:

Foi perceptível, no seguimento das atividades de corpo (ou preparação corporal), uma mudança progressiva no comportamento e nas atitudes corporais das idosas. Os procedimentos de alongamento corporal e de aquecimento muscular/articular propiciaram uma melhoria na capacidade de resistência para suportar o esforço físico e a fadiga durante o treinamento, como também uma melhoria na mobilização articular, na desenvoltura, na flexibilidade e na amplitude dos movimentos. As articulações, por exemplo, pareciam ter sido desprendidas dos "nós" que antes as retinham. Foi notório o aumento da ação e dos reflexos corporais, como também da consciência da atitude vertical e dos movimentos, que se tornaram quase automáticos. Já os procedimentos de massagem e relaxamento corporal, ajudaram a reduzir as tensões, a provocar o descanso, o apaziguamento e o alívio muscular, estimulando a sensação de revigoramento e o sentimento de bem-estar psicofísico.

As técnicas de integração postural (base de apoio, eixo corporal e encaixe do quadril) facultaram às idosas uma base mais segura, um eixo correto e um melhor equilíbrio em postura vertical, o que muito contribuiu para que elas, no decorrer do percurso prático, se mantivessem de pé por um tempo bem mais prolongado do que o habitual, sem pedirem para sentar. Já os exercícios de deslocamento (transferência de peso, forma de pisar, caminhar em linha reta, modo de abaixar), ritmo e percepção espacial, levaram as idosas a desenvolver uma melhor precisão e dinamicidade no caminhar, agora mais correto, mais seguro, com menos esforço e sem a necessidade de apoios.

Inferimos que o contentamento com o próprio desempenho e com os resultados obtidos serviu de motivação para que as idosas participassem, se 
envolvessem e se esforçassem a cada exercício. Foi notório o desejo das idosas de superar as limitações e dificuldades impostas pelo próprio corpo, como também os desafios colocados pelos exercícios. Se no princípio elas duvidaram que fossem capazes de cumprir com as atividades corporais porque, segundo elas, se sentiam velhas, doente, enferrujadas, pesadas, cansadas e preguiçosas, a prática mostrou o contrário. No decorrer do processo as idosas, no seu limite, a seu modo e no seu devido tempo, conseguiram realizar, habilmente, todos os exercícios propostos. Todas elas mantiveram-se potencialmente ativas e participativas nas atividades de corpo, ainda que um e outro exercício demandasse comprometimento, tempo e esforço físico. Mais a mais, o respeito e o cuidado com o próprio corpo foram se tornando uma preocupação cada vez mais constante, e a autonomia motora um ponto de referência cada vez mais seguro.

As atividades de expressão corporal:

Inferimos que a apreensão de uma base de apoio mais segura, de um eixo corporal mais correto, de um melhor equilíbrio em postura vertical, de uma melhor precisão e segurança no caminhar e de uma melhor desenvoltura, flexibilidade e amplitude nos movimentos foi crucial para o bom andamento das atividades de expressão corporal. Todas estas conquistas permitiram que as idosas adquirissem uma maior confiança no próprio corpo, como também uma maior desinibição, liberdade e concentração para a criação. Os trabalhos de expressão corporal levaram as idosas a aprimorar ainda mais a precisão e a fluidez dos movimentos, principalmente dos braços e da coluna vertebral. Os exercícios de expressão corporal também possibilitaram que as idosas desenvolvessem pequenas percepções, tais como: ritmo, tempo, espaço, planos, sensações e estados corporais.

Inferimos que a liberdade pessoal foi o substrato essencial que permitiu a criação e a presença expressiva no seu estado mais puro. Os vínculos relacionais ali já existentes, como também a coesão de grupo, contribuíram, de forma efetiva, para que a liberdade fosse logo instituída. Essa experiencia real de liberdade (sem exigências, sem responsabilidades e sem opressão) foi que possibilitou a espontaneidade e a livre expressão. Esta verificação se deu, sobretudo, naqueles 
exercícios em que as idosas foram orientadas a fisicalizar sentimentos e emoções. Nestes exercícios os movimentos eram justificados pela veracidade das ações, carregadas de intenção, de veracidade, de sentimento e emoção, dando espaço ao envolvimento, à expressão e à criação. Além disto, as atividades de expressão corporal facultaram às idosas o desenvolvimento da atenção e da concentração, o que contribuiu para que elas se mantivessem inteiramente voltadas para o seu trabalho pessoal, sem distrações e sem medo.

As intervenções corporais (corpo e expressão corporal) constituíram um excelente meio de prover a independência e a autonomia motora. Além da dimensão motora, estas atividades possibilitaram o desenvolvimento da dimensão cognitiva, afetiva e social das idosas, e que estão intimamente inter-relacionadas com o sentimento de satisfação e de realização pessoal.

É importante registramos que nestes contextos experienciais a música foi um elemento de suma importância. Enquanto estímulo sonoro integrado ao movimento, a música impulsionou os exercícios de corpo e de expressão corporal, de modo a incitar e conduzir os movimentos, evocar e libertar sentimentos e emoções, estimular a ação, a imaginação e a criação.

Os jogos tradicionais:

Inferimos que a prescrição e a dinamicidade dos jogos tradicionais incitaram a mente e o corpo das idosas, contribuindo para o desenvolvimento de faculdades cognitivas (a percepção, a atenção, a concentração, a linguagem, o raciocínio, a imaginação e a memória), de habilidades manipulativas (lançar, receber, rebater e agarrar objetos) e de habilidades rítmicas (a coordenação, a sincronia, a memorização e a repetição de movimentos).

A competição e os obstáculos impostos nos jogos tradicionais serviram de motivação para o jogo. Determinadas em vencer os desafios e o próprio jogo, as idosas buscaram valer-se da sua própria experiência, competência, eficácia, conhecimento e da sua vivência pessoal para responder aos imprevistos. Por outro lado, o sentido de cooperação entre as idosas ajudou a estabelecer o equilíbrio e o senso de democratização nos jogos, ou seja, ao mesmo tempo em que as idosas desejavam "vencer" o jogo, buscavam também facilitar a ação das colegas, para que elas continuassem a jogar e a se divertir. O senso de 
cooperação possibilitou a participação contínua, levando as idosas a experimentar a satisfação de jogar e se divertirem juntas.

Os jogos tradicionais facultaram a brincadeira, a diversão e a vivência da alegria, que consistiram na realização e no prazer do próprio ato de jogar. Foi na intensidade dos jogos, no seu poder de fascinação, excitação e exaltação que a brincadeira, o divertimento e a alegria emergiram. Mais a mais, a cada jogo proposto as idosas foram se mostrando cada vez mais livres, mais imaginativas, mais atentas, mais concentradas, mais seguras, mais capazes e mais confiantes em si próprias e nas colegas.

Os jogos teatrais:

Das atividades e técnicas que atravessaram o processo de criação do clown, o jogo teatral foi o "trampolim" que possibilitou às idosas mergulhar no universo mágico, fantasioso, imaginativo, lúdico e quimérico do clown, abrindo as portas da sensibilidade, da criação, do devaneio, da capacidade de sentir, de se emocionar, de se divertir, de rir, de refletir sobre si, de experienciar distintas realidades e de compreender diferentes visões da vida e do mundo.

Se nas primeiras sessões as idosas revelaram-se tímidas para "clownear", no decorrer do processo elas foram se mostrando cada vez mais desenvoltas, aptas e criativas. O "sentir-se exposto", o "sentir-se observado" por uma plateia, contribuiu, de forma efetiva, para que as idosas se livrassem da timidez e adquirissem uma maior liberdade, relaxamento e segurança no palco.

No jogo teatral a técnica de improvisação, enquanto modo de ação e forma de expressão momentânea, qualificou as idosas no que diz respeito à percepção, à ação, à espontaneidade e à habilidade de jogo, além de levá-las a explorar outros modos de interação, manipulação, expansão, troca e comunicação com o meio, desenvolvendo nelas o sentido de atenção, de presença e de cumplicidade.

A situação do palco permitiu que as idosas assumissem "outros papéis". Deste modo, munidas da máscara do clown, as idosas trouxeram para a cena múltiplos personagens (mãe, vendedora, alcoviteira, atleta, cozinheira, feiticeira, professora, freira, rendeira, dançarina, agricultora, cantora, costureira, médica, rezadeira, cabeleireira, etc.), como também situações corriqueiras da vida (fazer faxina, fazer compras no supermercado, cozinhar, passear com o cão, dialogar 
com a vizinha, ir ao salão de beleza, cuidar de crianças, jardinar, etc.) e desejos (voltar para a aldeia, passear em Paris, dançar para muita gente, ficar rica, ir ao Brasil, conhecer o fadista Camané, etc.).

No jogo teatral alguns clowns eram patéticos, enquanto outros se revelavam sérios, alegres, chorões, irados, tristes, medrosos, tímidos ou desconfiados. Alguns clowns eram pachorrentos, ao ponto que outros eram ligeiros e desembaraçados. Existiram aqueles clowns que sentiam dor de barriga, peidavam e arrotavam em cena, como também aqueles que dançavam e cantavam para a plateia.

Inferimos que o nariz vermelho do clown foi o dispositivo que estimulou a brincadeira e a diversão, concedendo às idosas uma atitude de liberdade, naturalidade e espontaneidade no seu estado mais puro. Foi notória a mudança no comportamento e nas atitudes das idosas ao colocarem o nariz, foi como se um mecanismo interno tivesse sido acionado, como se a criança interior tivesse despertada. Bastava que uma delas entrasse em cena com um andar meio desajeitado e uma expressão um pouco mais exagerada e, pronto, já se ouvia sonoras gargalhadas da plateia.

O nariz vermelho também possibilitou às idosas uma primeira vivência da utilização cômica do corpo, que foi particular para cada uma delas. De forma livre, natural e espontânea, as idosas produziram movimentos exagerados, caricaturescos e carregados de comicidade. Esta experiência real de liberdade levou as idosas a experimentar o emergir de outras formas de ser, estar e fazer até antes não acessadas, como também a sensação de que é permitido.

O "clownear" instaurou a alegria nas tardes do Centro de Convívio para Idosos do Bonfim. As idosas riam da ousadia ou da timidez como um e outro clown se apresentava em cena, da idiotice ou do modo ridículo como um e outro clown se portava em cena, como também das palhaçadas, das zombarias, das chacotas, dos erros, dos incidentes e das situações fortuitas e inusitadas surgidas no ato da cena. E mesmo depois de encerradas as sessões, ainda se ouvia o ecoar das risadas e das palmas pelos corredores do CCIB.

Inferimos que no decorrer do processo de criação do clown as idosas - no seu limite, a seu modo e no seu devido tempo - conseguiram produzir e funcionar muito bem com as capacidades físicas, psicológicas, cognitivas e sociais que dispunham, mostrando-se potencialmente ativas, participativas, envolvidas, 
imaginativas e criativas, ainda que uma e outra atividade demandasse comprometimento, tempo e esforço físico.

Inferimos também que as atividades e técnicas que atravessaram este processo contribuíram, de forma efetiva, para a reabilitação física, cognitivocomportamental e social das idosas, além de terem possibilitado momentos de liberdade, de criação, de satisfação, de prazer, de descanso, de relaxamento, de descontração, de diversão, de alegria, de felicidade e de evasão.

No transcurso do processo a transformação mais marcante foi a interação social. Todas as atividades propiciaram às idosas experiências grupais e compartilhadas, concedendo-Ihes uma proximidade entre si e um contato bem mais direto e mais íntimo do que o fazem normalmente no cotidiano, consolidando ainda mais as amizades. Foi notório o convívio harmonioso e saudável entre as idosas, pautado no sentimento de respeito e de consideração, como também na união, na partilha e no apoio mútuo, o que favoreceu o desenvolvimento de laços fortemente afetuosos. O convívio positivo entre as idosas serviu também como auxílio para que elas encontrassem sentido nas suas experiências pessoais, com uma incidência benéfica para todo o grupo.

$\mathrm{Na}$ velhice, de acordo com Neri (2009), cultivar as velhas amizades e estabelecer novas relações, mais ainda da mesma geração, oferece garantias de pertencimento a uma rede de relações. Como em qualquer idade a pessoa idosa também necessita de amigos e de companheirismo, necessita saber que é amada, cuidada e valorizada. Construir relações, principalmente de qualidade, ajuda o idoso a conservar emoções positivas em circunstâncias de sofrimento, ansiedade e estresse, ou seja, quanto maior os afetos positivos que resultam dessas relações, mais fortalecido ele se torna, aumentando a sua capacidade de processar recursos psicológicos para enfrentar as emoções negativas.

Outro elemento também importante, e que deve ser levado em consideração, foi a aprendizagem. O processo de criação do clown, dado ao seu caráter didático e formativo, facultou às idosas a apreensão de conhecimentos diversos, ainda que basilares, acerca do corpo, da expressão corporal, da elaboração da cena e da performance do clown. Os fatores que propiciaram a aprendizagem foram: a abertura para o novo; o desejo de aprender; a vontade de fazer; a participação ativa; a entrega pessoal e total; o envolvimento com o processo e com o grupo; e a intervenção precisa do investigador. Mais a mais, o 
programa também possibilitou às idosas espaços de abertura para perguntas e discussões: sobre o que estava sendo realizado; sobre o trabalho do ator; sobre a construção da cena; sobre o trabalho do clown; e sobre os resultados alcançados.

Toda esta comprovação vem contestar a ideia de que ser idoso é ser ranzinza, antiquado, conservador, inadequado, portador de dificuldades, inválido, menos interessado, menos capaz, menos criativo, menos seguro e menos produtivo. Ou de que ser idoso é parar de ousar, se prender no passado, contar histórias, rezar e se preparar para a morte.

Contrariando todas estas imagens negativas, discriminatórias e preconceituosas, construídas socialmente acerca da pessoa idosa, as participantes do programa, no seu conjunto, mostraram-se fisicamente, emocionalmente e intelectualmente aptas, tanto para as atividades corporais, como também para os jogos e para o fazer teatral, reconhecendo o seu potencial, se colocando abertas para a experienciação, enfrentando as suas limitações e os desafios e exigências que se apresentaram em diferentes momentos no processo.

Como as participantes proferiram na entrevista, o envolvimento ativo com a vida pessoal e social, a saúde e o convívio são condições essenciais para se levar uma vida satisfatória e feliz. O mais importante nessa altura da vida, segundo elas, é a pessoa manter um comportamento pró-ativo, é a pessoa "não ficar parada", "não ficar quieta" e "sentir que ainda sabe fazer as coisas", de forma a ultrapassar a letargia e a conduta estática de quem se esqueceu como protagonizar os próprios dias. Ou seja, estar ativo, ter saúde e amigos dá sentido à vida e conduz a pessoa para uma valoração da própria existência.

De acordo com os referenciais teóricos apreendidos, embora os estudos apontem uma visão mais otimista em relação à velhice, no contexto atual a sociedade ainda tem demonstrado dificuldades em lidar com o envelhecimento dos seus cidadãos. Estamos inseridos numa sociedade onde envelhecer significa perder as qualidades associadas à juventude, tais como a beleza, a saúde, a força, a agilidade, a habilidade, os papéis desempenhados, o poder econômico, o status, o respeito, os direitos e responsabilidades; onde o idoso tem a sua autoimagem depreciada e associada a aspectos negativos como a debilidade física, a demência, a decrepitude, as perdas funcionais, a doença, a dependência e a perda da dignidade; onde o idoso é tolhido de viver a sua liberdade e de gerir a sua própria vida; onde $o$ idoso tem a sua experiência de vida desqualificada e 
suas necessidades afetivas e questões sexuais ignoradas. Segundo Fonseca (2004, p. 106), outra ideia ainda bastante generalizada é a de que a velhice "corresponderia a uma espécie de 'segunda infância', com tudo o que isso traduz em termos de infantilização, dependência e diminuição da responsabilidade individual dos idosos, conduzindo a uma inevitável redução do seu estatuto social".

Todos estes estigmas negativos, conforme a Organização Mundial da Saúde (CFP, 2009), terminam por reforçar sentimentos de inadequação e baixaestima no indivíduo idoso, levando-o a perder o entusiamo para seguir com a vida, a desistir dos seus objetivos, a se recolher no passado, a se isolar, a se excluir e a não encontrar sentido para a sua existência. Segundo Paz (2011), quando o idoso se sente dominado por conceitos negativos e rodeado por um ambiente hostil, ele próprio se vê como uma pessoa inútil, inválida, incapaz, incompetente, indesejada, como um estorvo para a família e para a sociedade, como um escravo da vontade dos outros e inadequado no contexto social e cultural no qual está inserido, demonstrando, com tudo isso, comportamentos de frustração, ressentimento e desamparo. Estas são as razões pelas quais muitos idosos são levados a levar uma vida anti-social, a se afastar das pessoas e a elaborar uma personalidade solitária. Não obstante, independente dos sentimentos relacionados à velhice, se positivos ou negativos, o que se verifica é que para a maioria dos indivíduos essa etapa da vida vem acompanhada de temores sobre o que se passará nos anos seguintes, de receios ligados ao pressentimento de inutilidade, de sentir-se deslocado e isolado, contribuindo para que a ansiedade e a angústia se instalem.

De acordo com a OMS, é de responsabilidade nossa, dos governos, das organizações não-governamentais e da família - por intermédio de estudos, opniões e reflexões - construirmos uma nova consciência que busque quebrar com os mitos, tabus e preconceitos erigidos acerca da pessoa idosa, permitindo que ela exerça o seu direito de participação plena numa vida social, cultural, política e econômica. Segundo Fonseca (2004, p. 109), cabe a nós olharmos para a pessoa idosa exatamente como pessoa, "com direitos e obrigações, com alegrias e angústias, com desejos e frustrações, enfim, exatamente como uma criança, um jovem ou um adulto, ou seja, como uma pessoa que vive a sua condição de vida à semelhança de qualquer outra". 
Em resposta à primeira questão de investigação - A aplicação de um Processo de Criação do Clown num contexto social atribuído à velhice pode possibilitar bem-estar e potencializar a vida? - coube-nos reconhecer que o Processo de Criação do Clown, implementado e efetivado no Centro de Convívio para Idosos do Bonfim (CCIB), mostrou-se altamente eficaz, válido e precioso, enquanto via de inclusão, de interação, de motivação, de criação, de entretenimento, de aprendizagem e de humanização. O processo ajudou a romper com a falta de motivação das idosas, como também com o tédio da rotina, com o cansaço físico/mental, com o sentimento de inutilidade e com a sensação de vazio, além de ter ajudado a amenizar a angústia decorrente da inatividade, da viuvez e da solidão, cumprindo a função de "desvio de atenção" de um cotidiano costumeiro, quase insuportável, para uma dimensão oposta da vida comum.

Mais do que uma estratégia operacional orientada para a diversão nobre e a vivência da alegria, o processo introduziu as idosas em ações de melhoria, de transformação e de crescimento pessoal, facultando a harmonização entre os seus componentes físico, psíquico, intelectual e social, promovendo o bem-estar. Mais a mais, o processo, que abarcou atividades amplas (de natureza física, artística, intelectual e social), possibilitou às idosas uma pluralidade de experiências positivas, que poderão ser lembradas e contadas com alegria e bemquerer. Estas experiências vieram "transformar o hoje", suprir a carência de bons momentos atuais e potencializar a vida.

Em resposta à segunda questão de investigação - As atividades que atravessam este processo podem ser percebidas como possibilidades de experiências de ócio? - coube-nos reconhecer que as atividades desenvolvidas no decorrer do Processo de Criação do Clown foram apreciadas pelas idosas. Os contextos experienciais foram entremeados mais por experiências beneficiosas, satisfatórias, realizadoras e felizes do que o contrário, graças ao tipo de ambiente favorecido, ao desfrute das relações e à qualidade da aprendizagem. Tais contextos facultaram a liberdade, a criação, o conhecimento, a reflexão, a diversão, a vivência da alegria, a sensação gratificante, o descanso e a evasão. Todos estes valores, de caráter e orientação positivos, são os mesmos reivindicados pelo ócio humanista, e apontam para a vivência lúdica, criativa e autotélica do ócio. 
De acordo com Manuel Cuenca (2009), o ócio, enquanto fruto das horas livres, do descanso e da tranquilidade, representa uma condição da existência humana, e diz respeito às atividades e às ações não utilitaristas. Como já foi mencionado na introdução desta tese, ócio é toda e qualquer ocupação relacionada com o mundo da subjetividade, da criatividade, da emotividade, da contemplação, do conhecimento e da reflexão. Segundo o autor, falar de ócio é falar de sentido de vida, de valores essenciais, de uma experiência integral, necessária e enriquecedora da natureza humana, pautada no sentimento de liberdade, de satisfação e de felicidade. Falar de ócio é falar de desenvolvimento psicofísico e enriquecimento intelectual, cultural e espiritual. Falar de ócio é falar também de autoexpressão, de autoconhecimento, de autorrealização, de autoestima, de saúde, bem-estar e qualidade de vida.

Segundo o autor supracitado, a vivência lúdica do ócio é algo que nos devolve a natureza humana e que nos distancia da crua realidade cotidiana. $\mathrm{O}$ lúdico nos reporta para o mundo da fantasia, nos devolve a liberdade, a alegria de espírito e introduz a felicidade no nosso cotidiano. A vivência criativa do ócio está ligada a processos de criação, formação, reflexão e às possibilidades de abertura e de comunicação. O ócio criativo nos possibilita expressar sentimentos, emoções, estados de espírito, ideias, pensamentos, impressões, modos de vida e de pontos de vista. Quanto à vivência autotélica, isto é, à experiência de ócio em si mesmo, esta tem uma direcionalidade positiva e beneficiosa para o nosso desenvolvimento pessoal e social, por se tratar de uma vivência de caráter desinteressado, que presume o desprendimento e a independência no que diz respeito aos interesses e valores da vida cotidiana. O ócio autotélico nos propicia momentos de liberdade, de reflexão e de contemplação, de forma satisfatória e realizadora.

$\mathrm{Na}$ atualidade distintos autores vêm apontando a experiência de ócio como uma das mais importantes formas de expressão de liberdade, como uma experiência irrenunciável e como um "direito humano fundamental", que independe da idade, do gênero, da formação, da etnia, da cultura, do status social, da religião e das habilidades. $O$ ócio, nas suas mais variantes possibilidades, é percebido hoje como um dos principais contributos para o desenvolvimento humano; como um espaço para se cultivar o corpo, a mente e o espírito; como fonte de saúde e prevenção de enfermidades físicas e psíquicas; 
como um "corretivo" equilibrador de desajustes e carências do tipo pessoal e social; como um recurso eficaz para se atingir ânimos positivos, capaz de possibilitar o bem-estar e potencializar a vida. Nesta perspectiva, valorizar o ócio no contexto social atribuído à velhice torna-se um aspecto primordial e extremamente importante.

Acreditamos que a presente tese, situada no âmbito dos Estudos Culturais, vem dar um contributo para a construção de uma nova consciência que busque quebrar com os tabus e mitos erigidos acerca da velhice, a fim de superarmos as imagens negativas, discriminatórias e preconceituosas construídas socialmente acerca da pessoa idosa. Acreditamos, também, que este estudo é de fundamental relevância para as instâncias produtoras de políticas de envelhecimento, que precisam se preparar para as transformações que começam a ter lugar num cenário de envelhecimento presente e futuro, e que deverão se adequar à essa nova realidade. De acordo com o Conselho Federal de Psicologia do Brasil (2009, p.10), face ao fenômeno do envelhecimento demográfico global, "interagir saberes e desenvolver competências para trabalhar de modo interdisciplinar são requisitos mínimos para que os trabalhos produzidos pelas diversas profissões ofereçam respostas eficazes para uma vida digna para os idosos neste futuro próximo".

Se me perguntarem o que é ser velho Eu direi, não sei. E de fato não sei Mas sei que na velhice O homem se torna aquilo que é Um esboço inacabado De uma obra dele todo

Kleber J. Santos 


\section{REFERÊNCIAS BIBLIOGRÁFICAS:}

Baptista, M. M. (2009). Cultura: Metodologias e investigação. Col. Cultura Portuguesa - Declinações Latino-Americanas, no 3. Ed. Maria Manuel Baptista. Lisboa: Ver o Verso Edições;

Baudelaire, C. (1998). Escritos sobre arte. Organização e tradução Plínio Augusto Coelho. São Paulo: Imaginário;

Berge, Y. (1975). Viver o seu corpo. Tradução Rui Alecrim. Lisboa: Compedium;

Bergson, H. (1983). O riso: ensaio sobre a significação do cômico. Rio de Janeiro: Zahar Editores;

Bize, P. R. \& Vallier, C. (1985). Uma vida nova: a terceira idade. Lisboa: Ed. Verbo;

Boal, A. (1978). Duzentos exercícios e jogos para o actor e o não actor, com ganas de dizer algo através do teatro. Lisboa: Cooperativa de Acção Cultural SCARL;

Burgess, R. G. (1997). A pesquisa de terreno: uma introdução. Tradução: Eduardo de Freitas e Maria Inês Mansinho. Oeiras: Celta Editora Lda;

Burnier, L. O. (2001). A arte de ator - Da técnica à representação. Campinas: Editora da Unicamp;

Conselho Federal de Psicologia (2009). Envelhecimento e subjetividade: desafios para uma cultura de compromisso social. Brasília: Liberdade de Expressão;

Coutinho, C. P. Metodologia de Investigação em Ciências Sociais e Humanas: Teoria e Prática. Coimbra: Edições Almedina;

Cuenca, M. C. (2009). Ócio Humanista. Dimensiones y manifestaciones actuales del ocio. Documentos de Estudios de Ocio, ㄲo 16. Instituto de Estudios de Ocio. Bilbao: Universidad de Deusto;

Cuenca, M. C. (2014). Ócio valioso. Bilbao: Universidad de Deusto;

Cunha, C.S.R. (2012). Animação teatral e terceira idade: contributos para um envelhecimento ativo. Dissertação de Mestrado, UMinho, Braga, Portugal;

Damásio, A. (2000). O mistério da consciência: do corpo e das emoções ao conhecimento de si. Tradução Laura Teixeira Motta. São Paulo: Companhia das Letras;

Dias, I. M. G. P. (2011). Dor no idoso: satisfação com o tratamento. Dissertação de Mestrado, Instituto Superior Politécnico de Viseu, Viseu, Portugal;

Dorneles, J. L. (2003). Clown, o avesso de si: Uma análise do clownesco na pósmodernidade. Dissertação de Mestrado, UFRGS, Porto Alegre, RS, Brasil;

Escosteguy, A. C. D. (2010). Cartografia dos Estudos Culturais: Uma versão latino/americana. Ed. on-line. Belo Horizonte: Autêntica;

Federici, C. A. G. (2004). De Palhaço e Clown: que trata de algumas das origens e permanências do oficio cômico e mais outras coisas de muito bom gosto e passatempo. Dissertação de Mestrado, UNICAMP, Campinas, SP, Brasil;

Ferracini, R. (2003). A arte de não interpretar como poesia corpórea do ator. Campinas: Ed. da Unicamp;

Fonseca, A. M. G (2004). Uma abordagem psicológica da "passagem à reforma"desenvolvimento, envelhecimento, transição e adaptação. Tese de Doutorado. Instituto de Ciências Biomédicas de Abel Salazar, Universidade do Porto, Porto, Portugal; 
Francileudo, F. A. (2009). Desvelando o valor do tempo para si: um estudo hermenêutico sobre o sentido ontológico do ócio. Dissertação de Mestrado, UNIFOR, Fortaleza, CE, Brasil;

Gil, J. (2001). Movimento total: o corpo e a dança. Trad. Miguel Serras Pereira. Sta. Maria da Feira: Relógio D’Água Editores;

Guerra, I. C. (2006). Pesquisa Qualitativa e Análise de Conteúdo. Cascais: Princípia Editora;

Huizinga, J. (2000). Homo Ludens. Tradução: João Paulo Monteiro. São Paulo: Editora Perspectiva;

INE, IP (2013). Anuário Estatístico de Portugal 2012. Instituto Nacional de Estatística, IP. Lisboa: Portugal;

Johnson, R., Escotesguy, A. C., \& Schulman, N. (1999). O que é, afinal, Estudos Culturais? Belo Horizonte: Editora Autêntica;

Kleber, K. (2012). Corporeidade e Fisicidade: O treinamento do clown enquanto instrumental técnico e artístico na formação do ator. Lisboa: Chiado Editora;

Koudela, I. D. (1990). Jogos Teatrais. 2ª edição. São Paulo: Editora Perspectiva S.A.;

Lakatos, E. M. \& Marconi, M. A. (1991). Fundamentos de Metodologia Científica. 3a edição. São Paulo: Editora Atlas;

Machado, M. A. A. P. (2005). Uma nova mídia em cena: corpo, comunicação e clown. Tese de Doutorado, PUC, São Paulo, SP, Brasil;

Matos, D. (2009). A formação do palhaço: técnica e pedagogia no trabalho de Angela de Castro, Esio Magalhães e Fernando Cavarozzi. Dissertação de Mestrado, UDESC, Florianópolis, SC, Brasil;

Mello, M. T. S. S. (2009). A pesquisa-ação no cotidiano de práticas pedagógicas: experiências multiculturais e possibilidades institucionais. Dissertação de Mestrado, UFRJ, Rio de Janeiro, RJ, Brasil;

Minayo, M. C. S. \& Coimbra Jr., C. E. A. (org.) (2002). Antropologia, saúde e envelhecimento. Organizado por Maria Cecília de Souza Minayo e Carlos E. A. Coimbra Jr. Rio de Janeiro: Editora FIOCRUZ;

Mota, J. (1997). A atividade física no lazer: reflexões sobre a sua prática. Lisboa: Livros Horizonte;

Neri, A. L. (1995). Psicologia do Envelhecimento: Temas selecionados na perspectiva de curso de vida. Anita Liberalesso Neri (org.). Campinas: Papirus Editora;

Neves, L. R. (2006). O uso dos jogos teatrais na educação: uma prática pedagógica e uma prática subjetiva. Dissertação de Mestrado, UFMG, Belo Horizonte, MG, Brasil;

Nogueira, F. N. N. (2005). A vivência estigmatizada do envelhecimento na contemporaneidade: do indesejável ao inevitável. Dissertação de Mestrado, UNIFOR, Fortaleza, CE, Brasil;

Nunes, M. T. A. (2007). Gênero e Cidadania nas Imagens da História. Comissão para a cidadania e igualdade de gênero. Lisboa: SerSilito;

Organização das Nações Unidas (2003). Plano de ação internacional contra o envelhecimento, 2002/Organização das Nações Unidas. Tradução de Arlene Santos. Brasília: Secretaria Especial dos Direitos Humanos;

Organização Pan-Americana da Saúde (2005). Envelhecimento ativo: uma política de saúde. World Health Organization. Trad. Suzana Gontijo. Brasília;

Organização Pan-Americana da Saúde (2012). Atenção à saúde do idoso: Aspectos conceituais. Organização: Edgar Nunes de Moraes. Brasília; 
Pantano, A. A. (2007). A personagem palhaço. São Paulo: Editora UNESP;

Pavis, P. (1999). Dicionário de Teatro. São Paulo: Ed. Perspectiva;

Rooyackers, P. (2003). 101 Jogos dramáticos: aprendizagem e diversão com jogos de teatro e faz-de-conta. Porto: ASA Editores S.A.;

Sacchet, P. O. F. (2009). Da discussão "Clown ou palhaço" às permeabilidades de clownear-palhaçar. Dissertação de Mestrado, UFRS, Porto Alegre, RS, Brasil;

Silva, J. S. V. (2010). Funcionalidade e bem-estar psicológico em idosos residentes na comunidade: um estudo exploratório. Dissertação de Mestrado, Universidade de Lisboa, Lisboa, Portugal;

Silva, S. M. (2009). Envelhecimento ativo: trajetórias de vida e ocupações na reforma. Dissertação de Mestrado. Faculdade de Economia da Universidade de Coimbra, Coimbra, Portugal;

Spolin, V. (2005). Improvisação para o teatro. Trad. De Ingrid Dormien Koudela e Eduardo José de Almeida Amos. São Paulo: Ed. Perspectiva;

Squire, A. (2005). Saúde e bem-estar para pessoas idosas. Trad. Hugo P. Godinho e Joana P. Barros. Lures: Lusociência - Edições técnicas e científicas;

Thiollent, M. (1992). Metodologia da pesquisa-ação. São Paulo: Cortez;

Viveiros de Castro, A. (2005). O elogio da bobagem - palhaços no Brasil e no mundo. Rio de Janeiro: Ed. Família Bastos.

\section{ARTIGOS E REVISTAS}

Aquino, C. A. B. \& Martins, J. C. O. (2007). Ócio, lazer e tempo livre na sociedade do consumo e do trabalho. Fortaleza: Revista mal-estar e subjetividade, v. VII, n 2, pp. 479-500;

Baldin, C. B. \& Fortes, V. L. F. (2008). Viuvez feminina, a fala de um grupo de idosas. Passo Fundo: RBCEH, v. 5, n 1, pp. 43-54;

Baptista, M. M. (2009). Estudos Culturais: o que e como da investigação. Carnets, Cultures littéraires: nouvelles performances et développement, ํo spécial, automne/hiver, pp. 451-461;

Both, T. L., Alves, A. R., Pereira, C. \& Teixeira, T. P. (2012). Revista Brasileira de Ciência do Envelhecimento Humano. V. 9, pp. 67-78;

Câmara, H. C. (2013). Análise de conteúdo: da teoria à prática em pesquisas sociais aplicadas às organizações. Gerais: Revista Interinstitucional de Psicologia. 6 (2), pp. 179-191;

Cardoso, M. A. (2007). Jogos teatrais na sala de aula: um manual para o professor. Fênix: Revista de História e Estudos Culturais. V. 4, ano IV, № 2;

Conferência Internacional sobre Envelhecimento (2012). Livro de Atas. CISE Faculdade de Ciências Médicas, Universidade Nova de Lisboa. Lisboa: Edições Fundação D. Pedro IV;

Côrte, B. (2009). Comunicação: instrumento de formação para a longevidade. Envelhecimento e subjetividade: desafios para uma cultura de compromisso social. 1를 edição, pp. 51-62; 
Costa, M. V., Silveira, R. H. \& Sommer, L. H. (2003). Estudos Culturais, Educação e Pedagogia. Revista Brasileira de Educação. № 23, pp. 36-61;

Costa, F. S. (2005). A máscara e a formação do ator. Florianópolis: Revista Moín Moín: Revista de estudos sobre teatro de formas animadas - UDESC e Sociedade Cultural Artística de Jaraguá do Sul, ano 1, no 1;

Cuenca, M. C. (2009). Más allá del trabajo: el ocio de los jubilados. Revista MalEstar e Subjetividade. Fortaleza: vol. 09, no 1, pp. 13-42;

Cuenca, M. C. (2009). Uma forma de entender el ocio. Bilbao: Universidad de Deusto, pp. 65-75;

Cuenca, M. C. \& Amigo, M. C. (2014). O encontro entre o ócio e a cultura: reflexões sobre o ócio criativo desde a investigação empírica. Do ócio: debates no contexto cultural contemporâneo. Coimbra: Grácio Ed; pp. 5-32;

Encarnação Reis, J. A. (1993). O riso estético segundo Bergson e Lalo. Revista Filosófica de Coimbra, no 4, vol. 2, pp. 313-368;

Engel, G. I. (2000). Pesquisa Ação. Educar, Curitiba, no 16, pp. 181-191;

Escosteguy, A. C. D. (1998). Uma introdução aos Estudos Culturais. Revista FAMECOS. Porto Alegre, no 9, pp. 87-97;

Faleiros, V. (2009). Envelhecimento no Brasil: desafios e compromissos. Envelhecimento e subjetividade: desafios para uma cultura de compromisso social. 1a edição, pp. 63-77;

Ferreira, M. N. (2006). Transição à reforma, qualidade de vida e envelhecimento. Revista transdisciplinar de gerontologia. Universidade Sênior Contemporânea, Porto, Ano I, vol. I, pp. 30-34;

Ferreira, P. M. (2015). O Envelhecimento ativo em Portugal: tendências recentes e (alguns) problemas. Revista Kairós Gerontologia, no 19, pp.07-29;

Franco, M. A. S. (2005). Pedagogia da Pesquisa-Ação. Educação e Pesquisa, São Paulo, v. 31, n. 3, pp. 483-502;

Galinha, I. \& Ribeiro, J. L. P. (2005). História e evolução do conceito de bem-estar subjetivo. Psicologia, Saúde \& Doenças. Porto: 6 (2), pp. 203-214;

Gomes, C. L. (2007). O "ócio" como objeto de estudos: notas introdutórias sobre conceitos e ocorrência histórica em nossa sociedade. Cuadernos de ocio y sociedad. v I, pp. $23-40$;

Gomes, M. S. A., Lessa, J. \& Sá, R. N. (2006). O papel do idoso nas dinâmicas sociais de realização do ser-no-mundo-com-o-outro. Revista transdisciplinar de gerontologia. Universidade Sênior Contemporânea, Porto, Ano I, vol. I, pp. 07-12;

Grunewald, V. (2006). Desenvolvendo a arte de ser na terceira idade. Revista transdisciplinar de gerontologia. Universidade Sênior Contemporânea, Porto, Ano I, vol. I, pp. 35-59;

Jardim, J. (2002). O ator transparente: reflexões sobre o treinamento contemporâneo do ator com a máscara do palhaço e do bufão. Revista Sala Preta. Ed. ECA/USP, São Paulo, n. 2, pp. 17-24;

Joia, L. C.; Ruiz, T. \& Donalísio, M. R. (2007). Condições associadas ao grau de satisfação com a vida entre a população de idosos. Revista Saúde Pública. 41 (1), pp. 131-138

Júnior, A. F. B. \& Júnior, N. F. (2011). A utilização da técnica de entrevista em trabalhos científicos. Evidência: Olhares e pesquisa em saberes educacionais. Araxá, n. 4, pp. 237-250;

Kasper, K. M. (2009). Experimentar, devir, contagiar: o que pode um corpo? Próposições, LUME. Campinas, v.20, n. 3 (60), pp. 199-213; 
Koudela, I. D. (2010). Apresentação do dossiê Jogos Teatrais no Brasil: 30 anos. Fênix: Revista de História e Estudos Culturais. Vol. 7, ano VII, no 1;

Kovács, M. J. (2009). Doença e morte no imaginário do homem velho. A Terceira Idade. São Paulo, v.20, n. 46, pp. 62-73;

Krafta, L., Freitas, H., Martens, C. \& Andres, R. O método da Pesquisa-Ação: um estudo em uma empresa de coleta e análise de dados. Revista Quanti \& Quali;

Lacerda, R. A. M. V. (2009). A qualidade de vida no processo de readaptação à vida na velhice: estudo com um grupo de homens acometidos de AVC. Inter Science Place, Revista Científica Internacional. Ano 2, no 6;

Martins, J. C. O. (2014). Tempo Livre, Ócio e Lazer: sobre palavras, conceitos e experiências. Do ócio: debates no contexto cultural contemporâneo. Coimbra: Grácio Ed; pp. 103-114;

Martins, J. C. O. \& Ponte, F. T. (2010). A experiência de ócio na sociedade de tempos escassos. Fortaleza: Revista Humanidades, v. 25, no 1, pp. 78-87;

Martins, J. L. (2015). Os Estudos Culturais como novas humanidades. Revista Lusófona de Estudos Culturais, v. 03, nำ1, pp. 341-361;

Monteagudo, M. J., Cuenca, J., Bayón, F. \& Kleiber, D. A. (2014). Ócio ao longo da vida: as potencialidades dos itinerários de ócio para a promoção do desenvolvimento humano. Do ócio: debates no contexto cultural contemporâneo. Coimbra: Grácio Ed; pp. 135-149;

Moragas, R. M. (2004). As relações intergeracionais nas sociedades contemporáneas. A Terceira Idade. São Paulo, v.15, n. 29, pp. 7-27;

Mendes, M. (2008). Movimentos anti-estresse: a vida na terceira idade. In: Encontro paranaense, Congresso Brasileiro, Convenção Brasil/latinoamericana, XIII, VIII, II. Curitiba: Centro Reichiano;

Neri, A. L. (2009). Saúde e envelhecimento: prevenção e promoção: as necessidades afetivas dos idosos. Envelhecimento e subjetividade: desafios para uma cultura de compromisso social. 1ª edição, pp. 103-110;

Nunes, D. (2010). Um outro olhar ao Medievo: o humor como objeto de estudos. Revista Alétheia de Estudos sobre Antiguidade e Medievo, v 2/2, pp. 01-14;

Ortiz, R. (2004). Estudos Culturais. Tempo Social. Universidade de São Paulo USP, pp. 119-127;

Paz, J. F. L. (2011). El proceso de envejecimiento, especialmente en las personas mayores, dinamizado por valores asociados al encuentro intergeneracional. Fortaleza: Revista Mal-Estar e Subjetividade, vol. 11, no 1, pp. 13-38;

Pedrosa, M. R. \& Tavares, H. M. (2009). Expressão corporal e educação: elos de conhecimento. Uberlândia: Revista da Católica, vol. 1, no 2, pp. 198-206;

Pinheiro, K. F., Rhoden, I. \& Martins, J. C. O. (2010). A experiência de ócio na sociedade hipermoderna. Fortaleza: Revista Mal-Estar e Subjetividade, v. 10, no 4;

Prado, S. D. \& Sayd, J. D. (2006). A gerontologia como campo do conhecimento: conceitos, interesses e projeto político. Ciência \& Saúde Coletiva. 11(2): pp. 491-501;

Puccetti, R. (1998). O riso em três tempos. Revista do LUME, № 01. Campinas: Ed. Unicamp, pp. 67-74;

Puccetti, R. (2009). No caminho do palhaço. Revista do LUME, no 07. Campinas: Ed. Unicamp, pp. 119-125; 
Resende, M. C. \& Neri, A. L. (2009). Ajustamento Psicológico e Perspectiva de Velhice Pessoal em Adultos com Deficiência Física. Psicologia em Estudo. Maringá: v. 14, n. 4, pp. 767-776;

Rhoden, I. (2014). Atributos das experiências de ócio e implicações contraditórias decorrentes do estilo de vida contemporâneo. Do ócio: debates no contexto cultural contemporâneo. Coimbra: Grácio Ed; pp. 63-74;

Ryff, C. D. (1989). Happiness is everything, or is it? Explorations on the meaning of psychological well being. Journal of Personality and Social Psychology, 57, 1069-1081;

Ribeiro, E. A. (2008). A perspectiva da entrevista na investigação qualitativa. Evidência: Olhares e pesquisa em saberes educacionais. Araxá, n. 4, pp. 129-148;

Schneider, R. H. \& Irigaray, T. Q. (2008). O envelhecimento na atualidade: aspectos cronológicos, biológicos, psicológicos e sociais. Estudos de Psicologia. Campinas: 25(4), pp. 585-593;

Silva, A. H. \& Fossá, M. I. (2013). Análise de conteúdo: Exemplo de aplicação da técnica para análise de dados qualitativos. IV Encontro de Ensino e Pesquisa em Administração e Contabilidade. Brasília: EnEPO;

Silva, L. R. F. (2008). Da velhice à terceira idade: o percurso histórico das identidades atreladas ao processo de envelhecimento. História, Ciências, Saúde - Manguinhos, Rio de Janeiro, Vol.15, n.1, pp.155-168;

Siqueira, M. M. M. \& Padovam, V. A. R. (2008). Bases teóricas de bem-estar subjetivo, bem-estar psicológico e bem-estar no trabalho. Psicologia: Teoria e Pesquisa, Brasília, Vol. 24 n. 2, pp. 201-209;

Tavares, B. M. M. (2008). O riso dos anjos e o riso dos demônios, consideração sobre o humor na obra de Milan Kundera. Cardernos de Letras da UFF. Dossie: Literatura e humor, 끄 37, pp. 35-49;

Tejera, D.B. O., Sousa, I. R. C. \& Sampaio, T. M. V. As relações de gênero na opção de lazer de pessoas atuantes em cooperativas de trabalho. Licere, Belo Horizonte, Vol. 06 n. 4. pp. 1-17;

WLRA. World Leisure and Recreation Association (1994). International Charter for Leisure Education. Revista ELRA (European Leisure and Recreation Association). Summer, pp. 13-16. 


\section{ANEXO 1}

\section{Tem mais de 65 anos de idade? Venha fazer TEATRO}

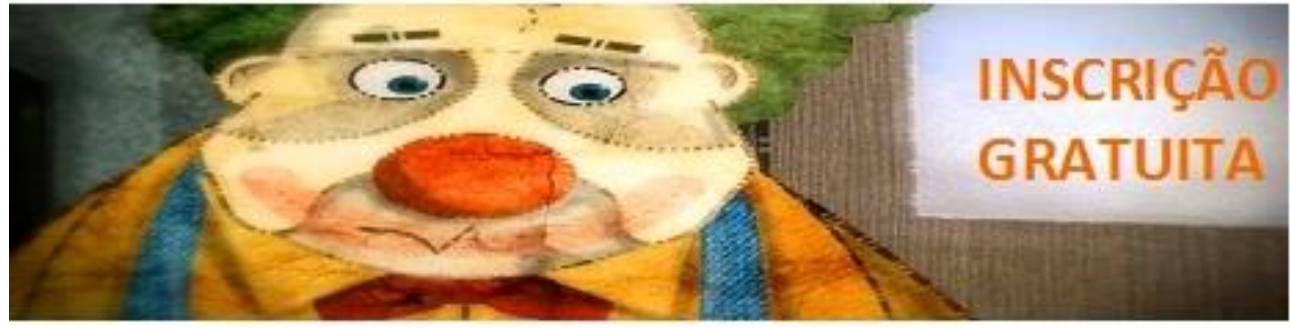

Faça parte do Programa: HUMOR E BEM-ESTAR NA VELHICE

PERÍODO: 01 de ABRIL a 30 de SETEMBRO de 2014

DIAS E HORÁRIOS: todas as TERÇAS-FEIRAS das 14 às $17 \mathrm{hs}$

\section{Processo \\ de \\ criação \\ do \\ PALHAÇO}

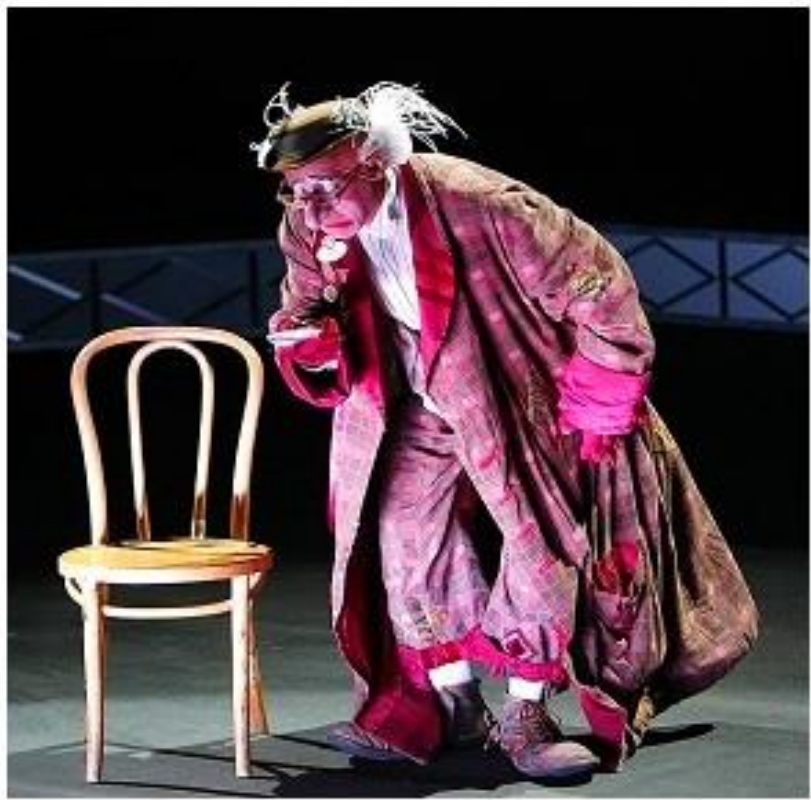

LOCAL: "CENTRO DE CONVÍVIO PARA IDOSOS DO BONFIM" Rua do Heroísmo, no 113 - Bonfim - Porto Telefone: 225194506

PROF: Klaas Kleber

APOIO:
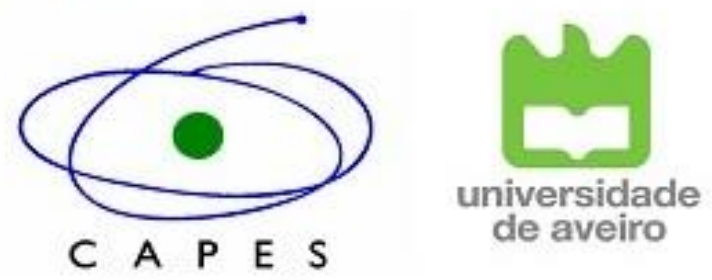


\section{ANEXO 2 \\ Termo de Consentimento Livre e Esclarecido - TCLE}

Convidamos o (a) $\mathrm{Sr}(\mathrm{a})$ a participar do programa "Humor e Bem-estar na Velhice", sob a responsabilidade do pesquisador Kleber José dos Santos, aluno do Programa Doutoral em Estudos Culturais do Departamento de Linguas e Culturas da Universidade de Aveiro (UA).

Sua participação é voluntária e se dará por meio de um processo de criação do clown, que decorrerá através da aplicação de um conjunto de atividades, como: preparação corporal, expressão corporal, jogos lúdicos, jogos teatrais e exercícios clássicos de clown (palhaço).

Se o (a) Sr (a) aceitar participar do programa, estará contribuindo para a construção de um saber acerca de questões relacionadas ao envelhecimento.

Se depois de consentir em sua participação o (a) $\mathrm{Sr}$ (a) desistir de continuar participando, tem o direito e a liberdade de retirar seu consentimento em qualquer fase da pesquisa, independente do motivo e sem nenhum prejuízo à sua pessoa. $\mathrm{O}$ (a) $\mathrm{Sr}$ (a) não terá nenhuma despesa e também não receberá nenhuma remuneração.

Os resultados da pesquisa serão analisados e publicados, mas sua identidade não será divulgada, sendo guardada em sigilo. Solicitamos somente a sua colaboração no sentido de autorizar a divulgação de imagens fotográficas.

Para qualquer outra informação, o (a) Sr (a) poderá entrar em contato com o pesquisador através do e-mail klaaskleber@gmail.com ou pelo telefone 916079525, ou poderá entrar em contato com o Comitê de Ética em Pesquisa dessa universidade.

Consentimento Pós-Informação:

$\mathrm{Eu}$, portador (a) do documento de identidade $\mathrm{n}^{\mathrm{o}}$ fui informado (a) sobre os objetivos do programa e sobre a importância da minha colaboração. Por isso, eu concordo em participar do programa Humor e Bem-estar na Velhice, e autorizo a divulgação das minhas imagens na forma citada acima.

Este documento é emitido em duas vias que serão ambas assinadas por mim e pelo pesquisador, ficando uma via com cada um de nós.

Data: /2014

Assinatura do participante

Assinatura do pesquisador responsável 


\section{ANEXO 3}

Ficha de dados sociodemográficos

\section{Ficha de documentação}

Informações sobre a entrevista e o entrevistado

\section{Entrevista}

Data: / / 2014

Local: Centro de Convívio para Idosos do Bonfim (CCIB)

Duração:

Investigador: Kleber José dos Santos

Entrevistado

Nome do entrevistado:

Sexo: $M(） F($ Idade:

Grau de escolaridade: Profissão:

Estado civil: $\quad$ № de Filhos: № de Netos: № de Bisnetos:

Reformado (a): $\operatorname{sim}($ ) não ( ) Tempo de reforma:

Particularidades ocorridas na entrevista: 


\section{ANEXO 4 \\ Roteiro de entrevista}

1- O (a) $\mathrm{Sr}$ (a) poderia nos dizer que idade tem hoje e com que idade atingiu a reforma?

2- No decorrer da vida, até o momento da reforma, além daqueles afazeres normais do dia-a-dia ou do trabalho, que tipo de atividades o (a) $\mathrm{Sr}$ (a) chegou a participar?

3- O (a) $\mathrm{Sr}$ (a) tem se sentido contente ou satisfeito (a) com a sua vida pessoal depois da reforma? Porque?

4- De tudo aquilo que o (a) $\mathrm{Sr}$ (a) faz atualmente em sua vida o que considera mais importante?

5- Para o (a) Sr (a), suas "horas vagas" têm sido ocupadas ou preenchidas de forma interessante ou satisfatória?

6- Quando está sozinho (a), que atividades o (a) Sr (a) costuma praticar como forma de lazer ou divertimento?

7- Que atividades o (a) Sr (a) realiza junto da família? Junto dos amigos? $\mathrm{Na}$ comunidade onde vive?

8- De todas essas atividades qual lhe dá mais prazer em praticar? Por quê?

9- Existe alguma atividade que $\mathrm{o}$ (a) $\mathrm{Sr}$ (a) nunca tivesse experimentado e quisesse praticar? Qual?

10- O (a) $\mathrm{Sr}$ (a) já participou de alguma atividade ligada a processos de criação, como teatro, dança, música, artes plásticas, literatura, artesanato ou folclore? Quais?

11- Com qual destas práticas de criação o (a) $\mathrm{Sr}$ (a) mais se identificou? Porque?

12- Com relação à atividade proposta, criação e elaboração do palhaço, o que motivou o (a) $\mathrm{Sr}($ a) a participar?

13- O (a) Sr (a) tem lembranças da primeira vez que viu um palhaço? Saberia dizer que idade tinha e onde foi?

14- Para o (a) $\mathrm{Sr}$ (a) o que o palhaço representa?

15- Na opinião do (a) Sr (a) que benefícios uma atividade como esta, a de criação e elaboração do palhaço, pode the oferecer? 